Supporting Information

For

\title{
Neopentyl Esters as Robust Linkers for Introducing Functionality to
}

\section{Bis-MPA Dendrimers}

Billy Deng, ${ }^{a}$ Stuart A. McNelles, ${ }^{a}$ Giancarlo Da-Ré, ${ }^{\text {a } V i c t o r i a ~ M . ~ M a r a n d o, ~}{ }^{\mathrm{a}, \mathrm{b}}$ Samantha Ros, ${ }^{\mathrm{a}}$ Harald D.

H. Stover, ${ }^{\text {a Alex Adronov }}{ }^{\text {** }}$

aDepartment of Chemistry \& Chemical Biology and the Brockhouse Institute for Materials Research, McMaster University, 1280 Main Street West, Hamilton, Ontario, Canada, L8S 4M1

${ }^{\mathrm{b}}$ Current Address: Department of Chemistry, Massachusetts Institute of Technology, Cambridge, MA 02139 


\section{Table of Contents}

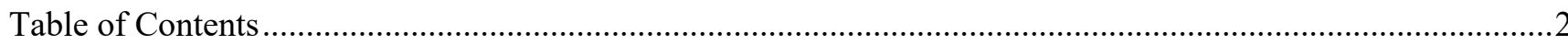

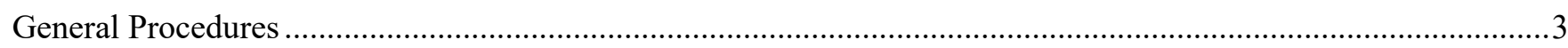

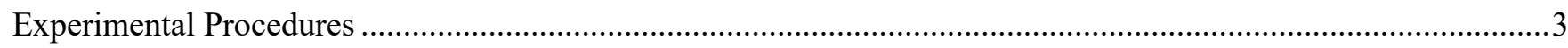

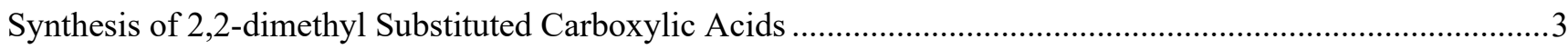

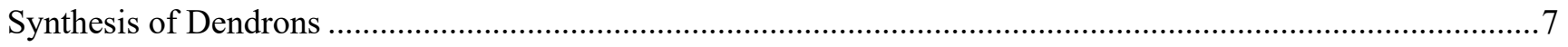

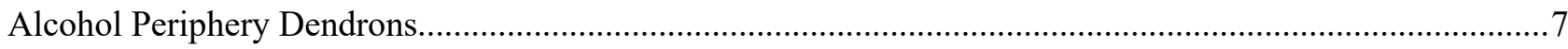

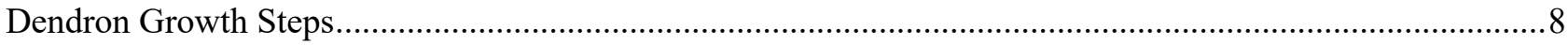

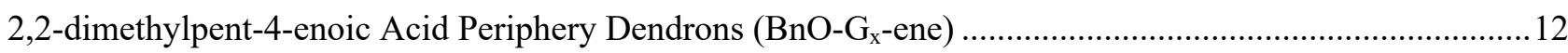

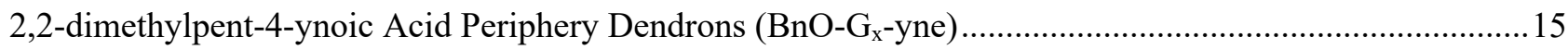

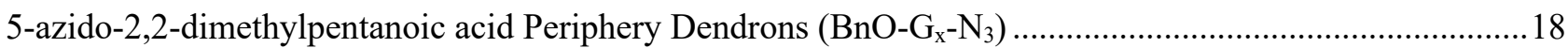

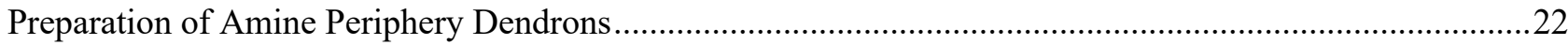

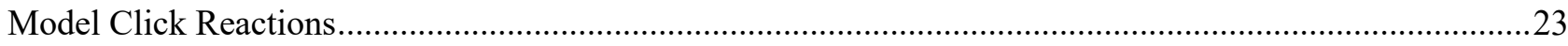

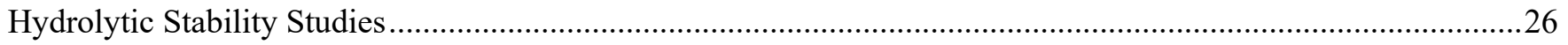

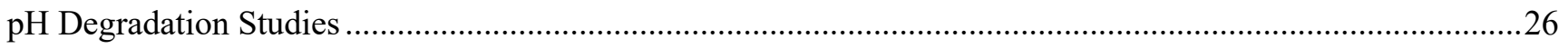

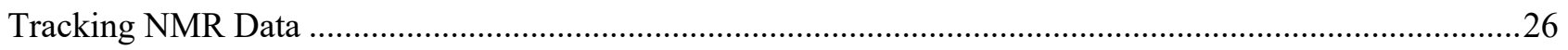

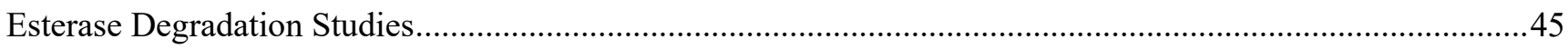

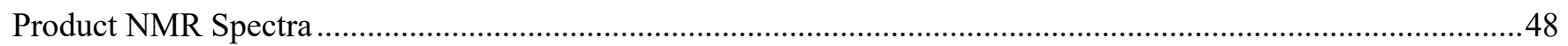

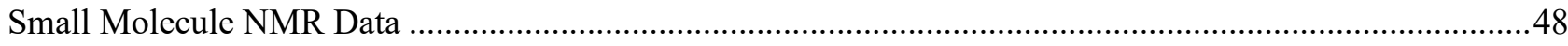

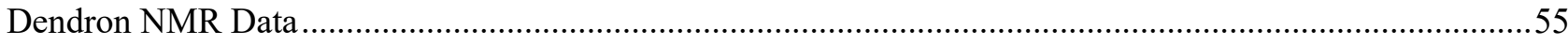

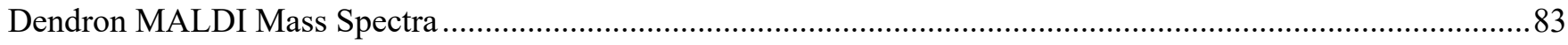

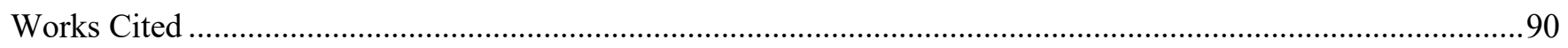




\section{General Procedures}

Unless stated otherwise, all chemicals were purchased from Sigma-Aldrich and used without further purification. THF was dried through a column of activated neutral alumina. ${ }^{1} \mathrm{H}$ NMR spectroscopy was performed on a Bruker Avance AV600 at $600 \mathrm{MHz} .{ }^{13} \mathrm{C}$ NMR spectroscopy was performed either on a Bruker Avance AV600 at $151 \mathrm{MHz}$ or Bruker Avance AV700 at $176 \mathrm{MHz}$. All chemical shifts are reported in ppm. All MALDI mass spectra were collected on a Bruker UltraFlextreme spectrometer in positive ion mode using either dithranol or sinapic acid as matrix. Electrospray MS was performed using a Micromass Quattro triple quadrupole instrument in positive mode. Exact masses were collected on either an Agilent 6210 TOF or a Bruker Maxis II Q-TOF. Flash chromatography was performed using an AnaLogix Intelliflash 280 automated flash chromatography system, equipped with a variable wavelength (200-320 nm) UV detector. Sorbtech screwtop flash columns packed with Silicycle R60 20$45 \mu \mathrm{m}$ silica gel were used as chromatography media.

\section{Experimental Procedures}

\section{Synthesis of 2,2-dimethyl Substituted Carboxylic Acids}

\section{Ethyl 2,2-dimethylpent-4-enoate}

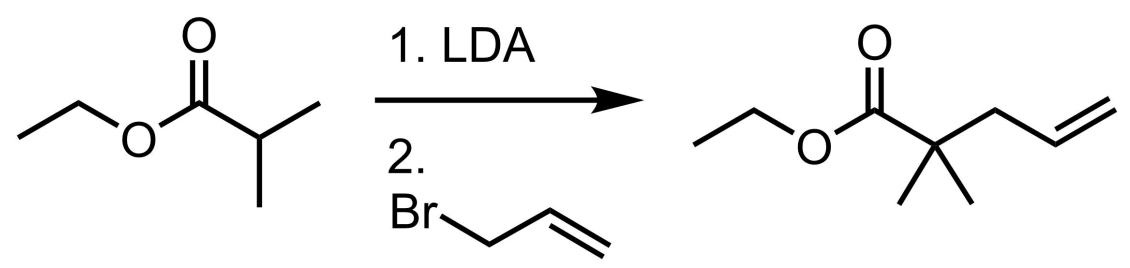

To a flame dried $250 \mathrm{~mL}$ Schlenk flask equipped with a magnetic stir bar and placed under nitrogen, diisopropylamine $(7.29 \mathrm{~mL}, 51.6 \mathrm{mmol})$ dissolved in $120 \mathrm{~mL}$ of dry THF was added. The solution was cooled to $78{ }^{\circ} \mathrm{C}$ and a solution of $2.5 \mathrm{M} n$-butyllithium in hexanes $(19.8 \mathrm{~mL}, 49.5 \mathrm{mmol})$ was then added dropwise via syringe over 2 minutes, resulting in a clear colourless solution. Separately, ethyl isobutyrate $(5.00 \mathrm{~g}, 43.1 \mathrm{mmol})$ was dissolved in $25 \mathrm{~mL}$ of THF and cooled to $-78^{\circ} \mathrm{C}$. This was then cannulated dropwise into the stirred solution of LDA and stirred for 30 minutes at $-78^{\circ} \mathrm{C}$ before allyl bromide $(5.59 \mathrm{~mL}, 65.6 \mathrm{mmol})$ was added in one portion. The 
solution was left to stir at $-78{ }^{\circ} \mathrm{C}$ for 2 hours, followed by addition of $100 \mathrm{~mL}$ of water to quench. The reaction mixture was diluted with $300 \mathrm{~mL}$ of diethyl ether, then washed with $3 \times 100 \mathrm{~mL} 1 \mathrm{M} \mathrm{HCl}, 1 \times 150 \mathrm{~mL}$ brine, and dried over $\mathrm{MgSO}_{4}$. The solvent was removed by rotary evaporation to give the crude product as a yellow oil. The crude product was purified by flash chromatography using a 50-g silica gel silica gel column equilibrated in hexanes. The product was eluted with $100 \%$ hexanes followed by $5 \%$ ether in hexanes over 5 column volumes. The product fractions were then pooled and dried by rotary evaporation to give the product as a clear, colourless oil. (5.671 g, $83 \%){ }^{1} \mathrm{H}$ NMR $\left(700 \mathrm{MHz} ; \mathrm{CDCl}_{3}\right)^{1}: \delta 5.76-5.70(\mathrm{~m}, 1 \mathrm{H}), 5.05(\mathrm{t}, J=0.9,1 \mathrm{H}), 5.04-5.02(\mathrm{~m}, 1 \mathrm{H}), 4.11(\mathrm{q}, J=7.1$, 2H), $2.27(\mathrm{dt}, J=7.4,1.1,2 \mathrm{H}), 1.24(\mathrm{t}, J=7.1,3 \mathrm{H}), 1.16(\mathrm{~s}, 6 \mathrm{H})$.

\section{2,2-dimethylpent-4-enoic acid (1)}

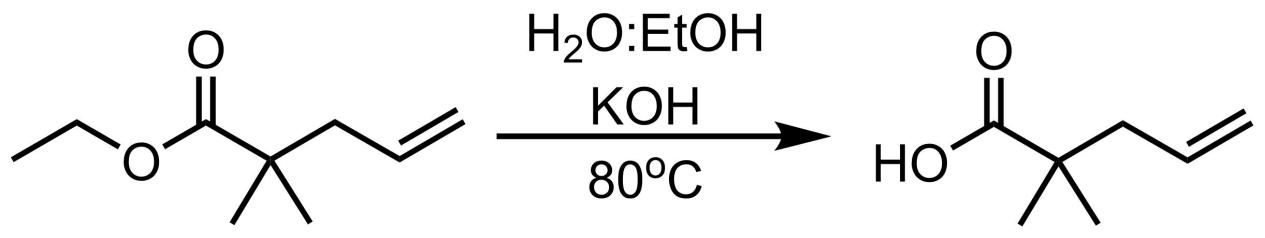

To a $100 \mathrm{~mL}$ round-bottomed flask equipped with a magnetic stir bar was added ethyl 2,2-dimethylpent-4-enoate (3.004 g, $19.3 \mathrm{mmol})$ and $50 \mathrm{~mL}$ of 2:1 EtOH:water, followed by potassium hydroxide (10.8 g, $192.6 \mathrm{mmol})$. The mixture was stirred at $80^{\circ} \mathrm{C}$ for 2 hours then left to cool to room temperature. The mixture was diluted with 100 $\mathrm{mL}$ of water, $100 \mathrm{~mL}$ of $1 \mathrm{M} \mathrm{H}_{3} \mathrm{PO}_{4}$, and extracted with $3 \times 100 \mathrm{~mL}$ of ether. The combined organic layers were washed with $1 \times 150 \mathrm{~mL}$ brine and dried over $\mathrm{MgSO}_{4}$. The solvent was removed by rotary evaporation to give the product as a slightly yellow oil. (1.996 g, 81\%) ${ }^{1} \mathrm{H}$ NMR $\left(700 \mathrm{MHz} ; \mathrm{CDCl}_{3}\right)^{2}: \delta 5.80-5.74(\mathrm{~m}, 1 \mathrm{H})$, 5.09-5.07 (m, $2 \mathrm{H}), 2.30(\mathrm{~d}, J=7.4,2 \mathrm{H}), 1.20(\mathrm{~s}, 6 \mathrm{H})$.

\section{Ethyl 2,2-dimethylpent-4-ynoate}

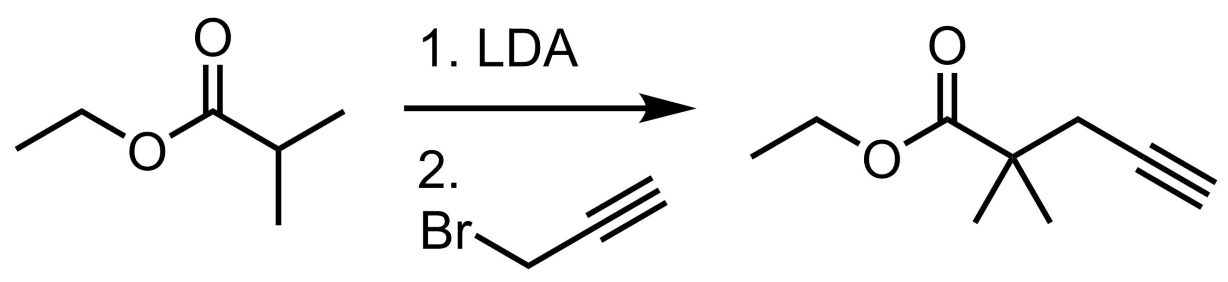


To a flame dried $250 \mathrm{~mL}$ Schlenk flask equipped with a magnetic stir-bar and placed under nitrogen was added diisopropylamine $(7.29 \mathrm{~mL}, 51.6 \mathrm{mmol})$ dissolved in $120 \mathrm{~mL}$ of dry THF. The solution was cooled to $-78^{\circ} \mathrm{C}$ and left to stir for 10 minutes. To this, a solution of $2.5 \mathrm{M} n$-butyllithium in hexanes $(19.8 \mathrm{~mL}, 49.5 \mathrm{mmol})$ was added dropwise via syringe over 2 minutes, resulting in a clear colourless solution. Separately, ethyl isobutyrate (5.00 g, $43.044 \mathrm{mmol}$ ) was dissolved in $25 \mathrm{~mL}$ of THF and cooled to $-78^{\circ} \mathrm{C}$. This was then cannulated dropwise into the stirred solution of LDA and left for 30 minutes at $-78{ }^{\circ} \mathrm{C}$ before an $80 \%$ solution of propargyl bromide in toluene (3.43 mL, $45.2 \mathrm{mmol}$ ) was added in one portion. This was stirred at $-78^{\circ} \mathrm{C}$ for 2 hours then quenched by adding $100 \mathrm{~mL}$ of water. The quenched reaction mixture was warmed to room temperature, then diluted with $300 \mathrm{~mL}$ hexanes and washed with $3 \times 100 \mathrm{~mL}$ of $1 \mathrm{M} \mathrm{H}_{3} \mathrm{PO}_{4}, 1 \times 150 \mathrm{~mL}$ brine, then dried over $\mathrm{MgSO}_{4}$. The solvent was removed by rotary evaporation to give the crude product as a yellow oil. This was purified by flash chromatography using a 50 gram silica gel column equilibrated in hexanes. The product was eluted with $100 \%$ hexanes followed by $5 \%$ ether in hexanes over 5 column volumes. The product-containing fractions were then pooled and dried by rotary evaporation to give the product as a clear, colourless oil. $(5.78 \mathrm{~g}, 88 \%){ }^{1} \mathrm{H} \mathrm{NMR}\left(600 \mathrm{MHz}, \mathrm{CDCl}_{3}\right)^{3} \delta 4.09(\mathrm{q}, J=$ 7.1, 2H), $2.38(\mathrm{~d}, J=2.7,2 \mathrm{H}), 1.95(\mathrm{t}, J=2.6,1 \mathrm{H}), 1.23-1.17(\mathrm{~m}, 5 \mathrm{H})$.

\section{2,2-dimethylpent-4-ynoic acid (2)}

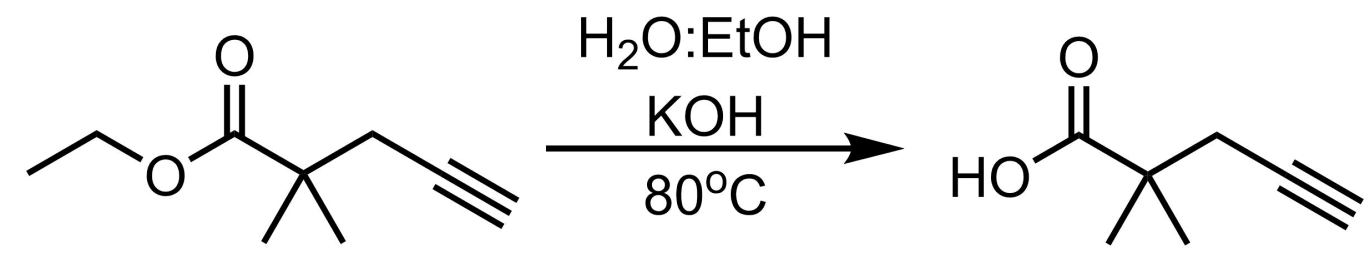

To a $100 \mathrm{~mL}$ round-bottomed flask equipped with a magnetic stir bar was added ethyl 2,2-dimethylpent-4-ynoate $(2.503 \mathrm{~g}, 16.25 \mathrm{mmol})$ and $50 \mathrm{~mL}$ of 2:1 EtOH:water, followed by potassium hydroxide $(9.107 \mathrm{~g}, 162.5 \mathrm{mmol})$. The mixture was stirred at $80^{\circ} \mathrm{C}$ for 2 hours, then left to cool to room temperature. The mixture was diluted with $100 \mathrm{~mL}$ of water and $100 \mathrm{~mL}$ of $1 \mathrm{M} \mathrm{H}_{3} \mathrm{PO}_{4}$ and extracted with $3 \times 100 \mathrm{~mL}$ of ether. The pooled organic layer was washed with $1 \times 150 \mathrm{~mL}$ brine and dried over $\mathrm{MgSO}_{4}$, and solvent was removed by rotary evaporation to give the product as a slightly yellow oil (1.984 g, 97\%). ${ }^{1} \mathrm{H}$ NMR $\left(500 \mathrm{MHz}, \mathrm{CDCl}_{3}\right)^{3} \delta 2.46(\mathrm{~d}, J=2.69,2 \mathrm{H}) 2.03(\mathrm{t}, 1 \mathrm{H})$, $1.31(\mathrm{~s}, 6 \mathrm{H})$. 


\section{Ethyl 5-chloro-2,2-dimethylpentanoate}

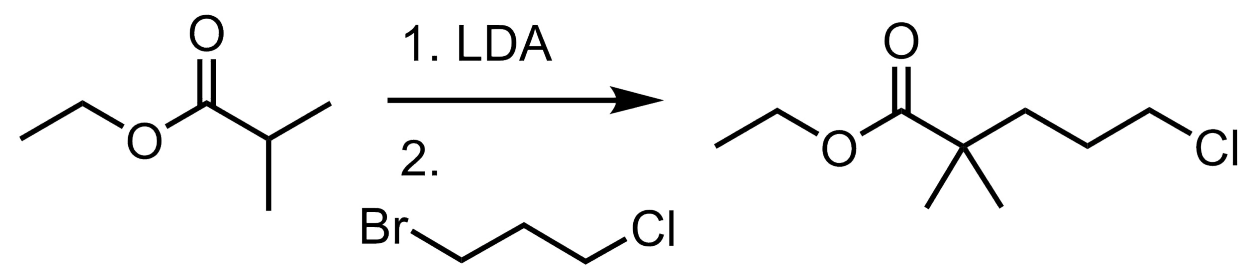

To a flame dried $250 \mathrm{~mL}$ Schlenk flask equipped with a magnetic stir bar and placed under nitrogen, diisopropylamine $(7.29 \mathrm{~mL}, 51.6 \mathrm{mmol})$ was added via syringe, and $120 \mathrm{~mL}$ of dry THF was added via cannula. The solution was cooled to $-78^{\circ} \mathrm{C}$ in a dry ice/acetone bath and this was left to cool for 10 minutes with stirring. To this, a solution of $2.5 \mathrm{M} n$-butyllithium in hexanes $(19.8 \mathrm{~mL})$ was added via syringe over two minutes, resulting in a clear colourless solution of LDA in THF. Separately, ethyl isobutyrate ( $5.00 \mathrm{~g}, 43.1 \mathrm{mmol})$ was dissolved in 25 $\mathrm{mL}$ of THF and cooled to $-78{ }^{\circ} \mathrm{C}$ in a dry ice/acetone bath. This was then cannulated dropwise into the stirred solution of LDA, then left for 30 minutes at $-78^{\circ} \mathrm{C}$ before 3-chloro-1-bromopropane $(6.385 \mathrm{~mL}, 64.6 \mathrm{mmol})$ was added as a neat liquid via syringe. This was left to react at $-78{ }^{\circ} \mathrm{C}$ for 30 minutes, then the reaction mixture was warmed to room temperature and left to stir for 3 hours. The reaction was then quenched by the addition of $50 \mathrm{~mL}$ of water, then diluted with $300 \mathrm{~mL}$ of diethyl ether and washed with $3 \times 100 \mathrm{~mL} 1 \mathrm{M} \mathrm{HCl}, 1 \times 150 \mathrm{~mL}$ brine, dried over $\mathrm{MgSO}_{4}$, filtered, and solvent was removed by rotary evaporation to give the crude product as a yellow oil. This was purified by flash chromatography using a 50 g silica gel column equilibrated in hexanes and elution with 5 column volumes of hexanes, then a gradient from $0 \%$ to $12 \%$ ether in hexanes over 20 column volumes. The fractions containing product were pooled and solvent was removed by rotary evaporation to give the product as a clear, colourless oil. (7.80 g, 94\%). ${ }^{1} \mathrm{H}$ NMR $\left(700 \mathrm{MHz}, \mathrm{CDCl}_{3}\right)^{4}: \delta 4.12(\mathrm{q}, J=7.1,2 \mathrm{H}), 3.50(\mathrm{t}, J=6.5,2 \mathrm{H}), 1.74-$ $1.70(\mathrm{~m}, 2 \mathrm{H}), 1.66-1.63(\mathrm{~m}, 2 \mathrm{H}), 1.24(\mathrm{t}, J=7.1,3 \mathrm{H}), 1.18(\mathrm{~s}, 6 \mathrm{H})$.

\section{Ethyl 5-azido-2,2-dimethylpentanoate}

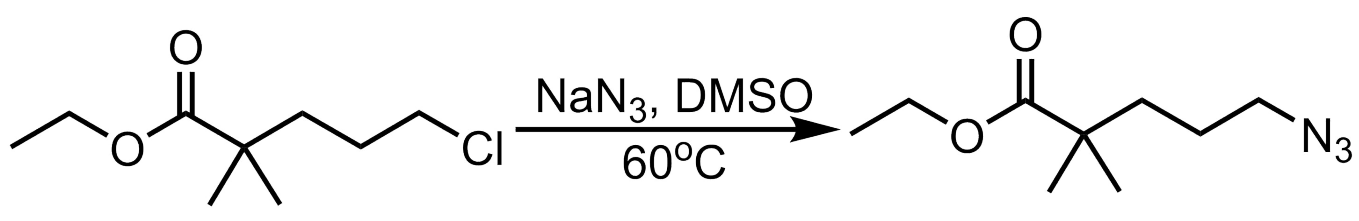


A $100 \mathrm{~mL}$ round-bottomed flask equipped with a magnetic stir bar was charged with a solution of sodium azide (3.373 g, $51.9 \mathrm{mmol})$ in $30 \mathrm{~mL}$ of DMSO, and to this ethyl 5-chloro-2,2-dimethylpentanoate (5.00 g, $25.95 \mathrm{mmol})$ was added. The solution was stirred and heated to $60{ }^{\circ} \mathrm{C}$ in an oil bath overnight, and the following day the reaction mixture was cooled to room temperature and diluted with $80 \mathrm{~mL}$ of water. This reaction mixture was then extracted with $3 \times 50 \mathrm{~mL}$ of ether, and the combined ether layers were washed with $1 \times 50 \mathrm{~mL}$ water, $1 \times 50 \mathrm{~mL}$ brine, dried over $\mathrm{MgSO}_{4}$, and solvent was removed by rotary evaporation to give the product as a clear, colourless oil. (5.16 g, 99\%) ${ }^{1} \mathrm{H}$ NMR $\left(700 \mathrm{MHz} ; \mathrm{CDCl}_{3}\right): \delta 4.12(\mathrm{q}, J=7.1,2 \mathrm{H}), 3.25(\mathrm{t}, J=6.5,2 \mathrm{H}), 1.60-1.52(\mathrm{~m}, 4 \mathrm{H}), 1.25(\mathrm{t}, J=7.1$, 3H), $1.18(\mathrm{~s}, 6 \mathrm{H}) .{ }^{13} \mathrm{C} \mathrm{NMR}\left(176 \mathrm{MHz} ; \mathrm{CDCl}_{3}\right): \delta 177.6,60.5,51.9,42.0,37.7,25.3,24.7,14.4$.

\section{5-azido-2,2-dimethylpentanoic acid (3)}

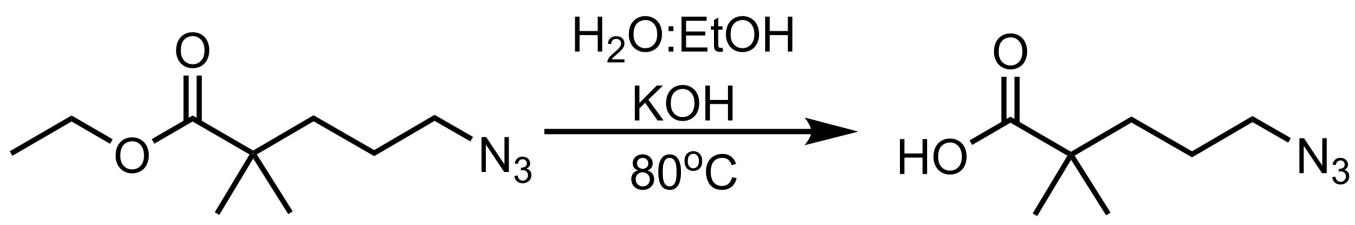

A $100 \mathrm{~mL}$ round-bottomed flask equipped with a magnetic stir bar was charged with ethyl 5-azido-2,2dimethylpentanoate $(5.12 \mathrm{~g}, 25.7 \mathrm{mmol})$ dissolved in $50 \mathrm{~mL}$ of 2:1 EtOH:water, followed by addition of potassium hydroxide $(7.20 \mathrm{~g}, 128.5 \mathrm{mmol})$. The reaction mixture was heated to $80{ }^{\circ} \mathrm{C}$ for 2 hours, then left to cool to room temperature. The reaction mixture was then diluted with $100 \mathrm{~mL}$ of water and $200 \mathrm{~mL}^{\circ} \mathrm{H}_{3} \mathrm{PO}_{4}$, then washed with $3 \times 100 \mathrm{~mL}$ ether, and the combined ether layers were washed with $1 \times 150 \mathrm{~mL}$ brine, dried over $\mathrm{MgSO}_{4}$, filtered,

and solvent was removed by rotary evaporation to give the product as a yellow-orange oil. (4.22 g, 96\%). ${ }^{1} \mathrm{H}$ NMR $\left(700 \mathrm{MHz} ; \mathrm{CDCl}_{3}\right): \delta 3.27(\mathrm{t}, J=5.6,2 \mathrm{H}), 1.63-1.58(\mathrm{~m}, 4 \mathrm{H}), 1.22(\mathrm{~s}, 6 \mathrm{H}){ }^{13} \mathrm{C}$ NMR $\left(176 \mathrm{MHz} ; \mathrm{CDCl}_{3}\right): \delta 184.5$ $51.8,42.0,37.5,25.1,24.7$.

\section{Synthesis of Dendrons}

\section{Alcohol Periphery Dendrons}

The model alcohol periphery dendrons from generations 1-5 were prepared in a divergent methodology starting from bis-MPA. This carboxylic acid core was protected with benzyl bromide ("BnO”), and the dendrons were grown 
using fluoride promoted esterification using acetonide-protected bis-MPA according to procedures by Malkoch and co-workers (Figure S1). ${ }^{5}$

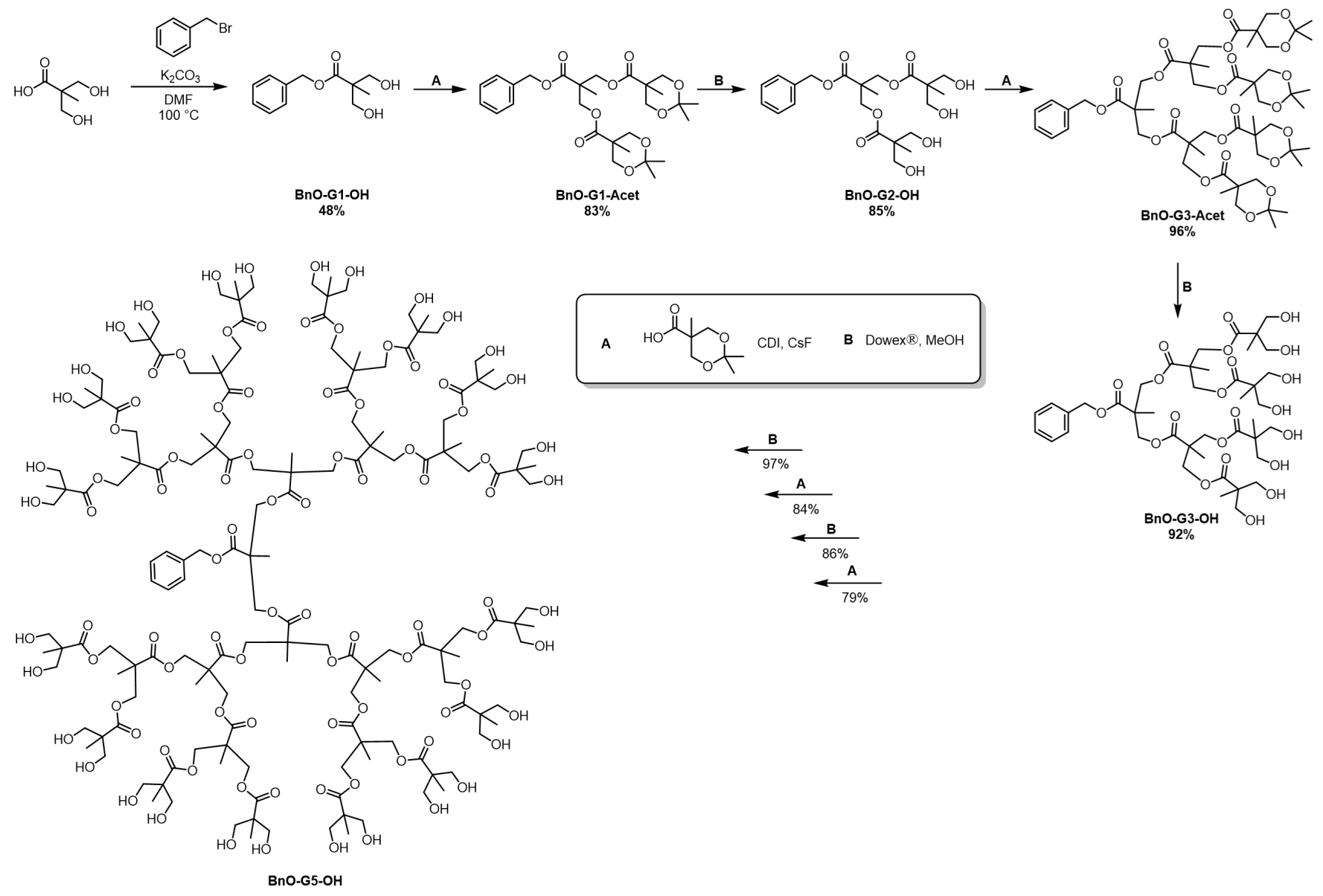

Figure S1. Preparation of G1-G5 benzyl core-protected hydroxyl periphery bis-MPA dendrons.

\section{Dendron Growth Steps}

\section{BnO-G1-OH}

A $100 \mathrm{~mL}$ round-bottomed flask equipped with a magnetic stir bar was charged with bis-MPA (9.00g, $67.11 \mathrm{mmol})$ dissolved in $50 \mathrm{~mL}$ of DMF, along with potassium hydroxide $(4.300 \mathrm{~g}, 76.64 \mathrm{mmol})$, and this was stirred and heated to $100{ }^{\circ} \mathrm{C}$ for 1 hour. At this point, benzyl bromide $(9.602 \mathrm{~mL}, 80.73 \mathrm{mmol})$ was added to the reaction mixture, which resulted in the formation of a white precipitate. This was left to heat for 16 hours, followed by removal of DMF via vacuum distillation. The resulting crude material was dissolved in $100 \mathrm{~mL}$ of DCM and washed with $3 \times$ $50 \mathrm{~mL}$ of water, $1 \times 50 \mathrm{~mL}$ brine, dried over $\mathrm{MgSO}_{4}$, filtered, and solvent was removed by rotary evaporation. The crude material was then recrystallized from 2:1 hexanes:DCM to give the product as clear, colourless needles $(7.22 \mathrm{~g}$, 
48 \%). ${ }^{1} \mathrm{H}$ NMR (600 MHz; $\left.\mathrm{CDCl}_{3}\right): \delta$ 7.39-7.32 (m, 5H), $5.22(\mathrm{~s}, 2 \mathrm{H}), 3.94(\mathrm{dd}, J=10.7,6.8,2 \mathrm{H}), 3.74(\mathrm{dd}, J=$ $11.4,6.4,2 \mathrm{H}), 2.76(\mathrm{t}, J=6.7,2 \mathrm{H}), 1.08(\mathrm{~s}, 3 \mathrm{H})$.

\section{BnO-G2-(Acet) ${ }_{4}{ }^{6}$}

A $100 \mathrm{~mL}$ round-bottomed flask equipped with a magnetic stir bar was charged with 1,1'-Carbonyldiimidazole $(9.61 \mathrm{~g}, 59.27 \mathrm{mmol})$ dissolved in $30 \mathrm{~mL}$ of EtOAc. The mixture was stirred and heated to $50{ }^{\circ} \mathrm{C}$. This solution was stirred rapidly while acetonide protected bis-MPA (10.34 g, $59.28 \mathrm{mmol})$ was added in small portions over 2 minutes, which resulted in the vigorous evolution of gas. This was left stirring at $50{ }^{\circ} \mathrm{C}$ for 1 hour, followed by addition of BnO-G1-OH (4.43 g, $19.76 \mathrm{mmol})$ and $\mathrm{CsF}(1.20 \mathrm{~g}, 8.90 \mathrm{mmol})$ in a single portion. After 4 hours the reaction was complete by TLC and was quenched with $5 \mathrm{~mL}$ of water for 1 hour, then diluted with $100 \mathrm{~mL}$ of EtOAc and washed with $3 \times 100 \mathrm{~mL}$ of $10 \% \mathrm{NaHCO}_{3}$ and $1 \times 100 \mathrm{~mL}$ brine, dried over $\mathrm{MgSO}_{4}$, filtered, and solvent was removed by rotary evaporation. The crude material was purified by chromatography using a 100 -gram silica gel silica gel column equilibrated in 5\% acetone:hexanes, and the material was purified using a gradient from $5 \%$ to $50 \%$ acetone:hexanes over 20 column volumes, with detection at $205 \mathrm{~nm}$. The fractions containing product were pooled and solvent was removed by rotary evaporation and the resulting oil was dried in vacuo to give the product as a viscous, colourless oil (8.78 g, 83\%). ${ }^{1} \mathrm{H}$ NMR (600 MHz; $\left.\mathrm{CDCl}_{3}\right): \delta$ 7.37-7.31 (m, 5H), $5.16(\mathrm{~s}, 2 \mathrm{H})$, 4.36-4.32 (m, 4H), $4.10(\mathrm{~d}, J=11.8,4 \mathrm{H}), 3.58(\mathrm{~d}, J=11.4,4 \mathrm{H}), 1.41(\mathrm{~s}, 6 \mathrm{H}), 1.34(\mathrm{~s}, 6 \mathrm{H}), 1.30(\mathrm{~s}, 3 \mathrm{H}), 1.10(\mathrm{~s}$, $6 \mathrm{H})$.

\section{BnO-G2-(OH) ${ }^{6}$}

A $100 \mathrm{~mL}$ round-bottomed flask equipped with a magnetic stir bar was charged with BnO-G2-Acet (2.15 g, 4.001 mmol) dissolved in $45 \mathrm{~mL}$ of EtOH, then 1 scoopula full of DOWEX beads was added and the solution was stirred for 3 hours at room temperature and monitored by ESI-MS. Once complete deprotection was observed, the solution was filtered through a glass frit to recover the DOWEX, and the filtrate was dried by rotary evaporation then in vacuo overnight to give the product as a sticky white powder (1.54 g, 85\%) ${ }^{1} \mathrm{H}$ NMR (600 MHz; MeOD): $\delta 7.40-$ $7.31(\mathrm{~m}, 5 \mathrm{H}), 5.18(\mathrm{~s}, 2 \mathrm{H}), 4.29(\mathrm{q}, J=9.0,4 \mathrm{H}), 3.63(\mathrm{dd}, J=10.8,5.6,4 \mathrm{H}), 3.57(\mathrm{~d}, J=10.8,4 \mathrm{H}), 1.30(\mathrm{~s}, 3 \mathrm{H})$, $1.09(\mathrm{~s}, 6 \mathrm{H})$ 


\section{BnO-G3-(Acet) ${ }_{4}{ }^{6}$}

A $100 \mathrm{~mL}$ round-bottomed flask equipped with a magnetic stir bar was charged with 1,1'-carbonyldiimidazole (4.26 g, $26.30 \mathrm{mmol}$ ) and $20 \mathrm{~mL}$ of EtOAc, and the mixture was stirred and heated to $50{ }^{\circ} \mathrm{C}$. This suspension was stirred rapidly while acetonide protected bis-MPA $(4.74 \mathrm{~g}, 27.16 \mathrm{mmol})$ was added in small portions over 2 minutes, which resulted in the vigorous evolution of gas. This was left stirring at $50{ }^{\circ} \mathrm{C}$ for 1 hour, followed by addition of BnO$\mathrm{G} 2-(\mathrm{OH})_{4}(2.002 \mathrm{~g}, 4.381 \mathrm{mmol})$ and $\mathrm{CsF}(0.53 \mathrm{~g}, 3.51 \mathrm{mmol})$ in a single portion. After 4 hours the reaction was complete by TLC and was quenched with $5 \mathrm{~mL}$ of water for 1 hour, then diluted with $100 \mathrm{~mL}$ of EtOAc and washed with $3 \times 100 \mathrm{~mL}$ of $10 \% \mathrm{NaHCO}_{3}$ and $1 \times 100 \mathrm{~mL}$ brine, dried over $\mathrm{MgSO}_{4}$, filtered, and solvent was removed by rotary evaporation. The crude material was purified by chromatography using a $100 \mathrm{~g}$ silica gel silica gel column equilibrated in 5\% acetone:hexanes, and the material was purified using a gradient from 5\% to 50\% acetone:hexanes over 20 column volumes, with detection at $205 \mathrm{~nm}$. The fractions containing product were pooled and solvent was removed by rotary evaporation and the resulting oil was dried in vacuo to give the product as a viscous oil (4.570 g, 96\%). ${ }^{1} \mathrm{H}$ NMR (600 MHz; $\left.\mathrm{CDCl}_{3}\right): \delta$ 7.37-7.30 (m, 5H), $5.16(\mathrm{~s}, 2 \mathrm{H}), 4.30-4.23(\mathrm{~m}, 12 \mathrm{H}), 4.14(\mathrm{~d}, J=11.8$, $8 \mathrm{H}), 3.61(\mathrm{~d}, J=12.0,8 \mathrm{H}), 1.40(\mathrm{~s}, 12 \mathrm{H}), 1.34(\mathrm{~s}, 12 \mathrm{H}), 1.27(\mathrm{~s}, 3 \mathrm{H}), 1.19(\mathrm{~s}, 6 \mathrm{H}), 1.13(\mathrm{~s}, 12 \mathrm{H})$.

\section{BnO-G3-(OH)8 ${ }^{6}$}

A $100 \mathrm{~mL}$ round-bottomed flask equipped with a magnetic stir bar was charged with a solution of BnO-G3-(Acet) $(2.06 \mathrm{~g}, 1.91 \mathrm{mmol})$ in $45 \mathrm{~mL}$ of EtOH, then 1 scoopula full of DOWEX beads were added and the solution was stirred for 3 hours at room temperature, Once complete deprotection was observed by ESI-MS, This was filtered through a glass frit to recover the DOWEX, and the filtrate was dried by rotary evaporation then in vacuo overnight to give the product as a white powder. (1.62 g, 92\%) ${ }^{1} \mathrm{H}$ NMR (700 MHz; MeOD): $\delta 7.35(\mathrm{~d}, J=7.1,2 \mathrm{H}), 7.31(\mathrm{t}$, $J=7.4,2 \mathrm{H}), 7.27(\mathrm{t}, J=7.2,1 \mathrm{H}), 5.14(\mathrm{~s}, 2 \mathrm{H}), 4.27(\mathrm{~d}, J=11.0,2 \mathrm{H}), 4.22-4.19(\mathrm{~m}, 6 \mathrm{H}), 4.13(\mathrm{dd}, J=11.0,6.6$, 4H), $3.61(\mathrm{dd}, J=10.9,3.4,8 \mathrm{H}), 3.53(\mathrm{~d}, J=10.8,8 \mathrm{H}), 1.25(\mathrm{~s}, 3 \mathrm{H}), 1.14(\mathrm{~s}, 6 \mathrm{H}), 1.08(\mathrm{~s}, 12 \mathrm{H})$

\section{BnO-G4-(Acet) ${ }_{8}{ }^{6}$}

A $25 \mathrm{~mL}$ round-bottomed flask equipped with a magnetic stir bar was charged with a solution of 1,1'Carbonyldiimidazole $(2.11 \mathrm{~g}, 13.03 \mathrm{mmol})$ in $6.5 \mathrm{~mL}$ of EtOAc and heated to $50{ }^{\circ} \mathrm{C}$. This suspension was stirred 
rapidly while acetonide protected bis-MPA $(2.32 \mathrm{~g}, 13.29 \mathrm{mmol})$ was added in small portions over 2 minutes, which resulted in the vigorous evolution of gas. This was left to react for 1 hour, at which point BnO-G3-(OH) 8 (1.00 g, $1.086 \mathrm{mmol})$ was added, along with CsF (0.26 g, $1.74 \mathrm{mmol})$. After 6 hours the reaction was complete by ESI-MS and was quenched by the addition of $2 \mathrm{~mL}$ of water for 1 hour, then diluted with $100 \mathrm{~mL}$ of EtOAc and washed with $3 \times 100 \mathrm{~mL}$ of $10 \% \mathrm{NaHCO}_{3}$ and $1 \times 100 \mathrm{~mL}$ brine, dried over $\mathrm{MgSO}_{4}$, filtered, and solvent was removed by rotary evaporation. The crude material was purified by silica gel chromatography using a $25 \mathrm{~g}$ silica gel column equilibrated in 5\% acetone:hexanes, and the material was purified using a gradient from 5\% to 50\% acetone:hexanes over 20 column volumes, with detection at $205 \mathrm{~nm}$. The fractions containing product were pooled and solvent was removed by rotary evaporation. Solvent was removed in vacuo to give the product as a clear viscous oil. (1.86 g, 79\%) ${ }^{1} \mathrm{H}$ NMR (600 MHz; $\left.\mathrm{CDCl}_{3}\right): \delta 7.36-7.31(\mathrm{~m}, 5 \mathrm{H}), 5.15(\mathrm{~s}, 2 \mathrm{H}), 4.32-4.27(\mathrm{~m}, 18 \mathrm{H}), 4.22-4.18(\mathrm{~m}, 10 \mathrm{H}), 4.13$ $(\mathrm{d}, J=11.9,16 \mathrm{H}), 3.61(\mathrm{dd}, J=11.9,2.3,16 \mathrm{H}), 1.40(\mathrm{~s}, 24 \mathrm{H}), 1.34(\mathrm{~s}, 24 \mathrm{H}), 1.29(\mathrm{~s}, 3 \mathrm{H}), 1.26(\mathrm{~s}, 12 \mathrm{H}), 1.17(\mathrm{~s}$, $6 \mathrm{H}), 1.13(\mathrm{~s}, 24 \mathrm{H})$

\section{BnO-G4-(OH) $)^{6}$}

A $100 \mathrm{~mL}$ round-bottomed flask equipped with a magnetic stir bar was charged with BnO-G4-(acet) ${ }_{8}(1.50 \mathrm{~g}, 0.95$ mmol) dissolved in $45 \mathrm{~mL}$ of EtOH, followed by addition of 1 scoopula full of DOWEX beads and was left to stir for 6 hours and monitored by ESI-MS. This was filtered through a glass frit to recover the DOWEX, and the filtrate was dried by rotary evaporation then in vacuo overnight to give the product as a white powder. $(1.11 \mathrm{~g}, 86 \%){ }^{1} \mathrm{H}$ NMR (600 MHz, MeOD) $\delta 7.47-7.30(\mathrm{~m}, 5 \mathrm{H}), 5.22(\mathrm{~s}, 2 \mathrm{H}), 4.46-4.15(\mathrm{~m}, 28 \mathrm{H}), 3.67$ (dd, $J=10.9,3.3 \mathrm{~Hz}$ 15H), $3.60(\mathrm{~d}, J=10.9 \mathrm{~Hz}, 15 \mathrm{H}), 1.35(\mathrm{~s}, 3 \mathrm{H}), 1.29(\mathrm{~s}, 12 \mathrm{H}), 1.22(\mathrm{~s}, 6 \mathrm{H}), 1.15(\mathrm{~s}, 24 \mathrm{H})$.

\section{BnO-G5-(Acet) ${ }_{16}{ }^{6}$}

A $25 \mathrm{~mL}$ round-bottomed flask equipped with a magnetic stir bar was charged with 1,1'-Carbonyldiimidazole (1.36 g, $13.03 \mathrm{mmol}$ ) added to $5 \mathrm{~mL}$ of EtOAc and heated to $50^{\circ} \mathrm{C}$. This suspension was stirred rapidly while acetonide protected bis-MPA ( $1.99 \mathrm{~g}, 8.58 \mathrm{mmol})$ was added in small portions over 2 minutes, which resulted in the vigorous evolution of gas. This was left to react for 1 hour followed by addition of BnO-G4-(OH) 8 (640 mg, $0.346 \mathrm{mmol})$ and $\mathrm{CsF}(168.2 \mathrm{mg}, 1.11 \mathrm{mmol})$ in a single portion. After 6 hours the reaction was complete by ESI-MS and was quenched with $2 \mathrm{~mL}$ of water for 1 hour, then diluted with $100 \mathrm{~mL}$ of EtOAc and washed with $3 \times 100 \mathrm{~mL}$ of $10 \%$ 
$\mathrm{NaHCO}_{3}$ and $1 \times 100 \mathrm{~mL}$ brine, dried over $\mathrm{MgSO}_{4}$, filtered, and solvent was removed by rotary evaporation. The crude material was purified by silica gel chromatography using a 25 gram silica gel column equilibrated in 5\% acetone:hexanes, and the material was purified using a gradient from 5\% to 50\% acetone:hexanes over 20 column volumes, with detection at $205 \mathrm{~nm}$. The fractions containing product were pooled and solvent was removed by rotary evaporation and the resulting oil was dried in vacuo to give the product as a white solid $(1.26 \mathrm{~g}, 84 \%) .{ }^{1} \mathrm{H}$ NMR (600 MHz, $\left.\mathrm{CDCl}_{3}\right) \delta 7.39-7.29(\mathrm{~m}, 5 \mathrm{H}), 5.16(\mathrm{~s}, 2 \mathrm{H}), 4.07-4.42(\mathrm{~m}, 90 \mathrm{H}), 3.74-3.53(\mathrm{~m}, 32 \mathrm{H}), 1.41(\mathrm{~m}$, $45 \mathrm{H}), 1.34(\mathrm{~d}, J=1.7 \mathrm{~Hz}, 50 \mathrm{H}), 1.26(\mathrm{~m}, 36 \mathrm{H}), 1.13(\mathrm{~d}, J=2.1 \mathrm{~Hz}, 60 \mathrm{H})$.

\section{BnO-G5-(OH) $)_{32}^{6}$}

A $100 \mathrm{~mL}$ round-bottomed flask equipped with a magnetic stir bar was charged with BnO-G5-(acet) $)_{16}(400 \mathrm{mg}$, $0.092 \mathrm{mmol}$ ) dissolved in $25 \mathrm{~mL}$ of EtOH, then 1 scoopula full of DOWEX beads was added and the mixture was stirred for overnight at room temperature. This was filtered through a glass frit to recover the DOWEX, and the filtrate was dried by rotary evaporation then in vacuo overnight to give the product as a white powder (329 mg, 97\%). ${ }^{1} \mathrm{H}$ NMR (600 MHz, MeOD) $\delta 7.49-7.35$ (m, 5H), $5.26(\mathrm{~s}, 2 \mathrm{H}), 4.45-4.22(\mathrm{~m}, 60 \mathrm{H}), 3.70(\mathrm{dd}, J=10.9$, $2.9 \mathrm{~Hz}, 32 \mathrm{H}), 3.63(\mathrm{~d}, J=10.8 \mathrm{~Hz}, 32 \mathrm{H}), 1.36-1.26(\mathrm{~m}, 45 \mathrm{H}), 1.17(\mathrm{~s}, 48 \mathrm{H})$.

\section{2,2-dimethylpent-4-enoic Acid Periphery Dendrons (BnO-G (Bene) -ene BnO-G1-(ene)}

A $25 \mathrm{~mL}$ round-bottomed flask equipped with a magnetic stir bar was charged with 1,1 '-carbonyldiimidazole $(0.108$ g, $0.669 \mathrm{mmol}$ ) suspended in $0.33 \mathrm{~mL}$ of EtOAc and heated to $50{ }^{\circ} \mathrm{C}$. Compound $1(87 \mathrm{mg}, 0.682 \mathrm{mmol})$ was added dropwise and stirred for 1 hour. BnO-G1-(OH) $(50 \mathrm{mg}, 0.223 \mathrm{mmol})$ was added, along with $\mathrm{CsF}$ (14 mg, 0.089 mmol). The reaction progress was monitored by TLC ( $\sim 4$ hours) and quenched with $0.1 \mathrm{~mL}$ of water. The reaction mixture was extracted with, $3 \times 30 \mathrm{~mL}$ of $10 \% \mathrm{Na}_{2} \mathrm{CO}_{3}, 3 \times 30 \mathrm{~mL}$ of $1 \mathrm{M} \mathrm{H}_{3} \mathrm{PO}_{4}, 1 \times 50 \mathrm{~mL}$ brine, dried over $\mathrm{MgSO}_{4}$, filtered, and solvent was removed by rotary evaporation to give the crude product as a slightly yellow oil. The resulting material was purified by silica gel chromatography using a 12-gram silica gel column equilibrated in $2 \%$ acetone:hexanes, then eluted using a gradient from $2 \%$ to $20 \%$ acetone:hexanes over 20 column volumes and 
monitored at $205 \mathrm{~nm}$. The fractions containing product were pooled and solvent was removed by rotary evaporation and the resulting oil was dried in vacuo to give the product as a clear, colourless oil (73 mg, 74\%). ${ }^{1} \mathrm{H}$ NMR (600 $\left.\mathrm{MHz} ; \mathrm{CDCl}_{3}\right): \delta 7.37-7.31(\mathrm{~m}, 5 \mathrm{H}), 5.66(\mathrm{ddt}, J=17.0,10.1,7.2,2 \mathrm{H}), 5.15(\mathrm{~s}, 2 \mathrm{H}), 5.04-4.99(\mathrm{~m}, 4 \mathrm{H}), 4.24-4.20$ $(\mathrm{m}, 4 \mathrm{H}), 2.21(\mathrm{~d}, J=7.4,4 \mathrm{H}), 1.28(\mathrm{~s}, 3 \mathrm{H}), 1.11(\mathrm{~d}, J=1.5,12 \mathrm{H}) .{ }^{13} \mathrm{C} \mathrm{NMR}\left(176 \mathrm{MHz} ; \mathrm{CDCl}_{3}\right): \delta 176.9,172.7$ $135.6,134.0,128.8,128.5,128.3,118.3,67.0,65.6,46.7,44.7,42.6,24.8,18.1$. MALDI: $[\mathrm{M}]_{\text {calc: }} 444.3 \mathrm{Da}$ $[\mathrm{M}+\mathrm{Na}]^{+}{ }_{\text {found: }} 466.5 \mathrm{Da}$.

\section{BnO-G2-(ene) 4}

A $25 \mathrm{~mL}$ round-bottomed flask equipped with a magnetic stir bar was charged with 1,1'-carbonyldiimidazole $(0.108$ g, $0.669 \mathrm{mmol}$ ) suspended in $0.33 \mathrm{~mL}$ of EtOAc and heated to $50{ }^{\circ} \mathrm{C}$. Compound 1 ( $\left.87 \mathrm{mg}, 0.682 \mathrm{mmol}\right)$ was added dropwise and stirred for 1 hour. BnO-G1-(OH) $2(0.050 \mathrm{~g}, 0.223 \mathrm{mmol})$ and $\mathrm{CsF}(0.014 \mathrm{~g}, 0.089 \mathrm{mmol})$ was added in a single portion. The reaction progress was monitored by TLC ( $\sim 5$ hours) and then quenched by the addition of $0.1 \mathrm{~mL}$ of water. The reaction mixture was then extracted with, $3 \times 30 \mathrm{~mL}$ of $10 \% \mathrm{Na}_{2} \mathrm{CO}_{3}, 3 \times 30 \mathrm{~mL}$ of $1 \mathrm{M}$ $\mathrm{H}_{3} \mathrm{PO}_{4}, 1 \times 50 \mathrm{~mL}$ brine, dried over $\mathrm{MgSO}_{4}$, filtered, and solvent was removed by rotary evaporation to give the crude product as a slightly yellow oil. The resulting material was purified by silica gel chromatography using a 10gram silica gel column equilibrated in $2 \%$ acetone:hexanes, then eluted using a gradient from $2 \%$ to $20 \%$ acetone:hexanes over 20 column volumes and monitored at $205 \mathrm{~nm}$. The fractions containing product were pooled and solvent was removed by rotary evaporation and the resulting oil was dried in vacuo to give the product as a clear, colourless oil (73 mg, 74\%). ${ }^{1} \mathrm{H}$ NMR (600 MHz; $\left.\mathrm{CDCl}_{3}\right): \delta 7.37-7.31(\mathrm{~m}, 5 \mathrm{H}), 5.67$ (ddt, $J=17.0,10.0,7.2$, $4 \mathrm{H}), 5.16(\mathrm{~s}, 2 \mathrm{H}), 5.04-5.01(\mathrm{~m}, 8 \mathrm{H}), 4.30-4.22(\mathrm{~m}, 4 \mathrm{H}), 4.17(\mathrm{dd}, J=11.0,8.7,4 \mathrm{H}), 4.11(\mathrm{dd}, J=11.1,6.3,4 \mathrm{H})$, $2.24(\mathrm{~d}, J=7.3,8 \mathrm{H}), 1.26(\mathrm{~s}, 3 \mathrm{H}), 1.16(\mathrm{~s}, 6 \mathrm{H}), 1.14(\mathrm{~s}, 24 \mathrm{H}) .{ }^{13} \mathrm{C} \mathrm{NMR}\left(176 \mathrm{MHz} ; \mathrm{CDCl}_{3}\right): \delta 176.8,172.1,135.5$ 134.0, 128.83, 128.66, 128.56, 118.3, 67.4, 66.2, 65.2, 46.85, 46.66, 44.7, 42.6, 24.9, 17.90, 17.75. MALDI: [M] $]_{\text {calc: }}$ : 897.5 $\mathrm{Da}[\mathrm{M}+\mathrm{Na}]^{+}$found: $920.3 \mathrm{Da}$.

\section{BnO-G3-(ene)8}

A $25 \mathrm{~mL}$ round-bottomed flask equipped with a magnetic stir bar was charged with 1,1 '-carbonyldiimidazole $(0.106$ g, $0.652 \mathrm{mmol}$ ) suspended in $0.33 \mathrm{~mL}$ of EtOAc and heated to $50{ }^{\circ} \mathrm{C}$. Compound 1 ( $\left.85 \mathrm{mg}, 0.665 \mathrm{mmol}\right)$ was added dropwise and stirred for 1 hour. BnO-G3-(OH) ${ }_{16}(0.050 \mathrm{~g}, 0.0543 \mathrm{mmol})$ and $\mathrm{CsF}(0.013 \mathrm{~g}, 0.087 \mathrm{mmol})$ was added 
in a single portion. The reaction progress was monitored by MALDI ( $\sim 6$ hours) and then quenched by the addition of $1 \mathrm{~mL}$ of water. The reaction mixture was then extracted with $3 \times 30 \mathrm{~mL}$ of $1 \mathrm{M} \mathrm{H}_{3} \mathrm{PO}_{4}, 3 \times 30 \mathrm{~mL}$ of $10 \%$

$\mathrm{Na}_{2} \mathrm{CO}_{3}, 1 \times 50 \mathrm{~mL}$ brine, dried over $\mathrm{MgSO}_{4}$, filtered, and solvent was removed by rotary evaporation to give the product as a clear, colourless oil. (60 mg, $51 \%) .{ }^{1} \mathrm{H}$ NMR $\left(700 \mathrm{MHz} ; \mathrm{CDCl}_{3}\right): \delta 7.37-7.30(\mathrm{~m}, 5 \mathrm{H}), 5.67(\mathrm{ddt}, J=$ 17.0, 10.1, 7.1, 8H), $5.15(\mathrm{~s}, 2 \mathrm{H}), 5.04-5.01(\mathrm{~m}, 16 \mathrm{H}), 4.31(\mathrm{~d}, J=11.0,2 \mathrm{H}), 4.23-4.13(\mathrm{~m}, 26 \mathrm{H}), 2.24(\mathrm{~d}, J=7.3$, $16 \mathrm{H}), 1.29(\mathrm{~s}, 3 \mathrm{H}), 1.23(\mathrm{~s}, 12 \mathrm{H}), 1.16(\mathrm{~s}, 6 \mathrm{H}), 1.14(\mathrm{~s}, 48 \mathrm{H}) .{ }^{13} \mathrm{C} \mathrm{NMR}\left(176 \mathrm{MHz} ; \mathrm{CDCl}_{3}\right): \delta 176.7,172.05,171.89$ $171.5,135.5,134.0,128.82,128.64,128.49,118.3,67.3,66.5,65.6,65.1,46.90,46.81,46.66,44.7,42.6,24.9$, 18.0, 17.65, 17.55. $[\mathrm{M}]_{\text {calc }}: 1802.2 \mathrm{Da}[\mathrm{M}+\mathrm{Na}]^{+}$found: $1824.8 \mathrm{Da}$.

\section{BnO-G4-(ene) 16}

A $25 \mathrm{~mL}$ round-bottomed flask equipped with a magnetic stir bar was charged with 1,1 '-carbonyldiimidazole $(0.110$ g, $0.681 \mathrm{mmol})$ dissolved in $0.3 \mathrm{~mL}$ of EtOAc and heated to $50^{\circ} \mathrm{C}$. Compound $\mathbf{1}(0.089 \mathrm{~g}, 0.694 \mathrm{mmol})$ was added dropwise and stirred for 1 hour. BnO-G4-(OH) $)_{16}(0.050 \mathrm{~g}, 0.027 \mathrm{mmol})$ was added, along with CsF $(0.013 \mathrm{~g}, 0.087$ mmol). The reaction mixture was stirred for 12 hours, until MALDI showed complete conversion and then quenched by the addition of $0.1 \mathrm{~mL}$ of water. The reaction mixture was then extracted with $3 \times 30 \mathrm{~mL}$ of $1 \mathrm{M} \mathrm{H}_{3} \mathrm{PO}_{4}, 3 \times 30$ $\mathrm{mL}$ of $10 \% \mathrm{Na}_{2} \mathrm{CO}_{3}, 1 \times 50 \mathrm{~mL}$ brine, dried over $\mathrm{MgSO}_{4}$, filtered, and solvent was removed by rotary evaporation to give the crude product as a clear, colourless oil. This was then purified by flash chromatography in a 12-gram silica gel column using a gradient of $5 \%$ to $30 \%$ acetone in hexanes over 20 column volumes, with UV monitoring at $205 \mathrm{~nm}$. The fractions containing product were pooled and solvent was removed by rotary evaporation, then dried in vacuo overnight to give the product as a clear, colourless oil. $(36 \mathrm{mg}, 37 \%) .{ }^{1} \mathrm{H} \mathrm{NMR}\left(600 \mathrm{MHz} ; \mathrm{CDCl}_{3}\right): \delta 7.35-$ $7.34(\mathrm{~m}, 4 \mathrm{H}), 7.33-7.31(\mathrm{~m}, 1 \mathrm{H}), 5.70-5.63(\mathrm{~m}, 16 \mathrm{H}), 5.15(\mathrm{~s}, 2 \mathrm{H}), 5.04(\mathrm{~d}, J=1.1,16 \mathrm{H}), 5.02-5.00(\mathrm{~m}, 16 \mathrm{H}), 4.33$ $(\mathrm{d}, J=10.9,2 \mathrm{H}), 4.26-4.13(\mathrm{~m}, 58 \mathrm{H}), 2.24(\mathrm{~d}, J=7.3,32 \mathrm{H}), 1.31(\mathrm{~s}, 3 \mathrm{H}), 1.23(\mathrm{~s}, 36 \mathrm{H}), 1.19(\mathrm{~s}, 6 \mathrm{H}), 1.14(\mathrm{~s}, 96 \mathrm{H})$. ${ }^{13} \mathrm{C}$ NMR (176 MHz; CDCl3): $\delta$ 176.7, 172.05, 171.86, 171.44, 171.36, 135.6, 134.0, 128.8, 128.6, 128.4, 118.3, $67.3,67.0,65.8,65.5,65.0,47.0,46.80,46.65,18.0,17.65,17.52,17.47 .[\mathrm{M}]_{\text {calc }}: 3609.9 \mathrm{Da}[\mathrm{M}+\mathrm{Na}]^{+}$found: 3635.2 Da.

\section{BnO-G5-(ene) ${ }_{32}$}


A $25 \mathrm{~mL}$ round-bottomed flask equipped with a magnetic stir bar was charged with compound $\mathbf{1}(0.177 \mathrm{~g}, 1.381$ mmol) dissolved in $0.5 \mathrm{~mL}$ of EtOAc at $50{ }^{\circ} \mathrm{C}$, then $1,1^{\prime}$-carbonyldiimidazole $(0.220 \mathrm{~g}, 1.359 \mathrm{mmol})$ was added and the reaction mixture vigorously bubbled off carbon dioxide. After 30 minutes, BnO-G5- $(\mathrm{OH})_{32}(0.050 \mathrm{~g}, 0.0135$ $\mathrm{mmol})$ and $\mathrm{CsF}(0.013 \mathrm{~g}, 0.086 \mathrm{mmol})$ was added in a single portion. The reaction mixture was stirred overnight, at which point MALDI showed complete conversion and the reaction was quenched by the addition of $1 \mathrm{~mL}$ of water. The reaction mixture was then extracted with $3 \times 30 \mathrm{~mL}$ of $1 \mathrm{M} \mathrm{H}_{3} \mathrm{PO}_{4}, 3 \times 30 \mathrm{~mL}$ of $10 \% \mathrm{Na}_{2} \mathrm{CO}_{3}, 1 \times 50$ $\mathrm{mL}$ brine, dried over $\mathrm{MgSO}_{4}$, filtered, and solvent was removed by rotary evaporation. The crude product was purified using a 10-gram silica gel column using a gradient from 5\% to $30 \%$ acetone:hexanes over 20 column volumes, with monitoring at $205 \mathrm{~nm}$. The fractions containing product were pooled and solvent was removed by rotary evaporation and dried in vacuo overnight to give the product as a clear, colourless oil. (61 mg, 62\%). ${ }^{1} \mathrm{H}$ NMR (600 MHz; CDCl3): $\delta$ 7.35-7.31 (m, 5H), 5.67 (dq, $J=17.2,8.6,32 \mathrm{H}), 5.15(\mathrm{~d}, J=0.4,2 \mathrm{H}), 5.03-5.00(\mathrm{~m}$, $64 \mathrm{H}), 4.36-4.13(\mathrm{~m}, 124 \mathrm{H}), 2.24(\mathrm{~d}, J=7.2,64 \mathrm{H}), 1.33(\mathrm{~s}, 3 \mathrm{H}), 1.25(\mathrm{~s}, 12 \mathrm{H}), 1.23(\mathrm{~s}, 72 \mathrm{H}), 1.18(\mathrm{~s}, 6 \mathrm{H}), 1.13(\mathrm{~s}$ 192H). ${ }^{13} \mathrm{C}$ NMR (176 MHz; CDCl3): $\delta$ 176.6, 172.0, 171.5, 134.0, 128.8, 128.4, 125.5, 121.9, 118.3, 65.3, 65.0, 46.79, 46.64, 44.7, 42.6, 24.9, 18.0, 17.69, 17.65, 17.4. [M] $]_{\text {calc: }} 7231.9 \mathrm{Da}\left[\mathrm{M}+\mathrm{CH}_{3} \mathrm{OH}\right]^{+}$found: $7264.4 \mathrm{Da}$.

\section{2,2-dimethylpent-4-ynoic Acid Periphery Dendrons (BnO-G $\left.\mathbf{x}_{\mathbf{x}}-\mathbf{y n e}\right)$}

\section{BnO-G1-(yne)}

A $25 \mathrm{~mL}$ round-bottomed flask equipped with a magnetic stir bar was charged with 1,1 '-carbonyldiimidazole $(0.108$ g, $0.669 \mathrm{mmol})$ suspended in $0.33 \mathrm{~mL}$ of EtOAc and heated to $50{ }^{\circ} \mathrm{C}$. Compound $2(86 \mathrm{mg}, 0.682 \mathrm{mmol})$ was added dropwise and stirred for 1 hour. BnO-G1-(OH) $2(0.050 \mathrm{~g}, 0.223 \mathrm{mmol})$ and $\mathrm{CsF}(0.014 \mathrm{~g}, 0.089 \mathrm{mmol})$ was added in a single portion. The reaction progress was monitored by MALDI ( $\sim 1$ hour) and then quenched by the addition of $1 \mathrm{~mL}$ of water. The reaction mixture was then extracted with $3 \times 30 \mathrm{~mL}$ of $1 \mathrm{M} \mathrm{H}_{3} \mathrm{PO}_{4}, 3 \times 30 \mathrm{~mL}$ of $10 \%$ $\mathrm{Na}_{2} \mathrm{CO}_{3}, 1 \times 50 \mathrm{~mL}$ brine, dried over $\mathrm{MgSO}_{4}$, filtered, and solvent was removed by rotary evaporation to give the crude product as a clear, colourless oil. This was then purified by flash chromatography in a 12-gram silica gel column using a gradient of $5 \%$ to $30 \%$ acetone in hexanes over 20 column volumes, with UV monitoring at 205 $\mathrm{nm}$. The fractions containing product were pooled and solvent was removed by rotary evaporation, then dried in vacuo overnight to give the product as a clear, colourless oil $(88 \mathrm{mg}, 90 \%) .{ }^{1} \mathrm{H} \mathrm{NMR}\left(600 \mathrm{MHz} ; \mathrm{CDCl}_{3}\right): \delta 7.37-$ 
$7.31(\mathrm{~m}, 5 \mathrm{H}), 5.16(\mathrm{~s}, 2 \mathrm{H}), 4.29-4.25(\mathrm{~m}, 4 \mathrm{H}), 2.35(\mathrm{~d}, J=2.6,4 \mathrm{H}), 1.29(\mathrm{~s}, 3 \mathrm{H}), 1.21(\mathrm{~d}, J=1.9,12 \mathrm{H}) .{ }^{13} \mathrm{C}$ NMR

(176 MHz; CDCl3): $\delta 175.9,172.6,135.6,128.8,128.6,128.4,80.9,70.8,67.1,65.8,46.7,42.4,29.6,24.6,18.0$.

$[\mathrm{M}]_{\text {calc: }}$ 440.2 Da $[\mathrm{M}+\mathrm{Na}]^{+}$found: $462.4 \mathrm{Da}$.

\section{BnO-G2-(yne) 4}

A $25 \mathrm{~mL}$ round-bottomed flask equipped with a magnetic stir bar was charged with 1,1 '-carbonyldiimidazole $(0.213$ g, $0.876 \mathrm{mmol})$ suspended in $0.66 \mathrm{~mL}$ of EtOAc and heated to $50{ }^{\circ} \mathrm{C}$. Compound $2(167 \mathrm{mg}, 0.889 \mathrm{mmol})$ was added dropwise and stirred for 1 hour. BnO-G2-(OH $)_{4}(0.050 \mathrm{~g}, 0.223 \mathrm{mmol})$ and $\mathrm{CsF}(0.013 \mathrm{~g}, 0.087 \mathrm{mmol})$ was added in a single portion. The reaction progress was monitored by MALDI ( $\sim 3$ hours) and then quenched by the addition of $1 \mathrm{~mL}$ of water. The reaction mixture was then extracted with $3 \times 30 \mathrm{~mL}$ of $1 \mathrm{M} \mathrm{H}_{3} \mathrm{PO}_{4}, 3 \times 30 \mathrm{~mL}$ of $10 \% \mathrm{Na} 2 \mathrm{CO} 3,1 \times 50 \mathrm{~mL}$ brine, dried over $\mathrm{MgSO}_{4}$, filtered, and solvent was removed by rotary evaporation to give the crude product as a clear, colourless oil. This was then purified by flash chromatography in a 12-gram silica gel column using a gradient of 5-30\% acetone in hexanes over 20 column volumes, with UV monitoring at $205 \mathrm{~nm}$. The fractions containing product were pooled and solvent was removed by rotary evaporation, then dried in vacuo overnight to give the product as a clear, colourless oil (38 mg, $40 \%) .{ }^{1} \mathrm{H} \mathrm{NMR}\left(600 \mathrm{MHz} ; \mathrm{CDCl}_{3}\right): \delta 7.38-7.32(\mathrm{~m}$, $5 \mathrm{H}), 5.17(\mathrm{~s}, 2 \mathrm{H}), 4.30(\mathrm{~d}, J=11.0,2 \mathrm{H}), 4.23(\mathrm{dt}, J=11.0,7.3,6 \mathrm{H}), 4.17(\mathrm{dd}, J=11.1,5.0,4 \mathrm{H}), 2.40(\mathrm{~d}, J=2.3$, 8H), $1.99(\mathrm{t}, J=2.5,4 \mathrm{H}), 1.27(\mathrm{~s}, 3 \mathrm{H}), 1.25(\mathrm{~s}, 23 \mathrm{H}), 1.19(\mathrm{~s}, 6 \mathrm{H}) .{ }^{13} \mathrm{C} \mathrm{NMR}\left(151 \mathrm{MHz}, \mathrm{CDCl}_{3}\right) \delta 175.84,172.07$, $128.86,128.71,128.60,80.92,70.92,67.38,66.15,65.32,46.84,46.72,42.44,29.65,24.67,17.86,17.77 .[\mathrm{M}]_{\text {calc: }}$ : 888.4 Da $[\mathrm{M}+\mathrm{Na}]^{+}$found: $912.1 \mathrm{Da}$.

\section{BnO-G3-(yne)8}

A $25 \mathrm{~mL}$ round-bottomed flask equipped with a magnetic stir bar was charged with 1,1 '-carbonyldiimidazole $(0.106$ g, $0.652 \mathrm{mmol})$ suspended in $0.33 \mathrm{~mL}$ of EtOAc and heated to $50{ }^{\circ} \mathrm{C}$. Compound $2(84 \mathrm{mg}, 0.652 \mathrm{mmol})$ was added dropwise and stirred for 1 hour. BnO-G3-(OH) 16 (0.050 g, $0.0543 \mathrm{mmol})$ and $\mathrm{CsF}(0.013 \mathrm{~g}, 0.087 \mathrm{mmol})$ was added in a single portion. The reaction progress was monitored by MALDI ( $\sim 6$ hours $)$ and then quenched by the addition of $1 \mathrm{~mL}$ of water. The reaction mixture was then extracted with $3 \times 30 \mathrm{~mL}$ of $1 \mathrm{M} \mathrm{H}_{3} \mathrm{PO}_{4}, 3 \times 30 \mathrm{~mL}$ of $10 \%$ $\mathrm{Na} 2 \mathrm{CO} 3,1 \times 50 \mathrm{~mL}$ brine, dried over $\mathrm{MgSO}_{4}$, filtered, and solvent was removed by rotary evaporation to give the crude product as a clear, colourless oil. This was purified by flash chromatography in a 12-gram silica gel column 
using a gradient of $5 \%$ to $30 \%$ acetone in hexanes over 20 column volumes, with UV monitoring at $205 \mathrm{~nm}$. The fractions containing product were pooled and solvent was removed by rotary evaporation, then dried in vacuo overnight to give the product as a clear, colourless oil (74 mg, 63\%). ${ }^{1} \mathrm{H}$ NMR $\left(700 \mathrm{MHz} ; \mathrm{CDCl}_{3}\right): \delta 7.40-7.34(\mathrm{~m}$, $5 \mathrm{H}), 5.19(\mathrm{~s}, 2 \mathrm{H}), 4.35-4.22(\mathrm{~m}, 28 \mathrm{H}), 2.42(\mathrm{~d}, J=2.5,16 \mathrm{H}), 2.03(\mathrm{t}, J=2.3,8 \mathrm{H}), 1.33(\mathrm{~s}, 3 \mathrm{H}), 1.28(\mathrm{~s}, 12 \mathrm{H}), 1.27$ $(\mathrm{s}, 48 \mathrm{H}), 1.20(\mathrm{~s}, 6 \mathrm{H}) .{ }^{13} \mathrm{C} \mathrm{NMR}\left(176 \mathrm{MHz} ; \mathrm{CDCl}_{3}\right): \delta 175.8,171.99,171.92,135.5,128.83,128.68,128.50,80.9$, $71.0,67.3,66.5,65.7,65.3,46.89,46.81,46.76,46.72,42.4,29.6,24.7,18.0,17.68,17.56,14.4$. [M] $]_{\text {calc: }}: 1785.9 \mathrm{Da}$ $[\mathrm{M}+\mathrm{Na}]^{+}$found: $1808.1 \mathrm{Da}$.

\section{BnO-G4-(yne) 16}

A $25 \mathrm{~mL}$ round-bottomed flask equipped with a magnetic stir bar was charged with 1,1 '-carbonyldiimidazole $(0.110$ $\mathrm{g}, 0.681 \mathrm{mmol})$ dissolved in $0.3 \mathrm{~mL}$ of EtOAc and heated to $50^{\circ} \mathrm{C}$. Compound $2(0.088 \mathrm{~g}, 0.694 \mathrm{mmol})$ was added dropwise and stirred for 1 hour. BnO-G4-(OH) $8(0.050 \mathrm{~g}, 0.027 \mathrm{mmol})$ and $\mathrm{CsF}(0.013 \mathrm{~g}, 0.087 \mathrm{mmol})$ was added in a single portion and stirred for 12 hours and monitored by MALDI and then quenched by the addition of $0.1 \mathrm{~mL}$ of water. The reaction mixture was then extracted with $3 \times 30 \mathrm{~mL}$ of $1 \mathrm{M} \mathrm{H}_{3} \mathrm{PO}_{4}, 3 \times 30 \mathrm{~mL}$ of $10 \% \mathrm{Na}_{2} \mathrm{CO}_{3}, 1 \times$ $50 \mathrm{~mL}$ brine, dried over $\mathrm{MgSO}_{4}$, filtered, and solvent was removed by rotary evaporation to give the crude product as a clear, colourless oil. This was then purified by flash chromatography in a 12-gram silica gel column using a gradient of $5 \%$ to $40 \%$ acetone in hexanes over 20 column volumes, with UV monitoring at $205 \mathrm{~nm}$. The fractions containing product were pooled and solvent was removed by rotary evaporation, then dried in vacuo overnight to give the product as a clear, colourless oil. (48 mg, 49\%). ${ }^{1} \mathrm{H}$ NMR (600 MHz; $\left.\mathrm{CDCl}_{3}\right): \delta 7.39(\mathrm{~d}, J=4.4,4 \mathrm{H}), 7.36$ $(\mathrm{dt}, J=8.6,3.8,1 \mathrm{H}), 5.19(\mathrm{~s}, 2 \mathrm{H}), 4.38-4.22(\mathrm{~m}, 60 \mathrm{H}), 2.43(\mathrm{~d}, J=2.6,32 \mathrm{H}), 2.04(\mathrm{t}, J=2.6,16 \mathrm{H}), 1.35(\mathrm{~s}, 3 \mathrm{H})$, $1.29(\mathrm{~s}, 24 \mathrm{H}), 1.28(\mathrm{~s}, 96 \mathrm{H}), 1.23(\mathrm{~s}, 6 \mathrm{H}) .{ }^{13} \mathrm{C} \mathrm{NMR}\left(176 \mathrm{MHz} ; \mathrm{CDCl}_{3}\right): \delta 175.8,172.0,171.50,171.43,135.6$ $128.85,128.65,128.4,81.0,71.0,67.3,66.9,65.8,65.5,65.2,46.82,46.72,42.4,29.6,18.0,17.67,17.56,17.51$. $[\mathrm{M}]_{\text {calc: }}$ 3579.7 Da $[\mathrm{M}+\mathrm{Na}]^{+}$found: $3601.8 \mathrm{Da}$.

\section{BnO-G5-(yne) 32}

A $25 \mathrm{~mL}$ round-bottomed flask equipped with a magnetic stir bar was charged with 1,1 '-carbonyldiimidazole $(0.138$ g, $0.850 \mathrm{mmol})$ dissolved in $0.3 \mathrm{~mL}$ of EtOAc and heated to $50^{\circ} \mathrm{C}$. Compound $2(0.107 \mathrm{~g}, 0.850 \mathrm{mmol})$ was added dropwise and stirred for 1 hour. BnO-G5-(OH) 8 (0.050 g, $0.014 \mathrm{mmol})$ and $\mathrm{CsF}(6.2 \mathrm{mg}, 0.041 \mathrm{mmol})$ was added 
in a single portion and stirred for 12 hours and monitored by MALDI and then quenched by the addition of $0.1 \mathrm{~mL}$ of water. The reaction mixture was then extracted with $3 \times 30 \mathrm{~mL}$ of $1 \mathrm{M} \mathrm{H}_{3} \mathrm{PO}_{4}, 3 \times 30 \mathrm{~mL}$ of $10 \% \mathrm{Na}_{2} \mathrm{CO}_{3}, 1 \times$ $50 \mathrm{~mL}$ brine, dried over $\mathrm{MgSO}_{4}$, filtered, and solvent was removed by rotary evaporation to give the crude product as a clear, colourless oil. This was then purified by flash chromatography in a 12-gram silica gel column using a gradient of $5 \%$ to $40 \%$ acetone in hexanes over 20 column volumes, with UV monitoring at $205 \mathrm{~nm}$. The fractions containing product were pooled and solvent was removed by rotary evaporation, then dried in vacuo overnight to give the product as a clear, colourless oil. (58 mg, 60\%). ${ }^{1} \mathrm{H}$ NMR (600 MHz, $\left.\mathrm{CDCl}_{3}\right) \delta 7.42-7.30(\mathrm{~m}, 5 \mathrm{H}), 5.17$ $(\mathrm{s}, 2 \mathrm{H}), 4.41-4.09(\mathrm{~m}, 124 \mathrm{H}), 2.40(\mathrm{~d}, J=2.7 \mathrm{~Hz}, 64 \mathrm{H}), 2.03(\mathrm{t}, J=2.7 \mathrm{~Hz}, 32 \mathrm{H}), 1.25-1.27(\mathrm{~m}, 285 \mathrm{H}) .{ }^{13} \mathrm{C}$ NMR $\left(151 \mathrm{MHz}, \mathrm{CDCl}_{3}\right) \delta 175.60,171.93,171.89,171.41,171.32,128.75,128.30,80.84,80.81,70.95,65.27,65.05$, $46.67,46.64,46.60,46.57,42.27,30.93,29.48,24.54,17.86,17.72,17.56,17.53,17.29$. [M] $]_{\text {calc: }} 7167.4 \mathrm{Da}$ $[\mathrm{M}+\mathrm{Na}]^{+}$found: $7192.5 \mathrm{Da}$.

\section{5-azido-2,2-dimethylpentanoic acid Periphery Dendrons $\left(\mathrm{BnO}-\mathrm{G}_{\mathbf{x}}-\mathrm{N}_{3}\right)$}

\section{BnO-G1- $\left(\mathbf{N}_{3}\right)_{2}$}

A $25 \mathrm{~mL}$ round-bottomed flask equipped with a magnetic stir bar was charged with 1,1 '-carbonyldiimidazole $(0.108$ g, $0.669 \mathrm{mmol})$ suspended in $0.33 \mathrm{~mL}$ of EtOAc and heated to $50{ }^{\circ} \mathrm{C}$. Compound $3(117 \mathrm{mg}, 0.682 \mathrm{mmol})$ was added dropwise and stirred for 1 hour. BnO-G3-(OH) $8(0.050 \mathrm{~g}, 0.2230 \mathrm{mmol})$ and $\mathrm{CsF}(0.014 \mathrm{~g}, 0.0892 \mathrm{mmol})$ was added in a single portion. The reaction mixture was stirred until TLC showed complete conversion ( $\sim 6$ hours) and then quenched by the addition of $0.1 \mathrm{~mL}$ of water. The reaction mixture was then extracted with $3 \times 30 \mathrm{~mL}$ of $10 \% \mathrm{Na}_{2} \mathrm{CO}_{3}, 3 \times 30 \mathrm{~mL}$ of $1 \mathrm{M} \mathrm{H}_{3} \mathrm{PO}_{4}, 1 \times 50 \mathrm{~mL}$ brine, dried over $\mathrm{MgSO}_{4}$, filtered, and solvent was removed by rotary evaporation to give the crude product as a clear, colourless oil. This was then purified by flash chromatography in a 12 -gram silica gel column using a gradient of 5\% to $30 \%$ acetone in hexanes over 20 column volumes, with UV monitoring at $205 \mathrm{~nm}$. The fractions containing product were pooled and solvent was removed by rotary evaporation, then dried in vacuo overnight to give the product as a clear, colourless oil (103 mg, 87\%), ${ }^{1} \mathrm{H}$ NMR (600 MHz; CDCl3): $\delta$ 7.37-7.33 (m, 5H), $5.16(\mathrm{~s}, 2 \mathrm{H}), 4.25-4.20(\mathrm{~m}, 4 \mathrm{H}), 3.22(\mathrm{t}, J=6.5,4 \mathrm{H}), 1.53$ (dq, $J=10.8,3.3,4 \mathrm{H}), 1.50-1.46(\mathrm{~m}, 4 \mathrm{H}), 1.29$ (s, 3H), $1.12(\mathrm{~s}, 12 \mathrm{H}) .{ }^{13} \mathrm{C} \mathrm{NMR}(176 \mathrm{MHz} ; \mathrm{CDCl}): \delta 176.9,172.6$ 
135.6, 128.8, 128.6, 128.3, 67.1, 65.6, 51.8, 46.7, 42.3, 37.6, 25.2, 24.7, 18.0. [M] $]_{\text {calc: }} 530.3 \mathrm{Da}[\mathrm{M}+\mathrm{Na}]^{+}{ }_{\text {found }}: 552.4$ Da.

\section{BnO-G2-( $\left.\mathbf{N}_{3}\right)_{4}$}

A $25 \mathrm{~mL}$ round-bottomed flask equipped with a magnetic stir bar was charged with 1,1 '-carbonyldiimidazole $(0.107$ g, $0.657 \mathrm{mmol})$ suspended in $0.33 \mathrm{~mL}$ of EtOAc and heated to $50{ }^{\circ} \mathrm{C}$. Compound $3(115 \mathrm{mg}, 0.670 \mathrm{mmol})$ was added dropwise and stirred for 1 hour. BnO-G2-(OH) $(0.050 \mathrm{~g}, 0.223 \mathrm{mmol})$ and $\mathrm{CsF}(0.014 \mathrm{~g}, 0.0892 \mathrm{mmol})$ was added in a single portion. The reaction mixture was stirred until TLC showed complete conversion ( $\sim 3$ hours) and then quenched by the addition of $0.1 \mathrm{~mL}$ of water. The reaction mixture was then extracted with $3 \times 30 \mathrm{~mL}$ of $10 \%$ $\mathrm{Na}_{2} \mathrm{CO}_{3}, 3 \times 30 \mathrm{~mL}$ of $1 \mathrm{M} \mathrm{H}_{3} \mathrm{PO}_{4}, 1 \times 50 \mathrm{~mL}$ brine, dried over $\mathrm{MgSO}_{4}$, filtered, and solvent was removed by rotary evaporation to give the crude product as a clear, colourless oil. This was then purified by flash chromatography in a 12-gram silica gel column using a gradient of $5 \%$ to $30 \%$ acetone in hexanes over 20 column volumes, with UV monitoring at $205 \mathrm{~nm}$. The fractions containing product were pooled and solvent was removed by rotary evaporation, then dried in vacuo overnight to give the product as a clear, colourless oil (71 mg, 61\%). ${ }^{1} \mathrm{H}$ NMR (600 $\left.\mathrm{MHz} ; \mathrm{CDCl}_{3}\right): \delta$ 7.41-7.36 (m, 5H), $5.19(\mathrm{~s}, 2 \mathrm{H}), 4.33-4.25(\mathrm{~m}, 4 \mathrm{H}), 4.21(\mathrm{dd}, J=11.0,8.7,4 \mathrm{H}), 4.13(\mathrm{dd}, J=11.0$, $6.8,4 \mathrm{H}), 3.28(\mathrm{t}, J=6.5,8 \mathrm{H}), 1.58(\mathrm{q}, J=3.8,9 \mathrm{H}), 1.55-1.50(\mathrm{~m}, 8 \mathrm{H}), 1.31(\mathrm{~s}, 3 \mathrm{H}), 1.20(\mathrm{~s}, 6 \mathrm{H}), 1.19(\mathrm{~s}, 24 \mathrm{H}) .{ }^{13} \mathrm{C}$ NMR (176 MHz; $\left.\mathrm{CDCl}_{3}\right): \delta 176.8,172.0,135.5,128.84,128.68,128.54,67.4,66.2,65.1,51.8,46.85,46.71,42.3$, 37.6, 25.2, 24.7, 17.81, 17.74. [M]calc: $1068.6 \mathrm{Da}[\mathrm{M}+\mathrm{Na}]^{+}$found: $1043.7 \mathrm{Da}$.

\section{BnO-G3-(N) $\mathbf{N}_{8}$}

A $25 \mathrm{~mL}$ round-bottomed flask equipped with a magnetic stir bar was charged with 1,1 ' -carbonyldiimidazole $(0.106$ g, $0.652 \mathrm{mmol})$ suspended in $0.33 \mathrm{~mL}$ of EtOAc and heated to $50{ }^{\circ} \mathrm{C}$. Compound $3(114 \mathrm{mg}, 0.664 \mathrm{mmol})$ was added dropwise and stirred for 1 hour. BnO-G3-(OH) $8(0.050 \mathrm{~g}, 0.0543 \mathrm{mmol})$ and $\mathrm{CsF}(0.013 \mathrm{~g}, 0.087 \mathrm{mmol})$ was added in a single portion. The reaction mixture was stirred until MALDI showed complete conversion ( $\sim 6$ hours $)$ and then quenched by the addition of $1 \mathrm{~mL}$ of water. The reaction mixture was then extracted with $3 \times 30 \mathrm{~mL}$ of 1 $\mathrm{M} \mathrm{H}_{3} \mathrm{PO}_{4}, 3 \times 30 \mathrm{~mL}$ of $10 \% \mathrm{Na}_{2} \mathrm{CO}_{3}, 1 \times 50 \mathrm{~mL}$ brine, dried over $\mathrm{MgSO}_{4}$, filtered, and solvent was removed by rotary evaporation to give the crude product as a clear, colourless oil. This was then purified by flash 
chromatography in a 12-gram silica gel column using a gradient of 5\% to $30 \%$ acetone in hexanes over 20 column volumes, with UV monitoring at $205 \mathrm{~nm}$. The fractions containing product were pooled and solvent was removed by rotary evaporation, then dried in vacuo overnight to give the product as a clear, colourless oil (74 mg, 63\%). ${ }^{1} \mathrm{H}$ NMR (700 MHz; $\left.\mathrm{CDCl}_{3}\right): \delta$ 7.38-7.32 (m, 5H), $5.16(\mathrm{~s}, 2 \mathrm{H}), 4.32(\mathrm{~d}, J=11.0,2 \mathrm{H}), 4.24-4.19(\mathrm{~m}, 18 \mathrm{H}), 4.14(\mathrm{dd}$, $J=11.1,4.3,8 \mathrm{H}), 3.25(\mathrm{t}, J=6.6,16 \mathrm{H}), 1.58-1.55(\mathrm{~m}, 16 \mathrm{H}), 1.53-1.48(\mathrm{~m}, 16 \mathrm{H}), 1.30(\mathrm{~s}, 3 \mathrm{H}), 1.24(\mathrm{~s}, 12 \mathrm{H}), 1.18$ (s, 6H), $1.16(\mathrm{~s}, 48 \mathrm{H}) .{ }^{13} \mathrm{C}$ NMR $\left(176 \mathrm{MHz} ; \mathrm{CDCl}_{3}\right): \delta 176.7,171.96,171.89,171.5,128.83,128.66,128.4,67.3$, $66.6,65.7,65.0,51.8,46.91,46.81,46.71,42.3,37.6,24.7,17.9,17.62,17.53 .[\mathrm{M}]_{\text {calc: }}: 2146.1 \mathrm{Da}[\mathrm{M}+\mathrm{Na}]^{+}$found: 2167.6 Da.

\section{BnO-G4-( $\left.\mathbf{N}_{3}\right)_{16}$}

A $25 \mathrm{~mL}$ round-bottomed flask equipped with a magnetic stir bar was charged with 1,1 '-carbonyldiimidazole $(0.110$ g, $0.681 \mathrm{mmol})$ dissolved in $0.3 \mathrm{~mL}$ of EtOAc and heated to $50^{\circ} \mathrm{C}$. Compound $2(0.088 \mathrm{~g}, 0.694 \mathrm{mmol})$ was added dropwise and stirred for 1 hour. BnO-G4-(OH) ${ }_{16}(0.050 \mathrm{~g}, 0.027 \mathrm{mmol})$ and $\mathrm{CsF}(0.013 \mathrm{~g}, 0.087 \mathrm{mmol})$ was added in a single portion. The reaction mixture was stirred for 12 hours, until MALDI showed complete conversion and then quenched with $0.1 \mathrm{~mL}$ of water. The reaction mixture was then extracted with $3 \times 30 \mathrm{~mL}$ of $1 \mathrm{M} \mathrm{H}_{3} \mathrm{PO}_{4}, 3 \times$ $30 \mathrm{~mL}$ of $10 \% \mathrm{Na} 2 \mathrm{CO} 3,1 \times 50 \mathrm{~mL}$ brine, dried over $\mathrm{MgSO}_{4}$, filtered, and solvent was removed by rotary evaporation to give the crude product as a clear, colourless oil. This was then purified by flash chromatography in a 12-gram silica gel column using a gradient of $5 \%$ to $40 \%$ acetone in hexanes over 20 column volumes, with UV monitoring at $205 \mathrm{~nm}$. The fractions containing product were pooled and solvent was removed by rotary evaporation, then dried in vacuo overnight to give the product as a clear, colourless oil. (93 mg, 80\%). ${ }^{1} \mathrm{H}$ NMR $\left(600 \mathrm{MHz} ; \mathrm{CDCl}_{3}\right): \delta 7.35(\mathrm{~d}, J=4.4,4 \mathrm{H}), 7.32(\mathrm{dt}, J=8.2,4.1,1 \mathrm{H}), 5.16(\mathrm{~s}, 2 \mathrm{H}), 4.34(\mathrm{~d}, J=10.9,2 \mathrm{H}), 4.27-$ $4.20(\mathrm{~m}, 42 \mathrm{H}), 4.13(\mathrm{dd}, J=11.0,5.6,16 \mathrm{H}), 3.25(\mathrm{t}, J=6.6,32 \mathrm{H}), 1.58-1.54(\mathrm{~m}, 32 \mathrm{H}), 1.52-1.47(\mathrm{~m}, 32 \mathrm{H}), 1.31$ $(\mathrm{s}, 3 \mathrm{H}), 1.24(\mathrm{~d}, J=3.3,36 \mathrm{H}), 1.19(\mathrm{~s}, 6 \mathrm{H}), 1.16(\mathrm{~s}, 96 \mathrm{H}) .{ }^{13} \mathrm{C} \mathrm{NMR}\left(176 \mathrm{MHz} ; \mathrm{CDCl}_{3}\right): \delta 176.7,171.97,171.87$ $171.43,171.37,135.6,128.8,128.6,128.4,67.3,67.0,65.8,65.4,65.0,51.8,46.79,46.68,42.3,37.5,25.2,24.7$, 17.9, 17.6, 17.4. $[\mathrm{M}]_{\text {calc: }}: 4300.2 \mathrm{Da}[\mathrm{M}+\mathrm{Na}]_{\text {found }}^{+}: 4273.9 \mathrm{Da}$. 


\section{BnO-G5-(N) $)_{32}$}

A $25 \mathrm{~mL}$ round-bottomed flask equipped with a magnetic stir bar was charged with 1,1 '-carbonyldiimidazole $(0.214$ g, $1.32 \mathrm{mmol})$ dissolved in $0.6 \mathrm{~mL}$ of EtOAc and heated to $50{ }^{\circ} \mathrm{C}$. Compound $2(0.222 \mathrm{~g}, 1.29 \mathrm{mmol})$ was added dropwise and stirred for 1 hour. BnO-G5-(OH) 32 (0.100 g, $0.027 \mathrm{mmol})$ and $\mathrm{CsF}(0.026 \mathrm{~g}, 0.173 \mathrm{mmol})$ was added in a single portion. The reaction mixture was stirred overnight at which point MALDI showed complete conversion and the reaction was quenched by the addition of $0.1 \mathrm{~mL}$ of water. The reaction mixture was then extracted with 3 $\times 30 \mathrm{~mL}$ of $1 \mathrm{M} \mathrm{H}_{3} \mathrm{PO}_{4}, 3 \times 30 \mathrm{~mL}$ of $10 \% \mathrm{Na}_{2} \mathrm{CO}_{3}, 1 \times 50 \mathrm{~mL}$ brine, dried over $\mathrm{MgSO}_{4}$, filtered, and solvent was removed by rotary evaporation to give the crude product as a clear, colourless oil. The crude was purified by flash chromatography in a 12-gram silica gel column using a gradient of 5\% to $40 \%$ acetone in hexanes over 20 column volumes, with UV monitoring at $205 \mathrm{~nm}$. The fractions containing product were pooled and solvent was removed by rotary evaporation, then dried in vacuo overnight to give the product as a clear, colourless oil. (165 mg, $71 \%$ ). ${ }^{1} \mathrm{H}$ NMR (600 MHz, $\left.\mathrm{CDCl}_{3}\right) \delta 7.41-7.29(\mathrm{~m}, 5 \mathrm{H}), 5.16(\mathrm{~s}, 2 \mathrm{H}), 4.42-3.96(\mathrm{~m}, 124 \mathrm{H}), 3.25(\mathrm{t}, J=6.7,64 \mathrm{H}), 1.64-$ $1.45(\mathrm{~m}, 137 \mathrm{H}), 1.25(\mathrm{~s}, 84 \mathrm{H}), 1.16(\mathrm{~s}, 192 \mathrm{H}) .{ }^{13} \mathrm{C} \mathrm{NMR}\left(151 \mathrm{MHz}, \mathrm{CDCl}_{3}\right) \delta 176.71,172.00,171.47,171.40$ $128.83,128.39,67.04,65.80,65.47,64.99,51.79,47.05,46.81,46.71,42.31,37.57,25.22,24.74,17.92,17.64$ 17.44. $[\mathrm{M}]_{\text {calc: }}: 8608.4 \mathrm{Da}[\mathrm{M}+\mathrm{H}]^{+}$found: $8500.3 \mathrm{Da}$.

\section{BnO-G5-Lin-( $\left.\mathbf{N}_{3}\right)_{32}$ Linear Azide}

A $25 \mathrm{~mL}$ round-bottomed flask equipped with a magnetic stir bar was charged with 1,1'-carbonyldiimidazole $(0.308$ g, $1.90 \mathrm{mmol})$ dissolved in $2 \mathrm{~mL}$ of EtOAc and heated to $50^{\circ} \mathrm{C}$. 5 -azidovaleric acid $(0.335 \mathrm{~g}, 1.96 \mathrm{mmol})$ was added dropwise and stirred for 1 hour. BnO-G5-(OH) $32(0.145 \mathrm{~g}, 0.039 \mathrm{mmol})$ was added, along with CsF $(0.038 \mathrm{~g}, 0.250$

mmol). The reaction mixture was stirred for overnight and monitored by MALDI and then quenched by the addition of $0.1 \mathrm{~mL}$ of water. The reaction mixture was extracted with $3 \times 30 \mathrm{~mL}$ of $1 \mathrm{M} \mathrm{H}_{3} \mathrm{PO}_{4}, 3 \times 30 \mathrm{~mL}$ of $10 \% \mathrm{Na}_{2} \mathrm{CO}_{3}$, $1 \times 50 \mathrm{~mL}$ brine, dried over $\mathrm{MgSO}_{4}$, filtered, and solvent was removed by rotary evaporation to give the crude product as a clear, colourless oil. This was then purified by flash chromatography in a 12-gram silica gel column using a gradient of $5 \%$ to $40 \%$ acetone in hexanes over 20 column volumes, with UV monitoring at $205 \mathrm{~nm}$. The fractions containing product were pooled and solvent was removed by rotary evaporation, then dried in vacuo 
overnight to give the product as a clear, colourless oil. $(128 \mathrm{mg}, 43 \%) .{ }^{1} \mathrm{H} \mathrm{NMR}\left(600 \mathrm{MHz}, \mathrm{CDCl}_{3}\right) \delta 7.36(\mathrm{~d}, J=$ $4.3 \mathrm{~Hz}, 4 \mathrm{H}), 7.33(\mathrm{~m}, 1 \mathrm{H}), 5.16(\mathrm{~s}, 1 \mathrm{H}), 4.43-3.94(\mathrm{~m}, 124 \mathrm{H}), 3.30(\mathrm{t}, J=6.7,64 \mathrm{H}), 2.36(\mathrm{t}, J=6.7,64 \mathrm{H}), 1.66$ $(\mathrm{m}, 135 \mathrm{H}), 1.32(\mathrm{~s}, 6 \mathrm{H}) 1.28-1.22(\mathrm{~m}, 80 \mathrm{H}) .{ }^{13} \mathrm{C} \mathrm{NMR}\left(151 \mathrm{MHz}, \mathrm{CDCl}_{3}\right) \delta$ 172.72, 172.16, 129.03, 128.32, 65.57, $65.12,51.14,48.83,46.78,46.52,33.57,33.47,28.39,28.37,22.19,22.12,17.93,17.73,17.44$.

\section{Preparation of Amine Periphery Dendrons}

\section{BnO-G5-(Neo- $\left.\mathrm{NH}_{3}{ }^{+} \mathrm{TFA}^{-}\right)_{32}$}

A $10 \mathrm{~mL}$ round-bottomed flask equipped with a magnetic stir bar was charged with BnO-G5-( $\left.\mathrm{N}_{3}\right)_{16}(13 \mathrm{mg}, 1.5$ $\mu \mathrm{mol})$ dissolved in $1 \mathrm{~mL}$ of 1:1 DCM:MeOH, along with $40 \mu \mathrm{l}$ of trifluoroacetic acid. $\mathrm{Pd}(\mathrm{OH})_{2} / \mathrm{C}(12 \mathrm{mg})$ was added, and the reaction mixture was purged and backfilled three times with hydrogen gas and was left to vigorously stir under a hydrogen atmosphere for overnight. The reaction mixture was then filtered through a $0.2 \mu \mathrm{m}$ PTFE filter, solvent was removed by rotary evaporation, and then dried in vacuo to give the product as a clear, colourless oil. (17 mg, 99\%) ${ }^{1} \mathrm{H}$ NMR (600 MHz, $\mathrm{D}_{2} \mathrm{O}$, vs. NaHCOO$\left.{ }^{-}\right) \delta 4.27$ (d, $\left.J=40.0 \mathrm{~Hz}, 148 \mathrm{H}\right), 2.99-2.94(\mathrm{~m}, 64 \mathrm{H})$, 1.59 (s, 135H), $1.30(\mathrm{~s}, 124 \mathrm{H}), 1.17(\mathrm{~s}, 230 \mathrm{H}) .{ }^{13} \mathrm{C}$ NMR (151 MHz, $\left.\mathrm{D}_{2} \mathrm{O}, \mathrm{vs} . \mathrm{NaHCOO}^{-}\right) \delta 179.19,163.89,163.66$ $163.42,163.19,119.86,117.93,115.99,114.06,66.00,47.25,42.63,40.16,36.77,24.96,23.18,17.83$. $[\mathrm{M}]_{\text {calc }}$ : 7776.7 Da (neutral amine) $[\mathrm{M}+\mathrm{H}]_{\text {found }}: 7702.5 \mathrm{Da}$.

\section{BnO-G5-(Lin- $\left.\mathrm{NH}_{3}{ }^{+} \mathrm{TFA}^{-}\right)_{32}$}

A $20 \mathrm{~mL}$ scintillation vial equipped with a magnetic stir bar was charged with BnO-G5-Lin-( $\left.\mathrm{N}_{3}\right)_{32}(22.5 \mathrm{mg}, 2.92$ $\mu \mathrm{mol})$ dissolved $1 \mathrm{~mL}$ of 1:1 DCM:MeOH, along with $40 \mu \mathrm{l}$ of trifluoroacetic acid. $\mathrm{Pd}(\mathrm{OH})_{2} / \mathrm{C}(10 \mathrm{mg})$ was added, and the reaction mixture was purged and backfilled three times with hydrogen gas and was left to vigorously stir under a hydrogen atmosphere for overnight. The reaction mixture was then filtered through a $0.22 \mu \mathrm{m}$ PTFE filter, solvent was removed by rotary evaporation, and then dried in vacuo to give the product as a clear, colourless oil. (14.9 mg, 96\%). ${ }^{1} \mathrm{H}$ NMR (600 MHz, $\left.\mathrm{D}_{2} \mathrm{O}\right) \delta 4.27(\mathrm{~d}, J=29.7 \mathrm{~Hz}, 164 \mathrm{H}), 3.00(\mathrm{t}, J=7.1 \mathrm{~Hz}, 64 \mathrm{H}), 2.45(\mathrm{t}, J=6.8$

$\mathrm{Hz}, 84 \mathrm{H}), 1.37-1.24(\mathrm{~m}, 100 \mathrm{H}) .{ }^{13} \mathrm{C} \mathrm{NMR}\left(151 \mathrm{MHz}, \mathrm{D}_{2} \mathrm{O}\right) \delta 174.78,163.16,162.92,162.69,162.45,119.24$, 
$117.31,115.37,113.43,65.85,65.35,63.85,57.73,48.29,46.58,46.40,39.03,32.96,32.90,26.18,21.12,17.02$, 16.65. $[\mathrm{M}]_{\text {calc }}: 10528.7 \mathrm{Da}[\mathrm{M}+\mathrm{H}]_{\text {found }}: 11185.3 \mathrm{Da},[\mathrm{M}+2 \mathrm{H}]^{2+}$ found $: 5626.5$

\section{Model Click Reactions}
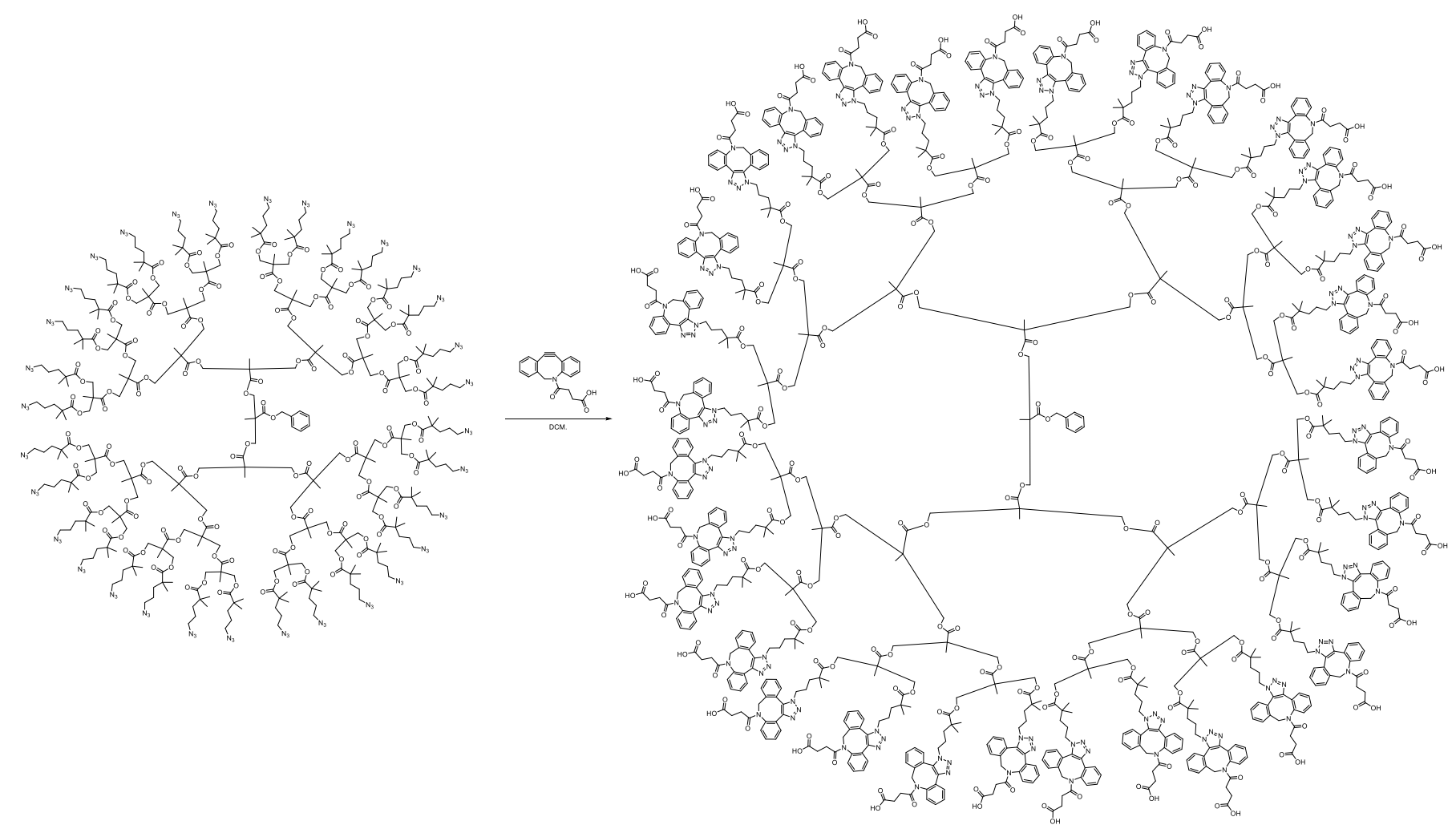

\section{BnO-G5-(N $)_{32}$ SPAAC with DBCO-COOH (BnO-G5-(DBCO) $\left.)_{32}\right)$}

In a $20 \mathrm{~mL}$ scintillation vial charged with a stir bar, BnO-G5-N $3(13 \mathrm{mg}, 1.51 \mu \mathrm{mol})$ was dissolved in $1 \mathrm{~mL}$ DCM, DBCO-COOH $(14.75 \mathrm{mg}, 48.32 \mu \mathrm{mol})$ was added in two portions between 2-minute intervals. The reaction was complete in 10 minutes by FTIR, and solvent was removed by rotary evaporator to yield BnO-G5-(DBCO) 32 as a white powder. $(27 \mathrm{mg}, 99 \%){ }^{1} \mathrm{H} \mathrm{NMR}\left(600 \mathrm{MHz}, \mathrm{CDCl}_{3}\right) \delta 7.74-7.33(\mathrm{~m}, 166 \mathrm{H}), 7.24-6.93(\mathrm{~m}, 116 \mathrm{H}), 4.30(\mathrm{~m}$, 223H), $2.51-0.96(\mathrm{~m}, 605 \mathrm{H}) .{ }^{13} \mathrm{C} \mathrm{NMR}\left(151 \mathrm{MHz}, \mathrm{CDCl}_{3}\right) \delta 177.08,175.59,172.15,171.84,170.72,144.98$, $142.61,141.31,140.18,135.84,134.61,133.70,132.62,131.79,131.49,130.87,129.89,129.74,129.58,128.99$, $128.49,127.95,127.55,127.35,124.48,65.04,53.04,51.68,49.69,48.89,46.78,42.26,42.20,37.22,36.52,29.86$, $29.58,29.22,28.55,25.60,25.02,24.82,17.91,17.67,17.37,1.16 .[\mathrm{M}]_{\text {calc: }}: 18374.0 \mathrm{Da}[\mathrm{M}+\mathrm{H}]_{\text {found: }}: 17534.8 \mathrm{Da}$, $[\mathrm{M}+2 \mathrm{H}]^{2+}$ found: 8889.1 

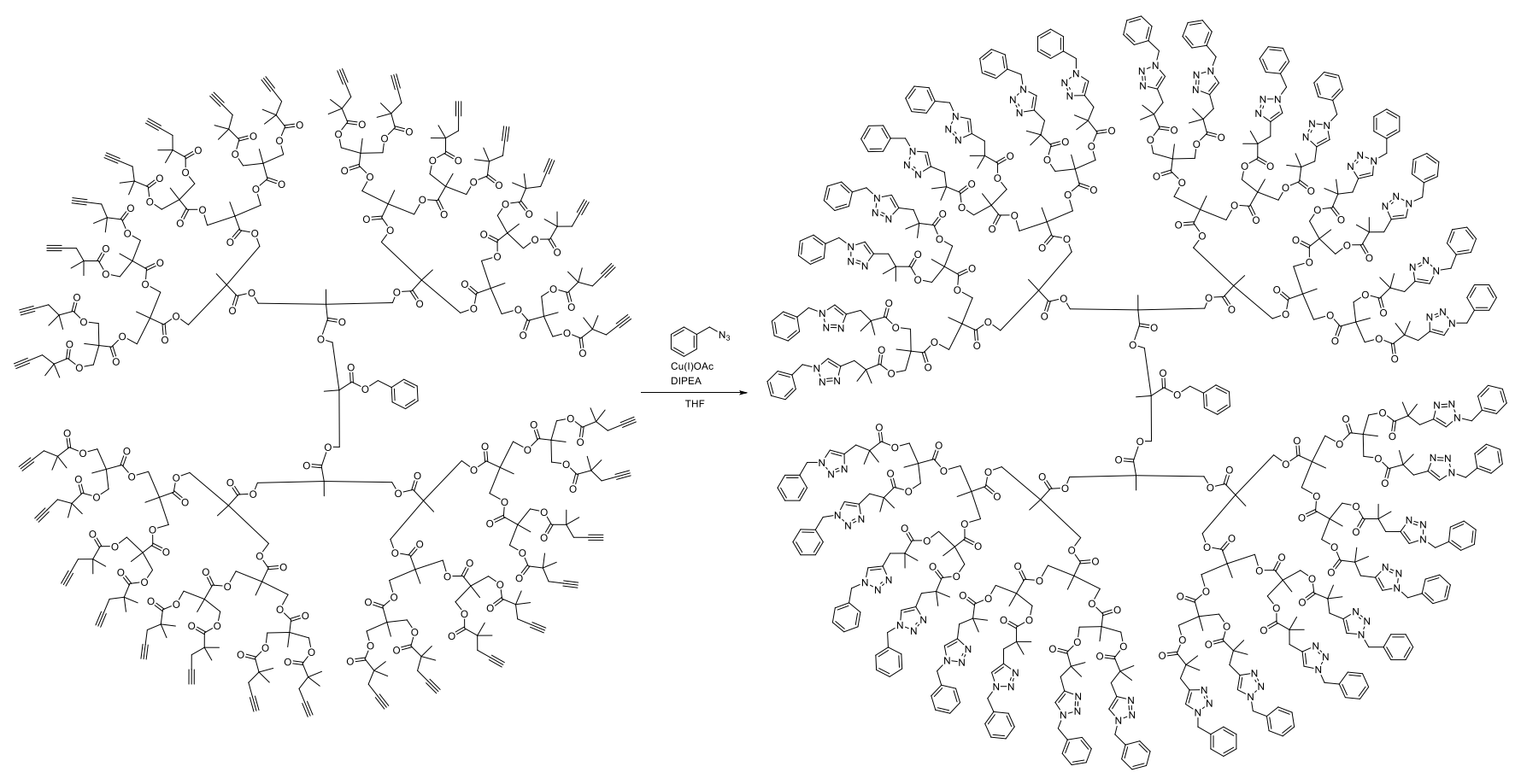

\section{BnO-G5-(yne) ${ }_{32}$ CuAAC with Benzyl Azide (BnO-G5-(BzTr) $)_{32}$ )}

In a $20 \mathrm{~mL}$ scintillation vial charged with a stir bar, BnO-G5-yne $3(10 \mathrm{mg}, 1.40 \mu \mathrm{mol})$ was dissolved in $0.5 \mathrm{~mL}$ dry THF. Benzyl azide $(7.3 \mu \mathrm{l}, 59 \mu \mathrm{mol})$ and DIPEA $(1.1 \mu \mathrm{l}, 5.8 \mu \mathrm{mol})$ was added to the stirring mixture, followed by a $0.5 \mathrm{~mL}$ solution of $\mathrm{Cu}(\mathrm{I}) \mathrm{OAc}(274 \mu \mathrm{g}, 2.23 \mu \mathrm{mol})$. The reaction was stirred vigorously at room temperature overnight. Solvent and excess benzyl azide was removed by rotary evaporator, and the crude was redissolved in 5 $\mathrm{mL}$ DCM and washed with 3 x $5 \mathrm{~mL}$ water. DCM was removed by rotary evaporator to yield BnO-G5-(BzTr) $)_{32}$ as a greenish sticky solid (14.8 mg, 93\%). ${ }^{1} \mathrm{H}$ NMR $\left(600 \mathrm{MHz}, \mathrm{CDCl}_{3}\right) \delta 7.43-7.27(\mathrm{~m}, 76 \mathrm{H}), 7.16(\mathrm{~d}, J=7.0 \mathrm{~Hz}$, 82H), $5.41(\mathrm{~s}, 64 \mathrm{H}), 4.16(\mathrm{~m}, 135 \mathrm{H}), 2.85(\mathrm{~s}, 64 \mathrm{H}), 1.35-1.15(\mathrm{~m}, 109 \mathrm{H}), 1.10(\mathrm{~s}, 285 \mathrm{H}) .{ }^{13} \mathrm{C} \mathrm{NMR}(151 \mathrm{MHz}$ $\left.\mathrm{CDCl}_{3}\right) \delta 176.52,172.10,171.57,144.38,135.34,129.11,128.61,127.98,122.81,65.07,53.89,46.69,42.95,35.86$ $32.07,30.25,29.85,25.01,22.84,17.81,17.67,14.27,1.16 .[\mathrm{M}]_{\text {calc: }}: 11426.4 \mathrm{Da}[\mathrm{M}+\mathrm{H}]_{\text {found }}: 11418.1 \mathrm{Da}$. 


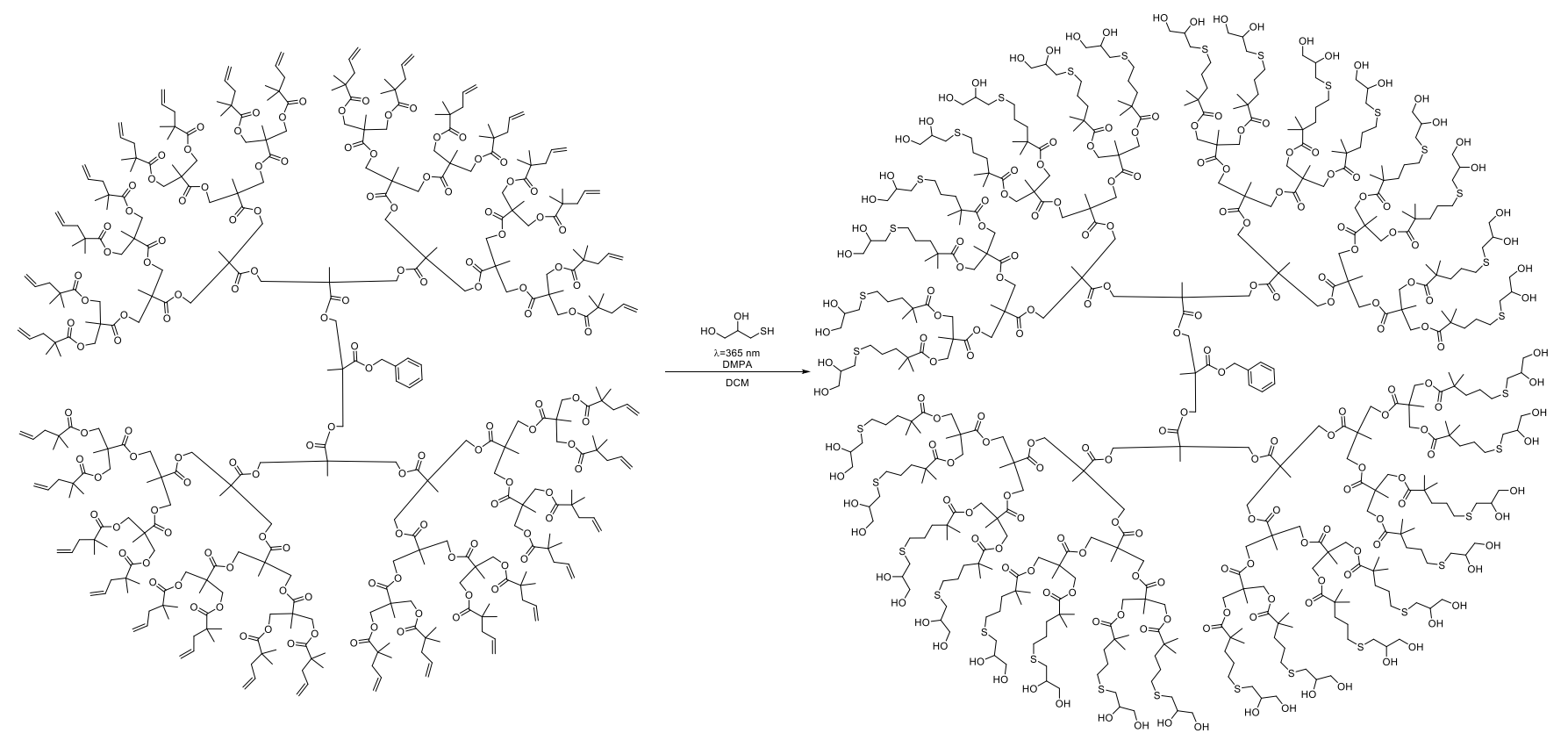

BnO-G5-(ene) 32 thiol-ene click with 1-thioglycerol (BnO-G5-(SR) ${ }_{32}$ )

In a $1 \mathrm{~mL}$ tube, BnO-G5-yne $3(10.6 \mathrm{mg}, 1.47 \mu \mathrm{mol}), 1$-thioglycerol $(6.1 \mu \mathrm{l}, 70.35 \mu \mathrm{mol})$ and DMPA $(263 \mu \mathrm{g}, 1.03$ $\mu \mathrm{mol}$ ) were dissolved in $0.1 \mathrm{~mL}$ acetonitrile. The mixture was irradiated with a handheld UV lamp at $365 \mathrm{~nm}$ for 30 minutes without stirring. The product partially precipitates out as an immiscible oil. Solvent and excess 1thioglycerol was removed by rotary evaporator to yield a colourless oil $(15.7 \mathrm{mg}, 99 \%)$. [M] $]_{\text {calc: }} 10689.7 \mathrm{Da}$ $[\mathrm{M}+\mathrm{H}]_{\text {found }}$ : $10429.9 \mathrm{Da} .{ }^{1} \mathrm{H}$ NMR $(600 \mathrm{MHz}, \mathrm{MeOD}) \delta 7.63-7.24(\mathrm{~m}, 5 \mathrm{H}), 5.25(\mathrm{~s}, 2 \mathrm{H}), 4.37-4.17(\mathrm{~m}, 128 \mathrm{H})$, $3.74(\mathrm{p}, J=5.8 \mathrm{~Hz}, 32 \mathrm{H}), 3.62(\mathrm{dd}, J=11.2,4.5 \mathrm{~Hz}, 32 \mathrm{H}), 3.54(\mathrm{dd}, J=11.2,5.9 \mathrm{~Hz}, 32 \mathrm{H}), 2.69(\mathrm{dd}, J=13.5,5.7$ $\mathrm{Hz}, 32 \mathrm{H}), 2.60-2.54(\mathrm{~m}, 90 \mathrm{H}), 1.67-1.61(\mathrm{~m}, 64 \mathrm{H}), 1.57-1.48(\mathrm{~m}, 64 \mathrm{H}), 1.33(\mathrm{~d}, J=7.4 \mathrm{~Hz}, 96 \mathrm{H}), 1.19(\mathrm{~s}$, 199H). ${ }^{13} \mathrm{C}$ NMR (151 MHz, MeOD) $\delta 178.35,173.55,173.09,72.87,66.31,66.09,43.58,43.52,40.87,36.47$, 34.13, 26.49, 25.94, 18.72, 18.55. [M $]_{\text {calc: }}$ 10689.7 Da [M+H $]_{\text {found: }} 10429.9 \mathrm{Da}$. 


\section{Hydrolytic Stability Studies}

\section{pH Degradation Studies}

Potassium phosphate buffers of $\mathrm{pH} 5.8,7.4$, and 8 were produced with $\mathrm{D}_{2} \mathrm{O}$ as the solvent, and then individually spiked with sodium formate and then diluted with $\mathrm{D}_{2} \mathrm{O}$ and $\mathrm{pH}$ adjusted with $\mathrm{HCl} / \mathrm{NaOH}$ to produce a $0.1 \mathrm{M}$ (as both buffer strength and standard) working solution. $500 \mu \mathrm{l}$ of the corresponding solution was added to 7-10 $\mathrm{mg}$ of the dendron of interest in a glass NMR tube and incubated at $37{ }^{\circ} \mathrm{C}$ and monitored periodically by ${ }^{1} \mathrm{H}$ NMR. All qNMR spectra were obtained on a Bruker Avance AV600 at $600 \mathrm{MHz}$ at room temperature. All hydrolysis NMR data were acquired with a $90^{\circ}$ pulse, 30 s relaxation delay (d1) and 20 spectral scans.

\section{Tracking NMR Data}

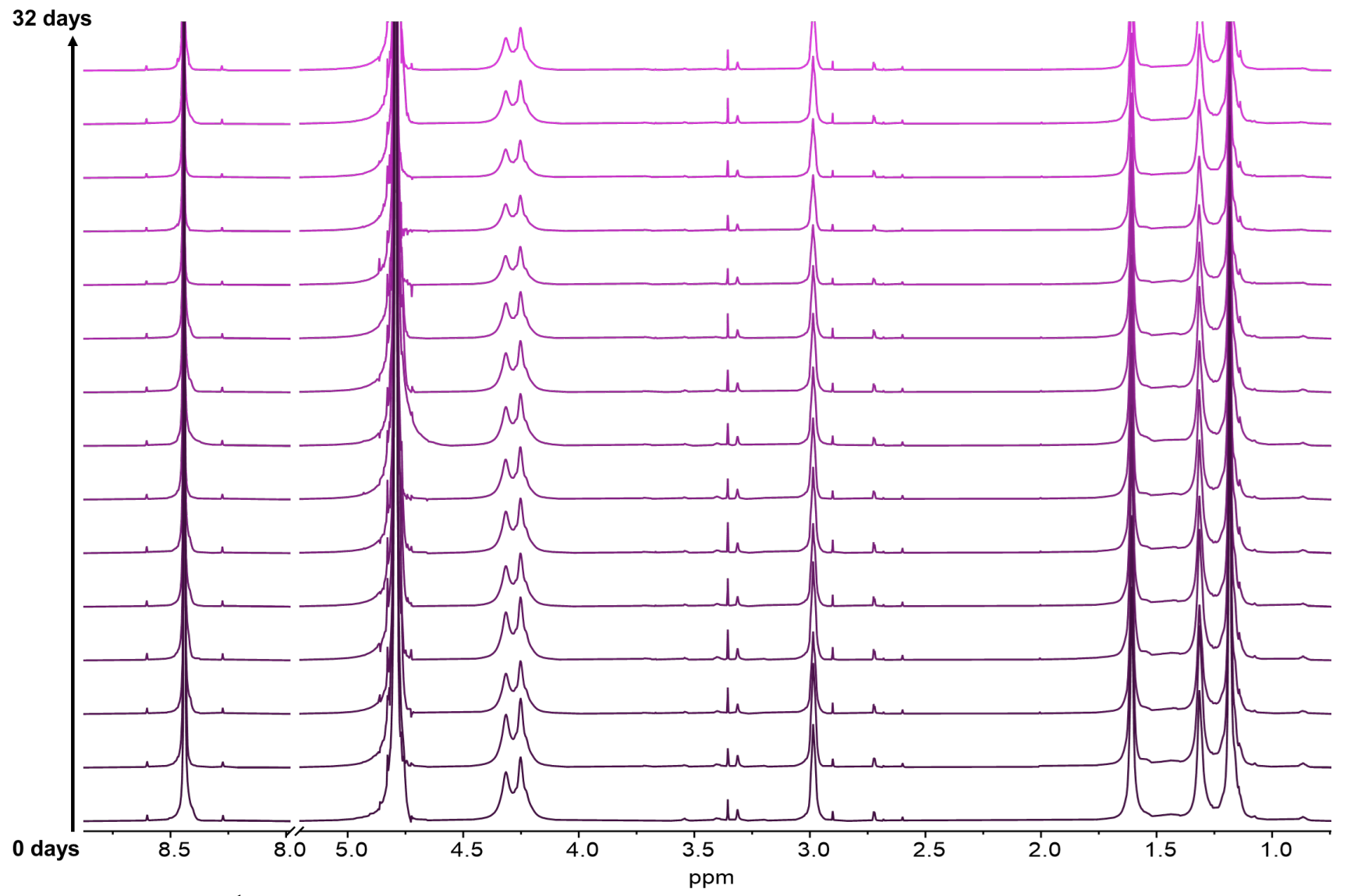

Figure S2. Tracking ${ }^{1} \mathrm{H}$ NMR of BnO-G5-(Neo- $\left.\mathbf{N H}_{3}{ }^{+} \mathbf{T F A}^{-}\right)_{32}$ in $0.1 \mathrm{M} \mathrm{pH} 5.8$ potassium phosphate buffer. 


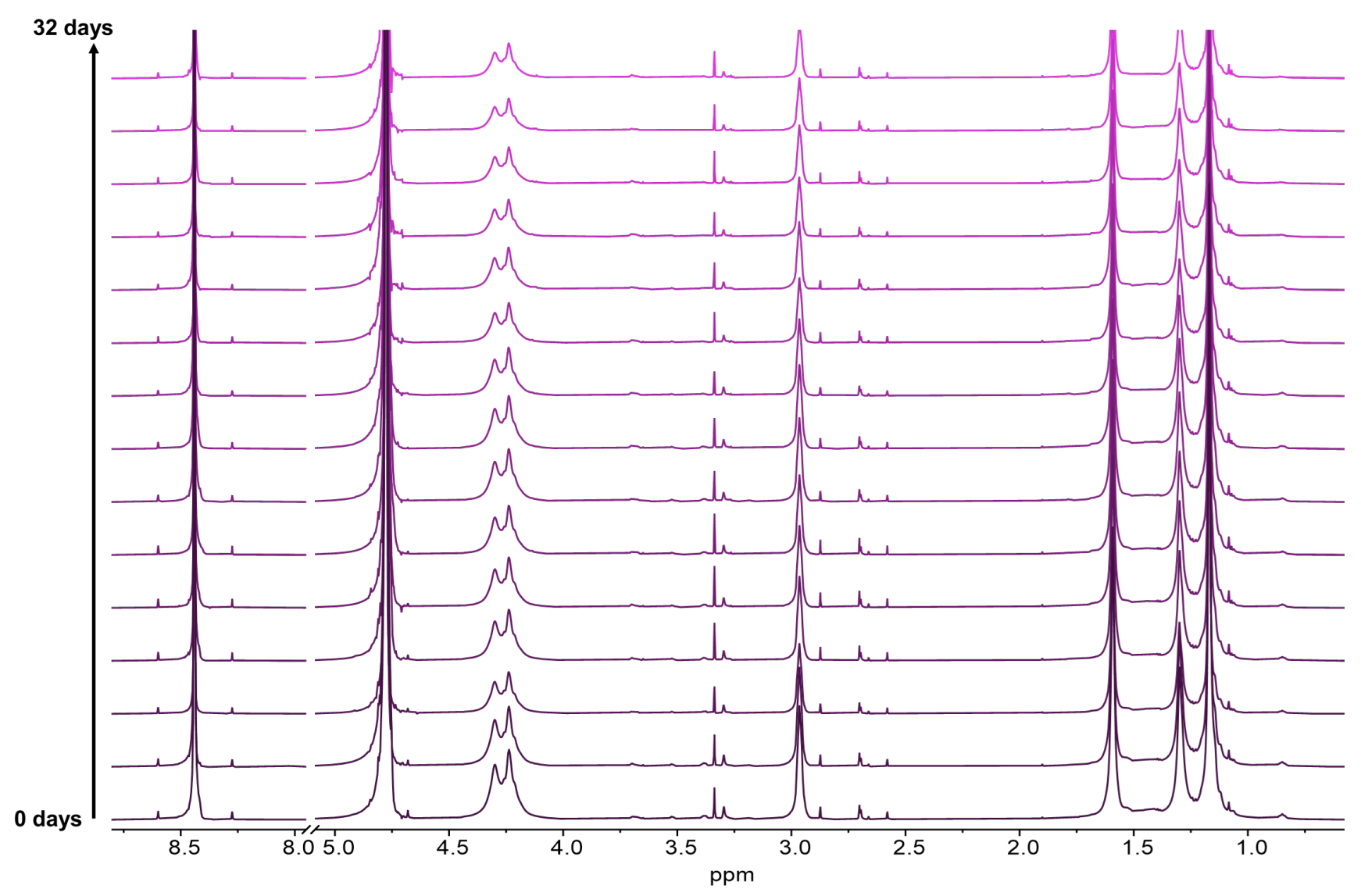

Figure S3. Tracking ${ }^{1} \mathrm{H}$ NMR of BnO-G5-(Neo- $\left.\mathbf{N H}_{3}{ }^{+} \mathbf{T F A}^{-}\right)_{32}$ in $0.1 \mathrm{M} \mathrm{pH} 7.4$ potassium phosphate buffer. 


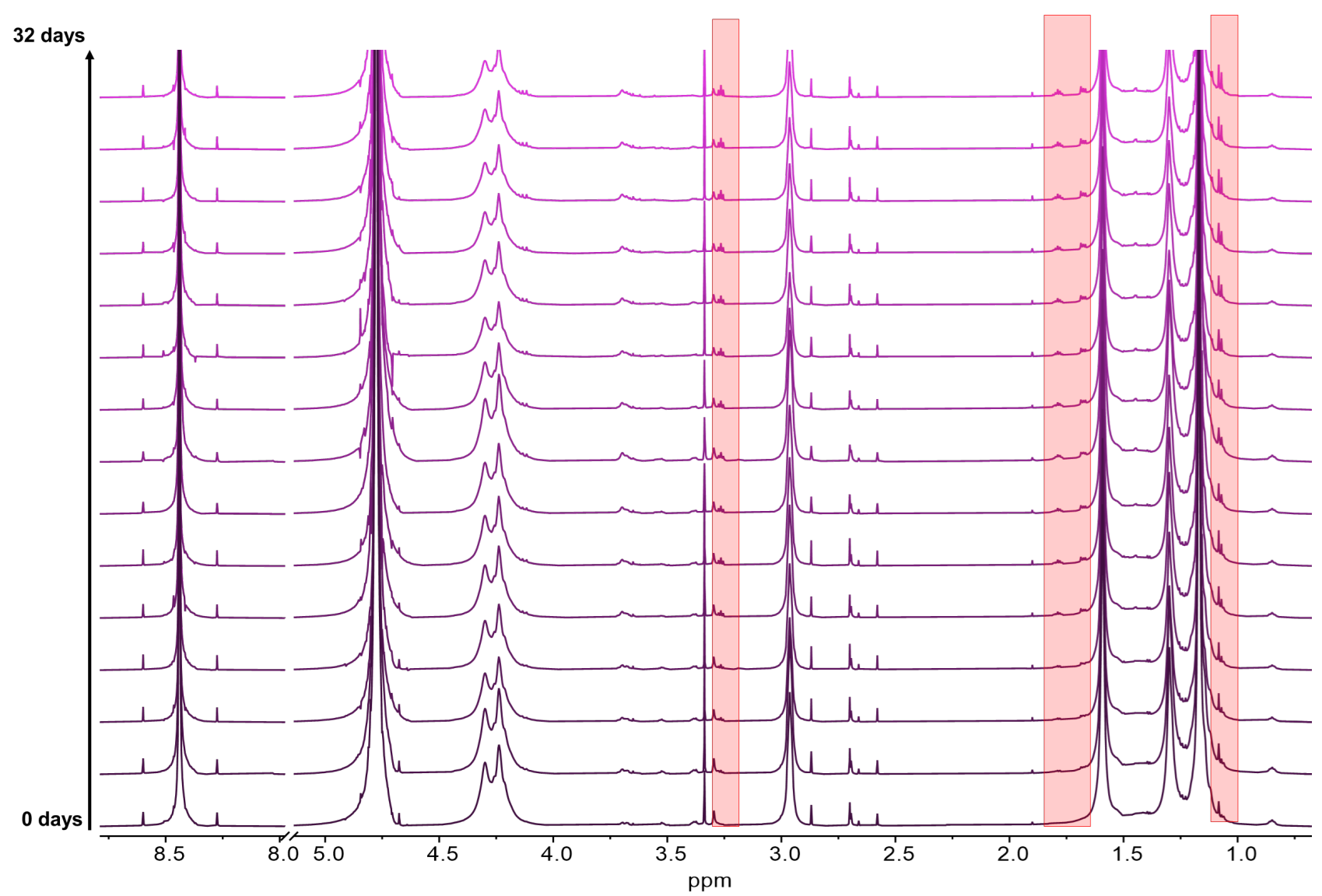

Figure S4. Tracking ${ }^{1} \mathrm{H}$ NMR of BnO-G5-(Neo- $\left.\mathbf{N H}_{3}{ }^{+} \mathbf{T F A}^{-}\right)_{32}$ in $0.1 \mathrm{M}$ pH 8 potassium phosphate buffer. Boxed signals are example degradation peaks from the amine and lactam. 


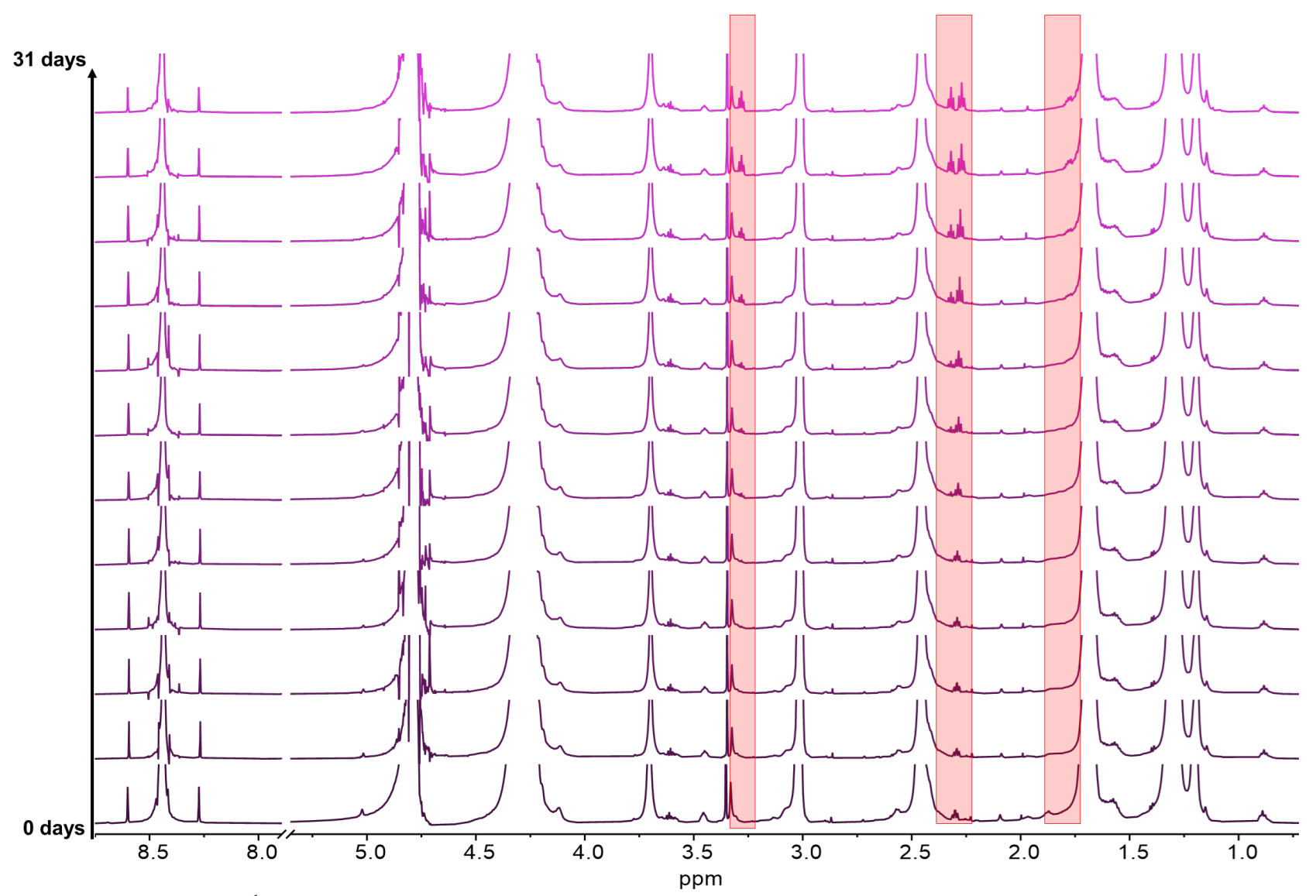

Figure S5. Tracking ${ }^{1} \mathrm{H}$ NMR of BnO-G5-(Lin- $\left.\mathbf{N H}_{3}{ }^{+} \mathbf{T F A}^{-}\right)_{32}$ in $0.1 \mathrm{M}$ pH 5.8 potassium phosphate buffer. Boxed signals are example degradation peaks from the amine and lactam. 


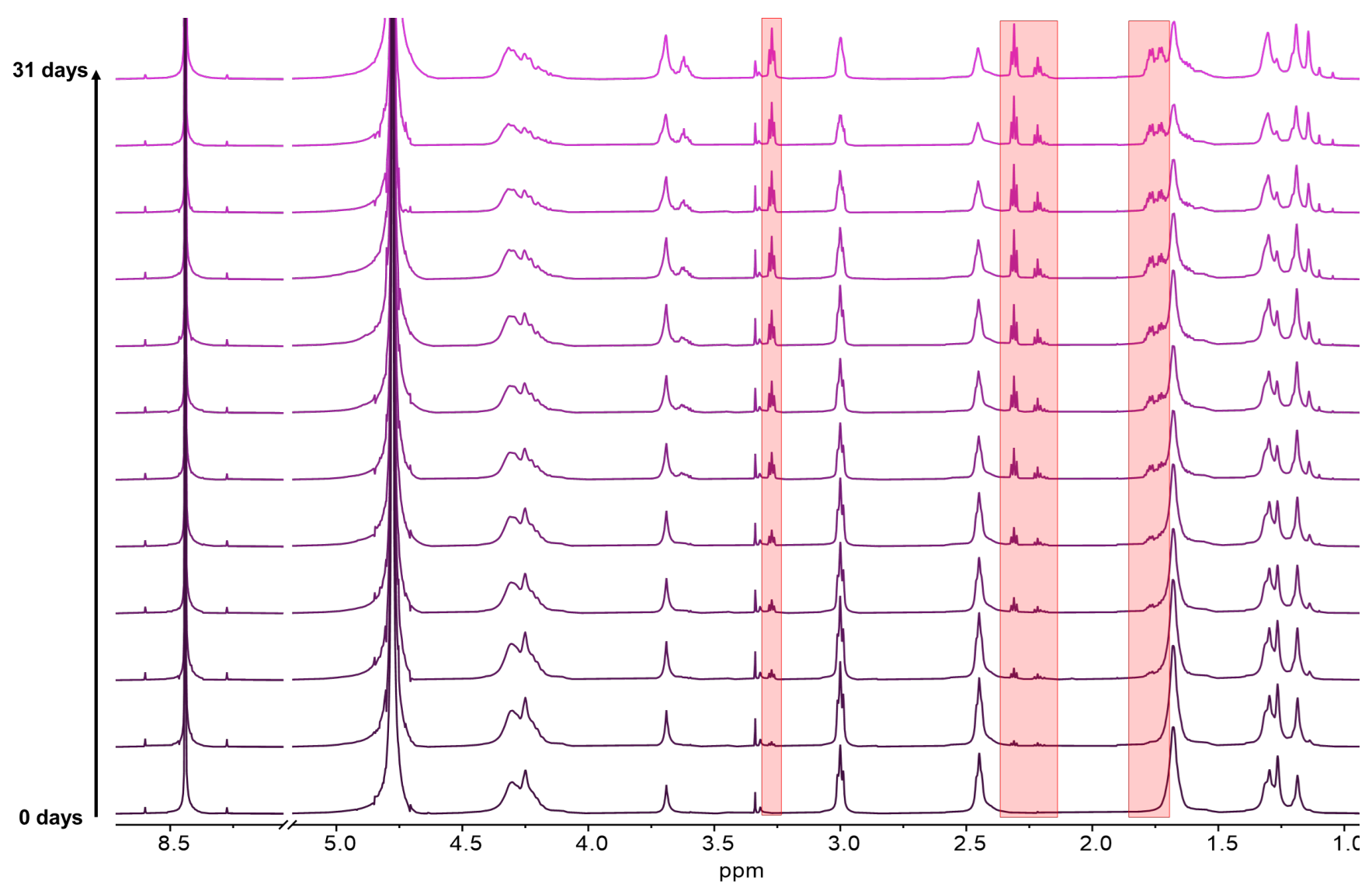

Figure S6. Tracking ${ }^{1} \mathrm{H}$ NMR of BnO-G5-(Lin- $\left.\mathbf{N H}_{3}{ }^{+} \mathbf{T F A}^{-}\right)_{32}$ in $0.1 \mathrm{M} \mathrm{pH} 7.4$ potassium phosphate buffer. Boxed signals are example degradation peaks from the amine and lactam. 


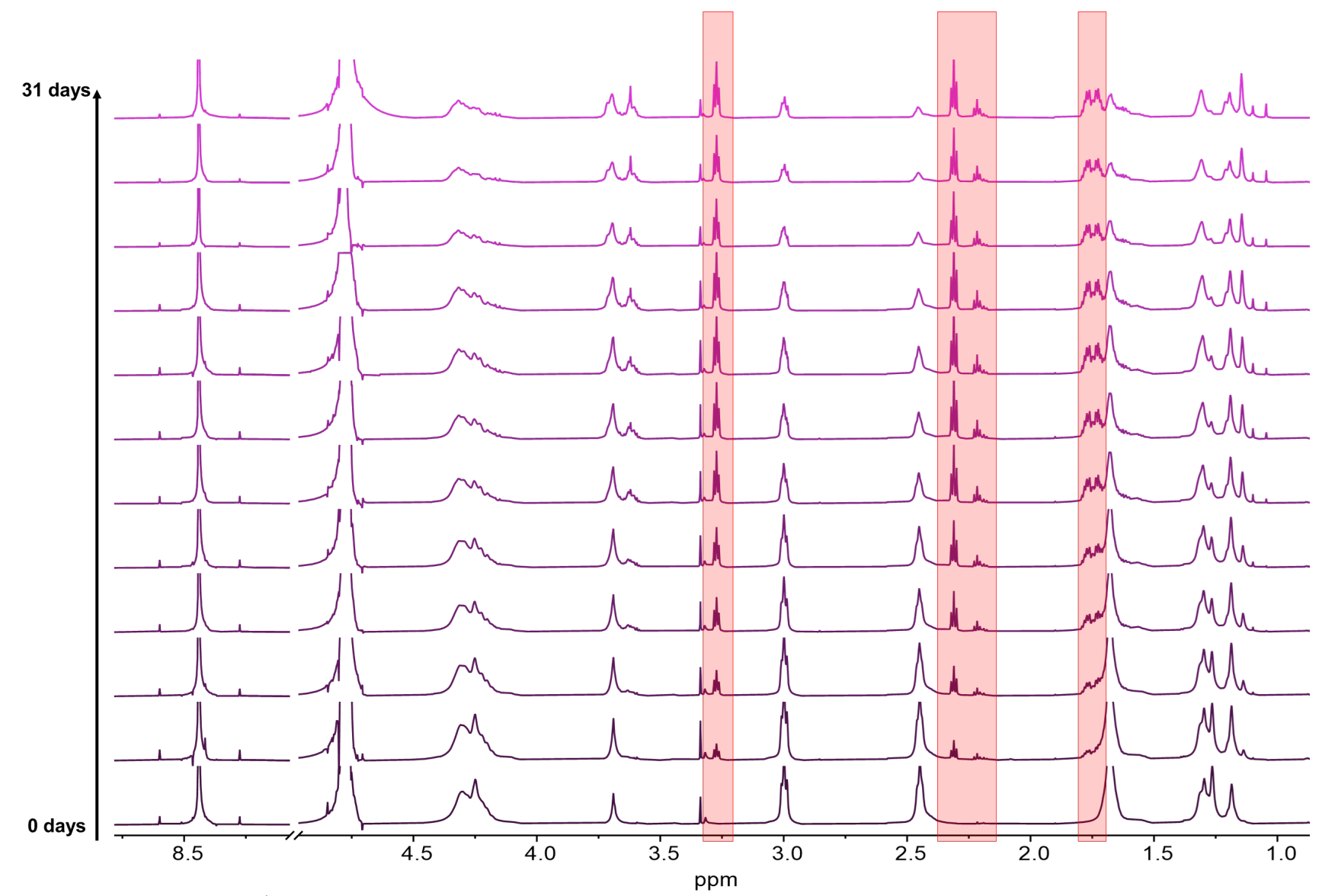

Figure S7. Tracking ${ }^{1} \mathrm{H}$ NMR of BnO-G5-(Lin- $\left.\mathbf{N H}_{3}{ }^{+} \mathbf{T F A}^{-}\right)_{32}$ in $0.1 \mathrm{M} \mathrm{pH} 8$ potassium phosphate buffer. Boxed signals are example degradation peaks from the amine and lactam.

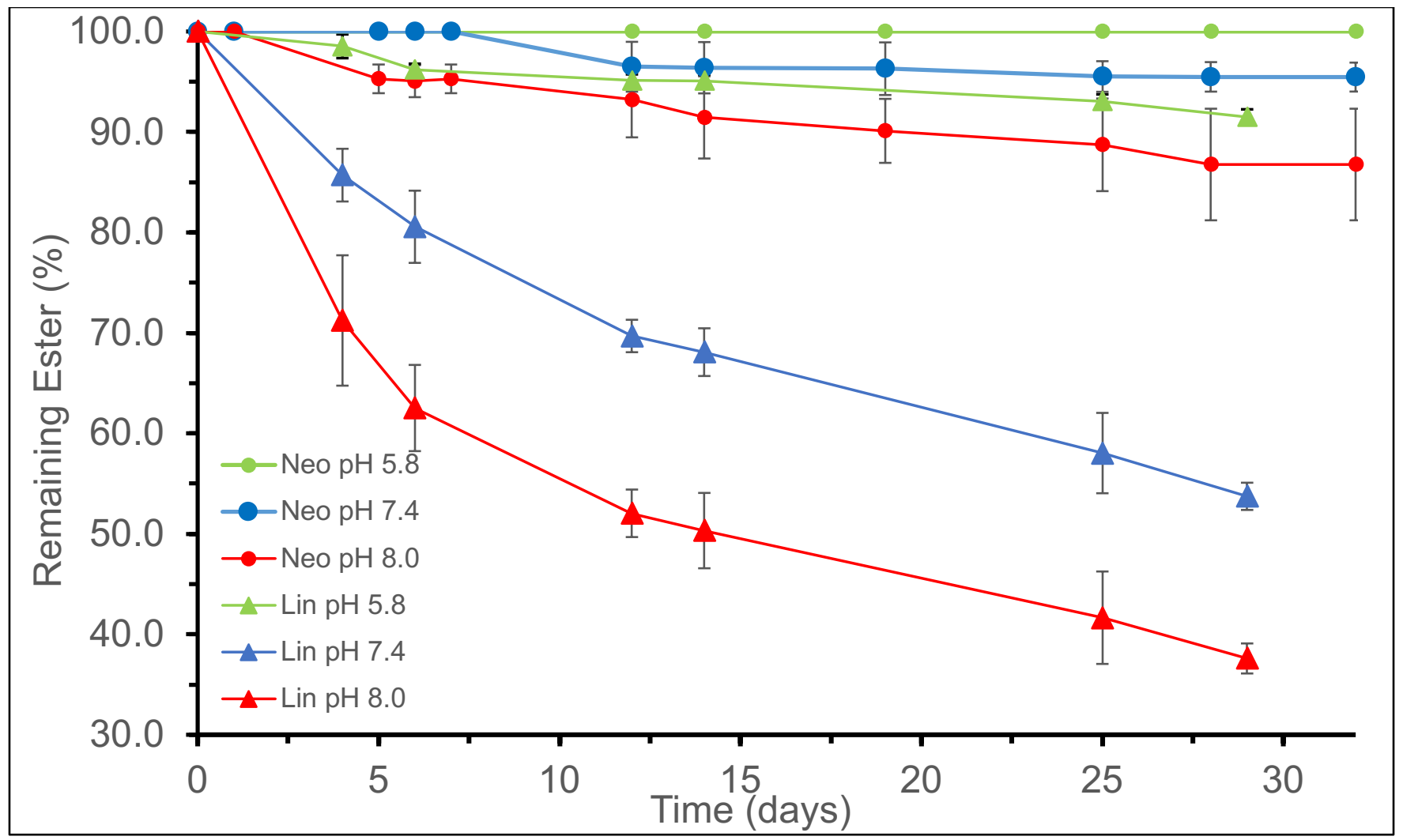


Figure S8. Compiled triplicate ${ }^{1} \mathrm{H}$ NMR measurements showing average $\%$ of intact dendrons over $\sim 1$ month.

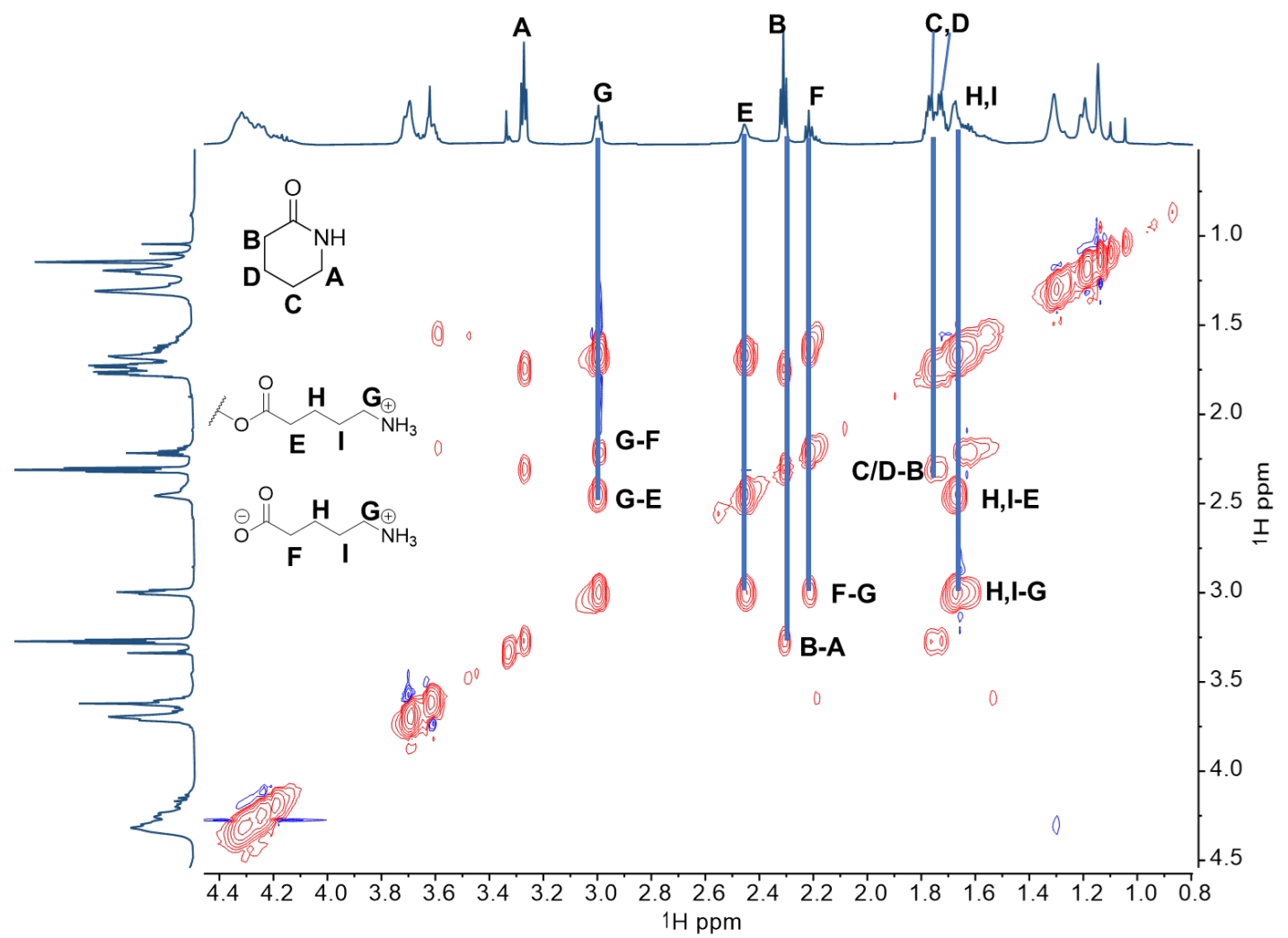

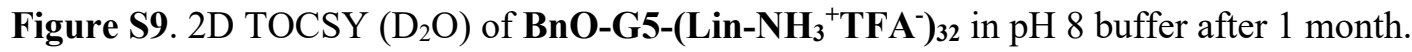


Table S1. Tracking ${ }^{1} \mathrm{H}$ NMR of BnO-G5-(Lin- $\left.\mathbf{N H}_{3}{ }^{+} \mathbf{T F A}^{-}\right)_{32}$ in $0.1 \mathrm{M} \mathrm{pH} 5.8$ potassium phosphate buffer, trial 1.

\begin{tabular}{|c|c|c|c|c|c|c|}
\hline \multicolumn{7}{|c|}{ Linear Periphery, pH 5.8} \\
\hline $\begin{array}{l}\text { Time } \\
\text { (days) }\end{array}$ & $\begin{array}{c}\text { Dendron- } \\
\text { bound amine } \\
\text { (t, } 2.45 \text { ppm), } \\
\text { (Int. vs. } \\
\text { HCOONa) }\end{array}$ & $\begin{array}{c}\text { Aminolysis; } \\
\text { ס- } \\
\text { valerolactam } \\
\text { (t, 2.31 ppm; } \\
\text { Int) }\end{array}$ & $\begin{array}{c}\text { Hydrolysis; } \\
5- \\
\text { aminovalerate } \\
\text { (t, } 2.2 \text { ppm; Int) }\end{array}$ & $\begin{array}{c}\text { 5-aminovalerate as a } \\
(\%) \text { of total amines }\end{array}$ & $\begin{array}{l}\text { Lactam as a (\%) } \\
\text { of total amines }\end{array}$ & $\begin{array}{c}\text { Intact } \\
\text { Amines (\%) }\end{array}$ \\
\hline 0 & 0.48 & 0 & 0.00 & 0.0 & 0.0 & 100.0 \\
\hline 4 & 0.48 & 0 & 0.00 & 0.0 & 0.0 & 100.0 \\
\hline 6 & 0.49 & 0.01 & 0.01 & 2.0 & 2.0 & 96.1 \\
\hline 12 & 0.49 & 0.01 & 0.02 & 3.8 & 1.9 & 94.2 \\
\hline 14 & 0.49 & 0.01 & 0.02 & 3.8 & 1.9 & 94.2 \\
\hline 25 & 0.49 & 0.02 & 0.02 & 3.8 & 3.8 & 92.5 \\
\hline 29 & 0.49 & 0.02 & 0.03 & 5.6 & 3.7 & 90.7 \\
\hline
\end{tabular}

Table S2. Tracking ${ }^{1} \mathrm{H}$ NMR of BnO-G5-(Lin-NH3$\left.{ }^{+} \mathbf{T F A}^{-}\right)_{32}$ in $0.1 \mathrm{M} \mathrm{pH} 5.8$ potassium phosphate buffer, trial 2.

\begin{tabular}{|c|c|c|c|c|c|c|}
\hline \multicolumn{7}{|c|}{ Linear Periphery, pH 5.8} \\
\hline $\begin{array}{l}\text { Time } \\
\text { (days) }\end{array}$ & $\begin{array}{c}\text { Dendron- } \\
\text { bound amine } \\
\text { (t, } 2.45 \text { ppm), } \\
\text { (Int. vs. } \\
\text { HCOONa) }\end{array}$ & $\begin{array}{c}\text { Aminolysis; } \\
\text { ס- } \\
\text { valerolactam } \\
\text { (t, 2.31 ppm; } \\
\text { Int) }\end{array}$ & $\begin{array}{c}\text { Hydrolysis; } \\
5- \\
\text { aminovalerate } \\
\text { (t, } 2.2 \text { ppm; Int) }\end{array}$ & $\begin{array}{l}\text { 5-aminovalerate as a } \\
(\%) \text { of total amines }\end{array}$ & $\begin{array}{l}\text { Lactam as a (\%) } \\
\text { of total amines }\end{array}$ & $\begin{array}{c}\text { Intact } \\
\text { Amines (\%) }\end{array}$ \\
\hline 0 & 0.62 & 0 & 0.00 & 0.0 & 0.0 & 100.0 \\
\hline 4 & 0.66 & 0 & 0.01 & 1.5 & 0.0 & 98.5 \\
\hline
\end{tabular}




\begin{tabular}{|r|r|r|r|r|r|r|}
\hline 6 & 0.64 & 0.01 & 0.01 & 1.5 & 1.5 & 97.0 \\
\hline 12 & 0.65 & 0.01 & 0.02 & 2.9 & 1.5 & 95.6 \\
\hline 14 & 0.64 & 0.01 & 0.02 & 3.0 & 1.5 & 95.5 \\
\hline 25 & 0.63 & 0.02 & 0.02 & 3.0 & 3.0 & 94.0 \\
\hline 29 & 0.62 & 0.03 & 0.03 & 4.4 & 4.4 & 91.2 \\
\hline
\end{tabular}

Table S3. Tracking ${ }^{1} \mathrm{H}$ NMR of BnO-G5-(Lin-NH$\left.{ }_{3}{ }^{+} \mathbf{T F A}^{-}\right)_{32}$ in $0.1 \mathrm{M} \mathrm{pH} 5.8$ potassium phosphate buffer, trial 3.

\begin{tabular}{|c|c|c|c|c|c|c|}
\hline \multicolumn{7}{|c|}{ Linear Periphery, pH 5.8} \\
\hline $\begin{array}{l}\text { Time } \\
\text { (days) }\end{array}$ & $\begin{array}{c}\text { Dendron- } \\
\text { bound amine } \\
\text { (t, } 2.45 \mathrm{ppm}) \\
\text { (Int. vs. } \\
\text { HCOONa) }\end{array}$ & $\begin{array}{c}\text { Aminolysis; } \\
\delta- \\
\text { valerolactam } \\
\text { (t, } 2.31 \text { ppm; } \\
\text { Int) }\end{array}$ & $\begin{array}{c}\text { Hydrolysis; } \\
5- \\
\text { aminovalerate } \\
\text { (t, } 2.2 \text { ppm; Int) }\end{array}$ & $\begin{array}{l}\text { 5-aminovalerate as a } \\
(\%) \text { of total amines }\end{array}$ & $\begin{array}{l}\text { Lactam as a (\%) } \\
\text { of total amines }\end{array}$ & $\begin{array}{c}\text { Intact } \\
\text { Amines (\%) }\end{array}$ \\
\hline 0 & 0.66 & 0 & 0.00 & 0.0 & 0.0 & 100.0 \\
\hline 4 & 0.67 & 0 & 0.02 & 2.9 & 0.0 & 97.1 \\
\hline 6 & 0.65 & 0.01 & 0.02 & 2.9 & 1.5 & 95.6 \\
\hline 12 & 0.64 & 0.01 & 0.02 & 3.0 & 1.5 & 95.5 \\
\hline 14 & 0.64 & 0.01 & 0.02 & 3.0 & 1.5 & 95.5 \\
\hline 25 & 0.63 & 0.02 & 0.03 & 4.4 & 2.9 & 92.6 \\
\hline 29 & 0.62 & 0.02 & 0.03 & 4.5 & 3.0 & 92.5 \\
\hline
\end{tabular}


Table S4. Tracking ${ }^{1} \mathrm{H}$ NMR of BnO-G5-(Neo- $\left.\mathbf{N H}_{3}{ }^{+} \mathbf{T F A}^{-}\right)_{32}$ in $0.1 \mathrm{M} \mathrm{pH} 5.8$ potassium phosphate buffer, trial 1.

\begin{tabular}{|c|c|c|c|c|c|c|}
\hline \multicolumn{7}{|c|}{ Neopentyl pH 5.8} \\
\hline $\begin{array}{l}\text { Time } \\
\text { (days) }\end{array}$ & $\begin{array}{c}\text { Dendron- } \\
\text { bound amine } \\
\text { (s, } 2.96 \text { ppm), } \\
\text { (Int. vs. } \\
\text { HCOONa) }\end{array}$ & $\begin{array}{c}\text { Aminolysis; } \\
\delta- \\
\text { valerolactam } \\
\text { (t, } 3.26 \mathrm{ppm} ; \\
\text { Int) }\end{array}$ & $\begin{array}{c}\text { Hydrolysis; } \\
5- \\
\text { aminovalerate } \\
\text { (s, 1.6 ppm; } \\
\text { Int) }\end{array}$ & $\begin{array}{l}\text { 5-aminovalerate as a } \\
\text { (\%) of total amines }\end{array}$ & $\begin{array}{l}\text { Lactam as a (\%) } \\
\text { of total amines }\end{array}$ & $\begin{array}{c}\text { Intact } \\
\text { Amines (\%) }\end{array}$ \\
\hline 0 & 0.34 & 0 & 0 & 0 & 0.0 & 100.0 \\
\hline 1 & 0.35 & 0 & 0 & 0 & 0.0 & 100.0 \\
\hline 5 & 0.35 & 0 & 0 & 0 & 0.0 & 100.0 \\
\hline 6 & 0.35 & 0 & 0 & 0 & 0.0 & 100.0 \\
\hline 7 & 0.35 & 0 & 0 & 0 & 0.0 & 100.0 \\
\hline 12 & 0.35 & 0 & 0 & 0 & 0.0 & 100.0 \\
\hline 14 & 0.36 & 0 & 0 & 0 & 0.0 & 100.0 \\
\hline 19 & 0.35 & 0 & 0 & 0 & 0.0 & 100.0 \\
\hline 25 & 0.35 & 0 & 0 & 0 & 0.0 & 100.0 \\
\hline 28 & 0.35 & 0 & 0 & 0 & 0.0 & 100.0 \\
\hline 32 & 0.35 & 0 & 0 & 0 & 0.0 & 100.0 \\
\hline
\end{tabular}

Table S5. Tracking ${ }^{1} \mathrm{H}$ NMR of BnO-G5-(Neo- $\left.\mathbf{N H}_{3}{ }^{+}{ }^{\mathbf{T F A}^{-}}\right)_{32}$ in $0.1 \mathrm{M} \mathrm{pH} 5.8$ potassium phosphate buffer, trial 2.

\begin{tabular}{|c|c|c|c|c|c|c|}
\hline \multicolumn{7}{|c|}{ Neopentyl pH 5.8} \\
\hline $\begin{array}{l}\text { Time } \\
\text { (days) }\end{array}$ & $\begin{array}{c}\text { Dendron- } \\
\text { bound amine } \\
\text { (s, } 2.96 \text { ppm), } \\
\text { (Int. vs. } \\
\text { HCOONa) }\end{array}$ & $\begin{array}{c}\text { Aminolysis; } \\
\delta- \\
\text { valerolactam } \\
\text { (t, } 3.26 \text { ppm; } \\
\text { Int) }\end{array}$ & $\begin{array}{c}\text { Hydrolysis; } \\
5- \\
\text { aminovalerate } \\
\text { (s, 1.6 ppm; } \\
\text { Int) }\end{array}$ & $\begin{array}{l}5 \text {-aminovalerate as a } \\
(\%) \text { of total amines }\end{array}$ & $\begin{array}{l}\text { Lactam as a (\%) } \\
\text { of total amines }\end{array}$ & $\begin{array}{c}\text { Intact } \\
\text { Amines (\%) }\end{array}$ \\
\hline 0 & 0.17 & 0 & 0 & 0 & 0.0 & 100.0 \\
\hline 1 & 0.18 & 0 & 0 & 0 & 0.0 & 100.0 \\
\hline 5 & 0.18 & 0 & 0 & 0 & 0.0 & 100.0 \\
\hline 6 & 0.17 & 0 & 0 & 0 & 0.0 & 100.0 \\
\hline
\end{tabular}




\begin{tabular}{|r|r|r|r|r|r|r|}
\hline 7 & 0.17 & 0 & 0 & 0.0 & 100.0 \\
\hline 12 & 0.17 & 0 & 0 & 0 & 0.0 & 100.0 \\
\hline 14 & 0.18 & 0 & 0 & 0 & 0.0 & 100.0 \\
\hline 19 & 0.17 & 0 & 0 & 0 & 0.0 & 100.0 \\
\hline 25 & 0.18 & 0 & 0 & 0 & 0.0 & 100.0 \\
\hline 28 & 0.17 & 0 & 0 & 0 & 0.0 & 100.0 \\
\hline 32 & 0.18 & 0 & 0 & 0 & 0.0 & 100.0 \\
\hline
\end{tabular}

Table S6. Tracking ${ }^{1} \mathrm{H}$ NMR of BnO-G5-(Neo- $\left.\mathbf{N H}_{3}{ }^{+}{ }^{\mathbf{T F A}}{ }^{-}\right)_{32}$ in $0.1 \mathrm{M} \mathrm{pH} 5.8$ potassium phosphate buffer, trial 3.

\begin{tabular}{|c|c|c|c|c|c|c|}
\hline \multicolumn{7}{|c|}{ Neopentyl pH 5.8} \\
\hline $\begin{array}{l}\text { Time } \\
\text { (days) }\end{array}$ & $\begin{array}{c}\text { Dendron- } \\
\text { bound amine } \\
\text { (s, } 2.96 \text { ppm), } \\
\text { (Int. vs. } \\
\text { HCOONa) }\end{array}$ & $\begin{array}{c}\text { Aminolysis; } \\
\delta- \\
\text { valerolactam } \\
\text { (t, } 3.26 \text { ppm; } \\
\text { Int) }\end{array}$ & $\begin{array}{c}\text { Hydrolysis; } \\
5- \\
\text { aminovalerate } \\
\text { (s, 1.6 ppm; } \\
\text { Int) }\end{array}$ & $\begin{array}{l}\text { 5-aminovalerate as a } \\
\text { (\%) of total amines }\end{array}$ & $\begin{array}{l}\text { Lactam as a (\%) } \\
\text { of total amines }\end{array}$ & $\begin{array}{c}\text { Intact } \\
\text { Amines (\%) }\end{array}$ \\
\hline 0 & 0.18 & 0 & 0 & 0 & 0.0 & 100.0 \\
\hline 1 & 0.19 & 0 & 0 & 0 & 0.0 & 100.0 \\
\hline 5 & 0.2 & 0 & 0 & 0 & 0.0 & 100.0 \\
\hline 6 & 0.19 & 0 & 0 & 0 & 0.0 & 100.0 \\
\hline 7 & 0.2 & 0 & 0 & 0 & 0.0 & 100.0 \\
\hline 12 & 0.2 & 0 & 0 & 0 & 0.0 & 100.0 \\
\hline 14 & 0.19 & 0 & 0 & 0 & 0.0 & 100.0 \\
\hline 19 & 0.19 & 0 & 0 & 0 & 0.0 & 100.0 \\
\hline 25 & 0.2 & 0 & 0 & 0 & 0.0 & 100.0 \\
\hline 28 & 0.2 & 0 & 0 & 0 & 0.0 & 100.0 \\
\hline 32 & 0.2 & 0 & 0 & 0 & 0.0 & 100.0 \\
\hline
\end{tabular}


Table S7. Tracking ${ }^{1} \mathrm{H}$ NMR of BnO-G5-(Lin- $\left.\mathbf{N H}_{3}{ }^{+} \mathbf{T F A}^{-}\right)_{32}$ in $0.1 \mathrm{M} \mathrm{pH} 7.4$ potassium phosphate buffer, trial 1

\begin{tabular}{|c|c|c|c|c|c|c|}
\hline \multicolumn{7}{|c|}{ Linear Periphery, pH 7.4} \\
\hline $\begin{array}{l}\text { Time } \\
\text { (days) }\end{array}$ & $\begin{array}{c}\text { Dendron- } \\
\text { bound amine } \\
\text { (t, } 2.45 \text { ppm), } \\
\text { (Int. vs. } \\
\text { HCOONa) }\end{array}$ & $\begin{array}{l}\text { Aminolysis; } \\
\text { ס- } \\
\text { valerolactam } \\
\text { (t, 2.31 ppm; } \\
\text { Int) }\end{array}$ & $\begin{array}{c}\text { Hydrolysis; } \\
5- \\
\text { aminovalerate } \\
\text { (t, } 2.2 \text { ppm; Int) }\end{array}$ & $\begin{array}{l}\text { 5-aminovalerate as a } \\
(\%) \text { of total amines }\end{array}$ & $\begin{array}{c}\text { Lactam as a (\%) } \\
\text { of total amines }\end{array}$ & $\begin{array}{c}\text { Intact } \\
\text { Amines (\%) }\end{array}$ \\
\hline 0 & 0.53 & 0 & 0.00 & 0.00 & 0.0 & 100 \\
\hline 4 & 0.5 & 0.03 & 0.03 & 5.36 & 5.4 & 89.3 \\
\hline 6 & 0.47 & 0.05 & 0.03 & 5.45 & 9.1 & 85.5 \\
\hline 12 & 0.41 & 0.1 & 0.06 & 10.53 & 17.5 & 71.9 \\
\hline 14 & 0.4 & 0.1 & 0.06 & 10.71 & 17.9 & 71.4 \\
\hline 25 & 0.35 & 0.13 & 0.07 & 12.73 & 23.6 & 63.6 \\
\hline 29 & 0.3 & 0.16 & 0.08 & 14.81 & 29.6 & 55.6 \\
\hline
\end{tabular}

Table S8. Tracking ${ }^{1} \mathrm{H}$ NMR of BnO-G5-(Lin- $\left.\mathbf{N H}_{3}{ }^{+} \mathbf{T F A}^{-}\right)_{32}$ in $0.1 \mathrm{M} \mathrm{pH} 7.4$ potassium phosphate buffer, trial 2

\begin{tabular}{|c|c|c|c|c|c|c|}
\hline \multicolumn{7}{|c|}{ Linear Periphery, pH 7.4} \\
\hline $\begin{array}{l}\text { Time } \\
\text { (days) }\end{array}$ & $\begin{array}{c}\text { Dendron- } \\
\text { bound amine } \\
\text { (t, } 2.45 \text { ppm), } \\
\text { (Int. vs. } \\
\text { HCOONa) }\end{array}$ & $\begin{array}{c}\text { Aminolysis; } \\
\text { ס- } \\
\text { valerolactam } \\
\text { (t, 2.31 ppm; } \\
\text { Int) }\end{array}$ & $\begin{array}{c}\text { Hydrolysis; } \\
5- \\
\text { aminovalerate } \\
\text { (t, } 2.2 \text { ppm; Int) }\end{array}$ & $\begin{array}{l}\text { 5-aminovalerate as a } \\
(\%) \text { of total amines }\end{array}$ & $\begin{array}{l}\text { Lactam as a (\%) } \\
\text { of total amines }\end{array}$ & $\begin{array}{c}\text { Intact } \\
\text { Amines (\%) }\end{array}$ \\
\hline 0 & 0.63 & 0 & 0.00 & 0.00 & 0.0 & 100 \\
\hline 4 & 0.54 & 0.08 & 0.03 & 4.62 & 12.3 & 83.1 \\
\hline 6 & 0.5 & 0.11 & 0.04 & 6.15 & 16.9 & 76.9 \\
\hline
\end{tabular}




\begin{tabular}{|r|r|r|r|r|r|r|} 
& 0.15 & 0.06 & 9.09 & 68.2 \\
\hline 12 & 0.43 & 0.16 & 0.06 & 9.23 & 22.7 \\
\hline 25 & 0.36 & 0.21 & 0.09 & 13.64 & 24.6 & 31.8 \\
\hline 29 & 0.34 & 0.22 & 0.09 & 13.85 & 54.5 \\
\hline
\end{tabular}

Table S9. Tracking ${ }^{1} \mathrm{H}$ NMR of BnO-G5-(Lin- $\left.\mathbf{N H}_{3}{ }^{+} \mathbf{T F A}^{-}\right)_{32}$ in $0.1 \mathrm{M} \mathrm{pH} 7.4$ potassium phosphate buffer, trial 3

\begin{tabular}{|c|c|c|c|c|c|c|}
\hline \multicolumn{7}{|c|}{ Linear Periphery, pH 7.4} \\
\hline $\begin{array}{l}\text { Time } \\
\text { (days) }\end{array}$ & $\begin{array}{c}\text { Dendron- } \\
\text { bound amine } \\
\text { (t, } 2.45 \text { ppm), } \\
\text { (Int. vs. } \\
\text { HCOONa) }\end{array}$ & $\begin{array}{c}\text { Aminolysis; } \\
\text { ס- } \\
\text { valerolactam } \\
\text { (t, 2.31 ppm; } \\
\text { Int) }\end{array}$ & $\begin{array}{c}\text { Hydrolysis; } \\
5- \\
\text { aminovalerate } \\
\text { (t, } 2.2 \text { ppm; Int) }\end{array}$ & $\begin{array}{l}\text { 5-aminovalerate as a } \\
(\%) \text { of total amines }\end{array}$ & $\begin{array}{l}\text { Lactam as a (\%) } \\
\text { of total amines }\end{array}$ & $\begin{array}{c}\text { Intact } \\
\text { Amines (\%) }\end{array}$ \\
\hline 0 & 0.61 & 0 & 0.00 & 0.00 & 0.0 & 100 \\
\hline 4 & 0.5 & 0.07 & 0.02 & 3.39 & 11.9 & 84.7 \\
\hline 6 & 0.46 & 0.09 & 0.03 & 5.17 & 15.5 & 79.3 \\
\hline 12 & 0.4 & 0.13 & 0.05 & 8.62 & 22.4 & 69.0 \\
\hline 14 & 0.4 & 0.14 & 0.06 & 10.00 & 23.3 & 66.7 \\
\hline 25 & 0.33 & 0.18 & 0.08 & 13.56 & 30.5 & 55.9 \\
\hline 29 & 0.32 & 0.19 & 0.09 & 15.00 & 31.7 & 53.3 \\
\hline
\end{tabular}


Table S10. Tracking ${ }^{1} \mathrm{H}$ NMR of BnO-G5-(Neo- $\left.\mathbf{N H}_{3}{ }^{+} \mathbf{T F A}^{-}\right)_{32}$ in $0.1 \mathrm{M} \mathrm{pH} 7.4$ potassium phosphate buffer, trial 1

\begin{tabular}{|c|c|c|c|c|c|c|}
\hline \multicolumn{7}{|c|}{ Neopentyl Periphery pH 7.4} \\
\hline $\begin{array}{l}\text { Time } \\
\text { (days) }\end{array}$ & $\begin{array}{c}\text { Dendron- } \\
\text { bound amine } \\
\text { (s, } 2.96 \text { ppm), } \\
\text { (Int. vs. } \\
\text { HCOONa) }\end{array}$ & $\begin{array}{c}\text { Aminolysis; } \\
\delta- \\
\text { valerolactam } \\
\text { (t, } 3.26 \text { ppm; } \\
\text { Int) }\end{array}$ & $\begin{array}{c}\text { Hydrolysis; } \\
5- \\
\text { aminovalerate } \\
\text { (s, 1.67 ppm; } \\
\text { Int) }\end{array}$ & $\begin{array}{l}5 \text {-aminovalerate as a } \\
(\%) \text { of total amines }\end{array}$ & $\begin{array}{l}\text { Lactam as a (\%) } \\
\text { of total amines }\end{array}$ & $\begin{array}{c}\text { Intact } \\
\text { Amines (\%) }\end{array}$ \\
\hline 0 & 0.42 & 0 & 0 & 0.00 & 0.0 & 100.0 \\
\hline 1 & 0.41 & 0 & 0 & 0.00 & 0.0 & 100.0 \\
\hline 5 & 0.41 & 0 & 0 & 0.00 & 0.0 & 100.0 \\
\hline 6 & 0.4 & 0 & 0 & 0.00 & 0.0 & 100.0 \\
\hline 7 & 0.41 & 0 & 0 & 0.00 & 0.0 & 100.0 \\
\hline 12 & 0.41 & 0 & 0 & 0.00 & 0.0 & 100.0 \\
\hline 14 & 0.4 & 0 & 0 & 0.00 & 0.0 & 100.0 \\
\hline 19 & 0.42 & 0 & 0 & 0.00 & 0.0 & 100.0 \\
\hline 25 & 0.42 & 0.01 & 0 & 0.00 & 2.3 & 97.7 \\
\hline 28 & 0.4 & 0.01 & 0 & 0.00 & 2.4 & 97.6 \\
\hline 32 & 0.39 & 0.01 & 0 & 0.00 & 2.5 & 97.5 \\
\hline
\end{tabular}

Table S11. Tracking ${ }^{1} \mathrm{H}$ NMR of BnO-G5-(Neo- $\left.\mathbf{N H}_{3}{ }^{+} \mathbf{T F A}^{-}\right)_{32}$ in $0.1 \mathrm{M} \mathrm{pH} 7.4$ potassium phosphate buffer, trial 2

\begin{tabular}{|c|c|c|c|c|c|c|}
\hline \multicolumn{7}{|c|}{ Neopentyl Periphery pH 7.4} \\
\hline $\begin{array}{l}\text { Time } \\
\text { (days) }\end{array}$ & $\begin{array}{c}\text { Dendron- } \\
\text { bound amine } \\
\text { (s, } 2.96 \text { ppm), } \\
\text { (Int. vs. } \\
\text { HCOONa) }\end{array}$ & $\begin{array}{c}\text { Aminolysis; } \\
\delta- \\
\text { valerolactam } \\
\text { (t, } 3.26 \text { ppm; } \\
\text { Int) }\end{array}$ & $\begin{array}{c}\text { Hydrolysis; } \\
5- \\
\text { aminovalerate } \\
\text { (s, 1.6 ppm; } \\
\text { Int) }\end{array}$ & $\begin{array}{l}\text { 5-aminovalerate as a } \\
(\%) \text { of total amines }\end{array}$ & $\begin{array}{l}\text { Lactam as a (\%) } \\
\text { of total amines }\end{array}$ & $\begin{array}{c}\text { Intact } \\
\text { Amines (\%) }\end{array}$ \\
\hline 0 & 0.16 & 0 & 0 & 0 & 0.0 & 100.0 \\
\hline 1 & 0.18 & 0 & 0 & 0 & 0.0 & 100.0 \\
\hline 5 & 0.17 & 0 & 0 & 0 & 0.0 & 100.0 \\
\hline
\end{tabular}




\begin{tabular}{|r|r|r|r|r|r|r|}
6 & 0.17 & 0 & 0 & 0 & 0.0 & 100.0 \\
\hline 7 & 0.18 & 0 & 0 & 0 & 0.0 & 100.0 \\
\hline 12 & 0.18 & 0.01 & 0 & 0 & 5.3 & 94.7 \\
\hline 14 & 0.18 & 0.01 & 0 & 0 & 5.3 & 94.7 \\
\hline 19 & 0.17 & 0.01 & 0 & 0 & 5.6 & 94.4 \\
\hline 25 & 0.17 & 0.01 & 0 & 0 & 5.6 & 94.4 \\
\hline 28 & 0.17 & 0.01 & 0 & 0 & 5.6 & 94.4 \\
\hline 32 & 0.17 & 0.01 & 0 & 0 & 5.6 & 94.4 \\
\hline
\end{tabular}

Table S12. Tracking ${ }^{1} \mathrm{H}$ NMR of BnO-G5-(Neo- $\left.\mathbf{N H}_{3}{ }^{+} \mathbf{T F A}^{-}\right)_{32}$ in $0.1 \mathrm{M} \mathrm{pH} 7.4$ potassium phosphate buffer, trial 3.

\begin{tabular}{|c|c|c|c|c|c|c|}
\hline \multicolumn{7}{|c|}{ Neopentyl Periphery pH 7.4} \\
\hline $\begin{array}{l}\text { Time } \\
\text { (days) }\end{array}$ & $\begin{array}{c}\text { Dendron- } \\
\text { bound amine } \\
\text { (s, } 2.96 \text { ppm), } \\
\text { (Int. vs. } \\
\text { HCOONa) }\end{array}$ & $\begin{array}{c}\text { Aminolysis; } \\
\delta- \\
\text { valerolactam } \\
\text { (t, } 3.26 \text { ppm; } \\
\text { Int) }\end{array}$ & $\begin{array}{c}\text { Hydrolysis; } \\
5- \\
\text { aminovalerate } \\
\text { (s, 1.6 ppm; } \\
\text { Int) }\end{array}$ & $\begin{array}{l}\text { 5-aminovalerate as a } \\
(\%) \text { of total amines }\end{array}$ & $\begin{array}{l}\text { Lactam as a (\%) } \\
\text { of total amines }\end{array}$ & $\begin{array}{c}\text { Intact } \\
\text { Amines (\%) }\end{array}$ \\
\hline 0 & 0.18 & 0 & 0 & 0.0 & 0.0 & 100.0 \\
\hline 1 & 0.18 & 0 & 0 & 0.0 & 0.0 & 100.0 \\
\hline 5 & 0.18 & 0 & 0 & 0.0 & 0.0 & 100.0 \\
\hline 6 & 0.18 & 0 & 0 & 0.0 & 0.0 & 100.0 \\
\hline 7 & 0.18 & 0 & 0 & 0.0 & 0.0 & 100.0 \\
\hline 12 & 0.18 & 0.01 & 0 & 0.0 & 5.3 & 94.7 \\
\hline 14 & 0.17 & 0.01 & 0 & 0.0 & 5.6 & 94.4 \\
\hline 19 & 0.17 & 0.01 & 0 & 0.0 & 5.6 & 94.4 \\
\hline 25 & 0.17 & 0.01 & 0 & 0.0 & 5.6 & 94.4 \\
\hline 28 & 0.17 & 0.01 & 0 & 0.0 & 5.6 & 94.4 \\
\hline 32 & 0.17 & 0.01 & 0 & 0.0 & 5.6 & 94.4 \\
\hline
\end{tabular}


Table S13. Tracking ${ }^{1} \mathrm{H}$ NMR of BnO-G5-(Lin- $\left.\mathbf{N H}_{3}{ }^{+} \mathbf{T F A}^{-}\right)_{32}$ in $0.1 \mathrm{M} \mathrm{pH} 8$ potassium phosphate buffer, trial 1

\begin{tabular}{|c|c|c|c|c|c|c|}
\hline \multicolumn{7}{|c|}{$f$} \\
\hline $\begin{array}{l}\text { Time } \\
\text { (days) }\end{array}$ & $\begin{array}{c}\text { Dendron- } \\
\text { bound amine } \\
\text { (t, } 2.45 \text { ppm), } \\
\text { (Int. vs. } \\
\text { HCOONa) }\end{array}$ & $\begin{array}{c}\text { Aminolysis; } \\
\delta- \\
\text { valerolactam } \\
\text { (t, 2.31 ppm; } \\
\text { Int) }\end{array}$ & $\begin{array}{c}\text { Hydrolysis; } \\
5- \\
\text { aminovalerate } \\
\text { (s, } 1.6 \text { ppm; } \\
\text { Int) }\end{array}$ & $\begin{array}{l}\text { 5-aminovalerate as a } \\
(\%) \text { of total amines }\end{array}$ & $\begin{array}{c}\text { Lactam as a (\%) } \\
\text { of total amines }\end{array}$ & $\begin{array}{c}\text { Intact } \\
\text { Amines (\%) }\end{array}$ \\
\hline 0 & 0.61 & 0 & 0.00 & 0.00 & 0.0 & 100 \\
\hline 4 & 0.41 & 0.17 & 0.04 & 6.45 & 27.4 & 66.1 \\
\hline 6 & 0.37 & 0.21 & 0.05 & 7.94 & 33.3 & 58.7 \\
\hline 12 & 0.30 & 0.24 & 0.06 & 10.00 & 40.0 & 50.0 \\
\hline 14 & 0.31 & 0.27 & 0.08 & 12.12 & 40.9 & 47.0 \\
\hline 25 & 0.24 & 0.30 & 0.09 & 14.29 & 47.6 & 38.1 \\
\hline 29 & 0.22 & 0.3 & 0.09 & 14.75 & 49.2 & 36.1 \\
\hline
\end{tabular}

Table S14. Tracking ${ }^{1} \mathrm{H}$ NMR of BnO-G5-(Lin- $\left.\mathbf{N H}_{3}{ }^{+} \mathbf{T F A}^{-}\right)_{32}$ in $0.1 \mathrm{M} \mathrm{pH} 8$ potassium phosphate buffer, trial 2

\begin{tabular}{|c|c|c|c|c|c|c|}
\hline \multicolumn{7}{|c|}{ Linear Periphery, pH 8.0} \\
\hline $\begin{array}{l}\text { Time } \\
\text { (days) }\end{array}$ & $\begin{array}{c}\text { Dendron- } \\
\text { bound amine } \\
\text { (t, } 2.45 \text { ppm), } \\
\text { (Int. vs. } \\
\text { HCOONa) }\end{array}$ & $\begin{array}{c}\text { Aminolysis; } \\
\text { ס- } \\
\text { valerolactam } \\
\text { (t, 2.31 ppm; } \\
\text { Int) }\end{array}$ & $\begin{array}{c}\text { Hydrolysis; } \\
5- \\
\text { aminovalerate } \\
\text { (s, 1.6 ppm; } \\
\text { Int) }\end{array}$ & $\begin{array}{l}\text { 5-aminovalerate as a } \\
(\%) \text { of total amines }\end{array}$ & $\begin{array}{c}\text { Lactam as a (\%) } \\
\text { of total amines }\end{array}$ & $\begin{array}{c}\text { Intact } \\
\text { Amines (\%) }\end{array}$ \\
\hline 0 & 0.49 & 0 & 0.00 & 0.00 & 0.0 & 100 \\
\hline 4 & 0.41 & 0.07 & 0.03 & 5.88 & 13.7 & 80.4 \\
\hline 6 & 0.37 & 0.12 & 0.05 & 9.26 & 22.2 & 68.5 \\
\hline 12 & 0.31 & 0.18 & 0.07 & 12.50 & 32.1 & 55.4 \\
\hline 14 & 0.3 & 0.17 & 0.07 & 12.96 & 31.5 & 55.6 \\
\hline
\end{tabular}




\begin{tabular}{|r|r|r|r|r|r|r|}
25 & 0.26 & 0.2 & 0.08 & 14.81 & 37.0 \\
\hline 29 & 0.21 & 0.23 & 0.09 & 16.98 & 48.1 \\
\hline
\end{tabular}

Table S15. Tracking ${ }^{1} \mathrm{H}$ NMR of BnO-G5-(Lin- $\left.\mathbf{N H}_{3}{ }^{+} \mathbf{T F A}^{-}\right)_{32}$ in $0.1 \mathrm{M} \mathrm{pH} 8$ potassium phosphate buffer, trial 3

\begin{tabular}{|c|c|c|c|c|c|c|}
\hline \multicolumn{7}{|c|}{ Linear Periphery, pH 8.0} \\
\hline $\begin{array}{l}\text { Time } \\
\text { (days) }\end{array}$ & $\begin{array}{c}\text { Dendron- } \\
\text { bound amine } \\
\text { (t, } 2.45 \text { ppm), } \\
\text { (Int. vs. } \\
\text { HCOONa) }\end{array}$ & $\begin{array}{c}\text { Aminolysis; } \\
\text { ס- } \\
\text { valerolactam } \\
\text { (t, 2.31 ppm; } \\
\text { Int) }\end{array}$ & $\begin{array}{c}\text { Hydrolysis; } \\
5- \\
\text { aminovalerate } \\
\text { (s, 1.6 ppm; } \\
\text { Int) }\end{array}$ & $\begin{array}{l}\text { 5-aminovalerate as a } \\
(\%) \text { of total amines }\end{array}$ & $\begin{array}{l}\text { Lactam as a (\%) } \\
\text { of total amines }\end{array}$ & $\begin{array}{c}\text { Intact } \\
\text { Amines (\%) }\end{array}$ \\
\hline 0 & 0.6 & 0 & 0.00 & 0.00 & 0.0 & 100 \\
\hline 4 & 0.43 & 0.17 & 0.04 & 6.25 & 26.6 & 67.2 \\
\hline 6 & 0.38 & 0.2 & 0.05 & 7.94 & 31.7 & 60.3 \\
\hline 12 & 0.33 & 0.25 & 0.07 & 10.77 & 38.5 & 50.8 \\
\hline 14 & 0.31 & 0.26 & 0.07 & 10.94 & 40.6 & 48.4 \\
\hline 25 & 0.24 & 0.29 & 0.09 & 14.52 & 46.8 & 38.7 \\
\hline 29 & 0.23 & 0.3 & 0.09 & 14.52 & 48.4 & 37.1 \\
\hline
\end{tabular}

Table S16. Tracking ${ }^{1} \mathrm{H}$ NMR of BnO-G5-(Neo- $\left.\mathbf{N H}_{3}{ }^{+} \mathbf{T F A}^{-}\right)_{32}$ in $0.1 \mathrm{M} \mathrm{pH} 8$ potassium phosphate buffer, trial 1

\begin{tabular}{|c|c|c|c|c|c|c|}
\hline \multicolumn{7}{|c|}{ Neopentyl Periphery pH 8} \\
\hline $\begin{array}{l}\text { Time } \\
\text { (days) }\end{array}$ & $\begin{array}{c}\text { Dendron- } \\
\text { bound amine } \\
\text { (s, } 2.96 \text { ppm), } \\
\text { (Int. vs. } \\
\text { HCOONa) }\end{array}$ & $\begin{array}{c}\text { Aminolysis; } \\
\text { ס- } \\
\text { valerolactam } \\
\text { (t, } 3.26 \text { ppm; } \\
\text { Int) }\end{array}$ & $\begin{array}{c}\text { Hydrolysis; } \\
5- \\
\text { aminovalerate } \\
\text { (s, } 1.6 \text { ppm; } \\
\text { Int) }\end{array}$ & $\begin{array}{l}\text { 5-aminovalerate as a } \\
(\%) \text { of total amines }\end{array}$ & $\begin{array}{l}\text { Lactam as a (\%) } \\
\text { of total amines }\end{array}$ & $\begin{array}{c}\text { Intact } \\
\text { Amines (\%) }\end{array}$ \\
\hline 0 & 0.37 & 0 & 0 & 0 & 0.0 & 100.0 \\
\hline 1 & 0.36 & 0 & 0 & 0 & 0.0 & 100.0 \\
\hline 5 & 0.36 & 0.01 & 0 & 0 & 2.7 & 97.3 \\
\hline
\end{tabular}




\begin{tabular}{|r|r|r|r|r|r|r|}
\hline 6 & 0.36 & 0.01 & 0 & 0 & 2.7 & 97.3 \\
\hline 7 & 0.36 & 0.01 & 0 & 0 & 2.7 & 97.3 \\
\hline 12 & 0.36 & 0.01 & 0 & 0 & 2.7 & 97.3 \\
\hline 14 & 0.35 & 0.01 & 0 & 0 & 2.8 & 97.2 \\
\hline 19 & 0.35 & 0.02 & 0 & 0 & 5.4 & 94.6 \\
\hline 25 & 0.35 & 0.02 & 0 & 0 & 5.4 & 94.6 \\
\hline 28 & 0.35 & 0.02 & 0 & 0 & 5.4 & 94.6 \\
\hline 32 & 0.35 & 0.02 & 0 & 0 & 5.4 & 94.6 \\
\hline
\end{tabular}

Table S17. Tracking ${ }^{1} \mathrm{H}$ NMR of BnO-G5-(Neo- $\left.\mathbf{N H}_{3}{ }^{+} \mathbf{T F A}^{-}\right)_{32}$ in $0.1 \mathrm{M} \mathrm{pH} 8$ potassium phosphate buffer, trial 2

\begin{tabular}{|c|c|c|c|c|c|c|}
\hline \multicolumn{7}{|c|}{ neo pH 8} \\
\hline $\begin{array}{l}\text { Time } \\
\text { (days) }\end{array}$ & $\begin{array}{c}\text { Dendron- } \\
\text { bound amine } \\
\text { (s, } 2.96 \text { ppm), } \\
\text { (Int. vs. } \\
\text { HCOONa) }\end{array}$ & $\begin{array}{c}\text { Aminolysis; } \\
\delta- \\
\text { valerolactam } \\
\text { (t, } 3.26 \text { ppm; } \\
\text { Int) }\end{array}$ & $\begin{array}{c}\text { Hydrolysis; } \\
5- \\
\text { aminovalerate } \\
\text { (s, 1.6 ppm; } \\
\text { Int) }\end{array}$ & $\begin{array}{l}5 \text {-aminovalerate as a } \\
(\%) \text { of total amines }\end{array}$ & $\begin{array}{l}\text { Lactam as a (\%) } \\
\text { of total amines }\end{array}$ & $\begin{array}{c}\text { Intact } \\
\text { Amines (\%) }\end{array}$ \\
\hline 0 & 0.16 & 0 & 0 & 0 & 0.0 & 100.0 \\
\hline 1 & 0.16 & 0 & 0 & 0 & 0.0 & 100.0 \\
\hline 5 & 0.16 & 0.01 & 0 & 0 & 5.9 & 94.1 \\
\hline 6 & 0.15 & 0.01 & 0 & 0 & 6.3 & 93.8 \\
\hline 7 & 0.16 & 0.01 & 0 & 0 & 5.9 & 94.1 \\
\hline 12 & 0.15 & 0.02 & 0 & 0 & 11.8 & 88.2 \\
\hline 14 & 0.15 & 0.02 & 0 & 0 & 11.8 & 88.2 \\
\hline 19 & 0.14 & 0.02 & 0 & 0 & 12.5 & 87.5 \\
\hline 25 & 0.15 & 0.03 & 0 & 0 & 16.7 & 83.3 \\
\hline 28 & 0.14 & 0.03 & 0 & 0 & 17.6 & 82.4 \\
\hline 32 & 0.14 & 0.03 & 0 & 0 & 17.6 & 82.4 \\
\hline
\end{tabular}


Table S18. Tracking ${ }^{1} \mathrm{H}$ NMR of BnO-G5-(Neo- $\left.\mathbf{N H}_{3}{ }^{+} \mathbf{T F A}^{-}\right)_{32}$ in $0.1 \mathrm{M} \mathrm{pH} 8$ potassium phosphate buffer, trial 3

\begin{tabular}{|c|c|c|c|c|c|c|}
\hline \multicolumn{7}{|c|}{ neo pH 8} \\
\hline $\begin{array}{l}\text { Time } \\
\text { (days) }\end{array}$ & $\begin{array}{c}\text { Dendron- } \\
\text { bound amine } \\
\text { (s, } 2.96 \text { ppm), } \\
\text { (Int. vs. } \\
\text { HCOONa) }\end{array}$ & $\begin{array}{c}\text { Aminolysis; } \\
\text { ठ- } \\
\text { valerolactam } \\
\text { (t, } 3.26 \text { ppm; } \\
\text { Int) }\end{array}$ & $\begin{array}{c}\text { Hydrolysis; } \\
5- \\
\text { aminovalerate } \\
\text { (s, } 1.6 \text { ppm; } \\
\text { Int) }\end{array}$ & $\begin{array}{c}\text { 5-aminovalerate as a } \\
(\%) \text { of total amines }\end{array}$ & $\begin{array}{l}\text { Lactam as a (\%) } \\
\text { of total amines }\end{array}$ & $\begin{array}{c}\text { Intact } \\
\text { Amines (\%) }\end{array}$ \\
\hline 0 & 0.17 & 0 & 0 & 0.0 & 0.0 & 100.0 \\
\hline 1 & 0.17 & 0 & 0 & 0.0 & 0.0 & 100.0 \\
\hline 5 & 0.17 & 0.01 & 0 & 0.0 & 5.6 & 94.4 \\
\hline 6 & 0.16 & 0.01 & 0 & 0.0 & 5.9 & 94.1 \\
\hline 7 & 0.17 & 0.01 & 0 & 0.0 & 5.6 & 94.4 \\
\hline 12 & 0.16 & 0.01 & 0 & 0.0 & 5.9 & 94.1 \\
\hline 14 & 0.16 & 0.02 & 0 & 0.0 & 11.1 & 88.9 \\
\hline 19 & 0.15 & 0.02 & 0 & 0.0 & 11.8 & 88.2 \\
\hline 25 & 0.15 & 0.02 & 0 & 0.0 & 11.8 & 88.2 \\
\hline 28 & 0.15 & 0.03 & 0 & 0.0 & 16.7 & 83.3 \\
\hline 32 & 0.15 & 0.03 & 0 & 0.0 & 16.7 & 83.3 \\
\hline
\end{tabular}




\section{Esterase Degradation Studies}

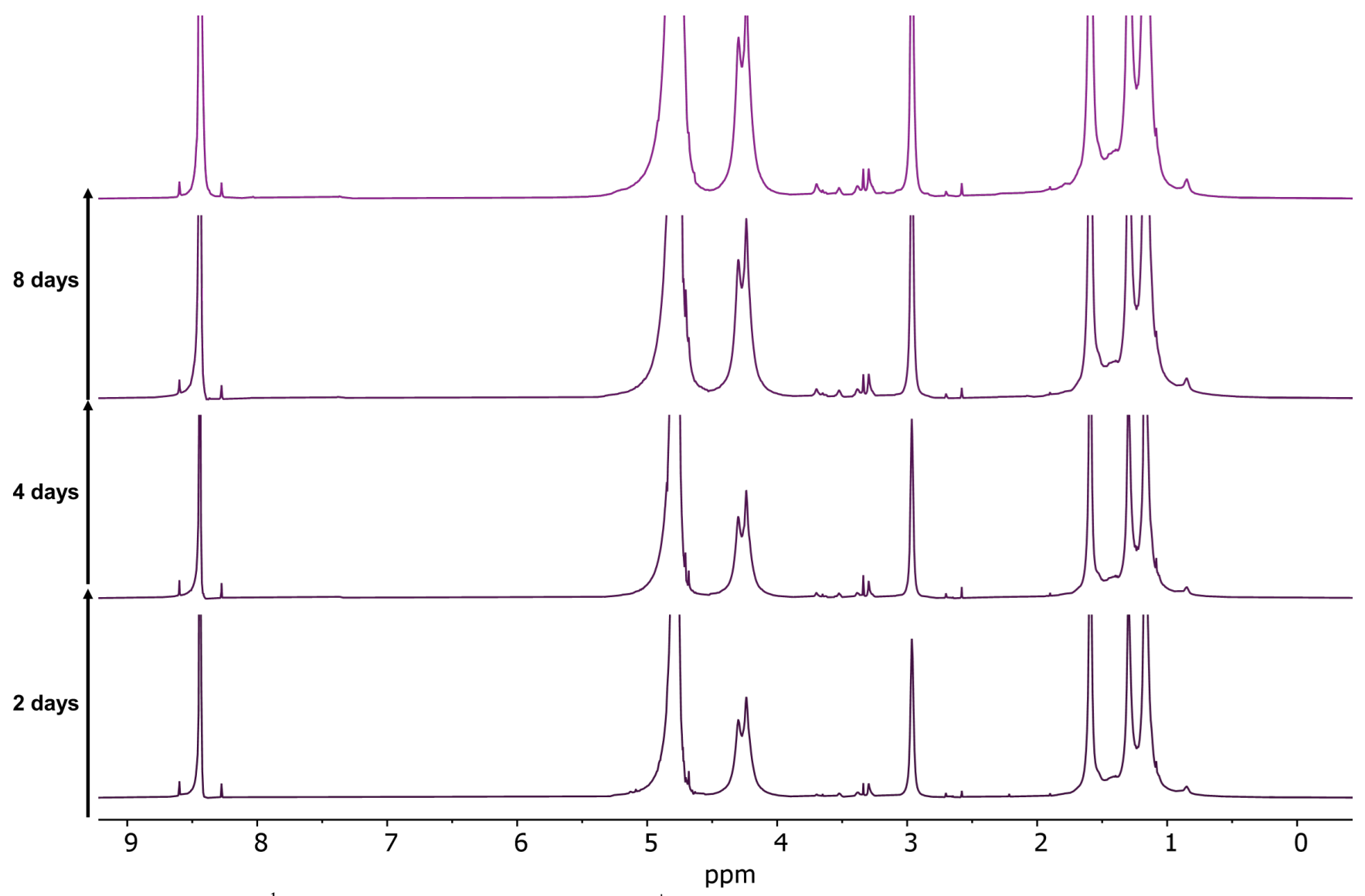

Figure S10. Tracking ${ }^{1} \mathrm{H}$ NMR of BnO-G5-(Neo- $\left.\mathbf{N H}_{3}{ }^{+} \mathbf{T F A}^{-}\right)_{32}$ in $20 \%$ mol eq. (vs. amine group) esterase in 0.1 $\mathrm{M} \mathrm{pH} 7.4$ potassium phosphate buffer. 


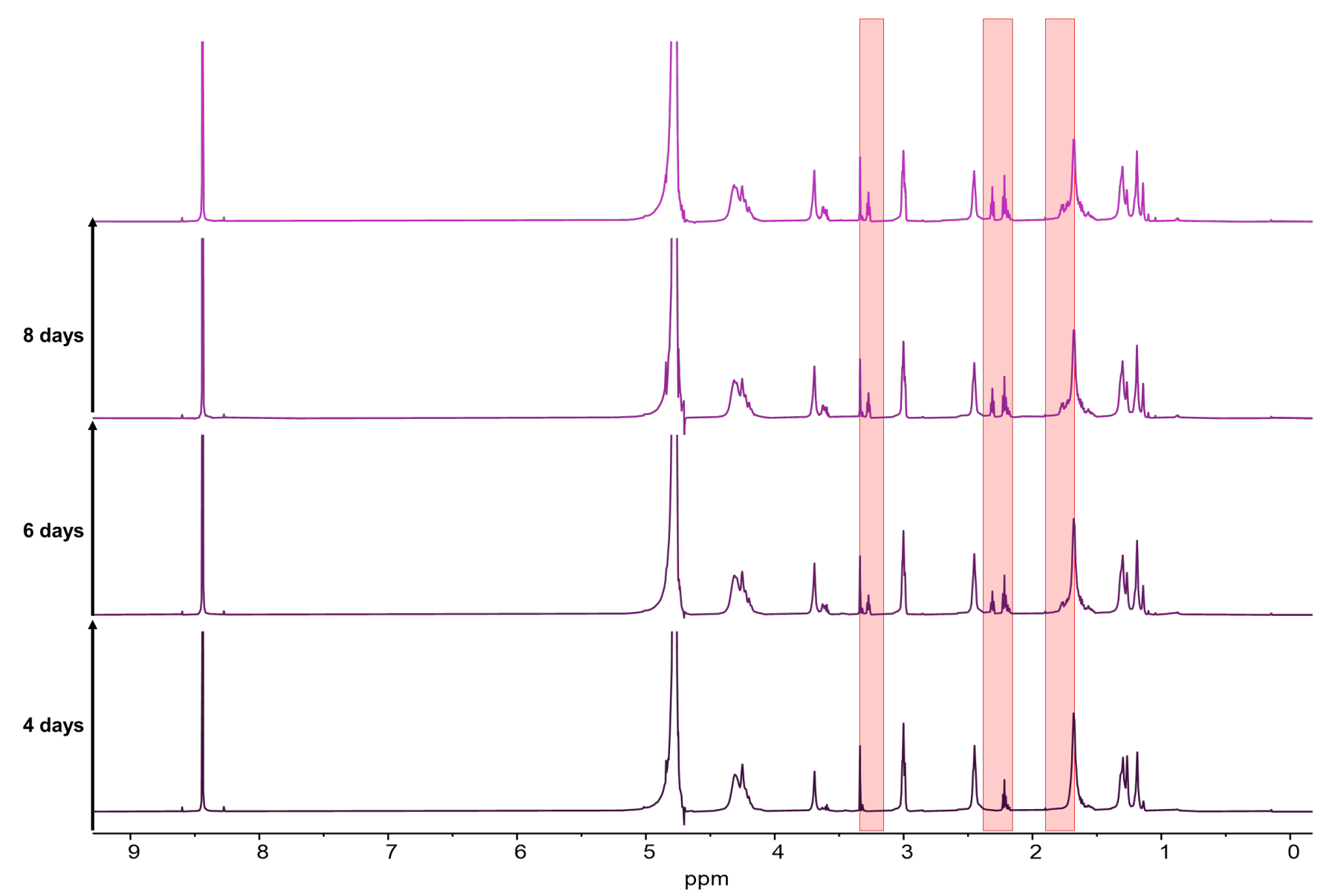

Figure S11. Tracking ${ }^{1} \mathrm{H}$ NMR of BnO-G5-(Lin-NH3 $\left.{ }^{+} \mathbf{T F A}^{-}\right)_{32}$ in $20 \% \mathrm{~mol}$ eq. (vs. amine group) esterase in $0.1 \mathrm{M}$ $\mathrm{pH} 7.4$ potassium phosphate buffer. Boxed signals are of the hydrolyzed ammonium-containing valeric acid.

Table S19. Tracking ${ }^{1} \mathrm{H}$ NMR of BnO-G5-(Lin- $\left.\mathbf{N H}_{3}{ }^{+} \mathbf{T F A}^{-}\right)_{32}$ in $20 \%$ esterase in $0.1 \mathrm{M} \mathrm{pH} 7.4$ potassium phosphate buffer, trial 1.

\begin{tabular}{|c|c|c|c|c|c|c|}
\hline \multicolumn{7}{|c|}{ Linear Periphery, esterase } \\
\hline $\begin{array}{l}\text { Time } \\
\text { (days) }\end{array}$ & $\begin{array}{c}\text { Dendron- } \\
\text { bound } \\
\text { amine } \\
\text { (t, } 2.45 \\
\text { ppm), } \\
\text { (Int. vs. } \\
\text { HCOONa) }\end{array}$ & $\begin{array}{c}\text { Aminolysis; } \\
\delta- \\
\text { valerolactam } \\
\text { (t, 2.31 ppm; } \\
\text { Int) }\end{array}$ & $\begin{array}{c}\text { Hydrolysis; } \\
5- \\
\text { aminovalerate } \\
\text { (t, 2.2 ppm; } \\
\text { Int) }\end{array}$ & $\begin{array}{c}5- \\
\text { aminovalerate } \\
\text { as a }(\%) \text { of } \\
\text { total amines }\end{array}$ & $\begin{array}{c}\text { Lactam } \\
\text { as a (\%) } \\
\text { of total } \\
\text { amines }\end{array}$ & $\begin{array}{c}\text { Intact } \\
\text { Amines } \\
(\%)\end{array}$ \\
\hline 0 & 0.75 & 0 & 0.00 & 0.0 & 0.0 & 100.0 \\
\hline 4 & 0.62 & 0.1 & 0.05 & 6.5 & 13.0 & 80.5 \\
\hline 6 & 0.58 & 0.12 & 0.05 & 6.7 & 16.0 & 77.3 \\
\hline 8 & 0.54 & 0.14 & 0.05 & 6.8 & 19.2 & 74.0 \\
\hline
\end{tabular}

Table S20. Tracking ${ }^{1} \mathrm{H}$ NMR of BnO-G5-(Lin- $\left.\mathbf{N H}_{3}{ }^{+} \mathbf{T F A}^{-}\right)_{32}$ in $20 \%$ esterase in $0.1 \mathrm{M} \mathrm{pH} 7.4$ potassium phosphate buffer, trial 2 


\begin{tabular}{|c|c|c|c|c|c|c|}
\hline $\begin{array}{l}\text { Time } \\
\text { (days) }\end{array}$ & $\begin{array}{l}\text { Dendron- } \\
\text { bound } \\
\text { amine } \\
\text { (t, } 2.45 \\
\text { ppm), } \\
\text { (Int. vs. } \\
\text { HCOONa) }\end{array}$ & $\begin{array}{c}\text { Aminolysis; } \\
\delta- \\
\text { valerolactam } \\
\text { (t, 2.31 ppm; } \\
\text { Int) }\end{array}$ & $\begin{array}{c}\text { Hydrolysis; } \\
5- \\
\text { aminovalerate } \\
\text { (t, 2.2 ppm; } \\
\text { Int) }\end{array}$ & $\begin{array}{c}5- \\
\text { aminovalerate } \\
\text { as a }(\%) \text { of } \\
\text { total amines }\end{array}$ & $\begin{array}{l}\text { Lactam } \\
\text { as a }(\%) \\
\text { of total } \\
\text { amines }\end{array}$ & $\begin{array}{c}\text { Intact } \\
\text { Amines } \\
(\%)\end{array}$ \\
\hline 0 & 0.91 & 0 & 0.00 & 0.0 & 0.0 & 100.0 \\
\hline 4 & 0.84 & 0.1 & 0.05 & 5.1 & 10.1 & 84.8 \\
\hline 6 & 0.80 & 0.14 & 0.08 & 7.8 & 13.7 & 78.4 \\
\hline 8 & 0.77 & 0.14 & 0.07 & 7.1 & 14.3 & 78.6 \\
\hline
\end{tabular}

Table S21. Tracking ${ }^{1} \mathrm{H}$ NMR of BnO-G5-(Lin- $\left.\mathbf{N H}_{3}{ }^{+} \mathbf{T F A}^{-}\right)_{32}$ in $20 \%$ esterase in $0.1 \mathrm{M} \mathrm{pH} 7.4$ potassium phosphate buffer, trial 3

\begin{tabular}{|c|c|c|c|c|c|c|}
\hline \multicolumn{7}{|c|}{ Linear Periphery, esterase 2} \\
\hline $\begin{array}{l}\text { Time } \\
\text { (days) }\end{array}$ & $\begin{array}{c}\text { Dendron- } \\
\text { bound } \\
\text { amine } \\
\text { (t, } 2.45 \\
\text { ppm), } \\
\text { (Int. vs. } \\
\text { HCOONa) }\end{array}$ & $\begin{array}{c}\text { Aminolysis; } \\
\delta- \\
\text { valerolactam } \\
\text { (t, 2.31 ppm; } \\
\text { Int) }\end{array}$ & $\begin{array}{c}\text { Hydrolysis; } \\
5- \\
\text { aminovalerate } \\
\text { (t, 2.2 ppm; } \\
\text { Int) }\end{array}$ & $\begin{array}{c}5- \\
\text { aminovalerate } \\
\text { as a }(\%) \text { of } \\
\text { total amines }\end{array}$ & $\begin{array}{c}\text { Lactam } \\
\text { as a (\%) } \\
\text { of total } \\
\text { amines }\end{array}$ & $\begin{array}{c}\text { Intact } \\
\text { Amines } \\
(\%)\end{array}$ \\
\hline 0 & 0.79 & 0 & 0.00 & 0.0 & 0.0 & 100.0 \\
\hline 4 & 0.69 & 0.1 & 0.05 & 6.0 & 11.9 & 82.1 \\
\hline 6 & 0.65 & 0.15 & 0.07 & 8.0 & 17.2 & 74.7 \\
\hline 8 & 0.63 & 0.15 & 0.07 & 8.2 & 17.6 & 74.1 \\
\hline
\end{tabular}

Table S22. Tracking ${ }^{1} \mathrm{H}$ NMR of BnO-G5-(Neo- $\left.\mathbf{N H}_{3}{ }^{+} \mathbf{T F A}^{-}\right)_{32}$ in $20 \%$ esterase in $0.1 \mathrm{M} \mathrm{pH} 7.4$ potassium phosphate buffer, trial 1

\begin{tabular}{|r|c|r|r|r|r|r|}
\hline \multicolumn{7}{|c|}{ Neopentyl Periphery, esterase } \\
\hline & $\begin{array}{c}\text { Dendron- } \\
\text { bound } \\
\text { amine } \\
\text { (s, 2.96 } \\
\text { ppm), } \\
\text { (Int. vs. } \\
\text { HCOONa) }\end{array}$ & $\begin{array}{c}\text { Aminolysis; } \\
\text { ס- } \\
\text { valerolactam } \\
\text { (t, 3.26 ppm; } \\
\text { Int) }\end{array}$ & $\begin{array}{c}\text { Hydrolysis; } \\
\text { 5- } \\
\text { aminovalerate } \\
\text { (s, 1.6 ppm; } \\
\text { Int) }\end{array}$ & $\begin{array}{c}\text { 5- } \\
\text { aminovalerate } \\
\text { as a (\%) of } \\
\text { total amines }\end{array}$ & $\begin{array}{c}\text { Lactam } \\
\text { as a (\%) } \\
\text { of total } \\
\text { amines }\end{array}$ & $\begin{array}{c}\text { Intact } \\
\text { Amines } \\
\text { (\%) }\end{array}$ \\
\hline 0 & 0.37 & 0 & 0 & 0 & 0.0 & 100.0 \\
\hline 4 & 0.38 & 0 & 0 & 0 & 0.0 & 100.0 \\
\hline 6 & 0.38 & 0 & 0 & 0 & 0.0 & 100.0 \\
\hline 8 & 0.38 & 0 & 0 & 0 & 0.0 & 100.0 \\
\hline
\end{tabular}


Table S23. Tracking ${ }^{1} \mathrm{H}$ NMR of BnO-G5-(Neo- $\left.\mathbf{N H}_{3}{ }^{+} \mathbf{T F A}^{-}\right)_{32}$ in $20 \%$ esterase in $0.1 \mathrm{M} \mathrm{pH} 7.4$ potassium phosphate buffer, trial 2

\begin{tabular}{|c|c|c|c|c|c|c|}
\hline \multicolumn{7}{|c|}{ Neopentyl Periphery, esterase } \\
\hline $\begin{array}{l}\text { Time } \\
\text { (days) }\end{array}$ & $\begin{array}{l}\text { Dendron- } \\
\text { bound } \\
\text { amine } \\
\text { (s, } 2.96 \\
\text { ppm), } \\
\text { (Int. vs. } \\
\text { HCOONa) }\end{array}$ & $\begin{array}{c}\text { Aminolysis; } \\
\text { ס- } \\
\text { valerolactam } \\
\text { (t, } 3.26 \text { ppm; } \\
\text { Int) }\end{array}$ & $\begin{array}{c}\text { Hydrolysis; } \\
5- \\
\text { aminovalerate } \\
\text { (s, } 1.6 \text { ppm; } \\
\text { Int) }\end{array}$ & $\begin{array}{c}5- \\
\text { aminovalerate } \\
\text { as a (\%) of } \\
\text { total amines }\end{array}$ & $\begin{array}{c}\text { Lactam } \\
\text { as a (\%) } \\
\text { of total } \\
\text { amines }\end{array}$ & $\begin{array}{c}\text { Intact } \\
\text { Amines } \\
(\%)\end{array}$ \\
\hline 0 & 0.16 & 0 & 0 & 0 & 0.0 & 100.0 \\
\hline 4 & 0.17 & 0 & 0 & 0 & 0.0 & 100.0 \\
\hline 6 & 0.17 & 0 & 0 & 0 & 0.0 & 100.0 \\
\hline 8 & 0.17 & 0 & 0 & 0 & 0.0 & 100.0 \\
\hline
\end{tabular}

Table S24. Tracking ${ }^{1} \mathrm{H}$ NMR of BnO-G5-(Neo- $\left.\mathbf{N H}_{3}{ }^{+} \mathbf{T F A}^{-}\right)_{32}$ in $20 \%$ esterase in $0.1 \mathrm{M} \mathrm{pH} 7.4$ potassium phosphate buffer, trial 3

\begin{tabular}{|c|c|c|c|c|c|c|}
\hline \multicolumn{7}{|c|}{ Neopentyl Periphery, esterase } \\
\hline $\begin{array}{l}\text { Time } \\
\text { (days) }\end{array}$ & $\begin{array}{l}\text { Dendron- } \\
\text { bound } \\
\text { amine } \\
\text { (s, } 2.96 \\
\text { ppm), } \\
\text { (Int. vs. } \\
\text { HCOONa) }\end{array}$ & $\begin{array}{c}\text { Aminolysis; } \\
\text { ס- } \\
\text { valerolactam } \\
\text { (t, } 3.26 \text { ppm; } \\
\text { Int) }\end{array}$ & $\begin{array}{c}\text { Hydrolysis; } \\
5- \\
\text { aminovalerate } \\
\text { (s, } 1.6 \text { ppm; } \\
\text { Int) }\end{array}$ & $\begin{array}{c}5- \\
\text { aminovalerate } \\
\text { as a (\%) of } \\
\text { total amines }\end{array}$ & $\begin{array}{l}\text { Lactam } \\
\text { as a }(\%) \\
\text { of total } \\
\text { amines }\end{array}$ & $\begin{array}{c}\text { Intact } \\
\text { Amines } \\
(\%)\end{array}$ \\
\hline 0 & 0.18 & 0 & 0 & 0 & 0.0 & 100.0 \\
\hline 4 & 0.17 & 0 & 0 & 0 & 0.0 & 100.0 \\
\hline 6 & 0.18 & 0 & 0 & 0 & 0.0 & 100.0 \\
\hline 8 & 0.16 & 0 & 0 & 0 & 0.0 & 100.0 \\
\hline
\end{tabular}

\section{Product NMR Spectra}

Small Molecule NMR Data 


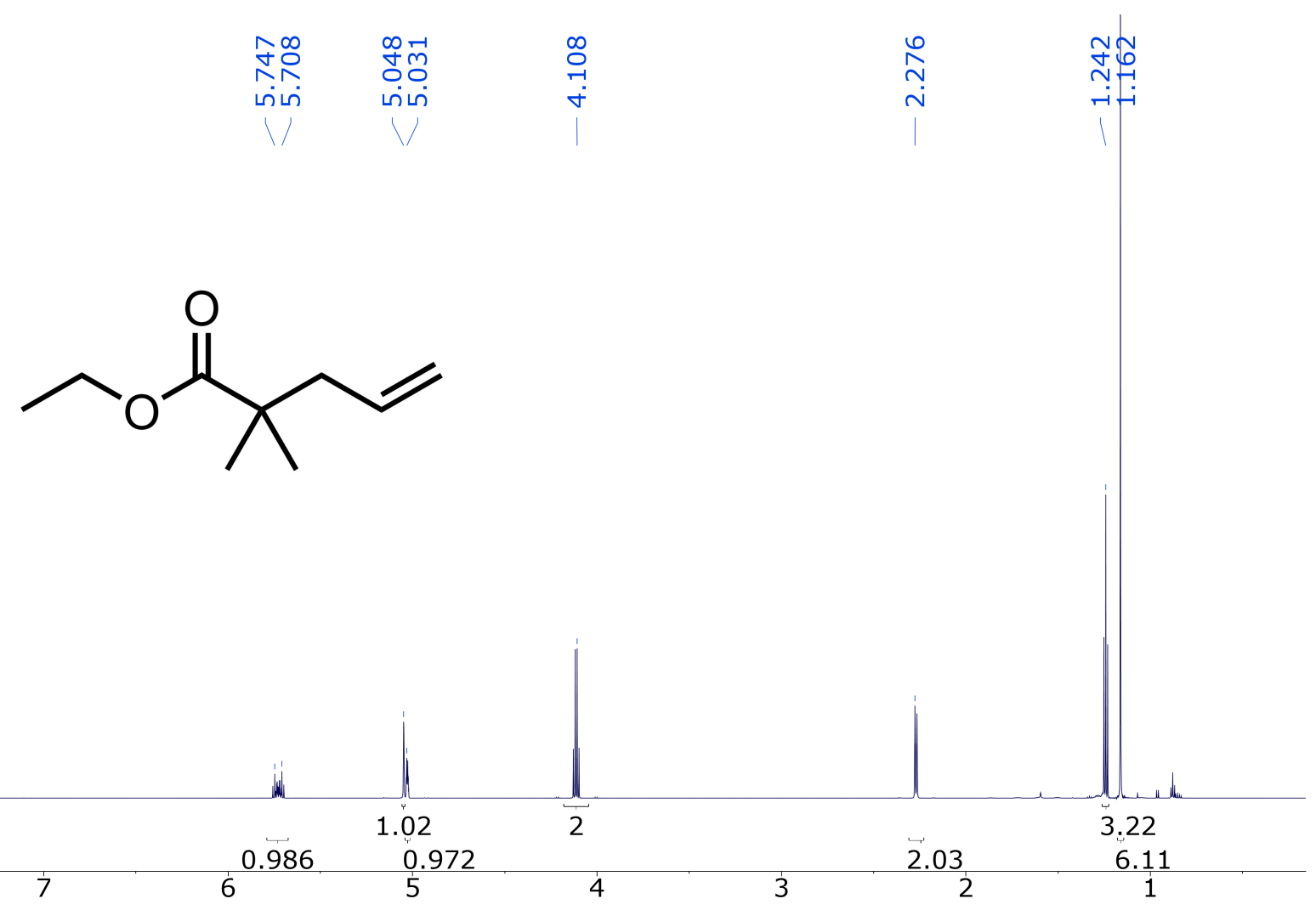

Figure S12. ${ }^{1} \mathrm{H}$ NMR spectrum of ethyl 2,2-dimethylpent-4-enoate in $\mathrm{CDCl}_{3}$.
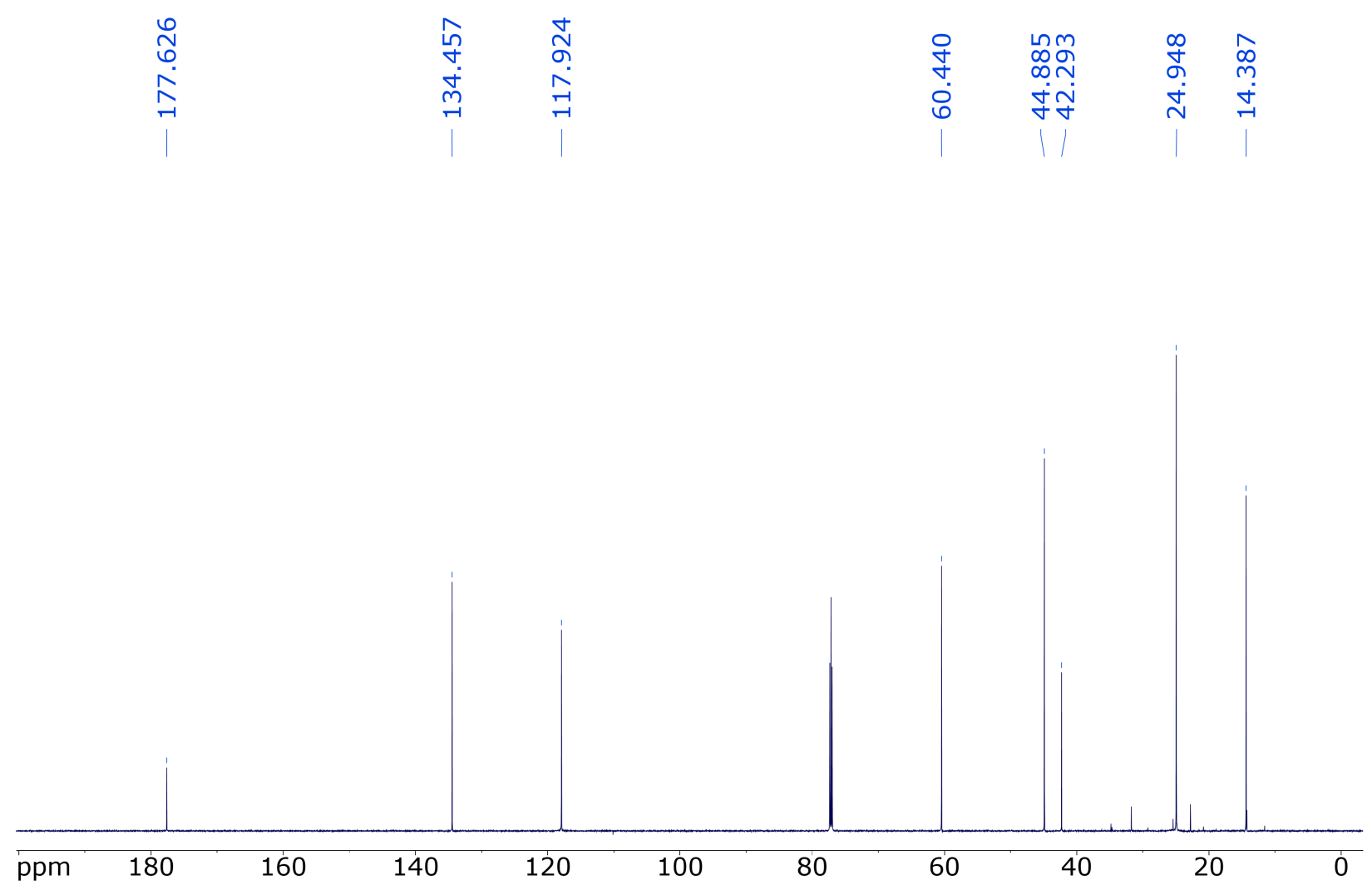

Figure S13. ${ }^{13} \mathrm{C}$ UDEFT NMR spectrum of ethyl 2,2-dimethylpent-4-enoate in $\mathrm{CDCl}_{3}$. 


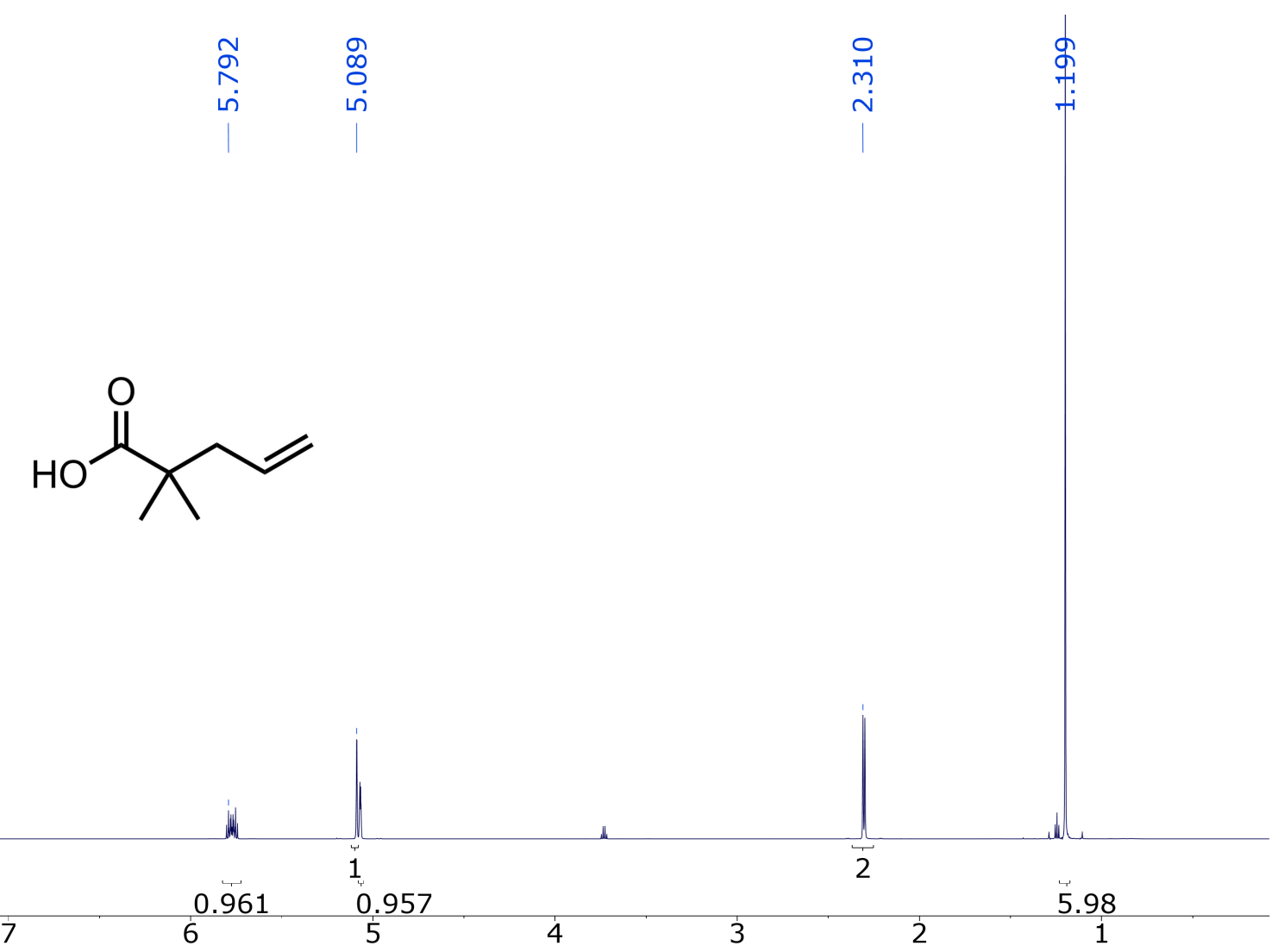

gure S14. ${ }^{1} \mathrm{H}$ NMR spectrum of ethyl 2,2-dimethylpent-4-enoic acid in $\mathrm{CDCl}_{3}$.

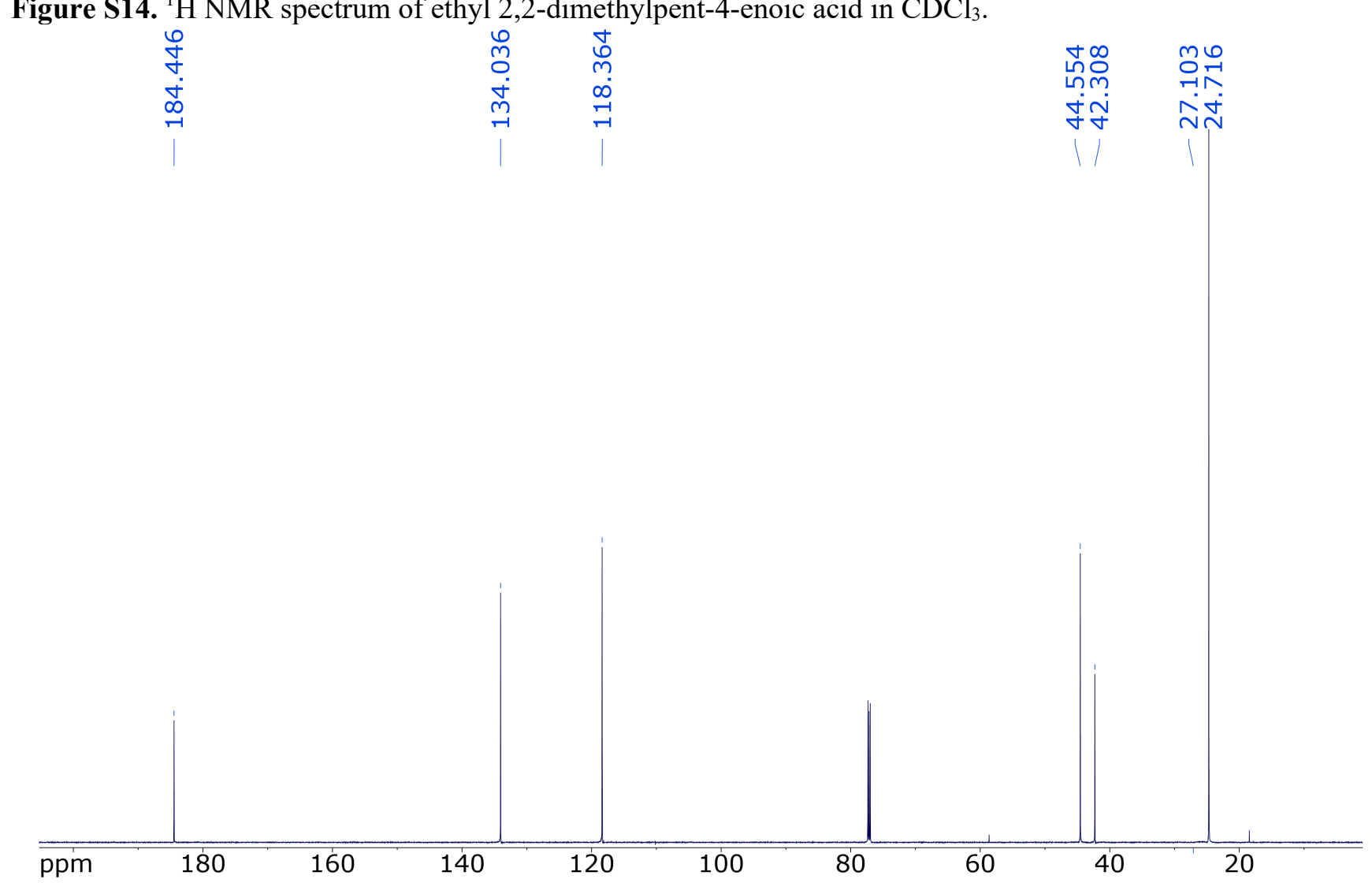

Figure S15. ${ }^{13} \mathrm{C}$ UDEFT NMR spectrum of ethyl 2,2-dimethylpent-4-enoic acid in $\mathrm{CDCl}_{3}$. 

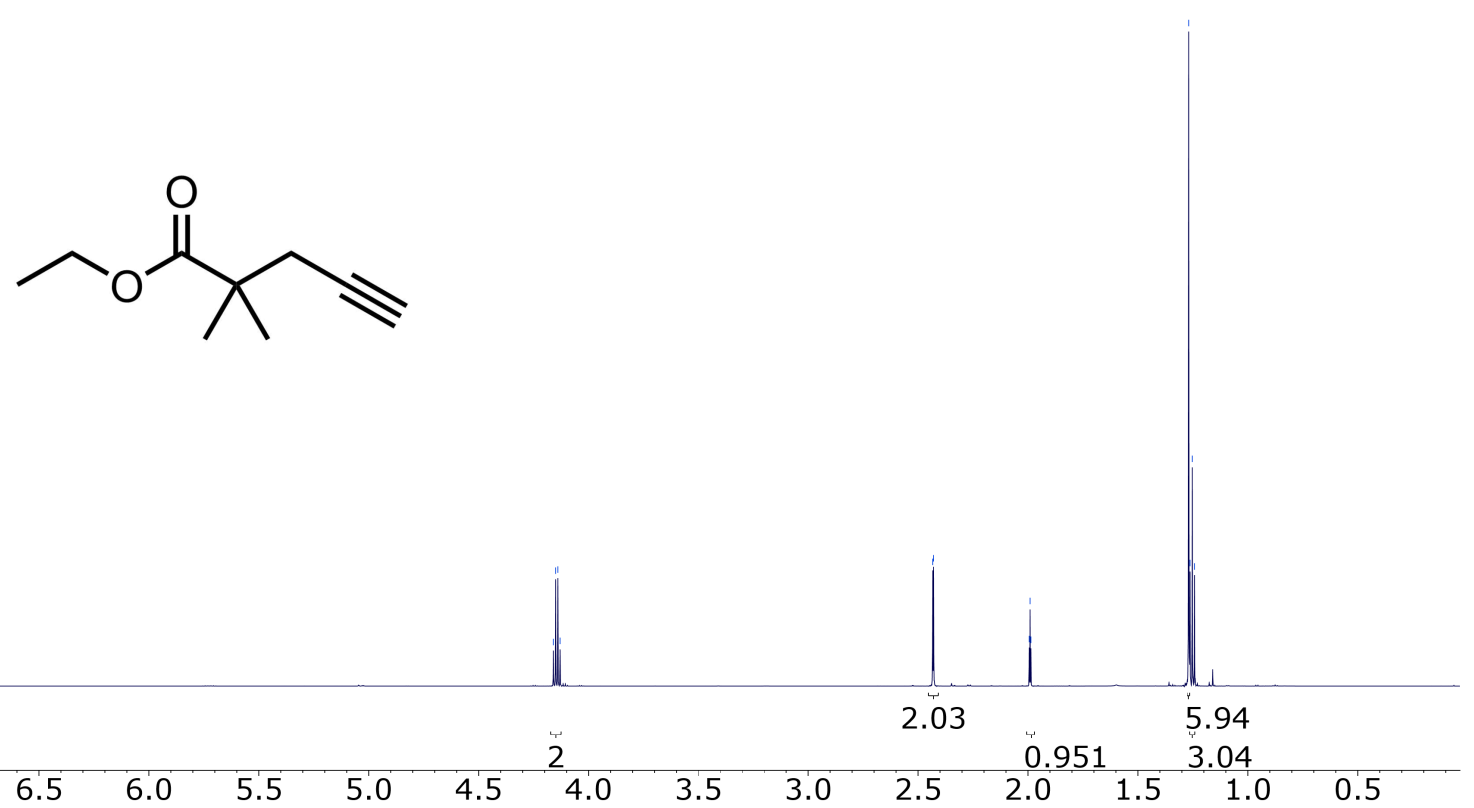

Figure S16. ${ }^{1} \mathrm{H}$ NMR spectrum of ethyl 2,2-dimethylpent-4-ynoate in $\mathrm{CDCl}_{3}$.
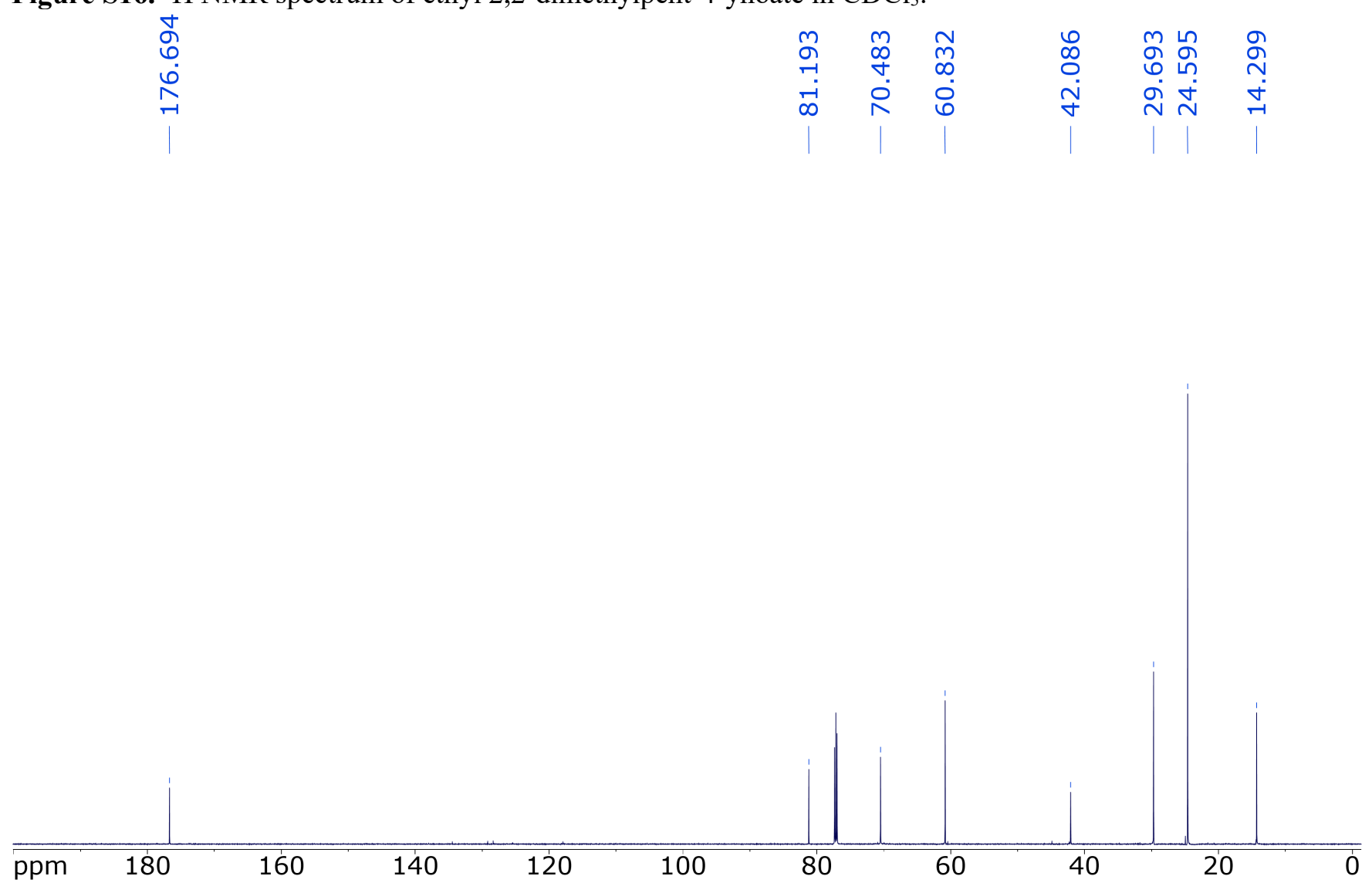

Figure S17. ${ }^{13} \mathrm{C}$ UDEFT NMR spectrum of ethyl 2,2-dimethylpent-4-ynoate in $\mathrm{CDCl}_{3}$. 


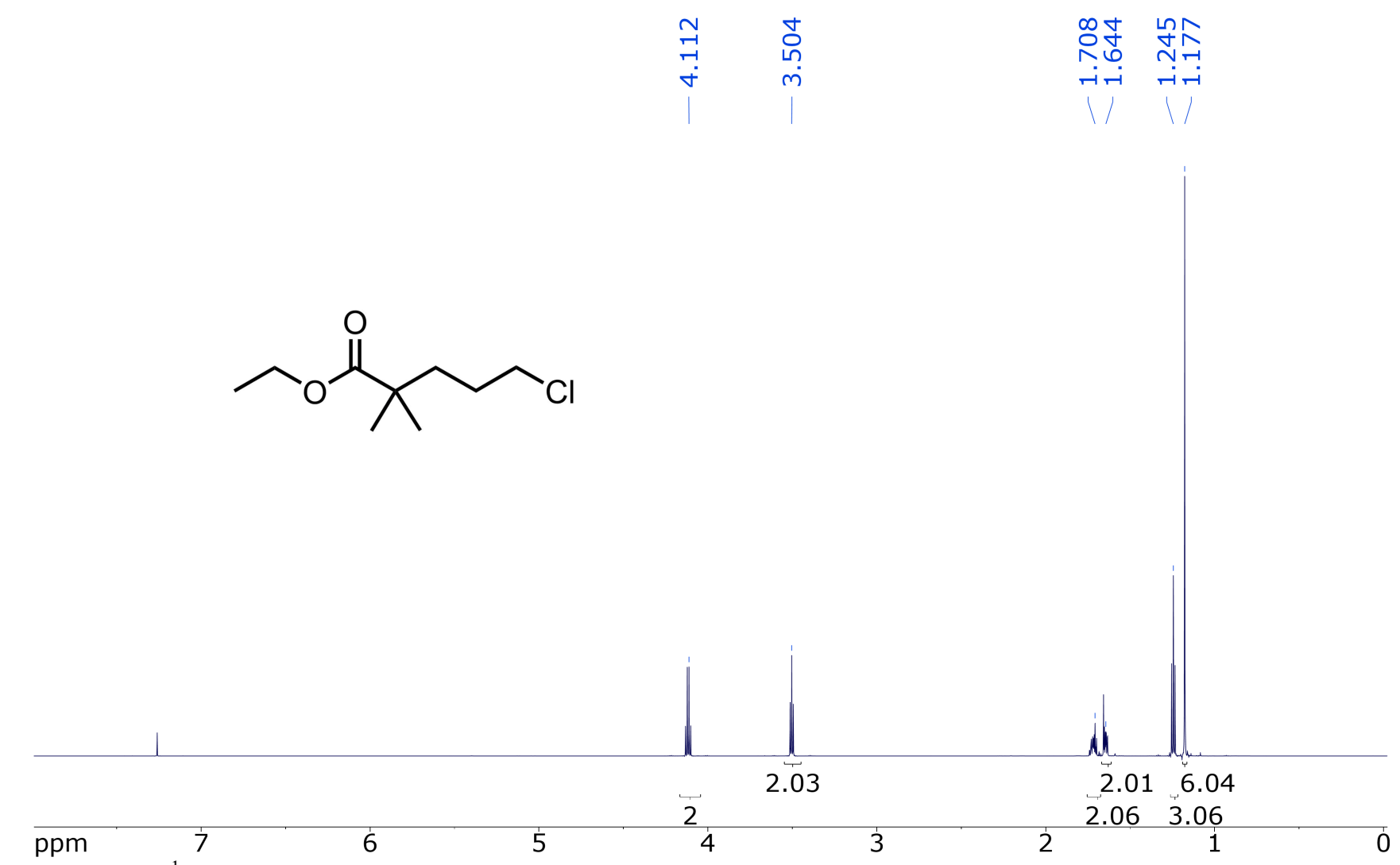

Figure S18. ${ }^{1} \mathrm{H}$ NMR of ethyl 5-chloro-2,2-dimethylpentanoate in $\mathrm{CDCl}_{3}$.

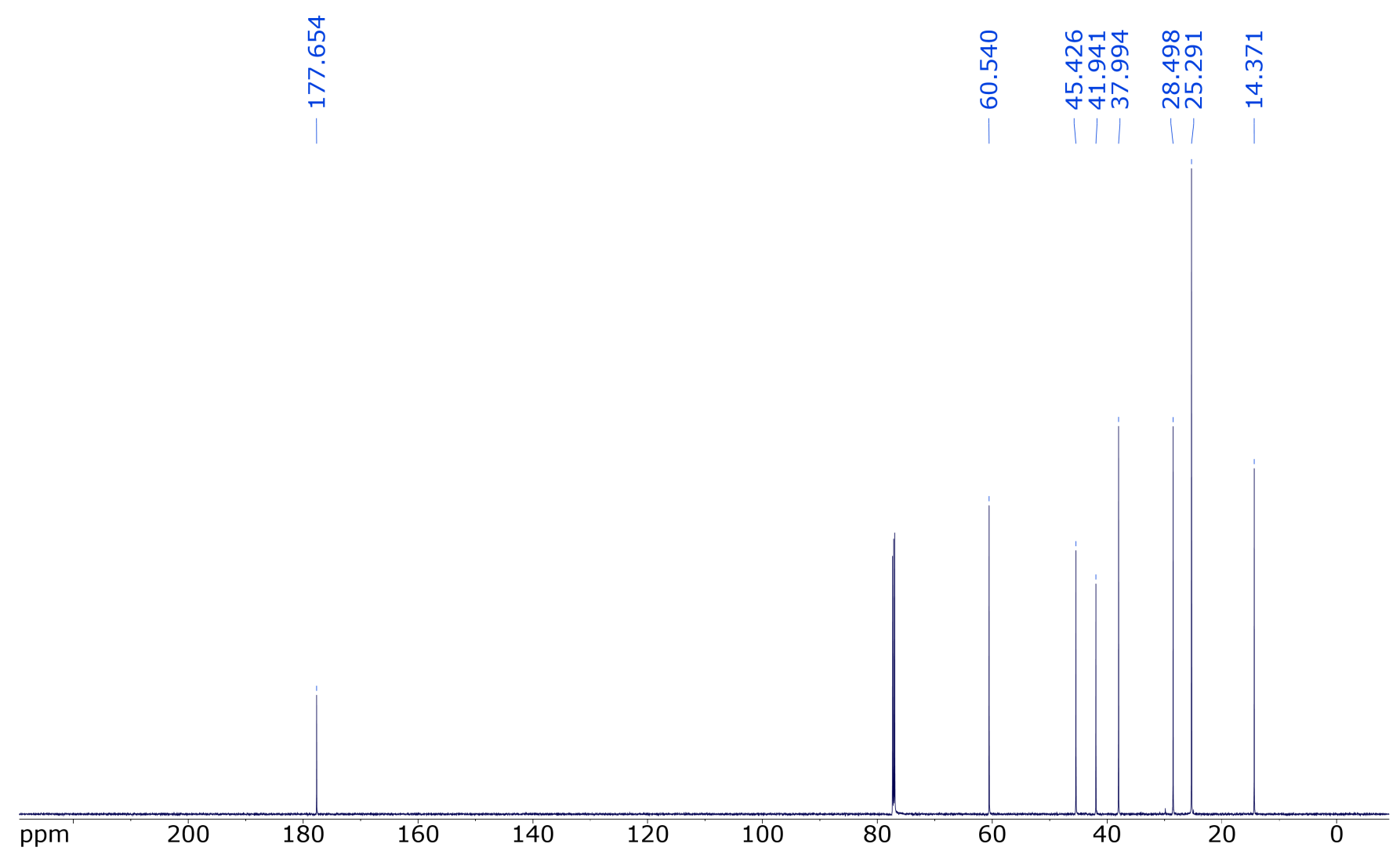

Figure S19. ${ }^{13} \mathrm{C}$ UDEFT NMR of ethyl 5-chloro-2,2-dimethylpentanoate in $\mathrm{CDCl}_{3}$. 


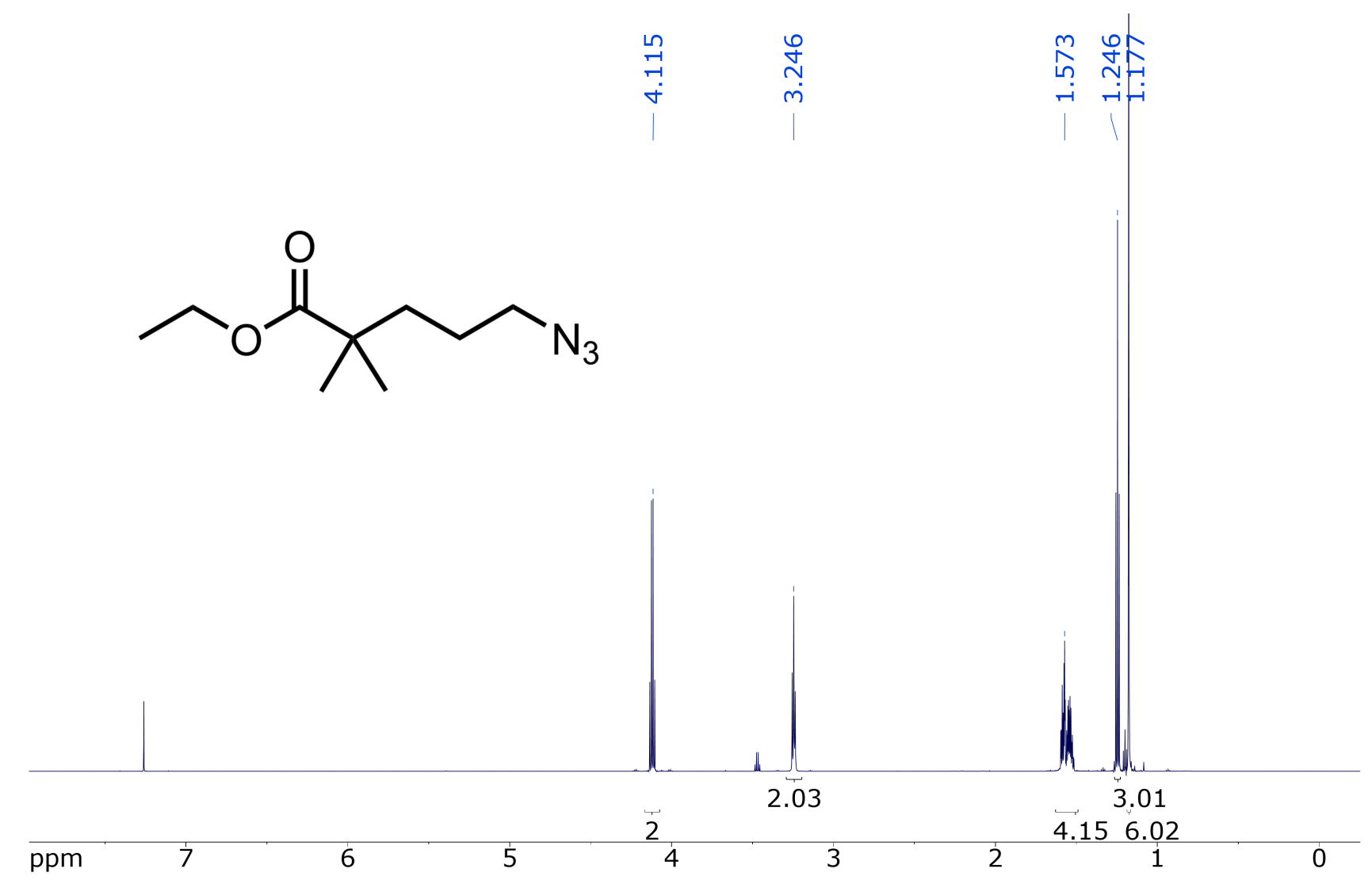

Figure S20. ${ }^{1} \mathrm{H}$ NMR of ethyl 5-azido-2,2-dimethylpentanoate in $\mathrm{CDCl}_{3}$.

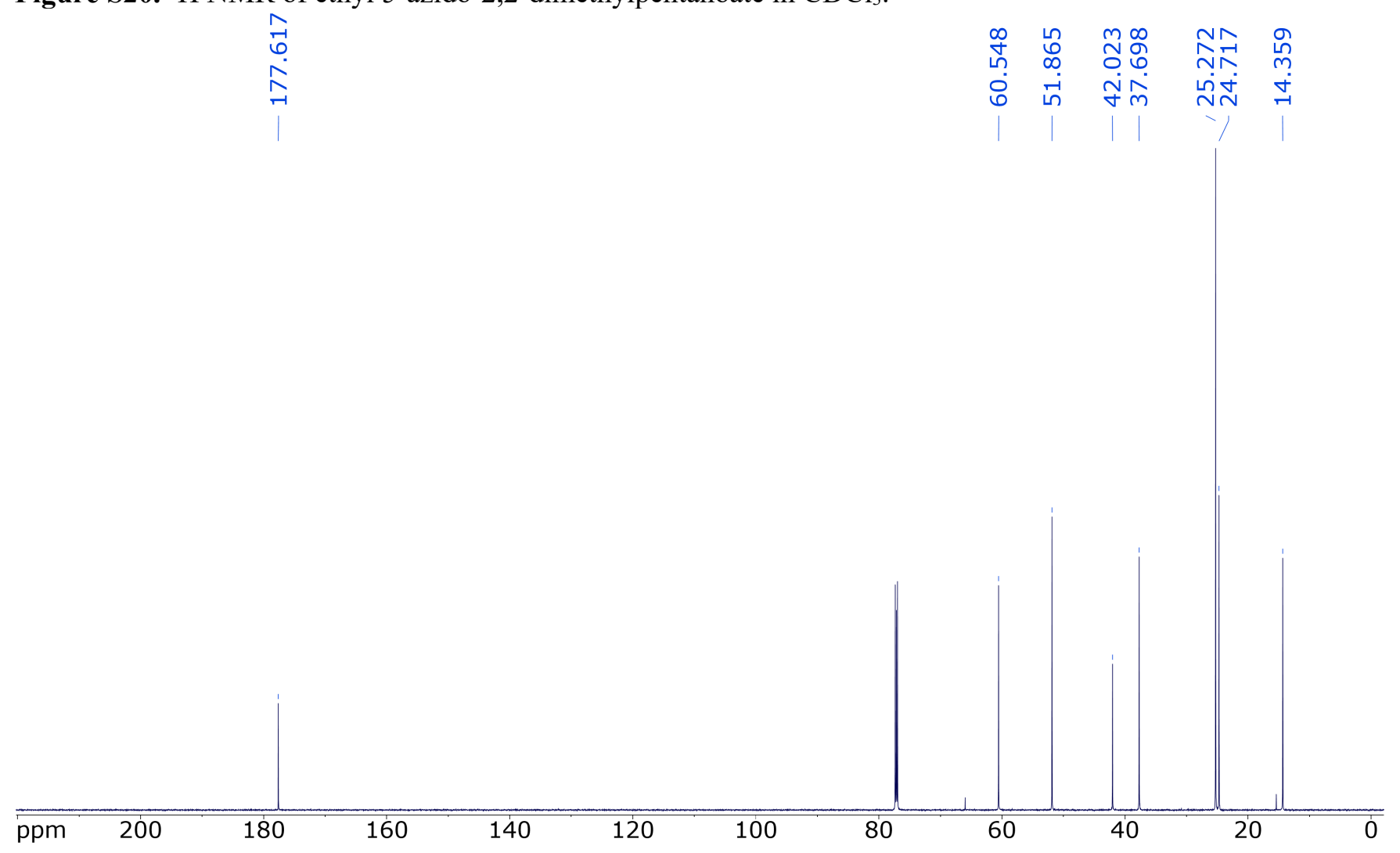

Figure S21. ${ }^{13} \mathrm{C}$ UDEFT NMR of ethyl 5-azido-2,2-dimethylpentanoate in $\mathrm{CDCl}_{3}$. 


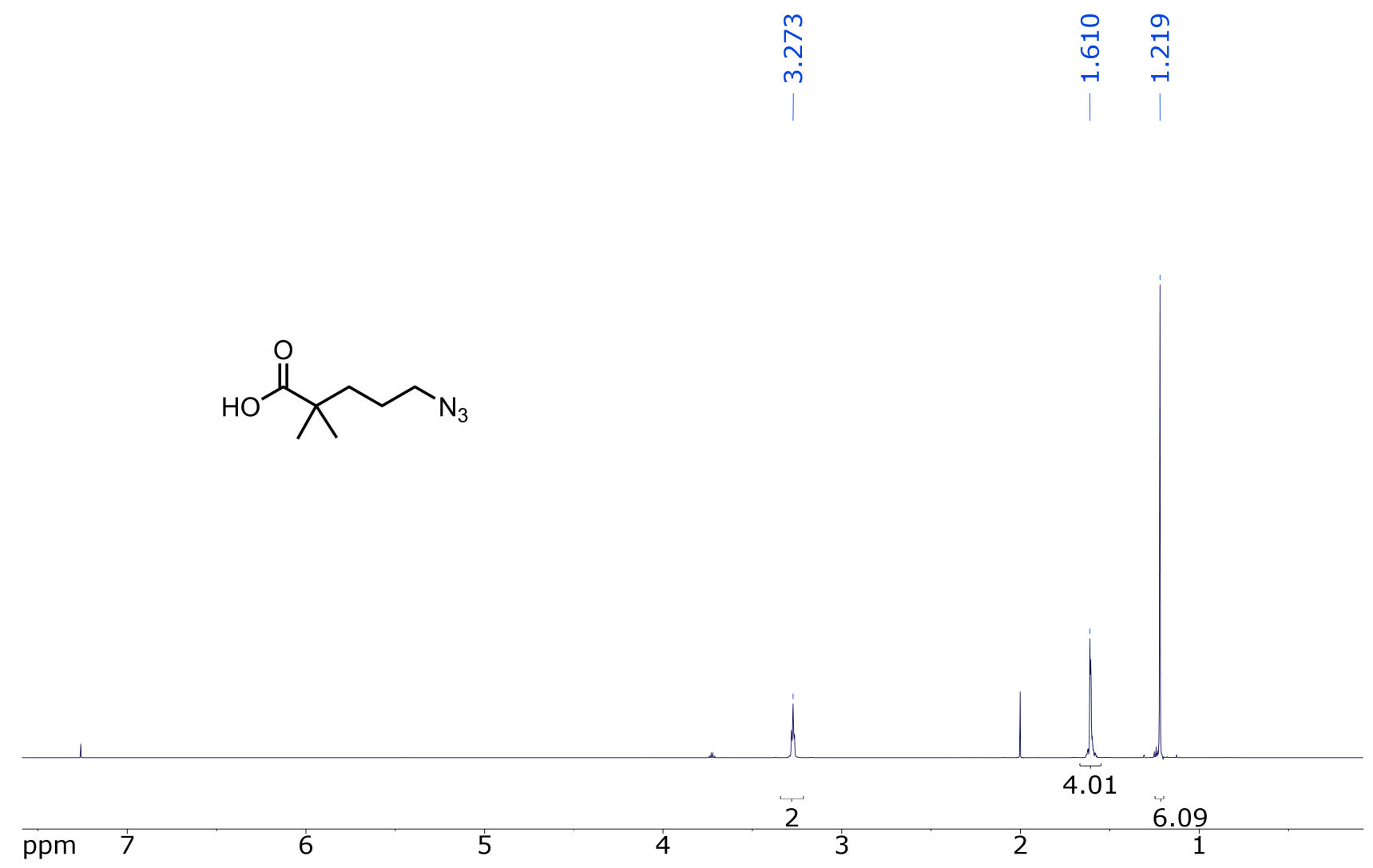

Figure S22. ${ }^{1} \mathrm{H}$ NMR of 5-azido-2,2-dimethylpentanoic acid in $\mathrm{CDCl}_{3}$.

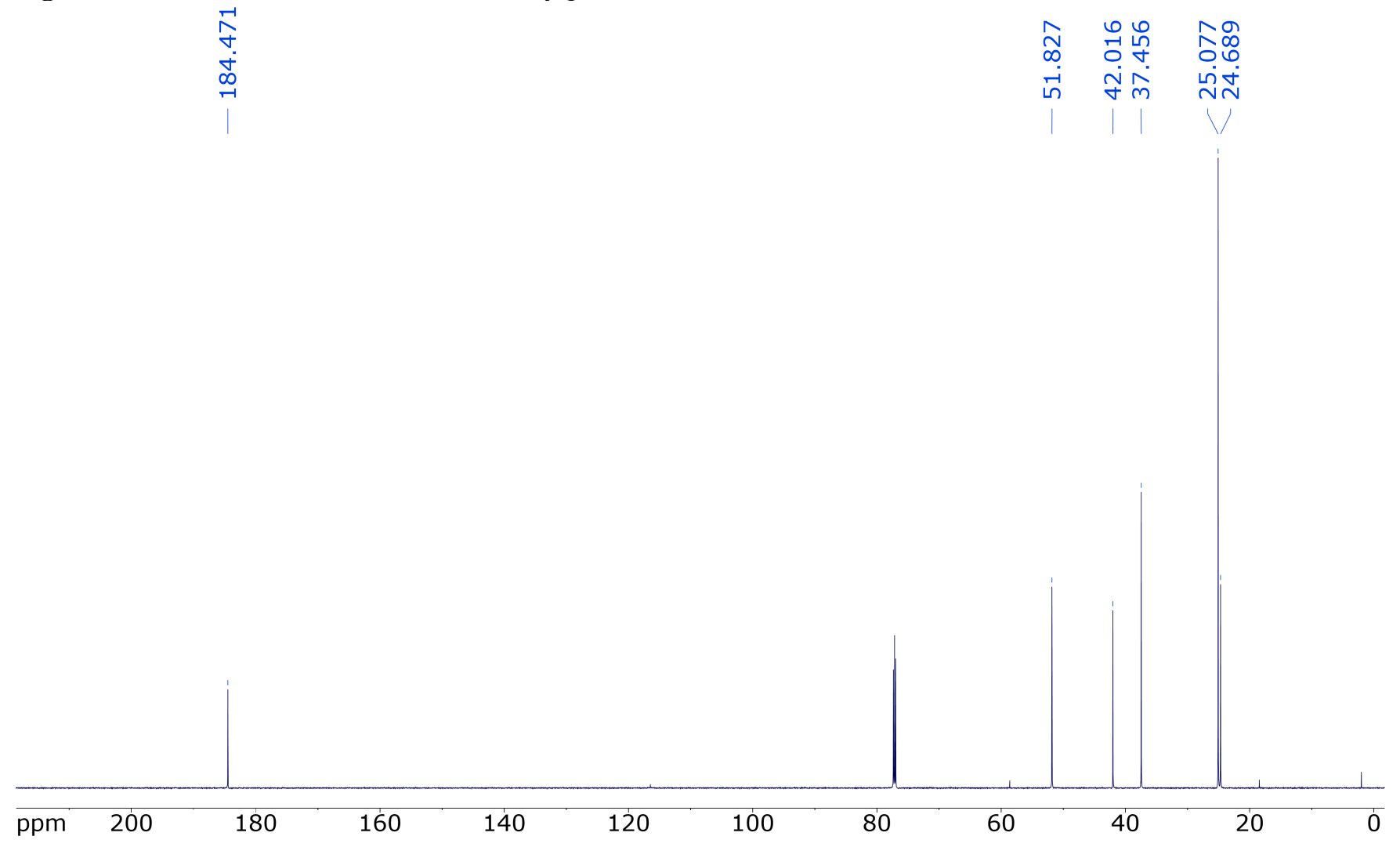

Figure S23. ${ }^{13} \mathrm{C}$ UDEFT NMR of 5-azido-2,2-dimethylpentanoic acid in $\mathrm{CDCl}_{3}$. 


\section{Dendron NMR Data}
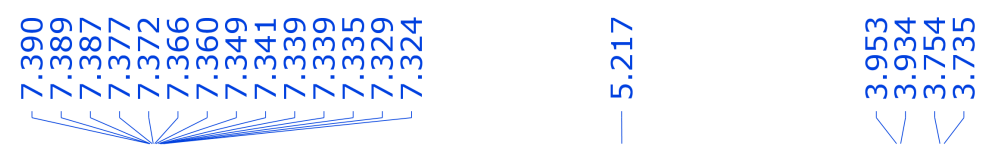

$\begin{array}{ll}\hat{n} & m \\ & 0 \\ i & +i\end{array}$
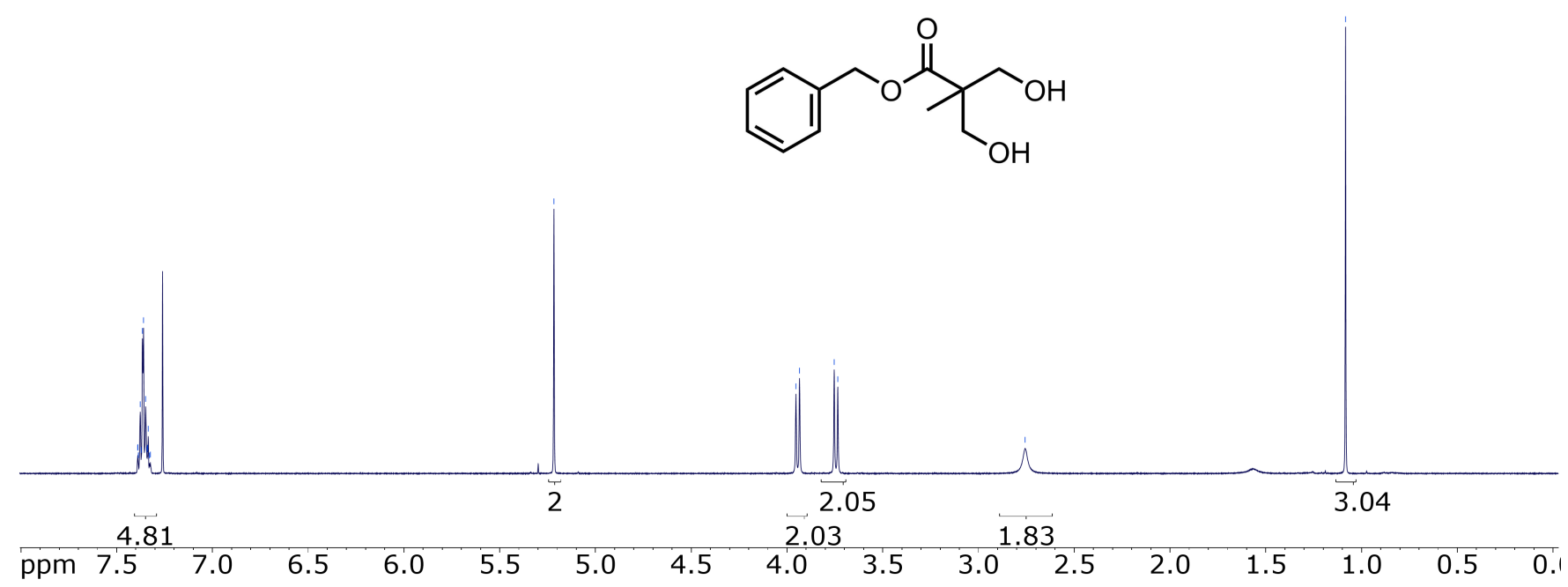

Figure S24. ${ }^{1} \mathrm{H}$ NMR of BnO-G1-(OH $)_{2}$ in $\mathrm{CDCl}_{3}$.

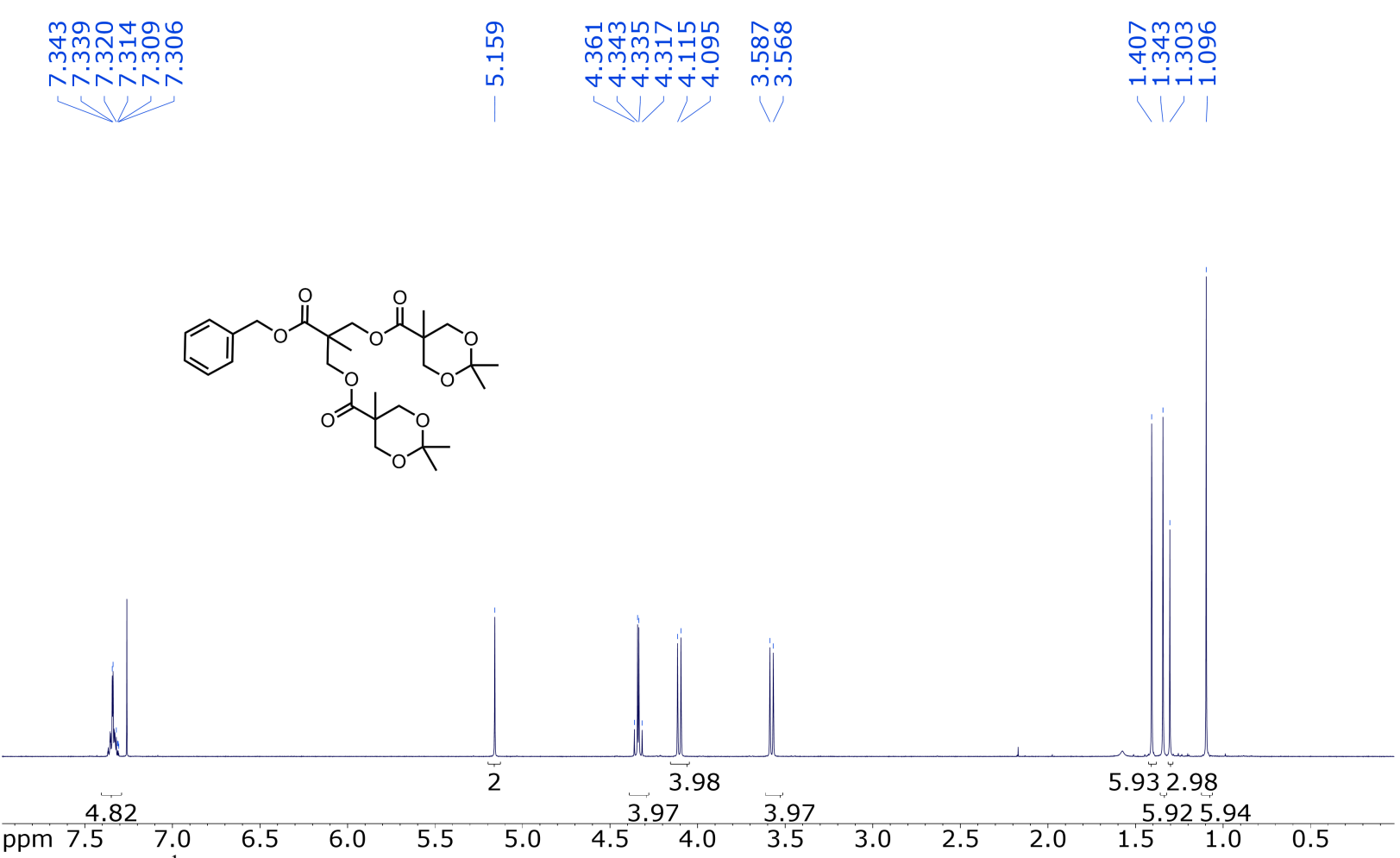

Figure S25. ${ }^{1} \mathrm{H}$ NMR of BnO-G2-(acet) $)_{2}$ in $\mathrm{CDCl}_{3}$. 


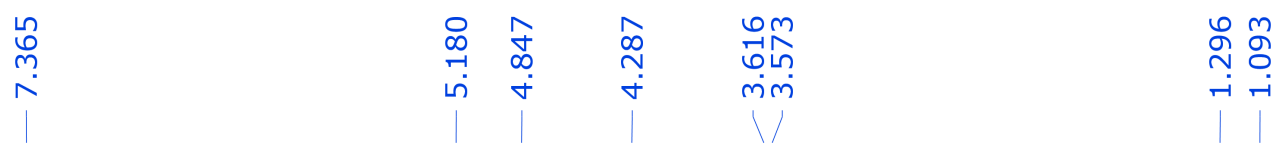<smiles>O=C(OCC(COCc1ccccc1)(COC(=O)C(CO)(CO)CO)C(=O)OCc1ccccc1)C(CO)(CO)CO</smiles>

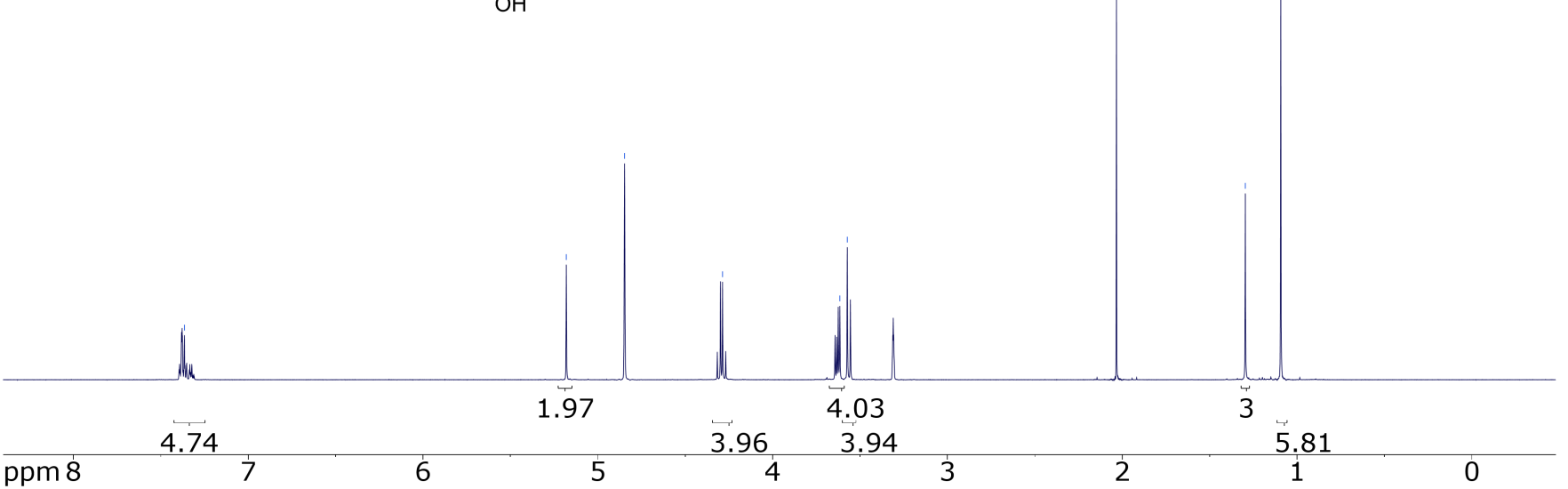

Figure S26. ${ }^{1} \mathrm{H}$ NMR of BnO-G2-(OH $)_{4}$ in $\mathrm{MeOD}$. 


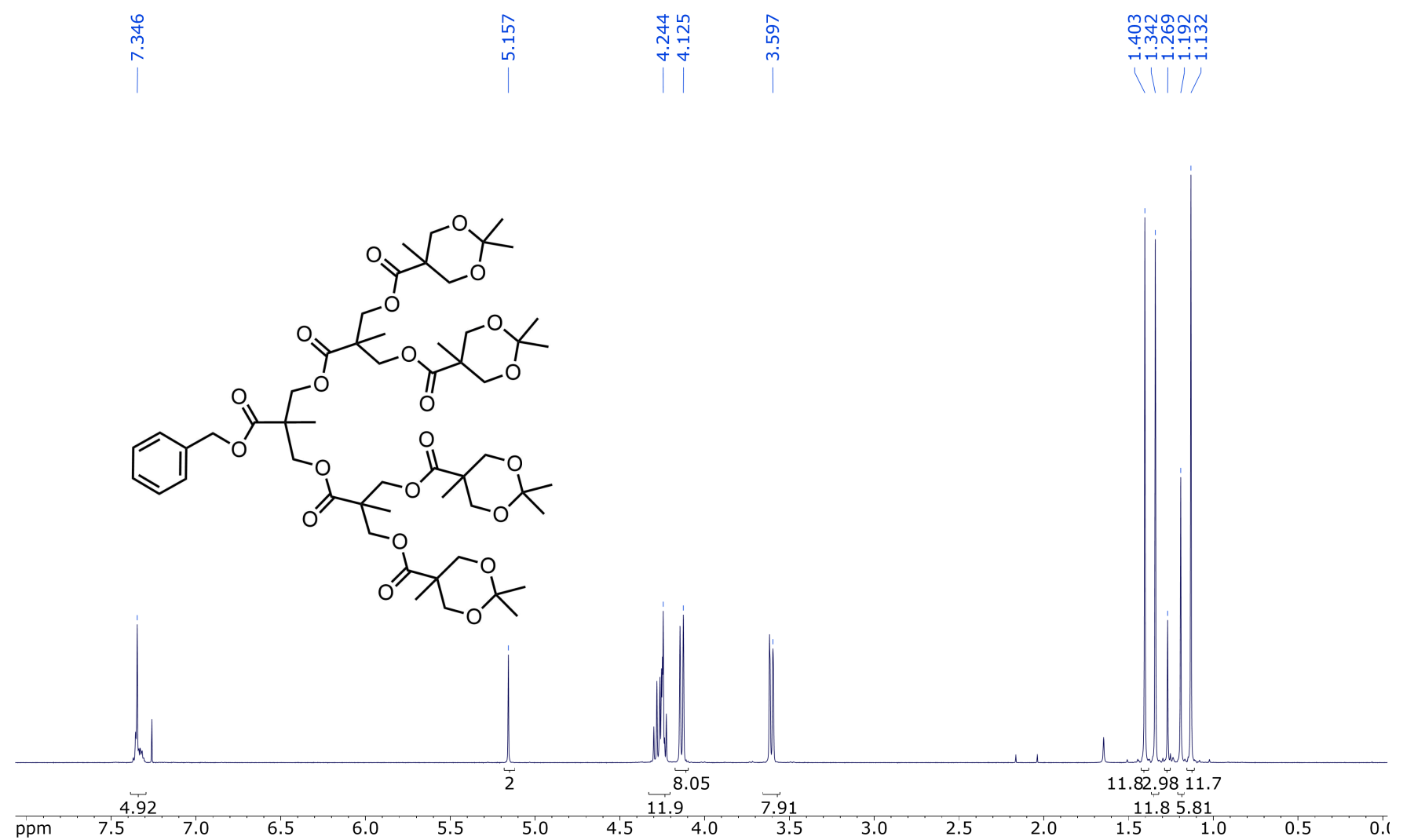

Figure S27. ${ }^{1} \mathrm{H}$ NMR of BnO-G3-(acet) $)_{4}$ in $\mathrm{CDCl}_{3}$.

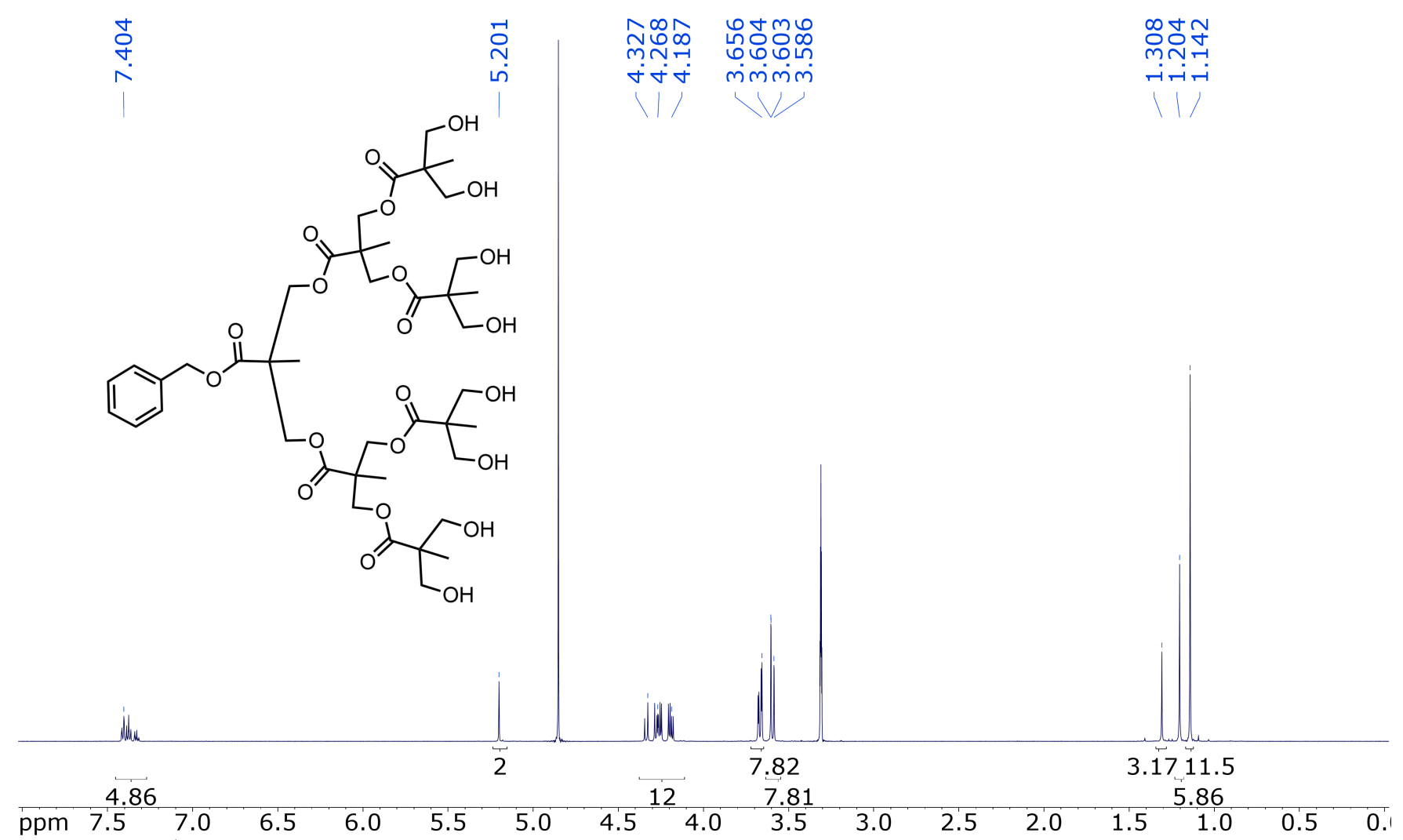

Figure S28. ${ }^{1} \mathrm{H}$ NMR of BnO-G3-(OH $)_{8}$ in MeOD. 


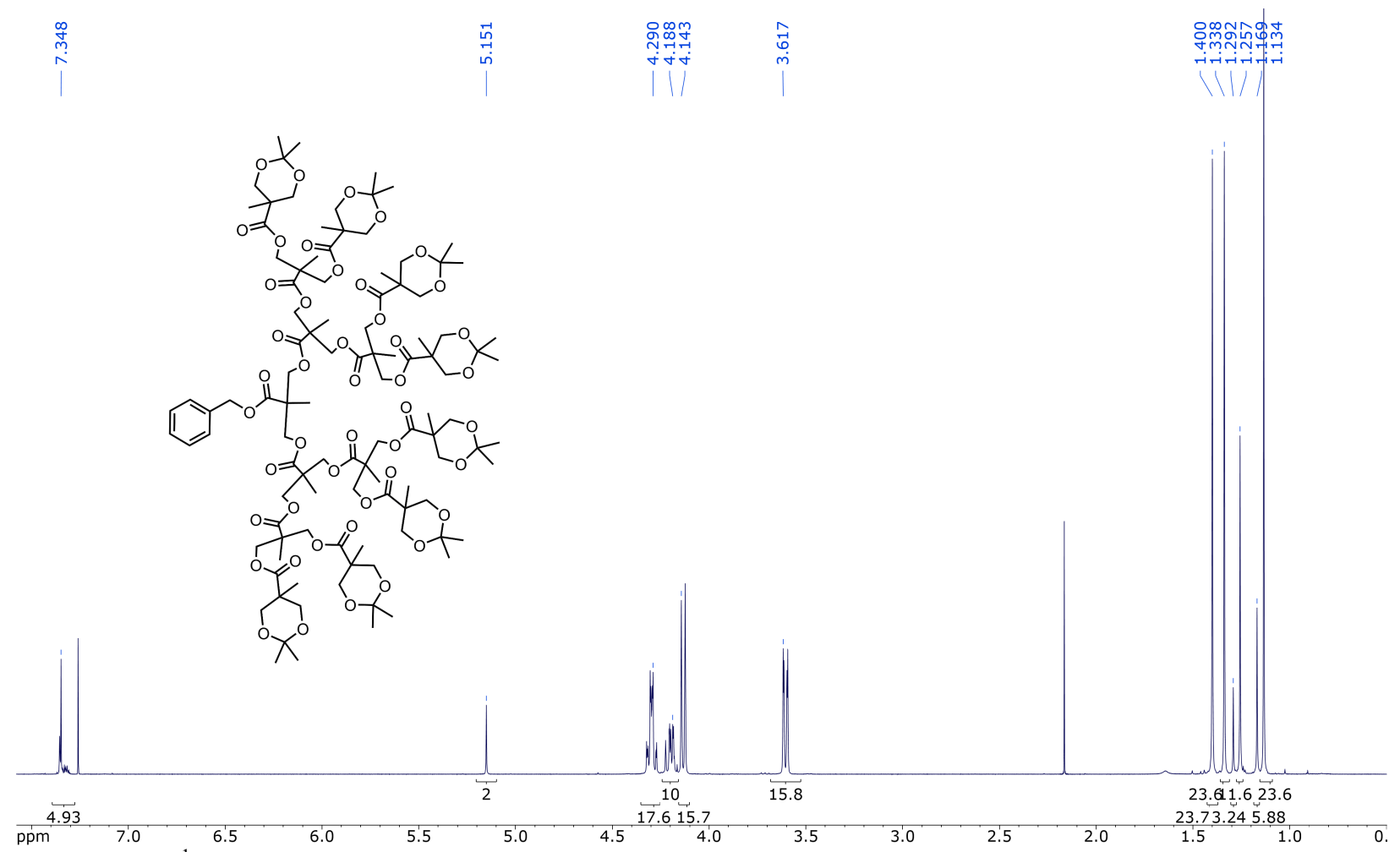

Figure S29. ${ }^{1} \mathrm{H}$ NMR of BnO-G4-(acet) 8 in $\mathrm{CDCl}_{3}$.

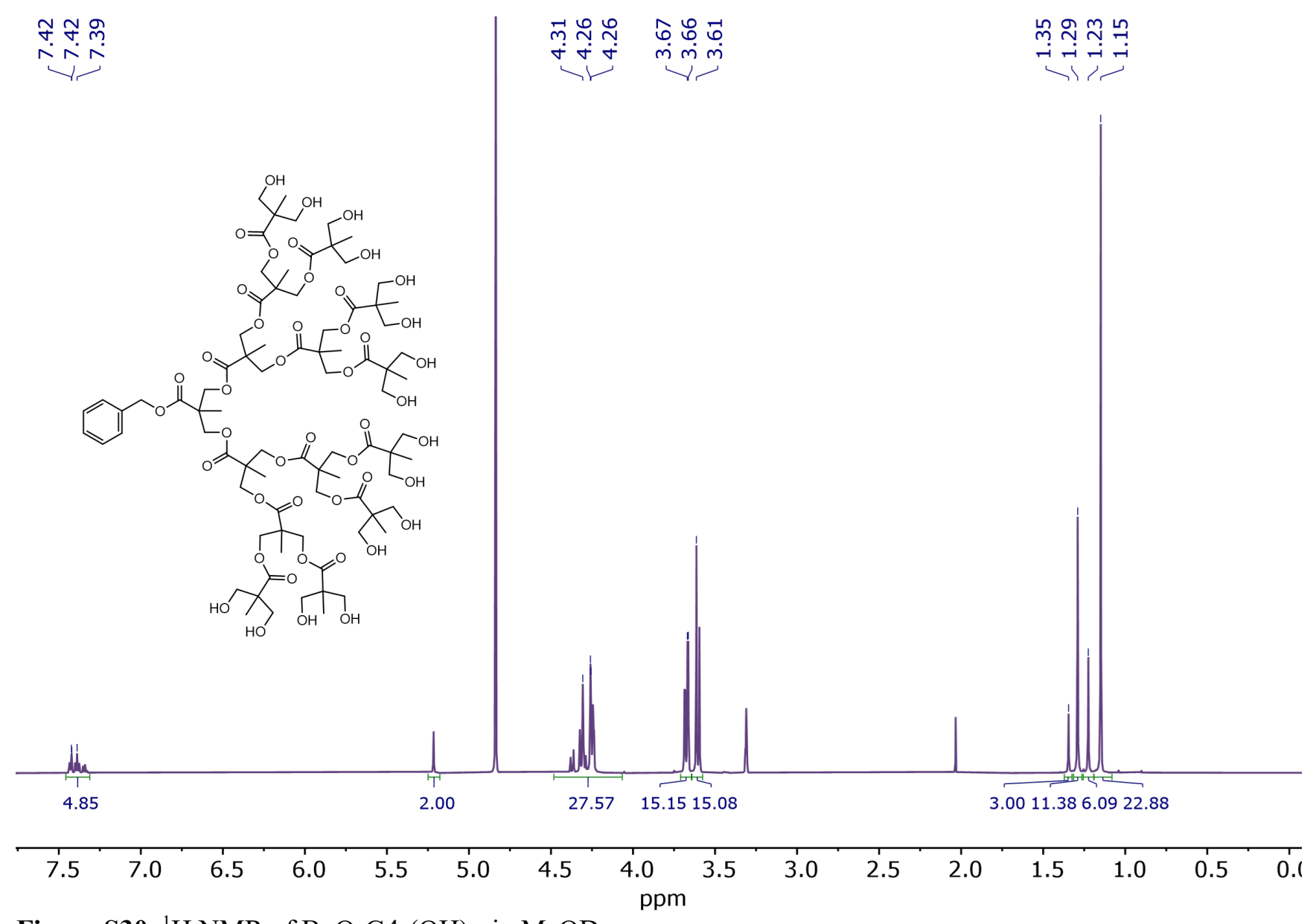

Figure S30. ${ }^{1} \mathrm{H}$ NMR of BnO-G4-(OH) ${ }_{16}$ in MeOD. 


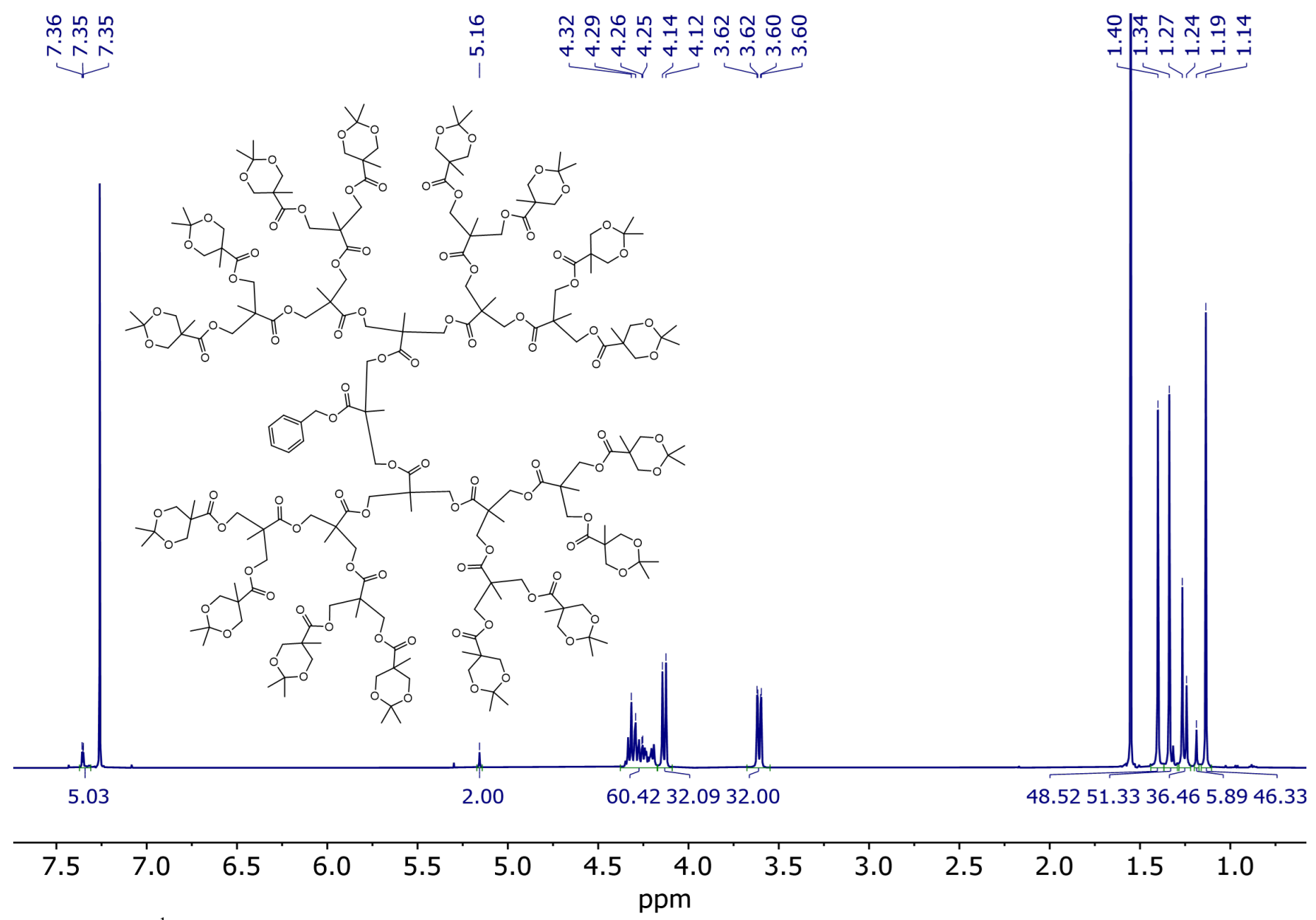

Figure S31. ${ }^{1} \mathrm{H}$ NMR of BnO-G5-(acet) ${ }_{16}$ in $\mathrm{CDCl}_{3}$. 


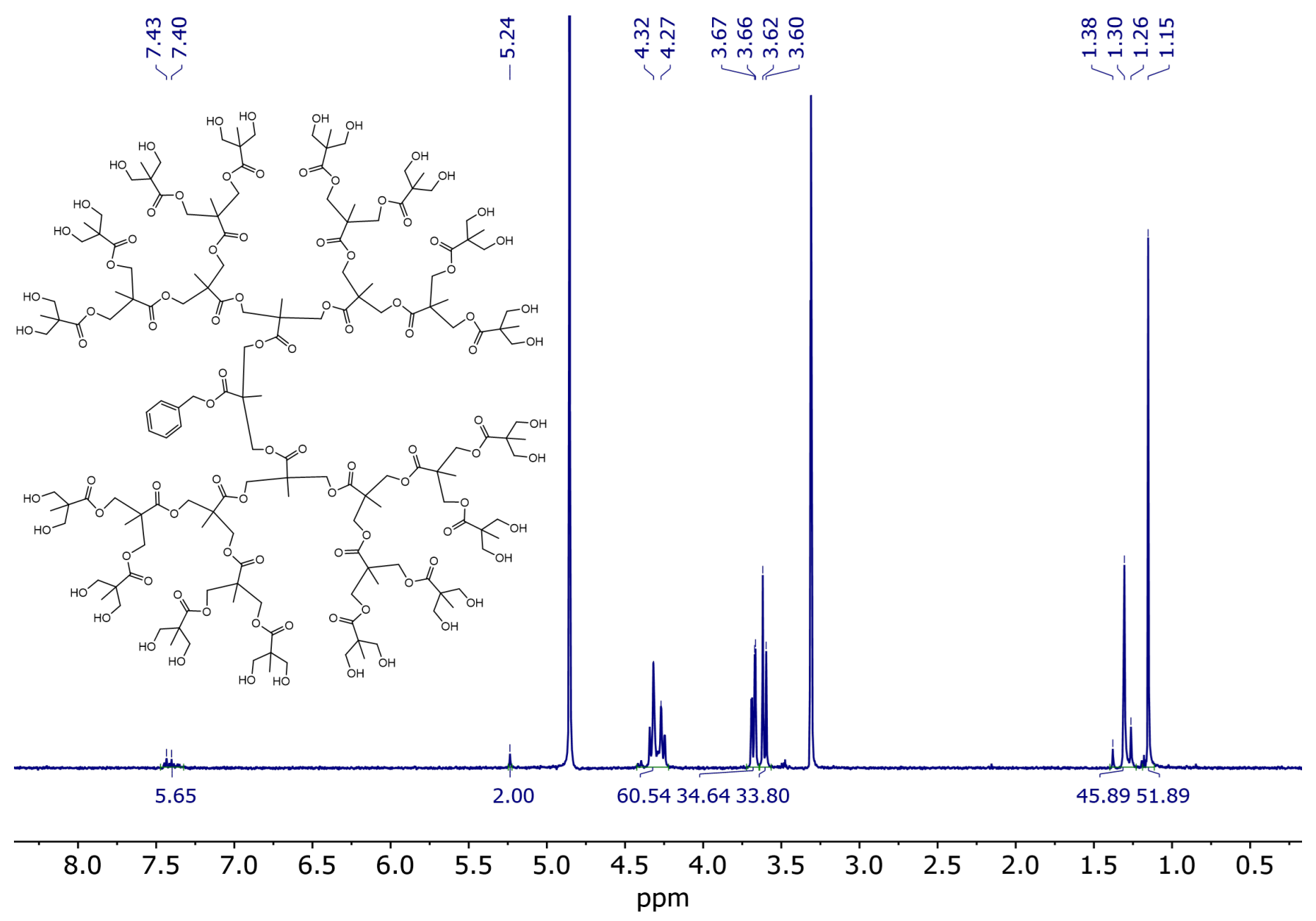

Figure S32. ${ }^{1} \mathrm{H}$ NMR of BnO-G5-(OH $)_{32}$ in $\mathrm{MeOD}$. 

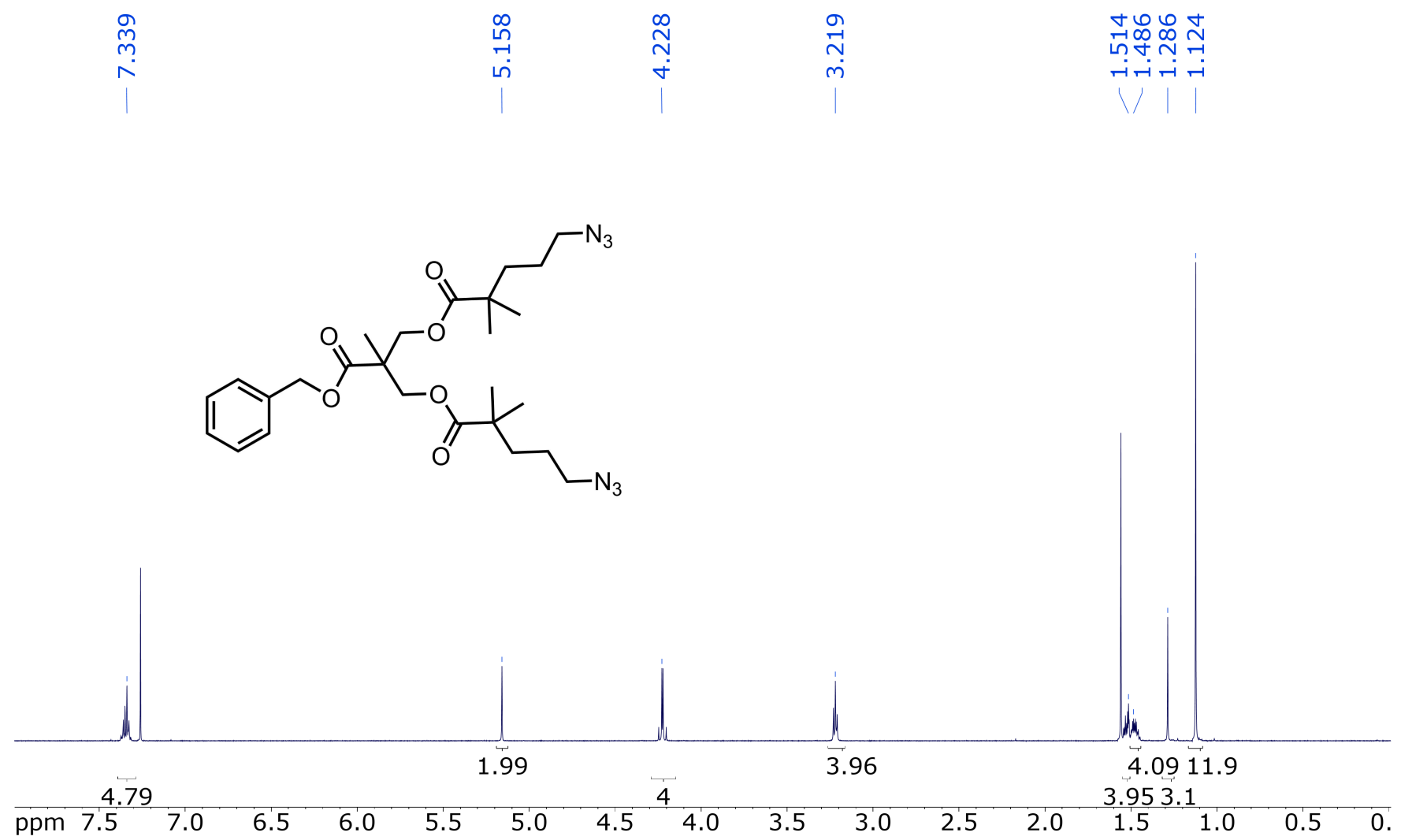

(1)

îं

Figure S33. ${ }^{1} \mathrm{H}$ NMR of $\mathrm{BnO}-\mathrm{G} 1-\left(\mathrm{N}_{3}\right)_{2}$ in $\mathrm{CDCl}_{3}$.
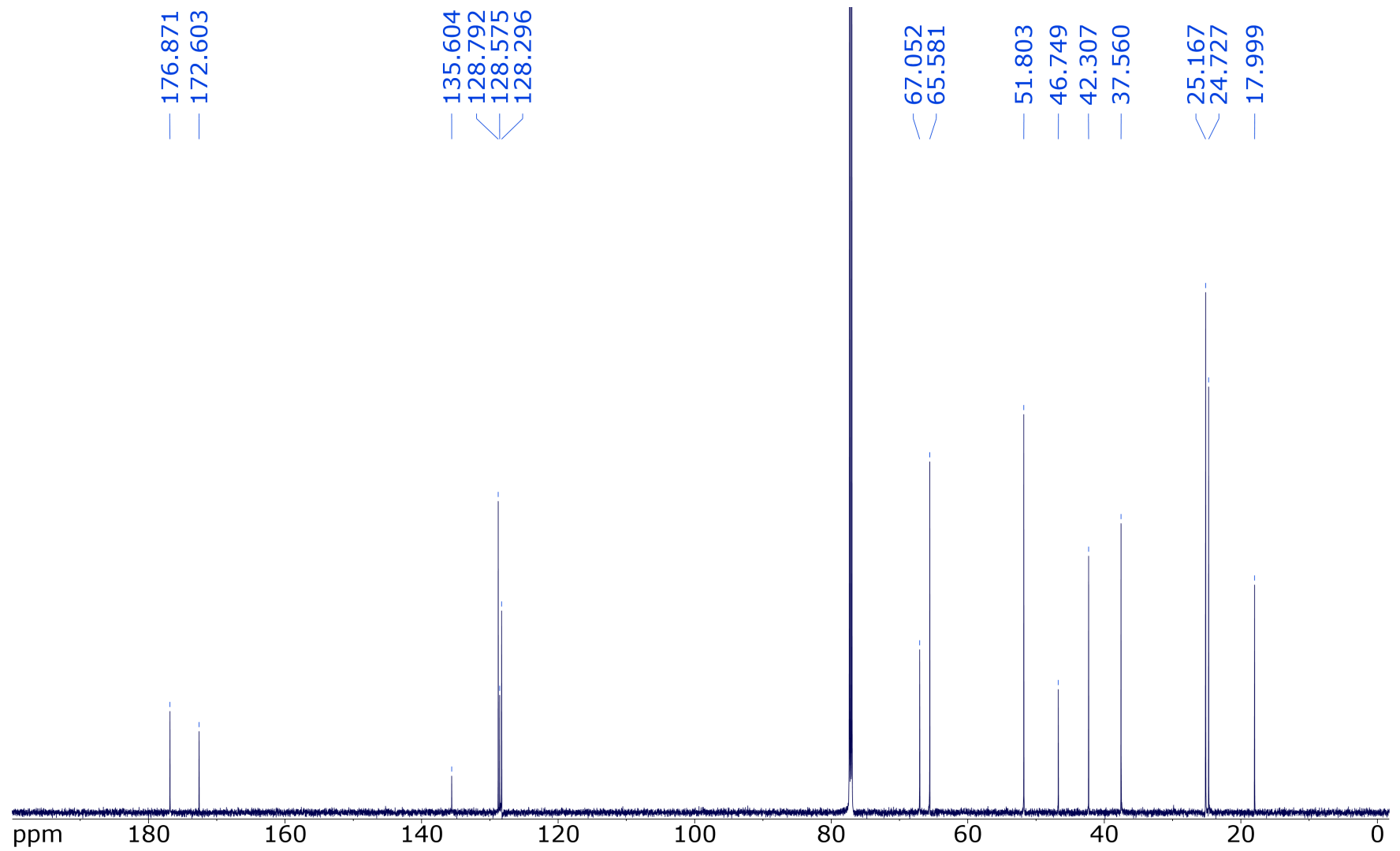

Figure S34. ${ }^{13} \mathrm{C}$ NMR of BnO-G1- $\left(\mathrm{N}_{3}\right)_{2}$ in $\mathrm{CDCl}_{3}$. 


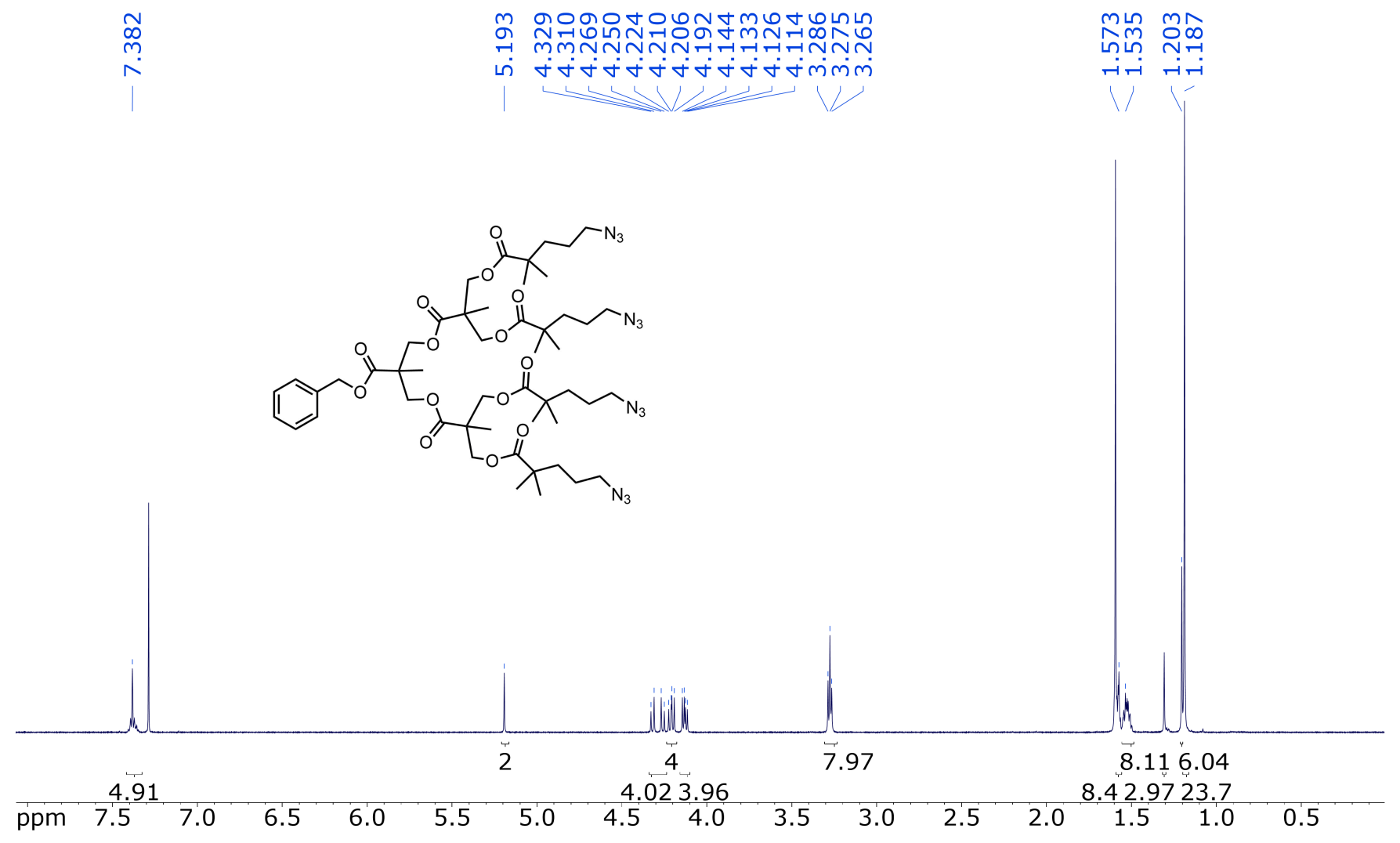

Figure S35. ${ }^{1} \mathrm{H}$ NMR of BnO-G2-( $\left.\mathrm{N}_{3}\right)_{4}$ in $\mathrm{CDCl}_{3}$.

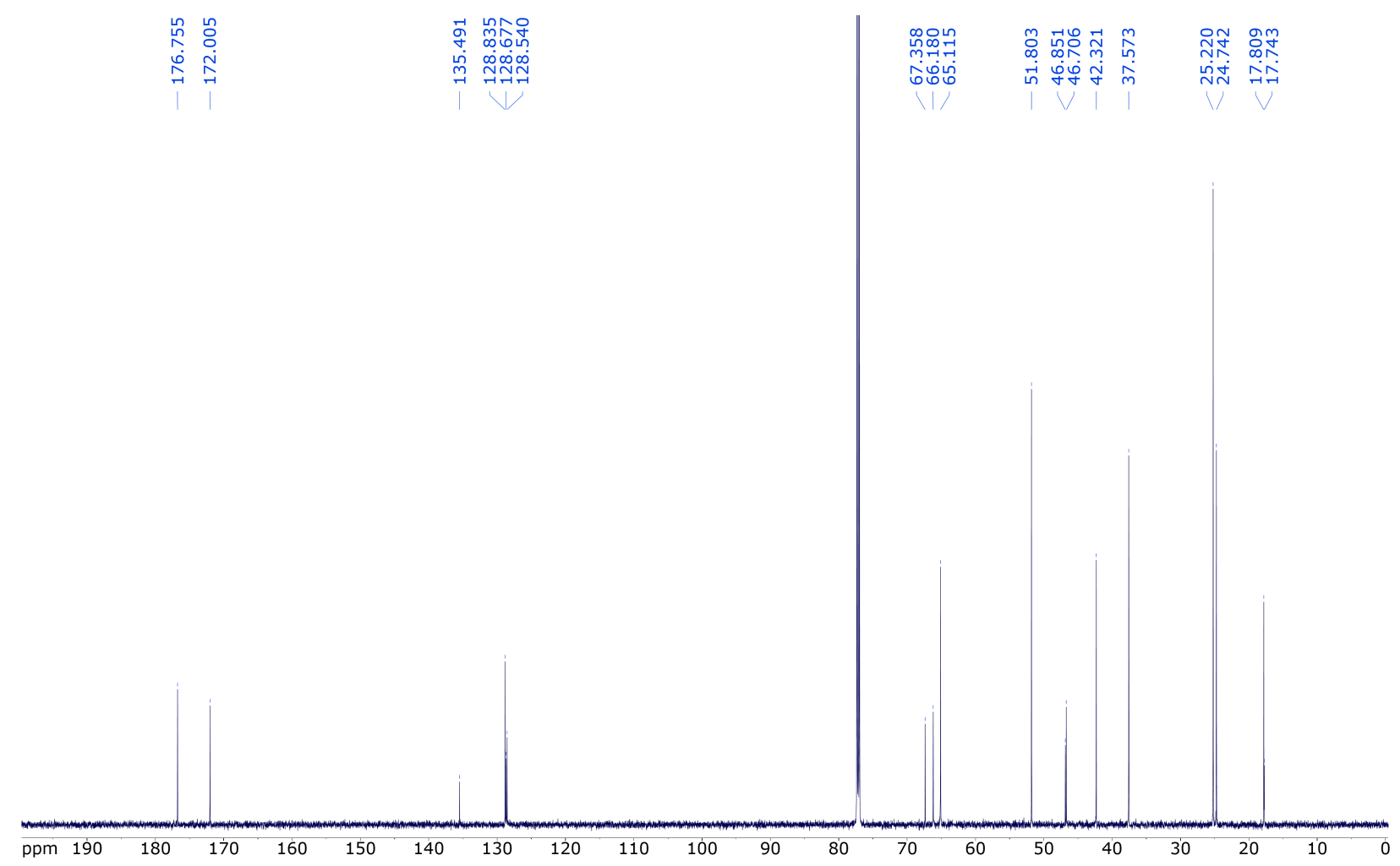

Figure S36. ${ }^{13} \mathrm{C}$ NMR of BnO-G2-( $\left.\mathrm{N}_{3}\right)_{4}$ in $\mathrm{CDCl}_{3}$. 


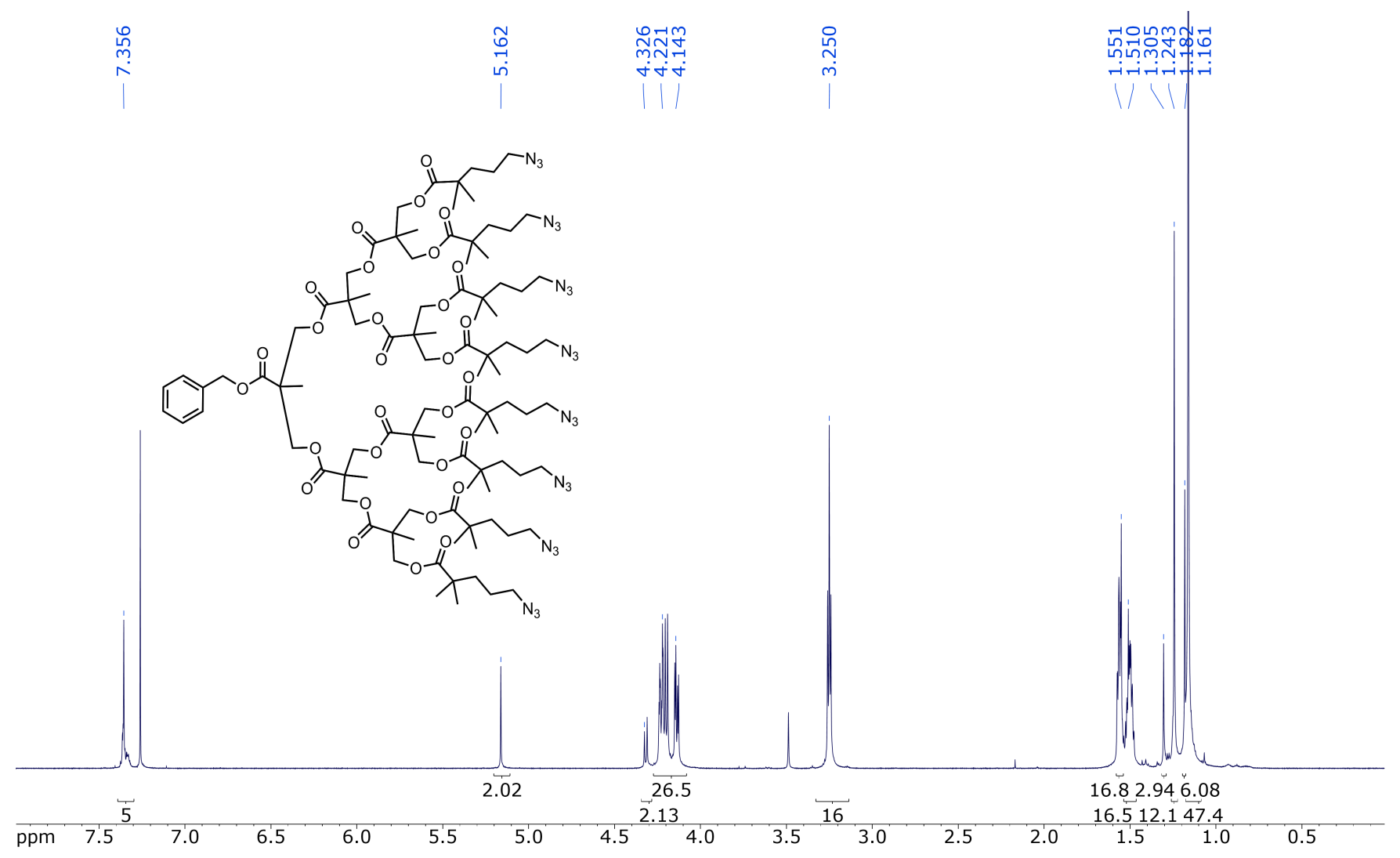

Figure S37. ${ }^{1} \mathrm{H}$ NMR of $\mathrm{BnO}-\mathrm{G} 3-\left(\mathrm{N}_{3}\right)_{8}$ in $\mathrm{CDCl}_{3}$.

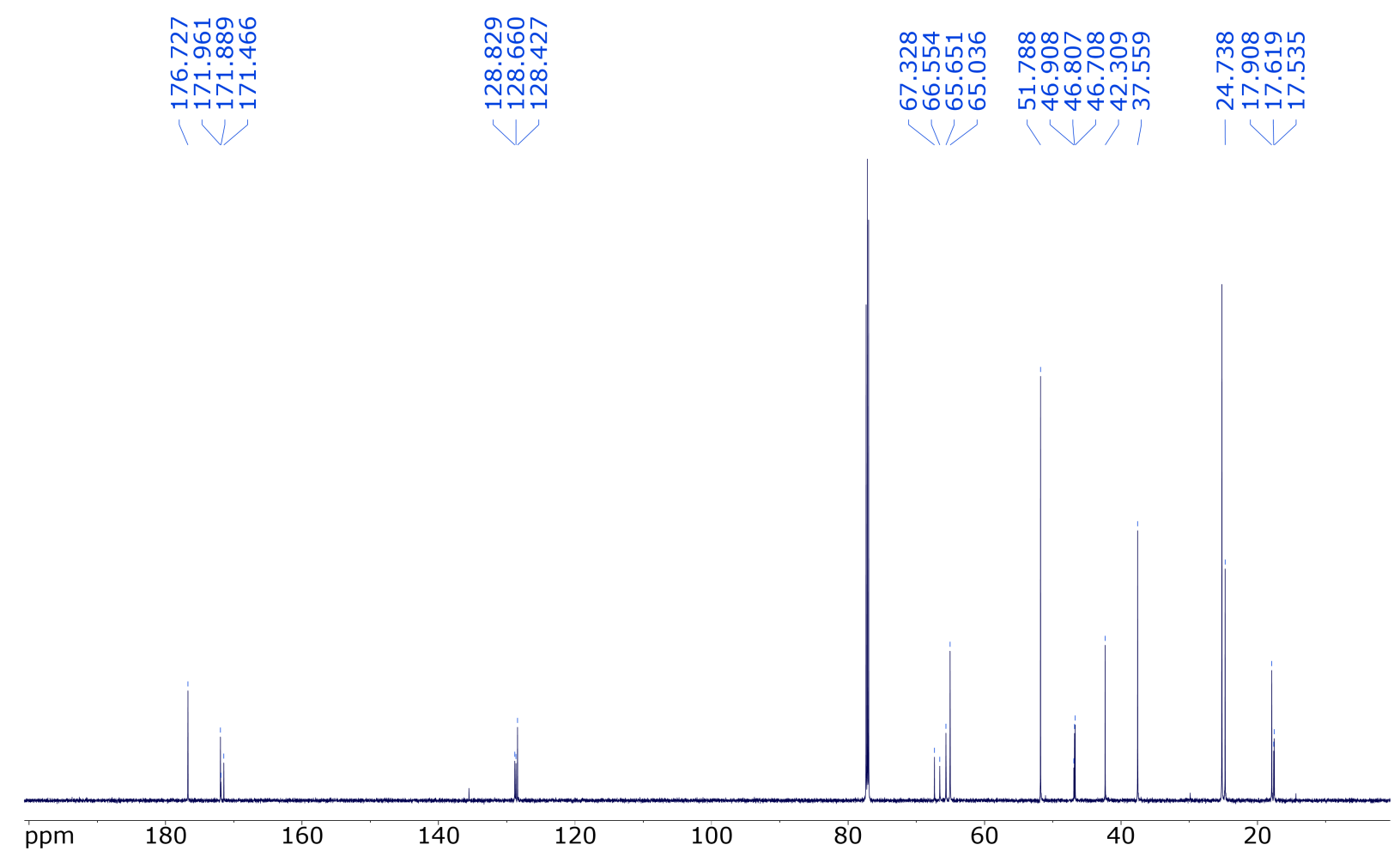

Figure S38. ${ }^{13} \mathrm{C}$ NMR of BnO-G3- $\left(\mathrm{N}_{3}\right)_{8}$ in $\mathrm{CDCl}_{3}$. 


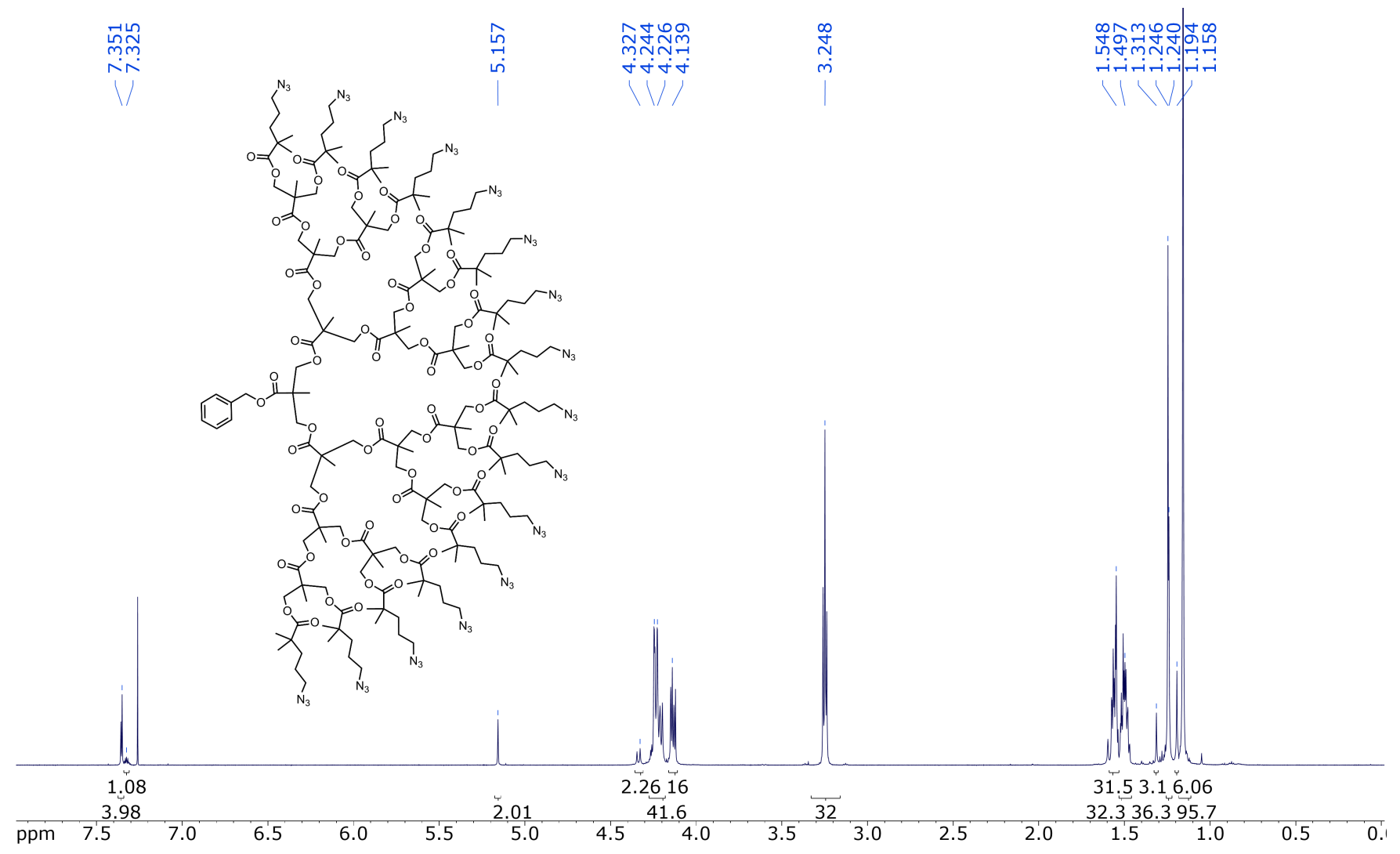

Figure S39. ${ }^{1} \mathrm{H}$ NMR of BnO-G4-( $\left.\mathrm{N}_{3}\right)_{16}$ in $\mathrm{CDCl}_{3}$.

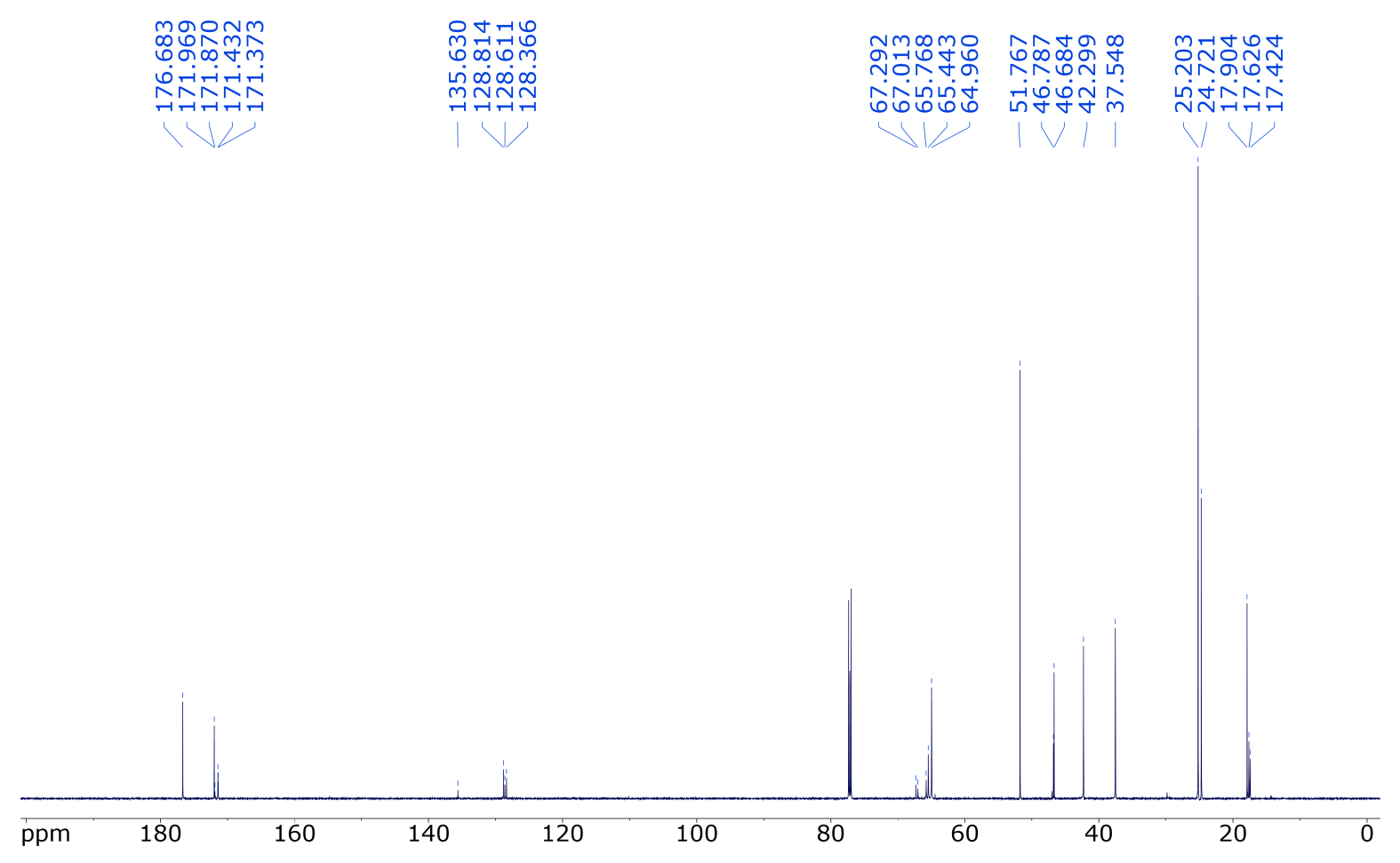

Figure S40. ${ }^{13} \mathrm{C}$ NMR of BnO-G4- $\left(\mathrm{N}_{3}\right)_{16}$ in $\mathrm{CDCl}_{3}$. 


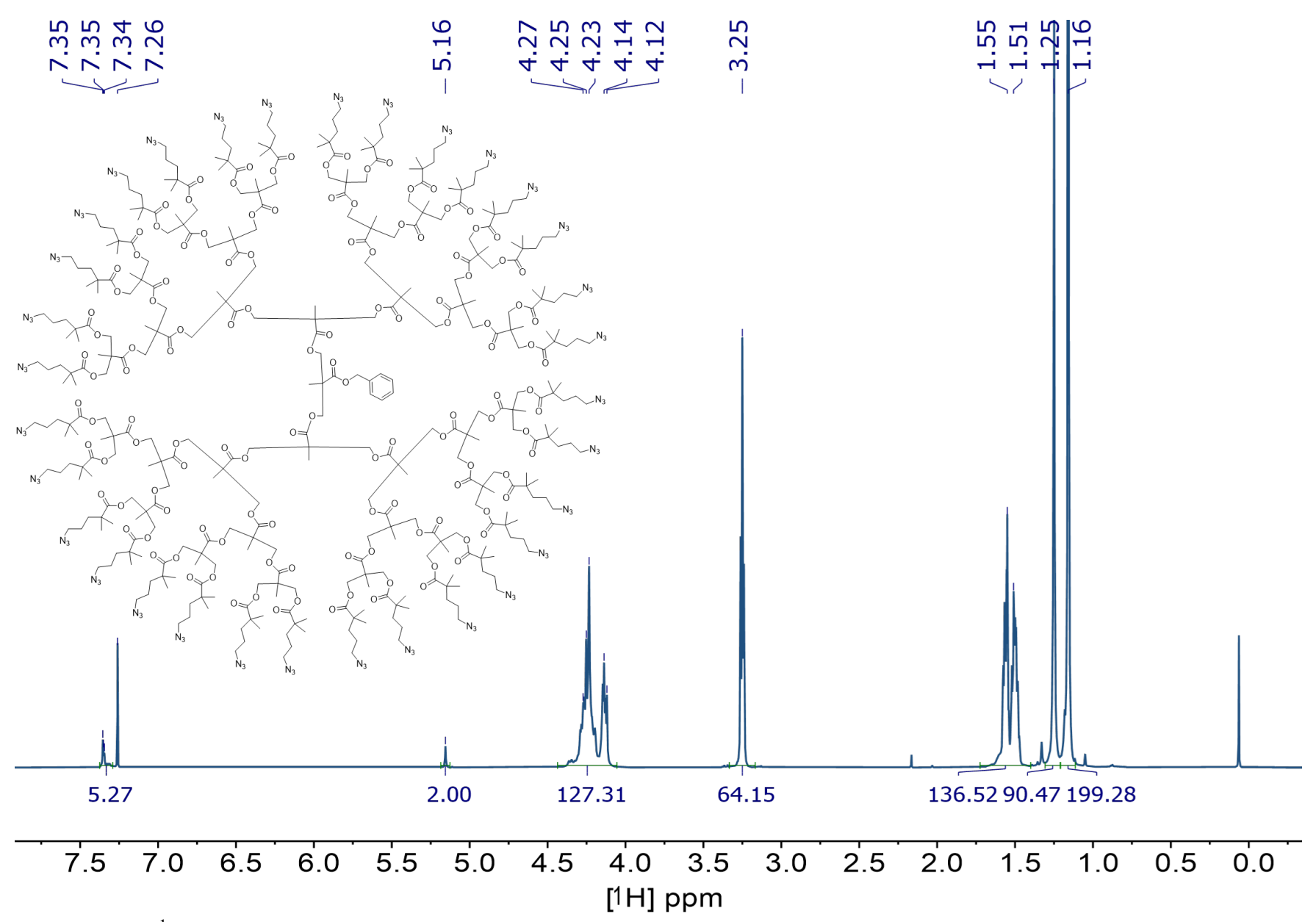

Figure S41. ${ }^{1} \mathrm{H}$ NMR of BnO-G5-( $\left.\mathrm{N}_{3}\right)_{32}$ in $\mathrm{CDCl}_{3}$.

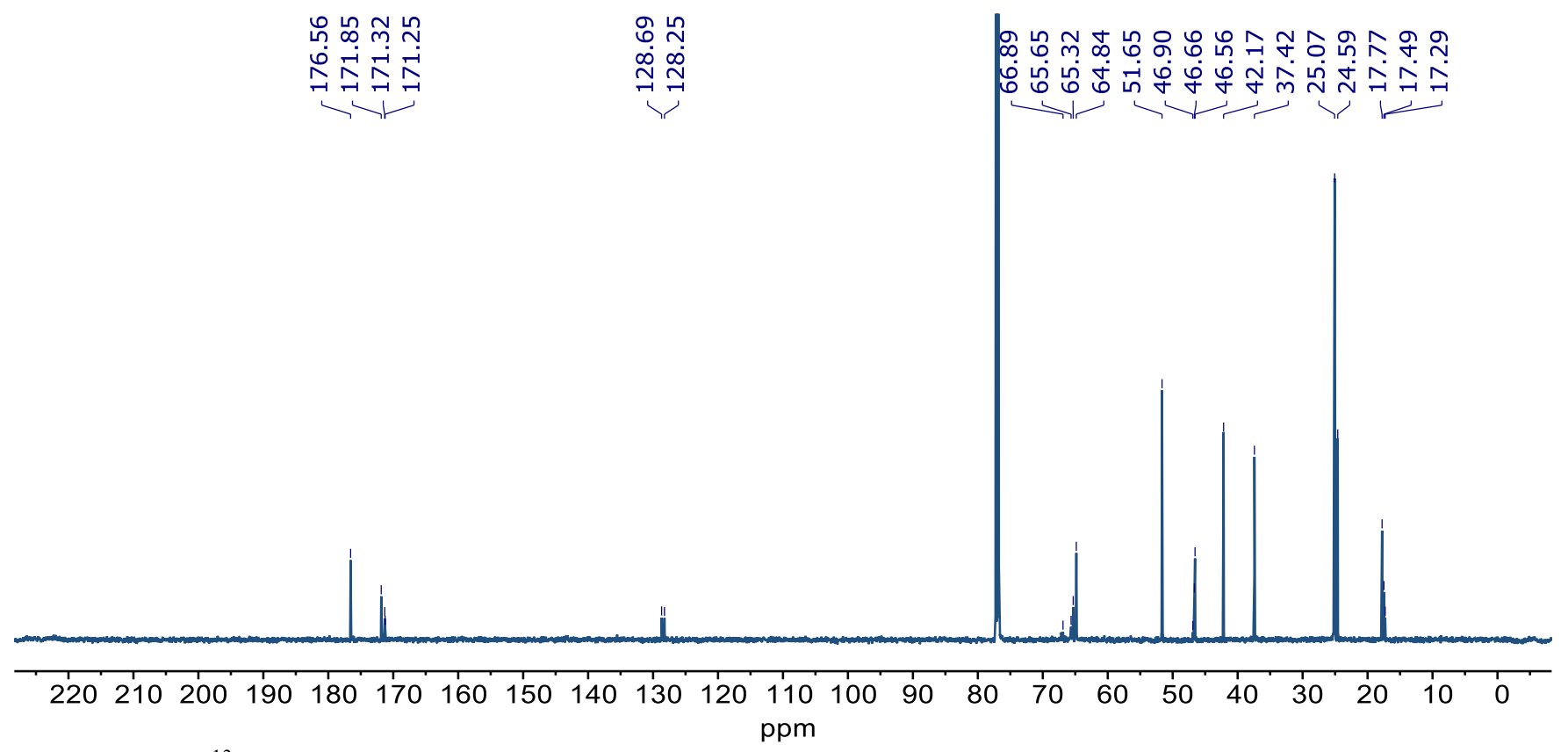

Figure S42. ${ }^{13} \mathrm{C}$ NMR of BnO-G5- $\left(\mathrm{N}_{3}\right)_{32}$ in $\mathrm{CDCl}_{3}$. 


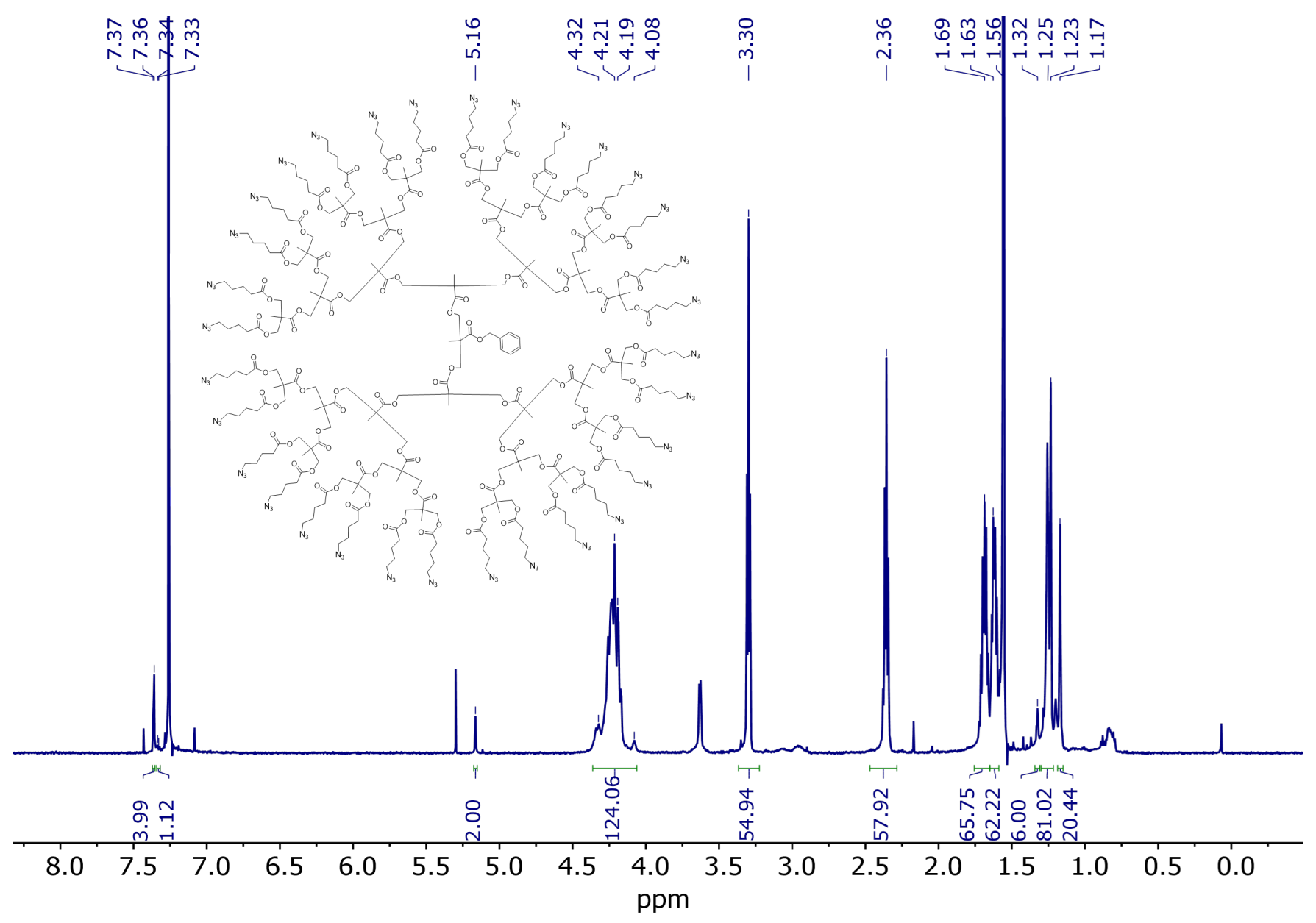

Figure S43. ${ }^{1} \mathrm{H}$ NMR of BnO-G5-Lin- $\mathrm{N}_{3}$ in $\mathrm{CDCl}_{3}$.

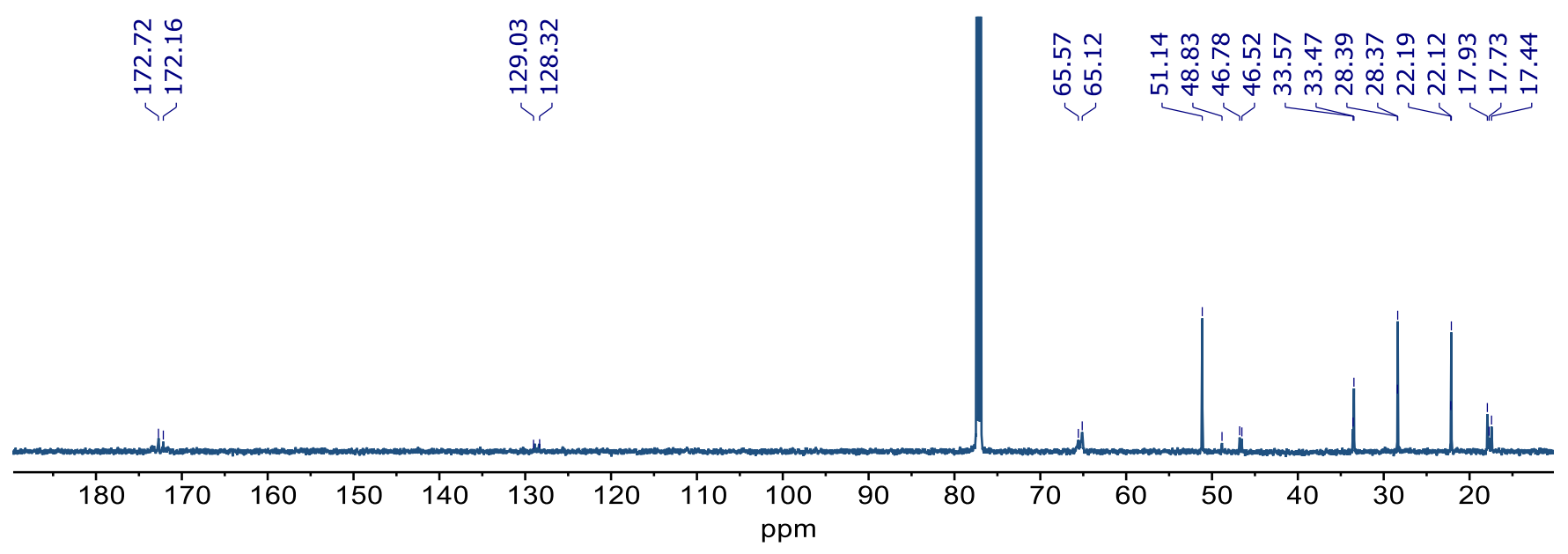

Figure S44. ${ }^{13} \mathrm{C}$ NMR of BnO-G5-Lin- $\mathrm{N}_{3}$ in $\mathrm{CDCl}_{3}$. 

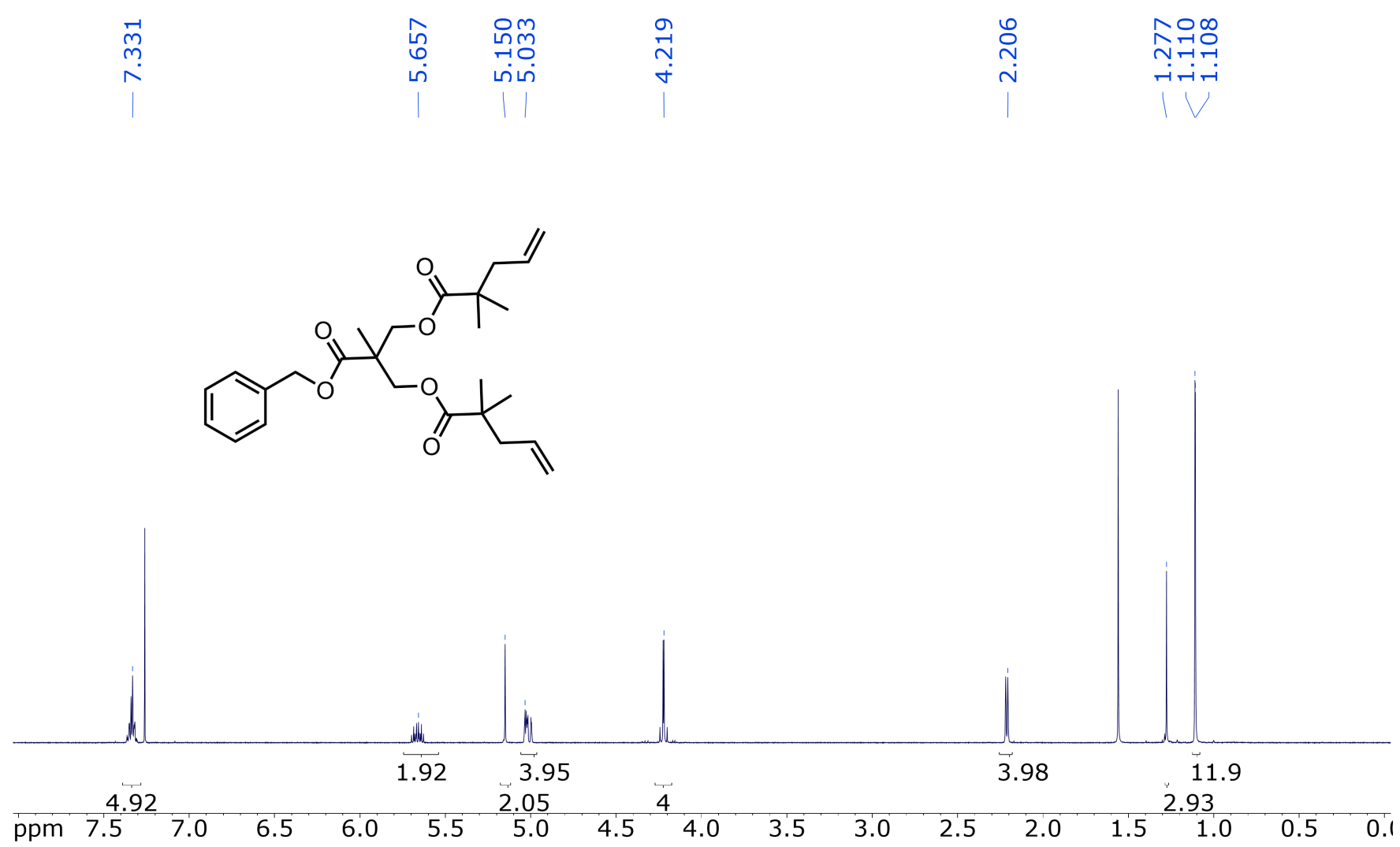

Figure S45. ${ }^{1} \mathrm{H}$ NMR of BnO-G1-(ene $)_{2}$ in $\mathrm{CDCl}_{3}$.

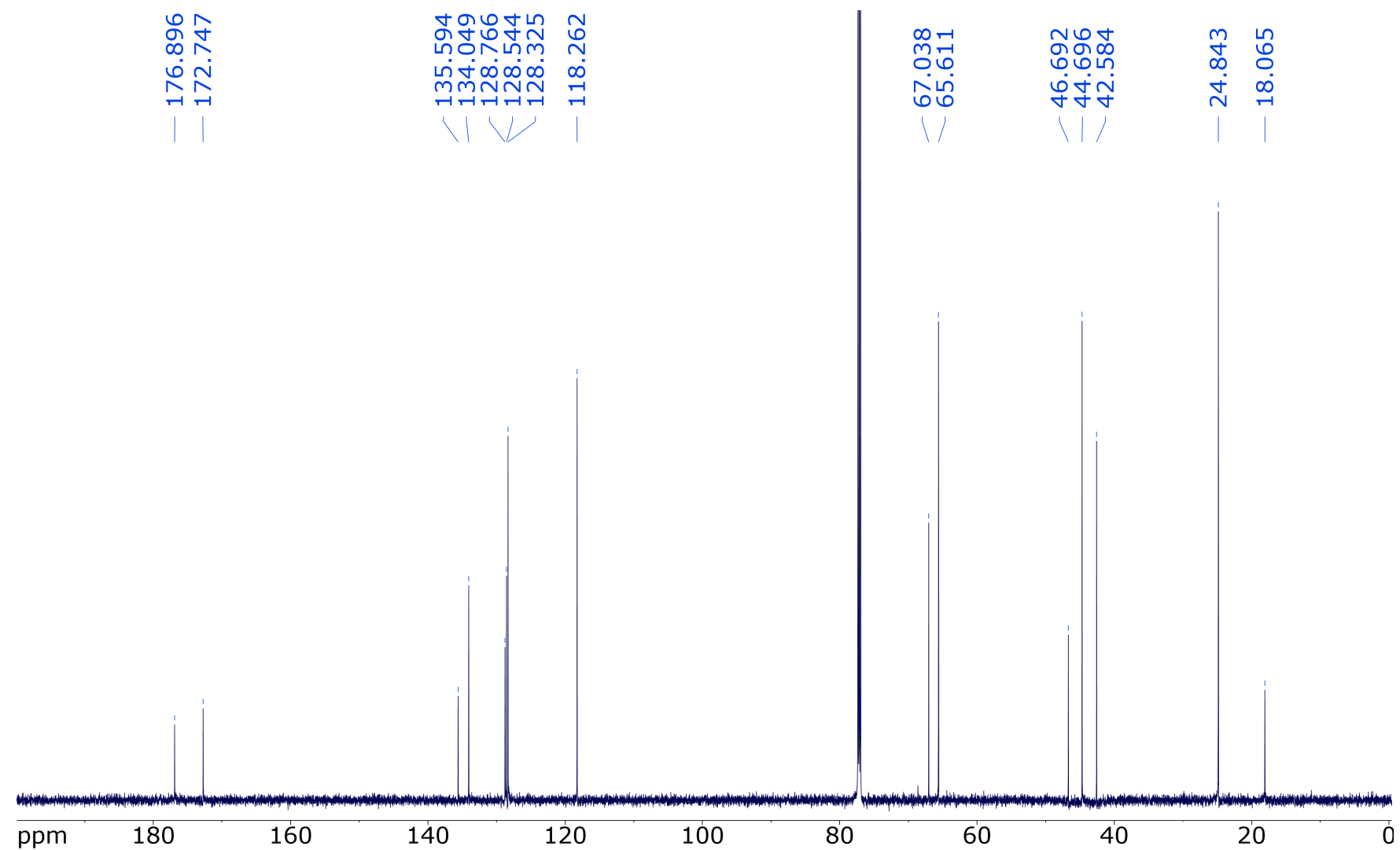


Figure S46. ${ }^{13} \mathrm{C}$ NMR of BnO-G1-(ene $)_{2}$ in $\mathrm{CDCl}_{3}$.

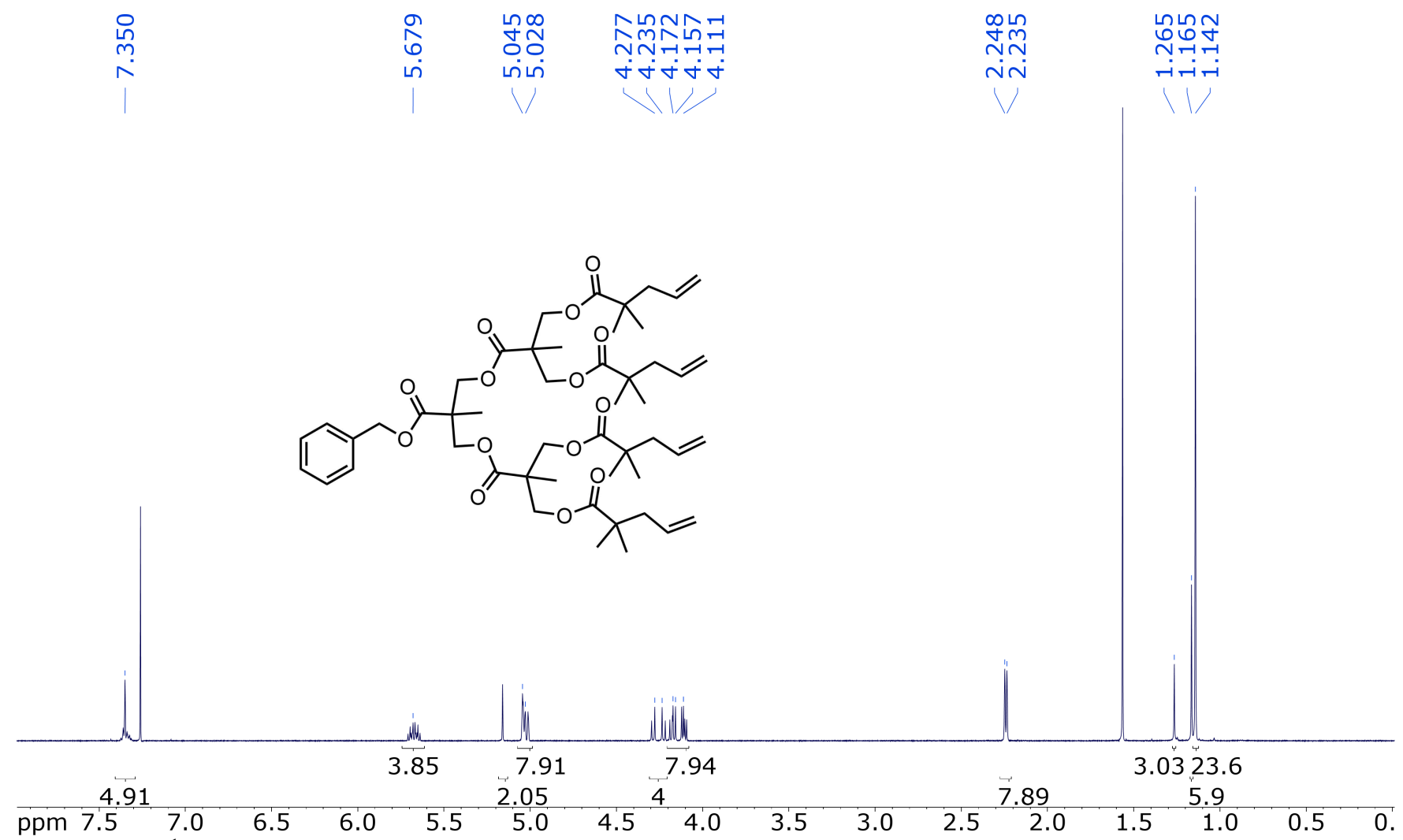

Figure S47. ${ }^{1} \mathrm{H} \mathrm{NMR}$ of $\mathrm{BnO}-\mathrm{G} 2-(\mathrm{ene})_{4}$ in $\mathrm{CDCl}_{3}$.

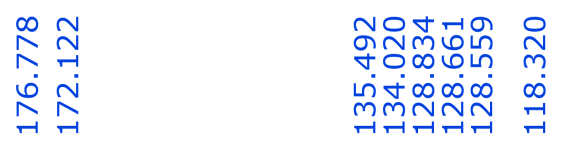

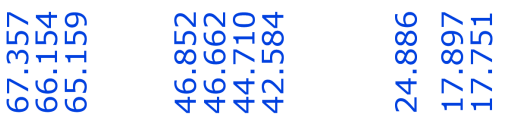

$1|\quad| V \mid$

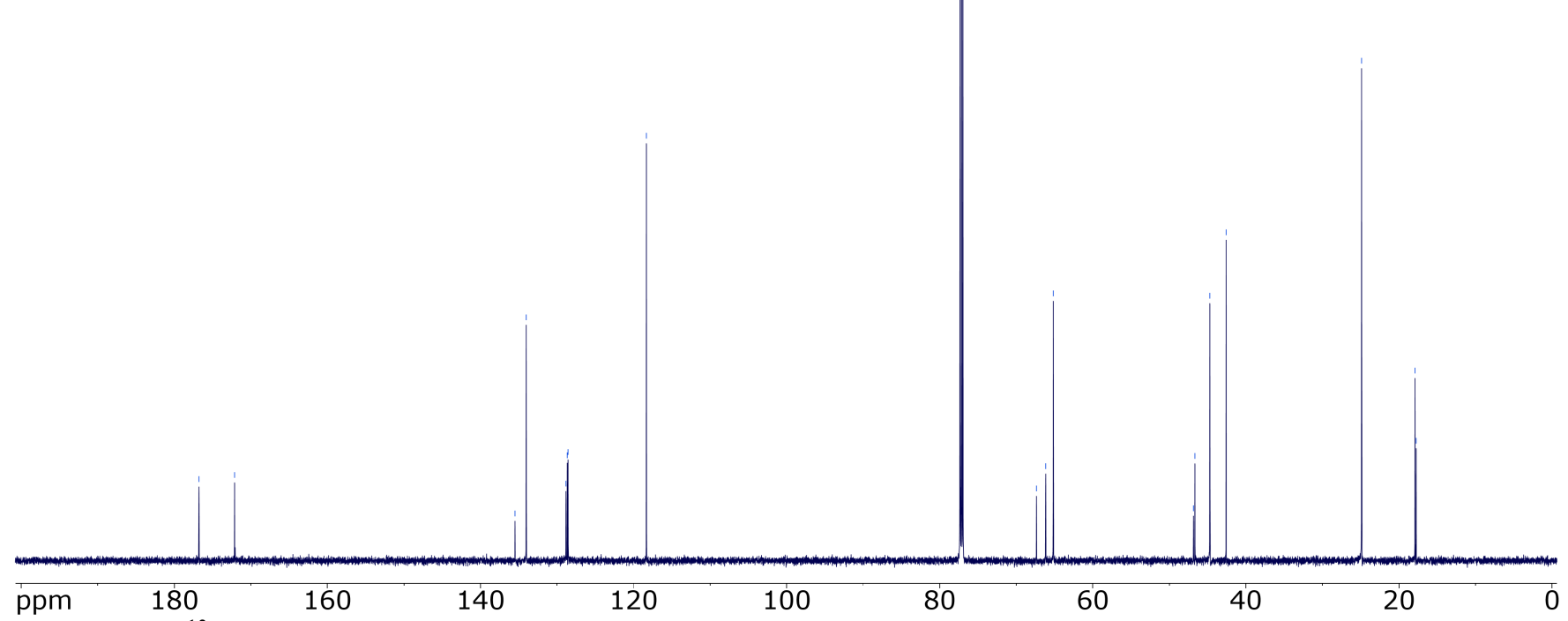

Figure S48. ${ }^{13} \mathrm{C}$ NMR of BnO-G2-(ene $)_{4}$ in $\mathrm{CDCl}_{3}$. 


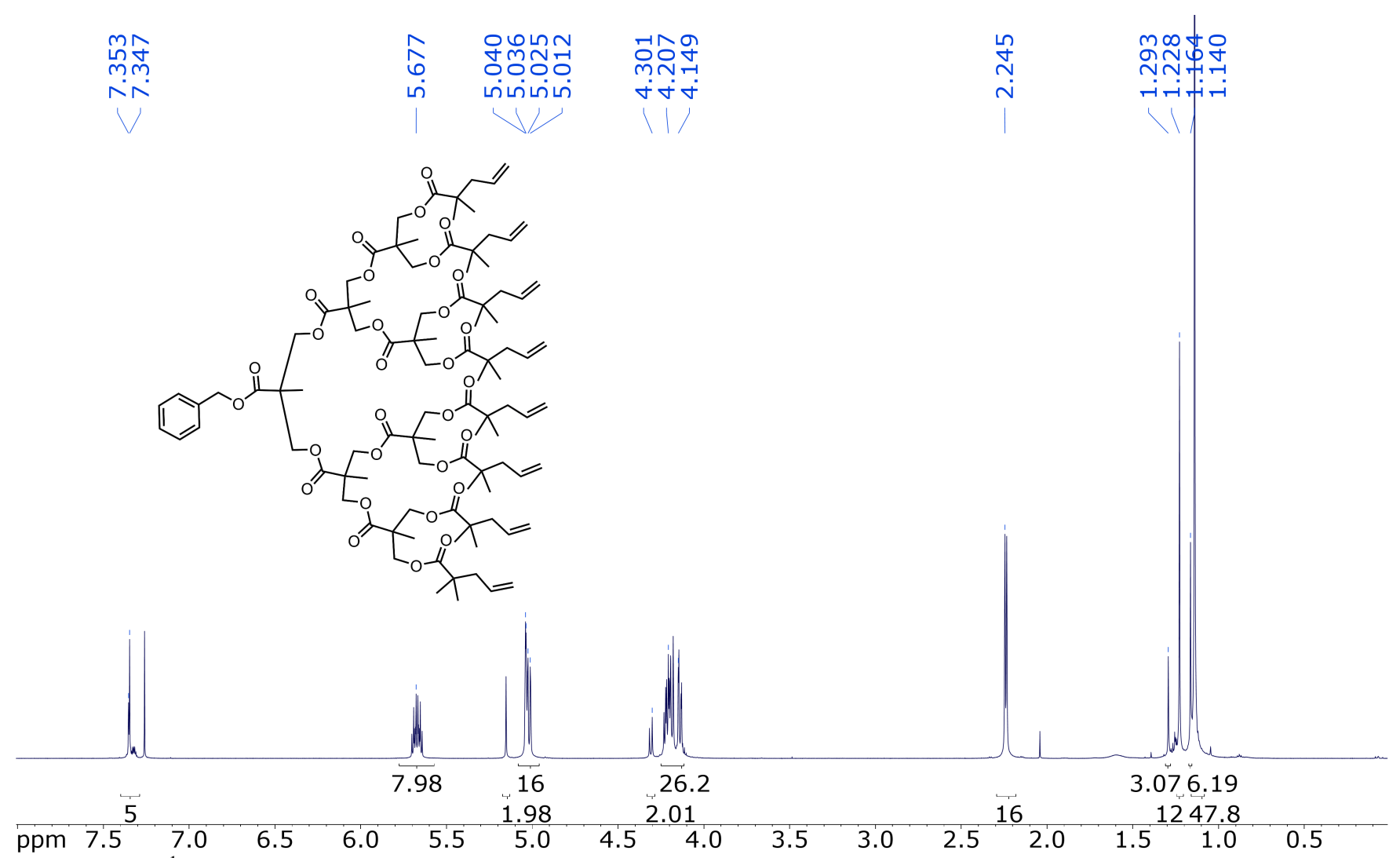

Figure S49. ${ }^{1} \mathrm{H}$ NMR of BnO-G3-(ene $)_{8}$ in $\mathrm{CDCl}_{3}$.

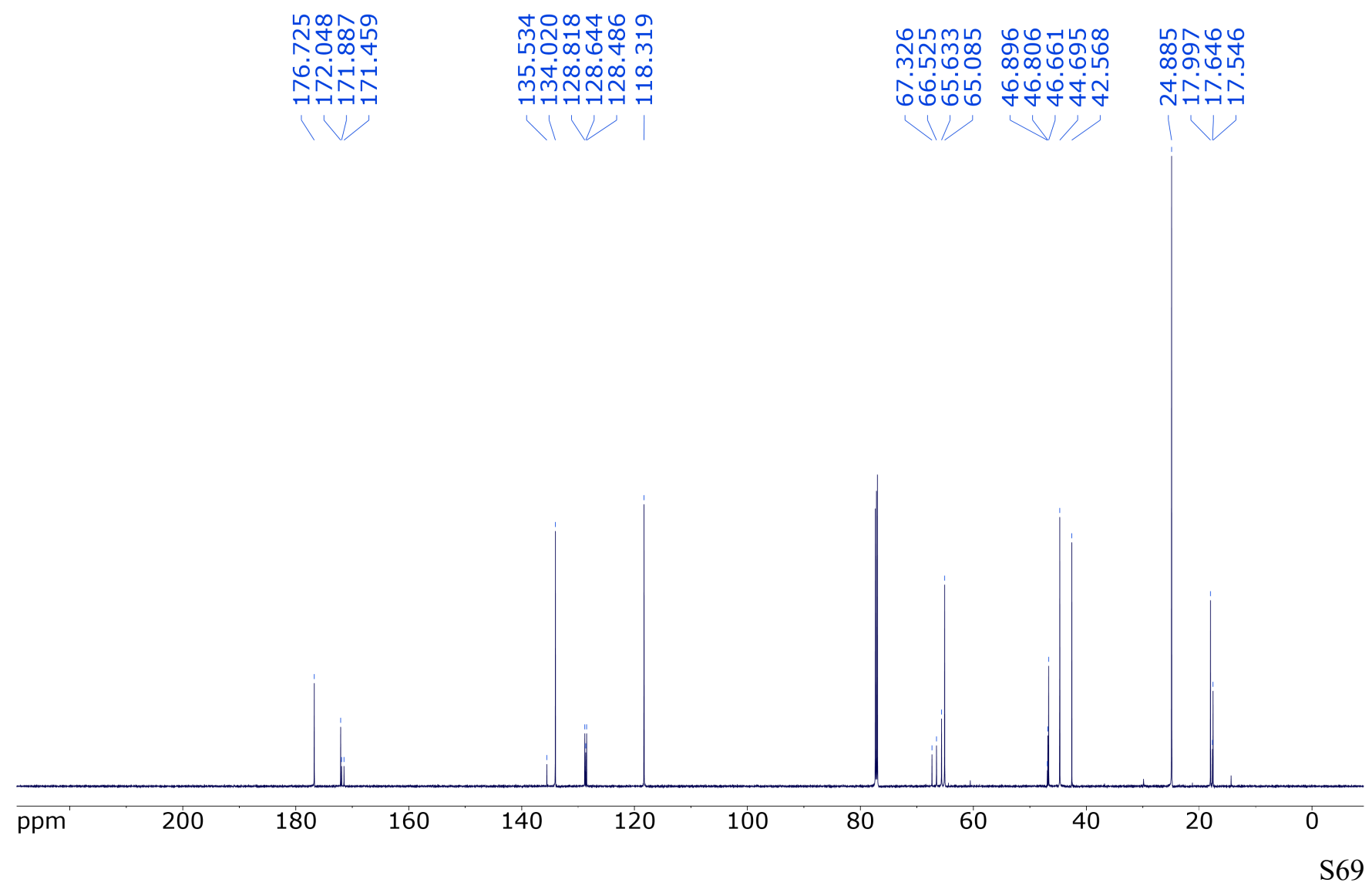


Figure S50. 13C NMR of BnO-G3-(ene) 8 in $\mathrm{CDCl}_{3}$.

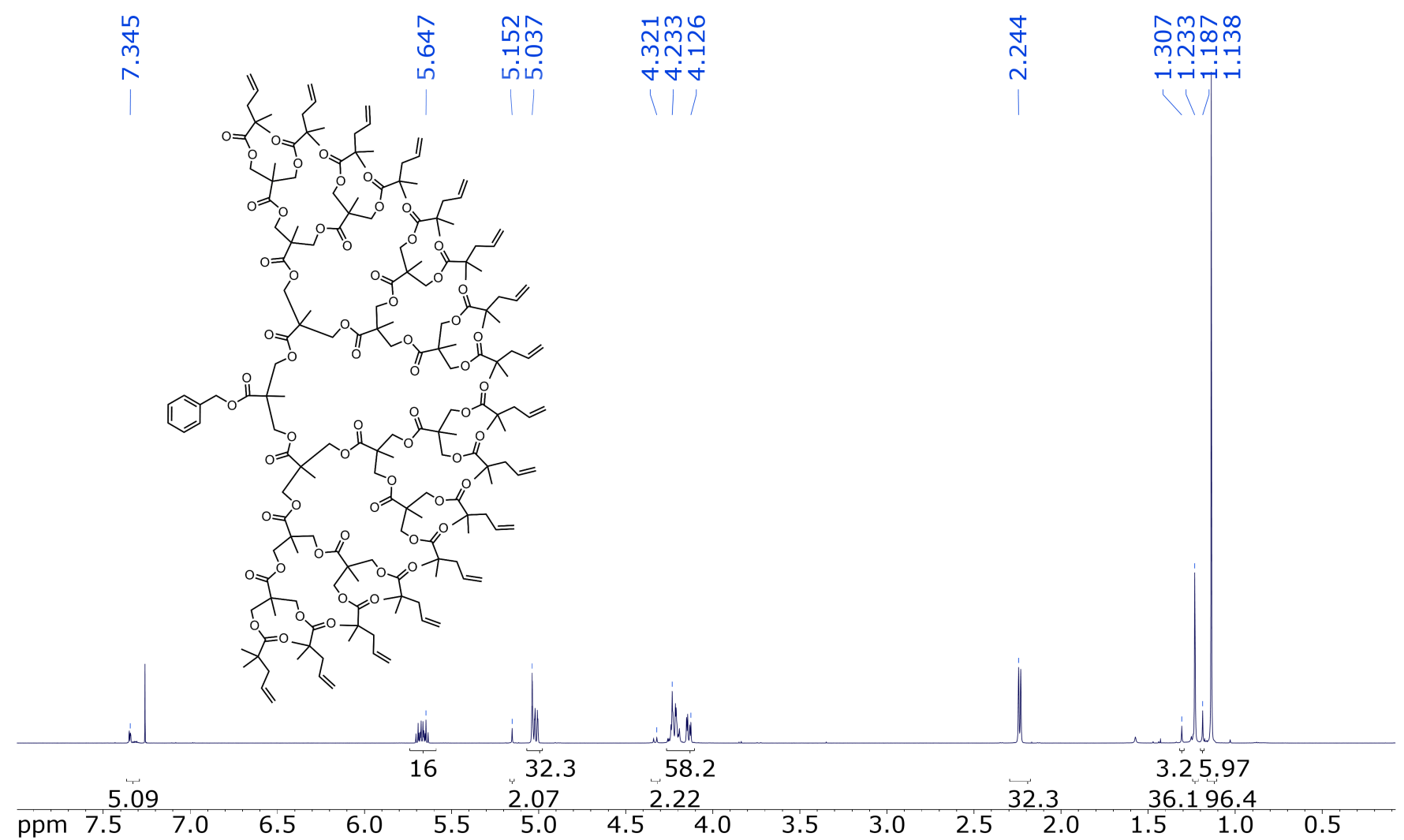

Figure S51. ${ }^{1} \mathrm{H}$ NMR of BnO-G4-(ene) ${ }_{16}$ in $\mathrm{CDCl}_{3}$.
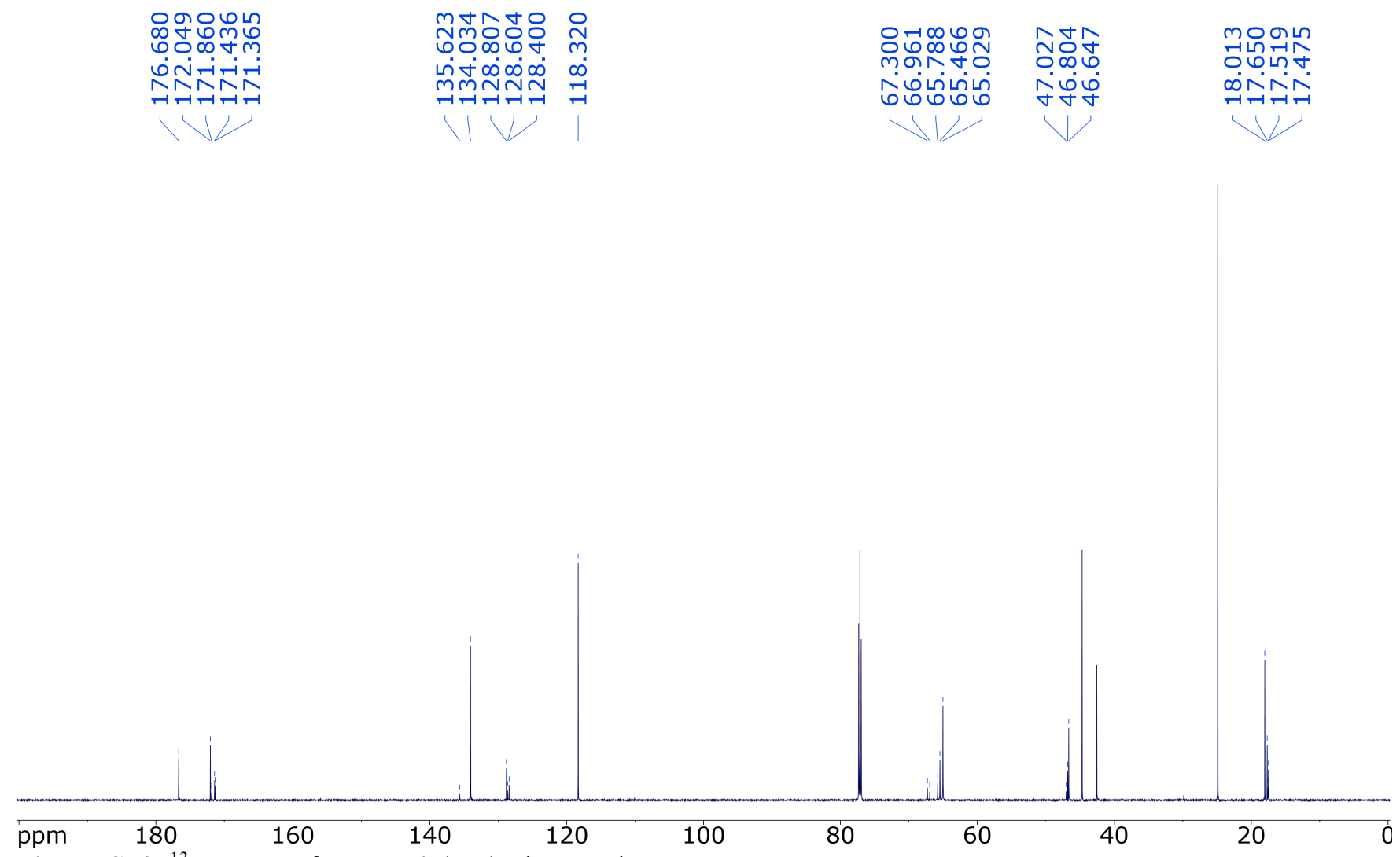

Figure S52. ${ }^{13} \mathrm{C}$ NMR of BnO-G4-(ene) ${ }_{16}$ in $\mathrm{CDCl}_{3}$. 


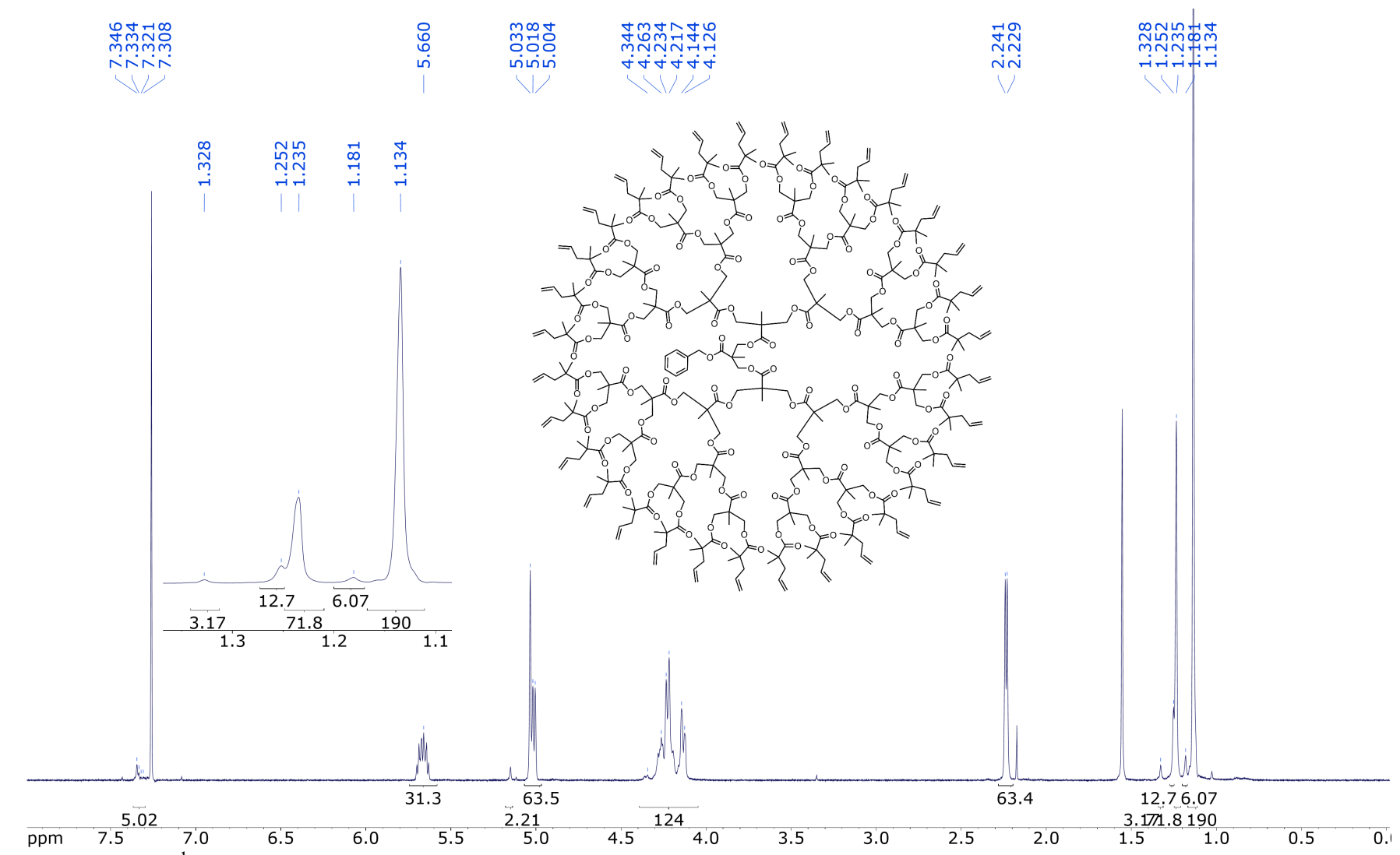

Figure S53. ${ }^{1} \mathrm{H}$ NMR of BnO-G5-(ene) $)_{32}$ in $\mathrm{CDCl}_{3}$. 


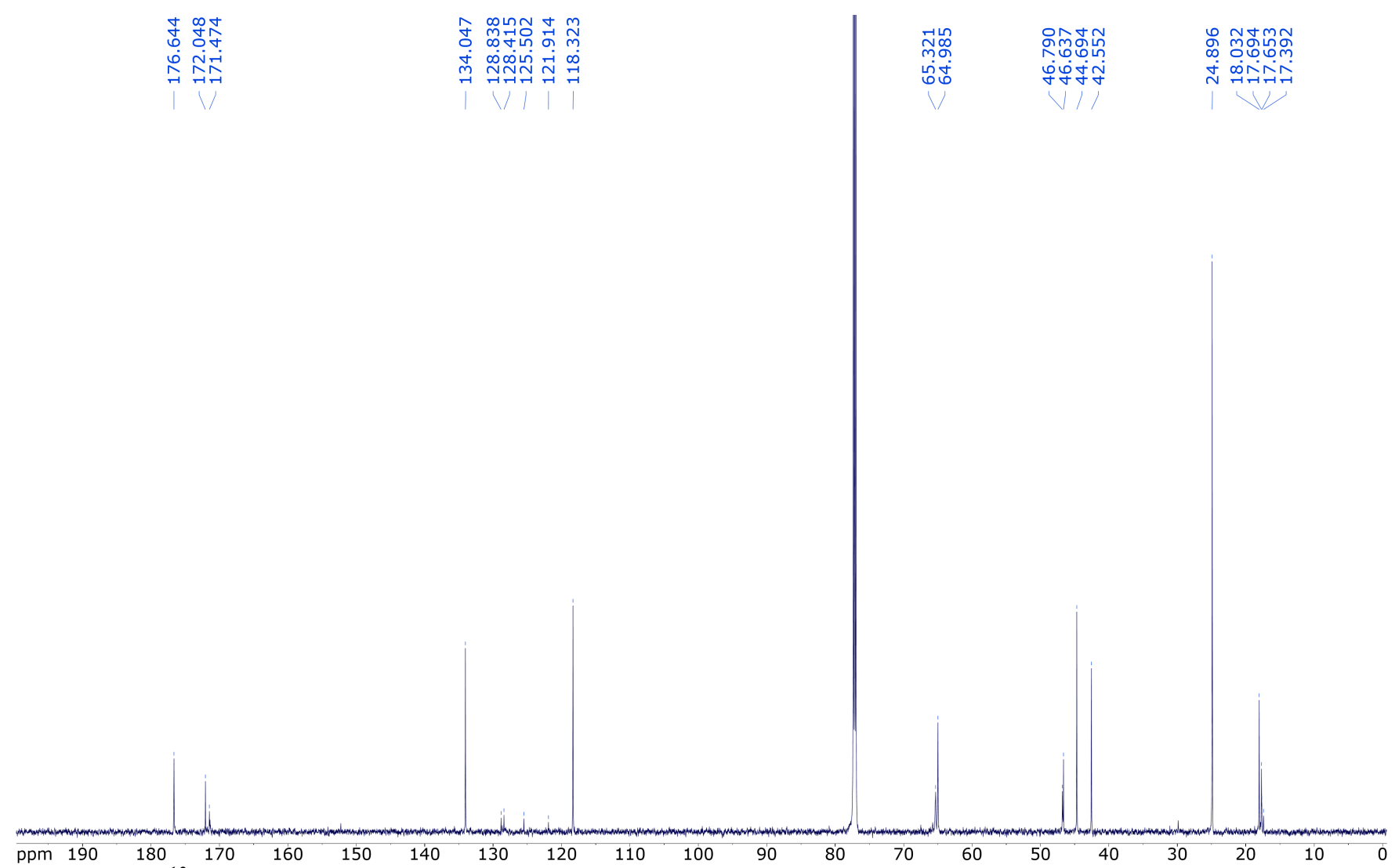

Figure S54. ${ }^{13} \mathrm{C}$ NMR of BnO-G5-(ene) $)_{32}$ in $\mathrm{CDCl}_{3}$.

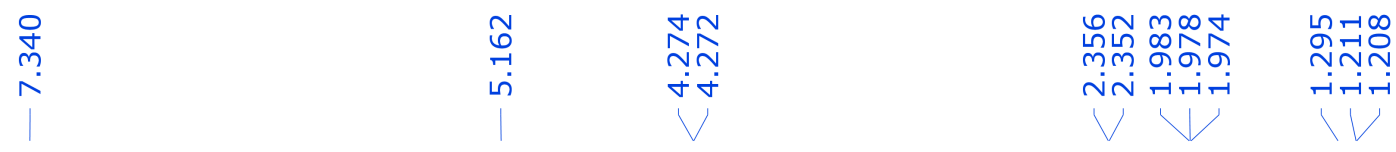

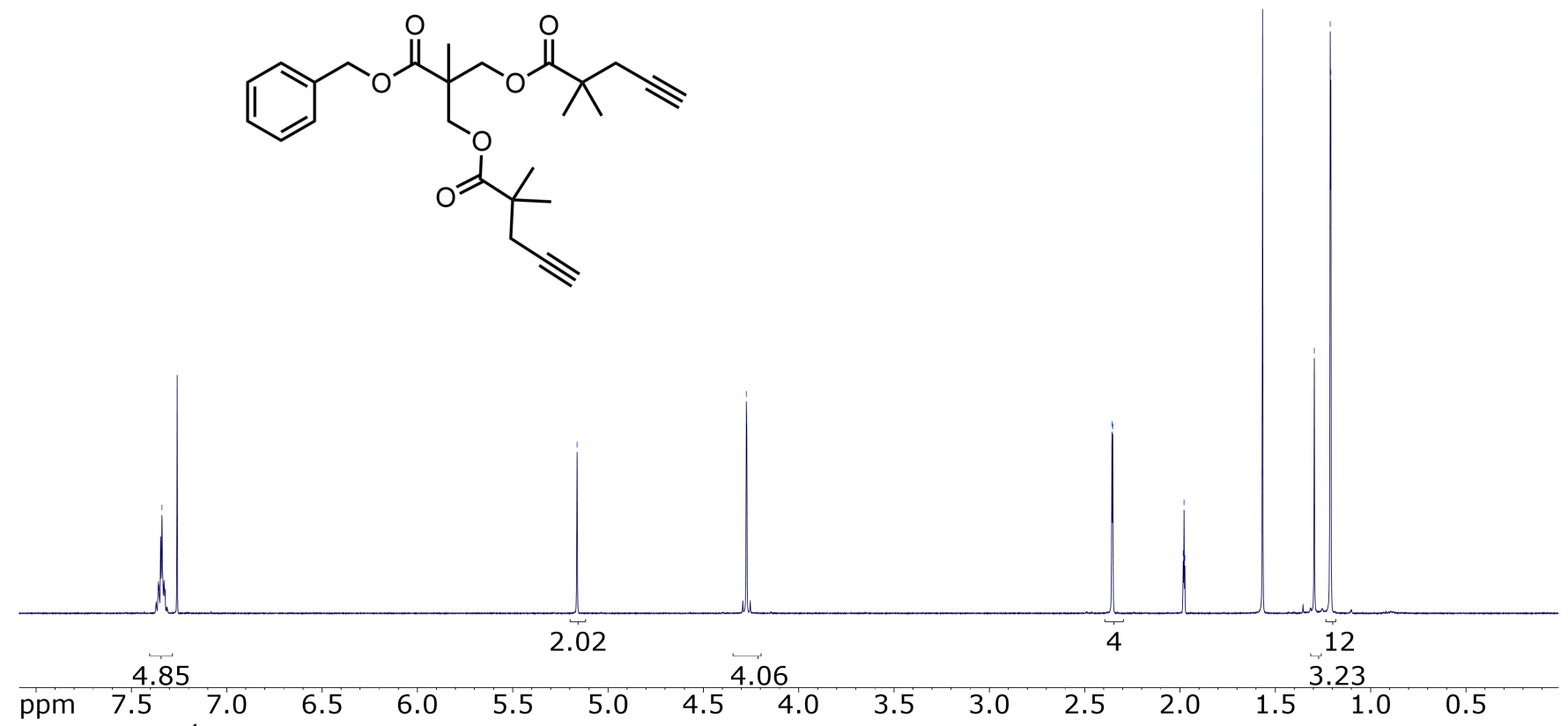

Figure S55. ${ }^{1} \mathrm{H}$ NMR of BnO-G1-(yne) $)_{2}$ in $\mathrm{CDCl}_{3}$. 


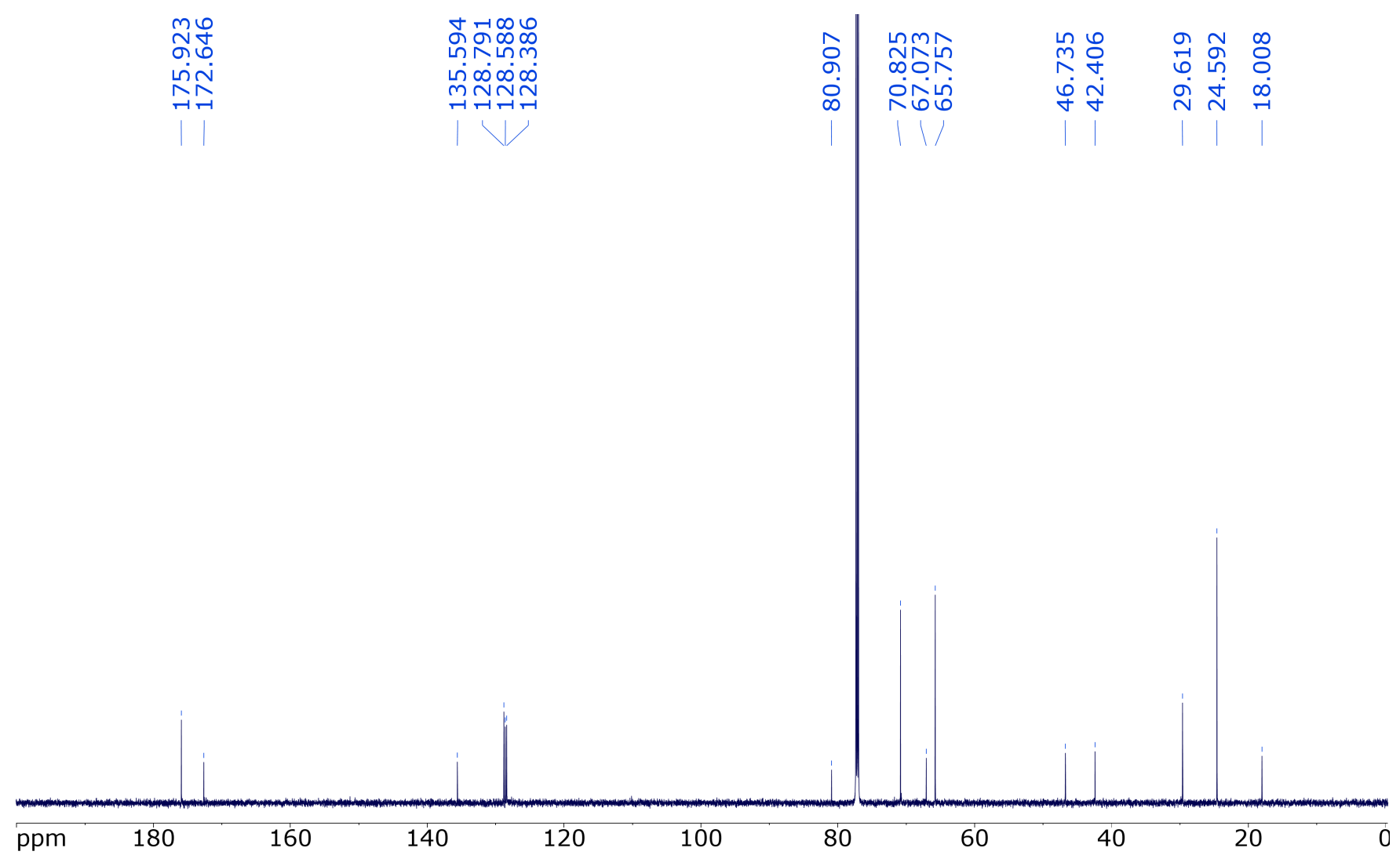

Figure S56. 13C NMR of BnO-G1-(yne) ${ }_{2}$ in $\mathrm{CDCl}_{3}$.

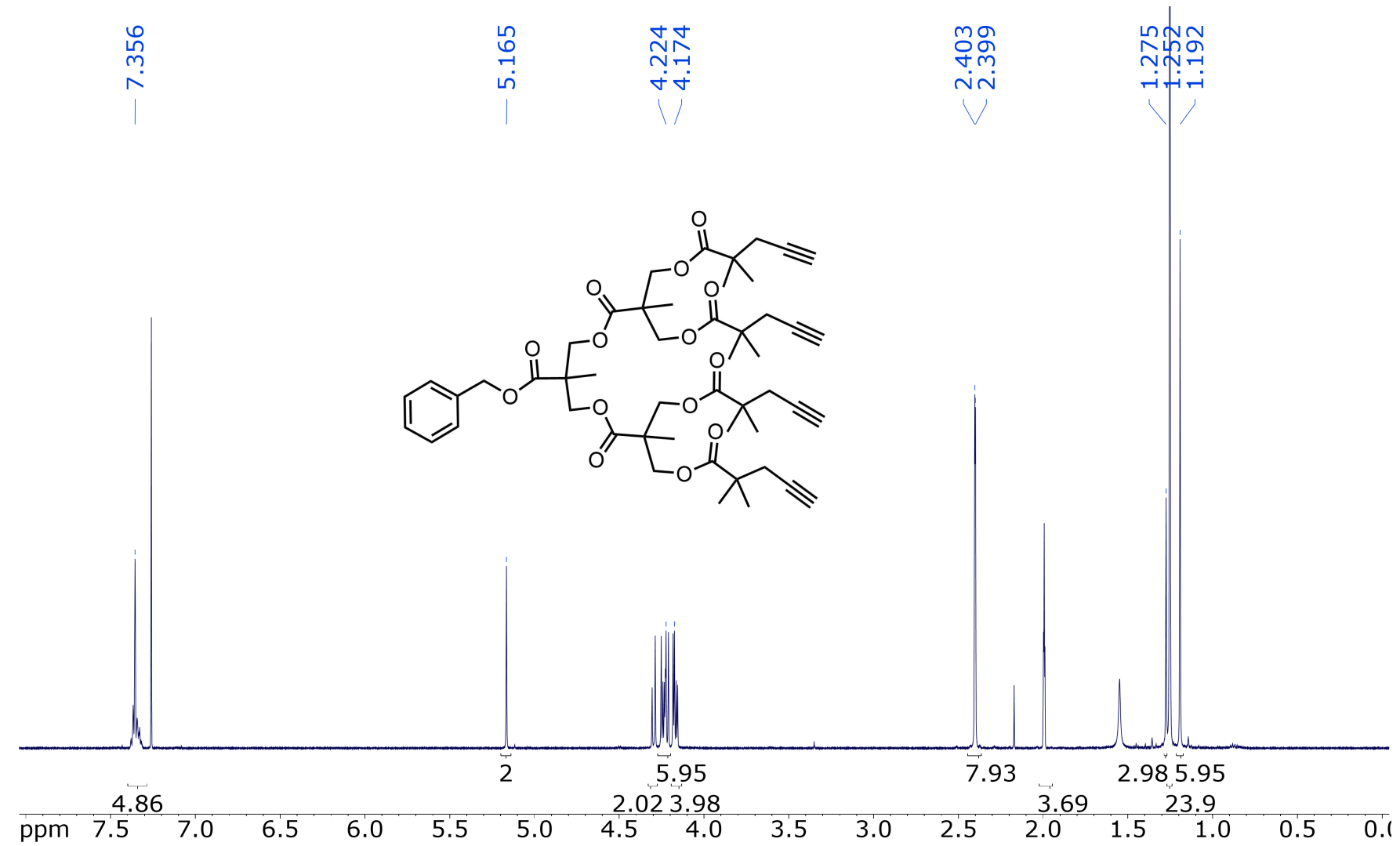

Figure S57. ${ }^{1} \mathrm{H}$ NMR of BnO-G2-(yne) $)_{4}$ in $\mathrm{CDCl}_{3}$. 


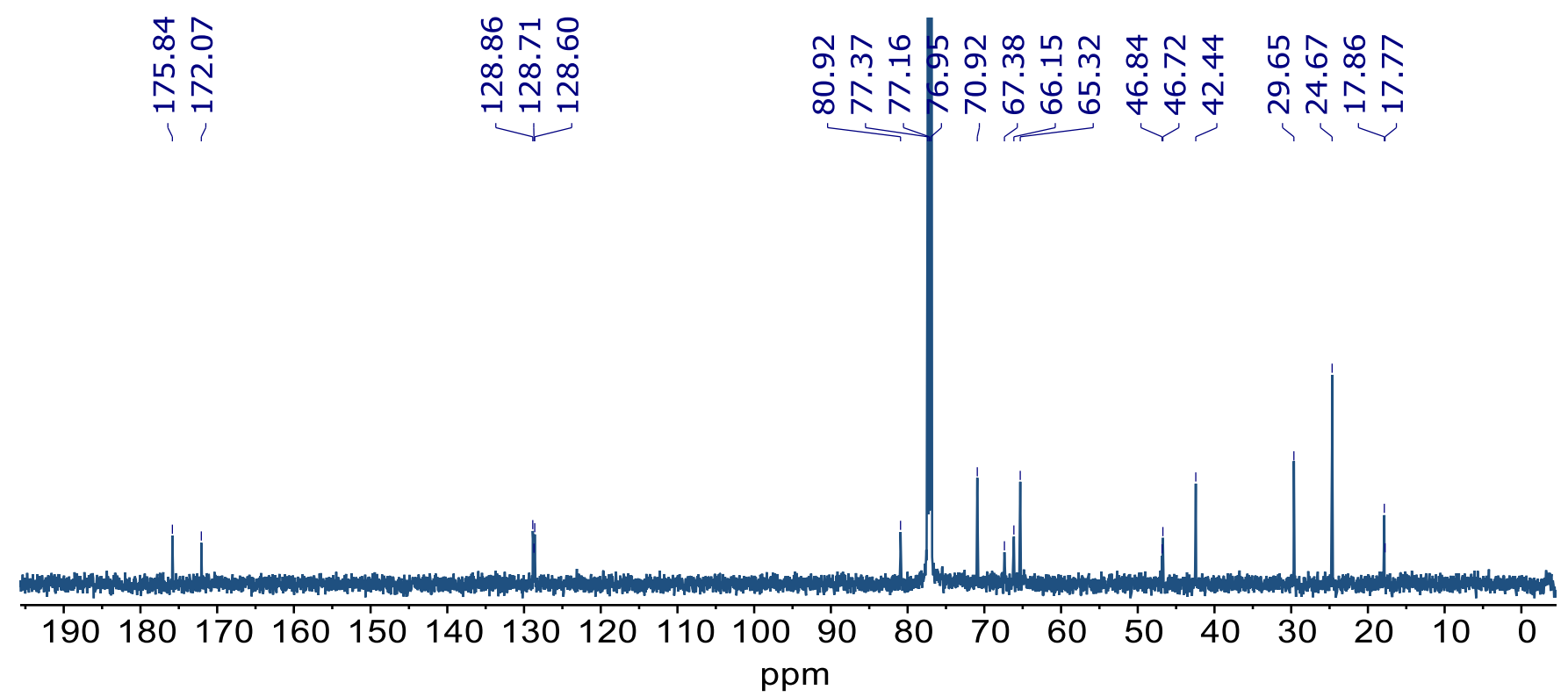

Figure S58. 13C NMR of BnO-G2-(yne) $)_{4}$ in $\mathrm{CDCl}_{3}$.

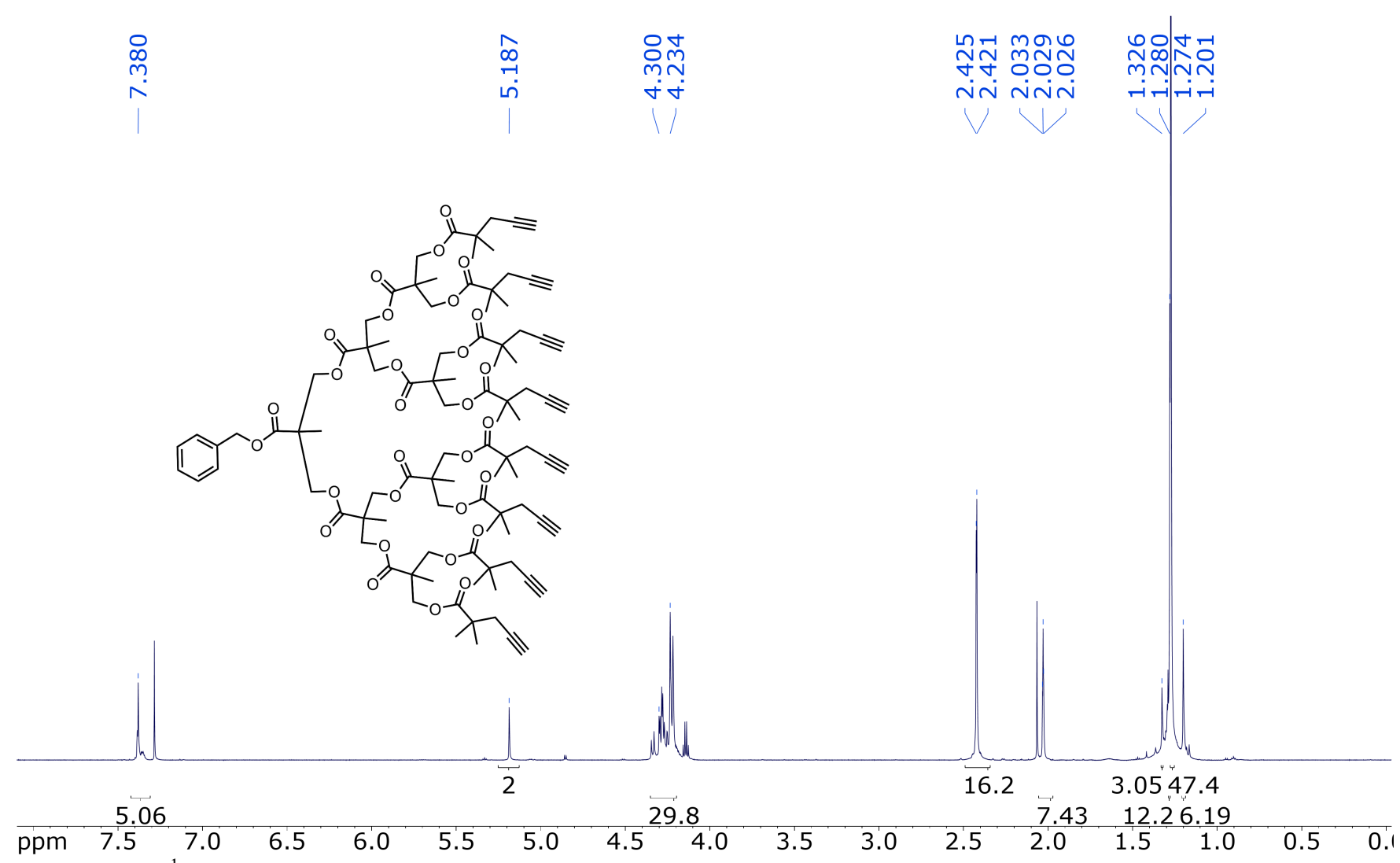

Figure S59. ${ }^{1} \mathrm{H}$ NMR of BnO-G3-(yne) $)_{8}$ in $\mathrm{CDCl}_{3}$. 


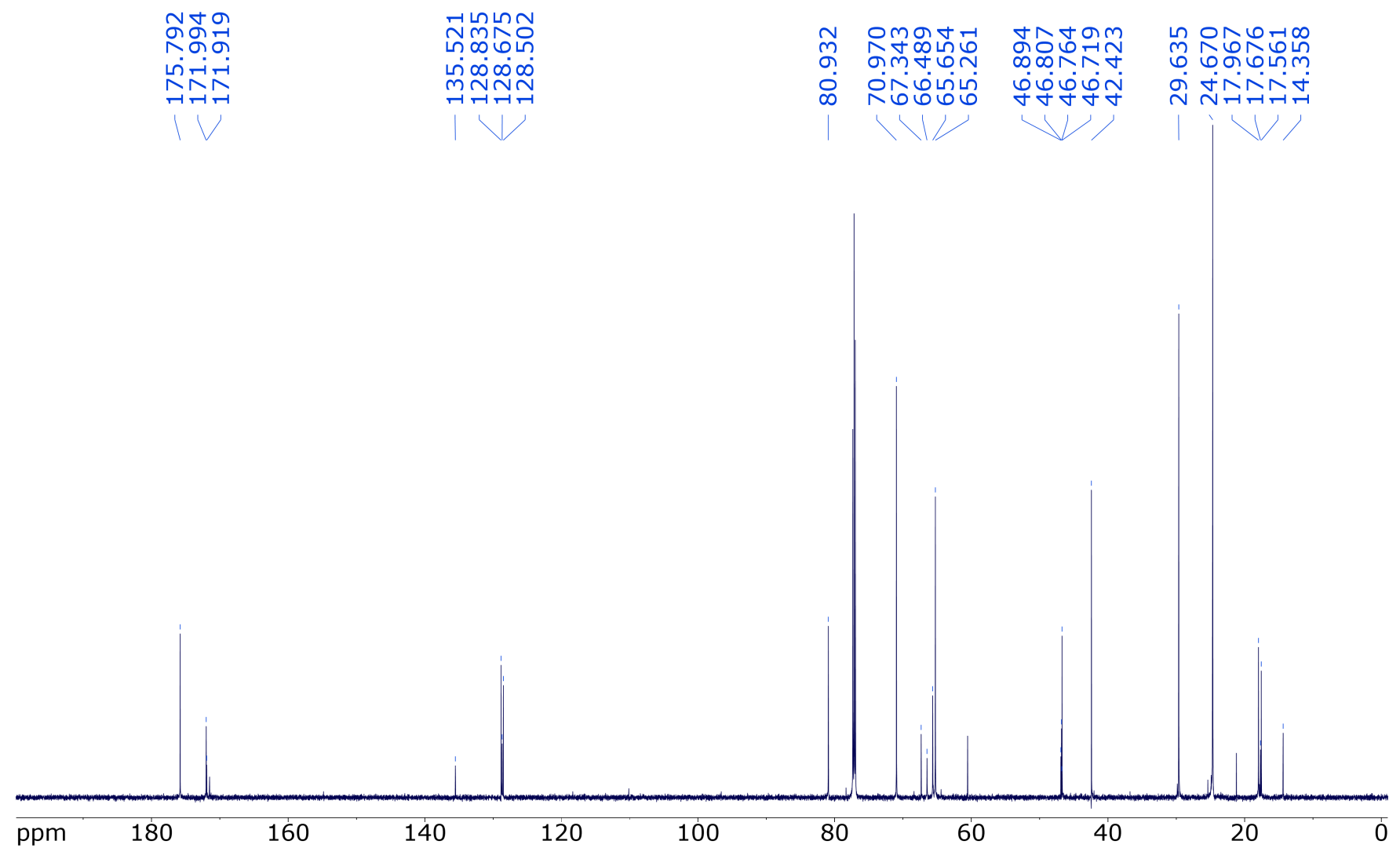

Figure S60. 13C NMR of BnO-G3-(yne) 8 in $\mathrm{CDCl}_{3}$.

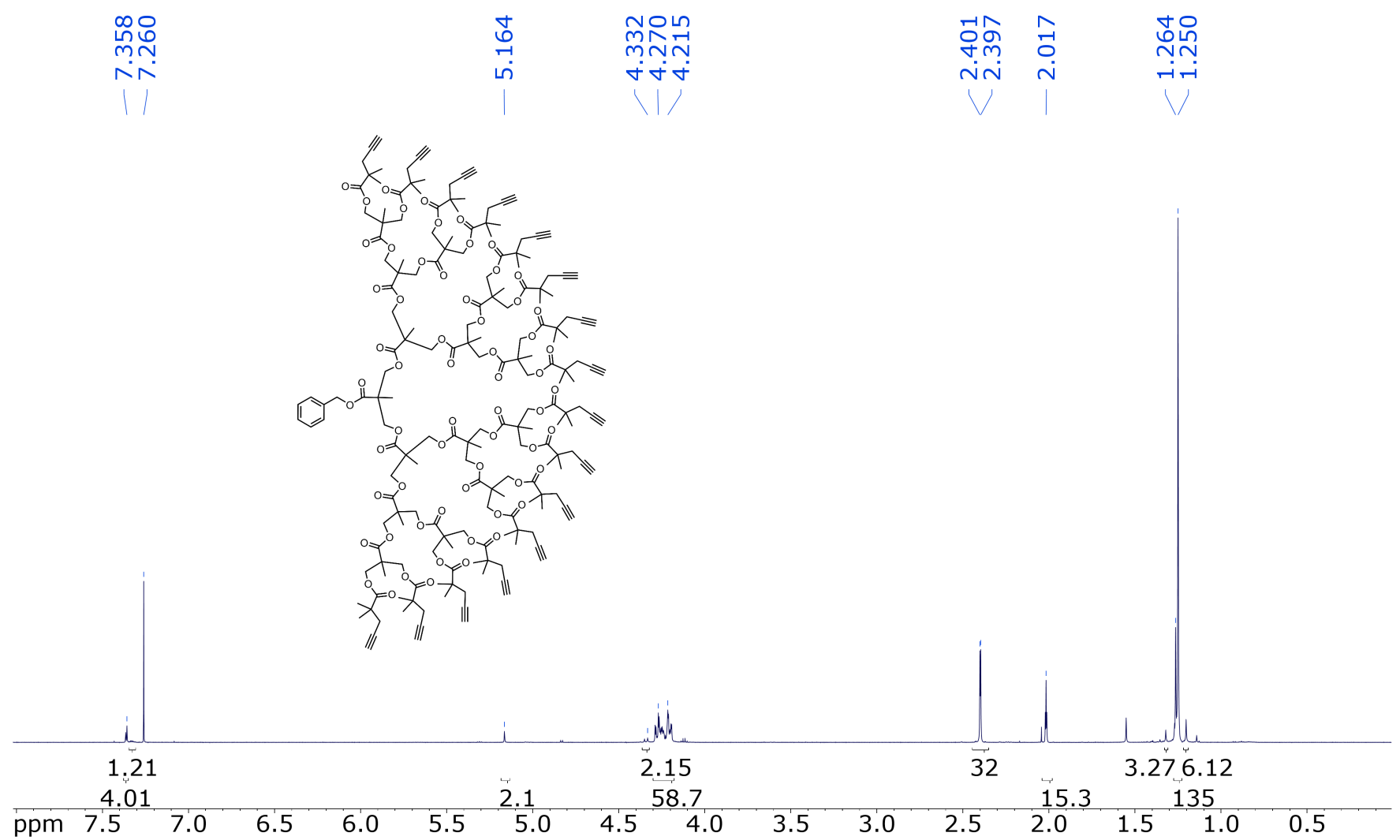

Figure S61. ${ }^{1} \mathrm{H}$ NMR of BnO-G4-(yne) ${ }_{16}$ in $\mathrm{CDCl}_{3}$. 


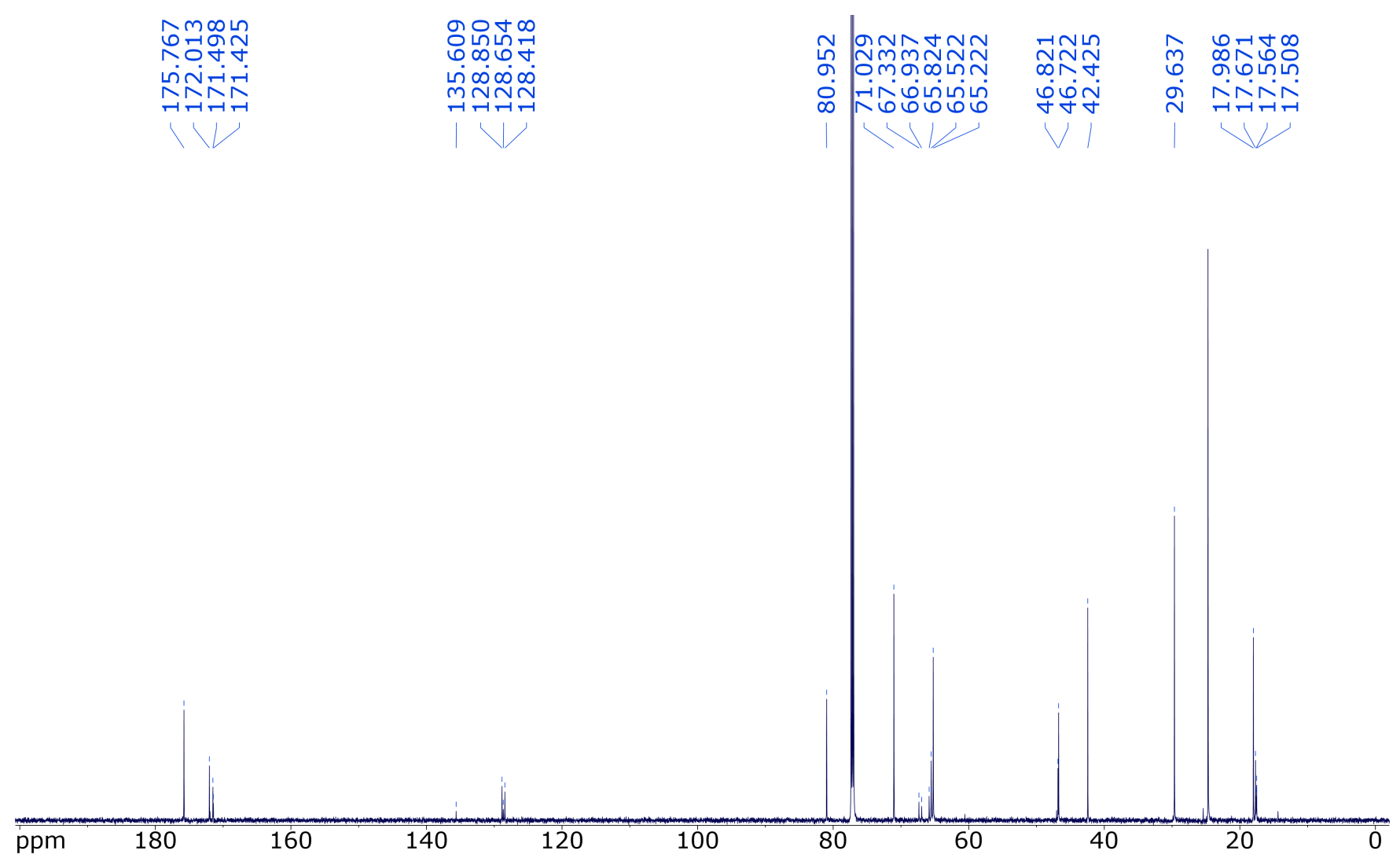

Figure S62. ${ }^{13} \mathrm{C}$ NMR of BnO-G4-(yne) ${ }_{16}$ in $\mathrm{CDCl}_{3}$.

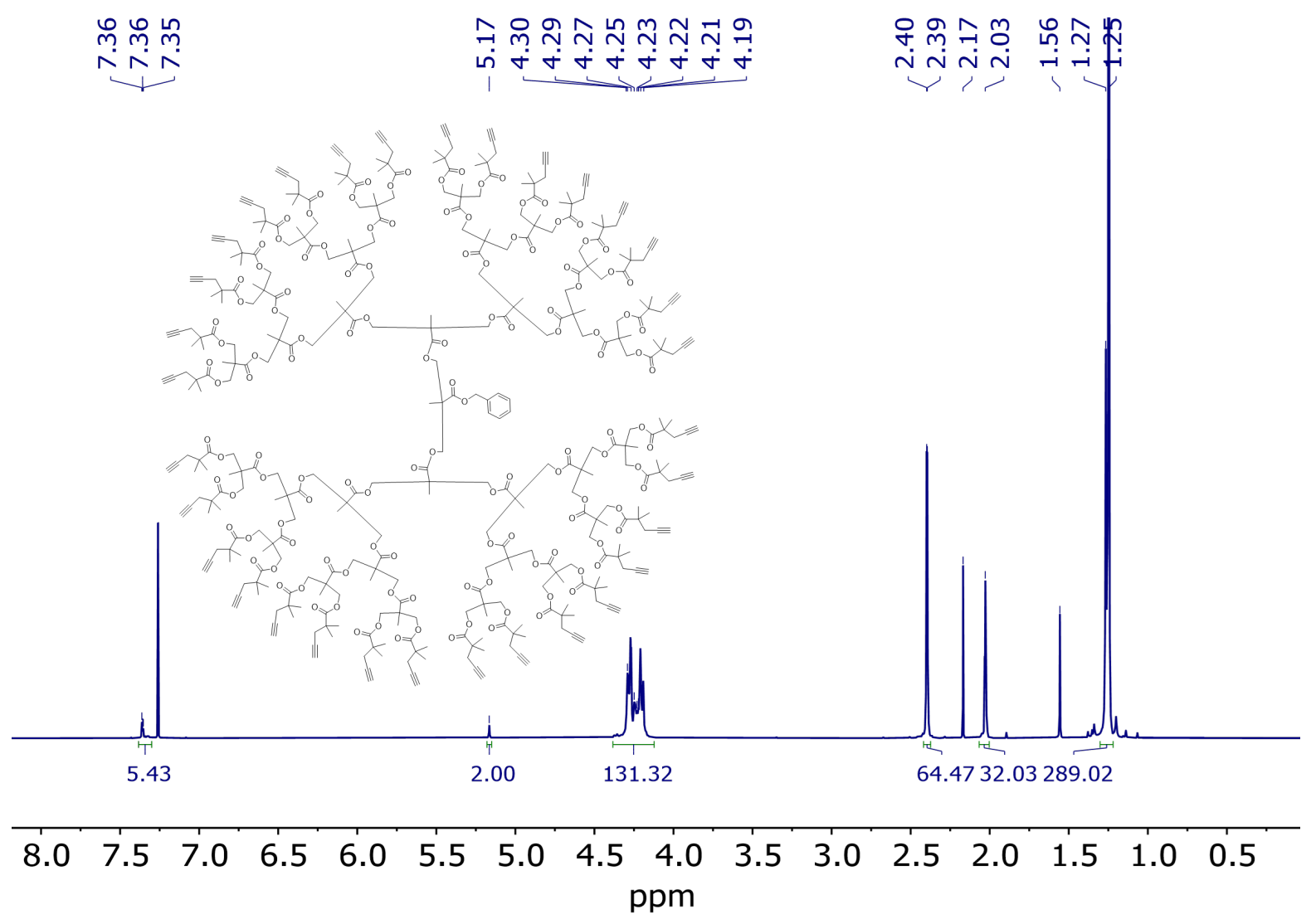


Figure S63. ${ }^{1} \mathrm{H}$ NMR of BnO-G5-(yne $)_{32}$ in $\mathrm{CDCl}_{3}$.

\begin{tabular}{|c|c|c|c|c|}
\hline 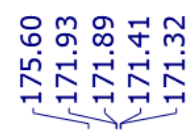 & 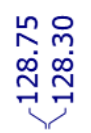 & $\begin{array}{l}\dot{1} \\
\infty \\
\infty \\
\infty \\
1\end{array}$ & 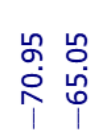 & 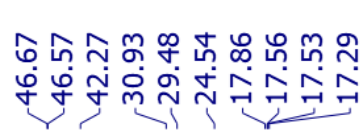 \\
\hline
\end{tabular}

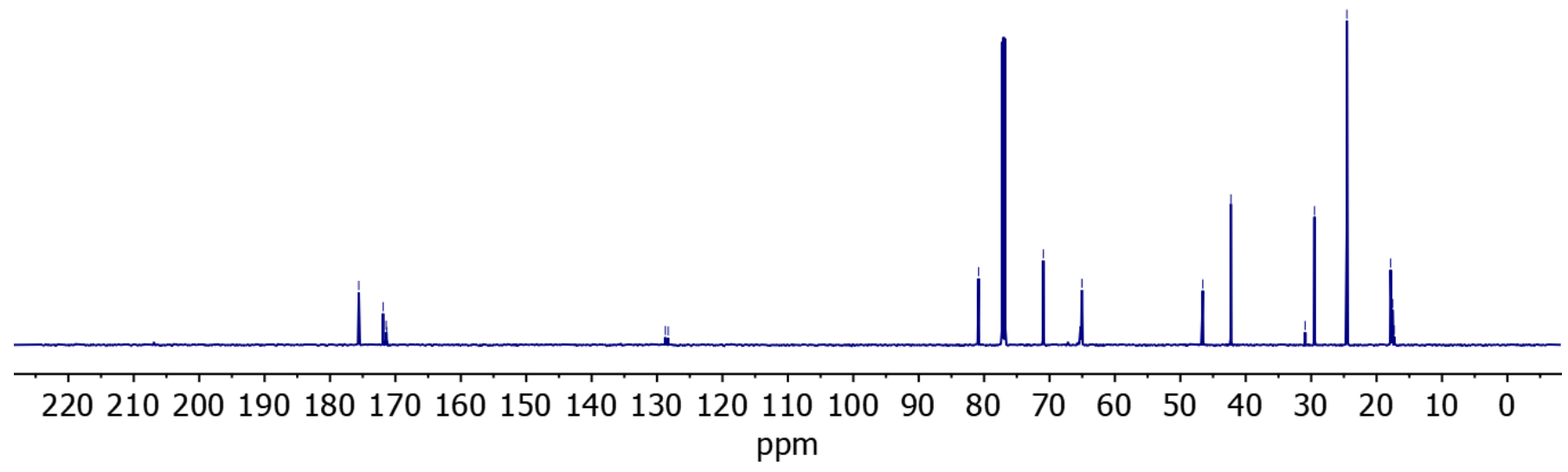

Figure S64. ${ }^{13} \mathrm{C}$ NMR of BnO-G5-(yne $)_{32}$ in $\mathrm{CDCl}_{3}$ 


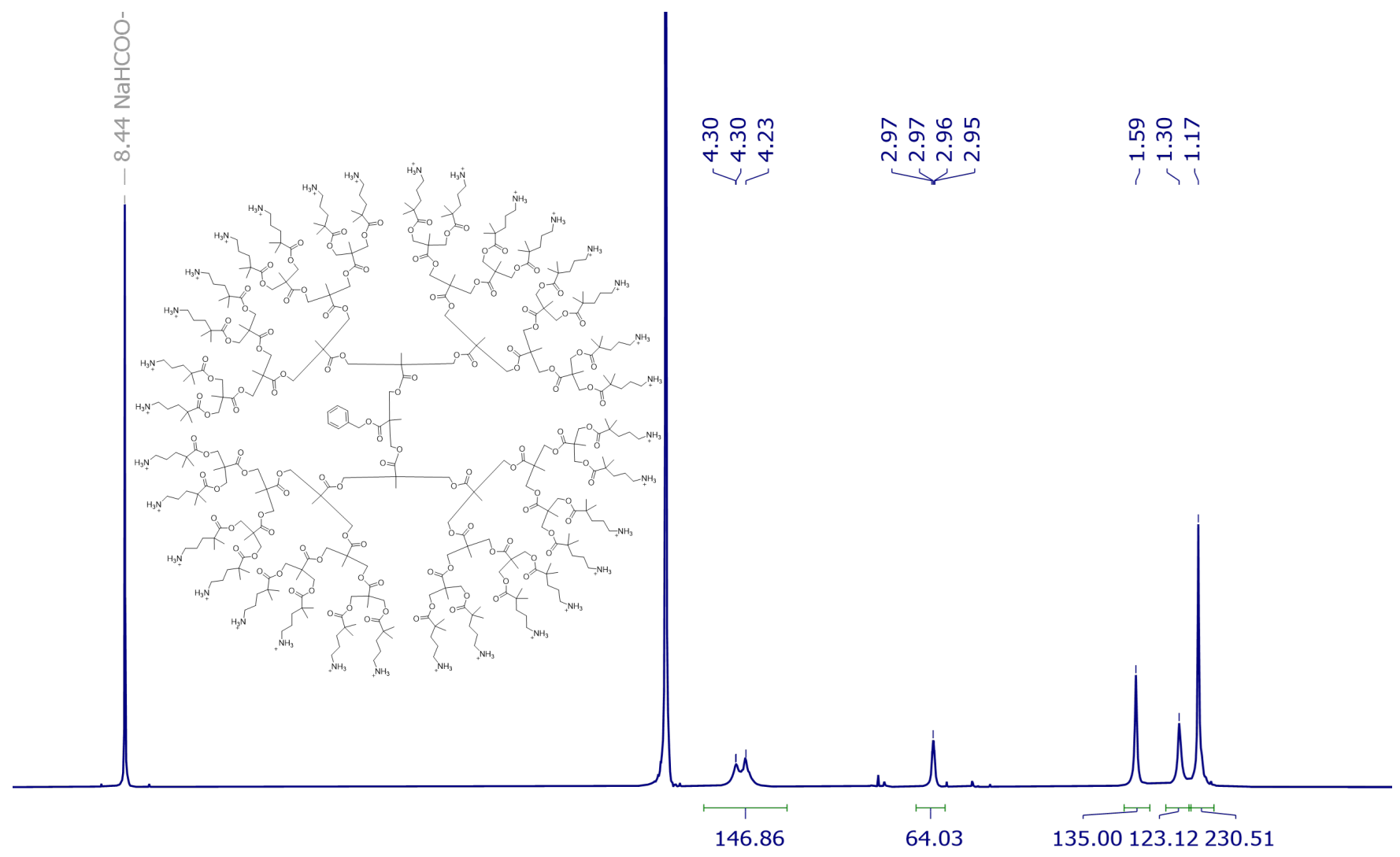

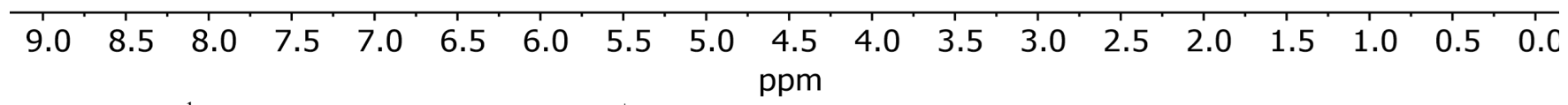

Figure S65. ${ }^{1} \mathrm{H}$ NMR of BnO-G5-(Neo- $\left.\mathrm{NH}_{3}{ }^{+} \mathrm{TFA}^{-}\right)_{32}$ in $\mathrm{D}_{2} \mathrm{O}$ with $\mathrm{NaHCOO}^{-}$as reference. TFA anions have been omitted from the structure.

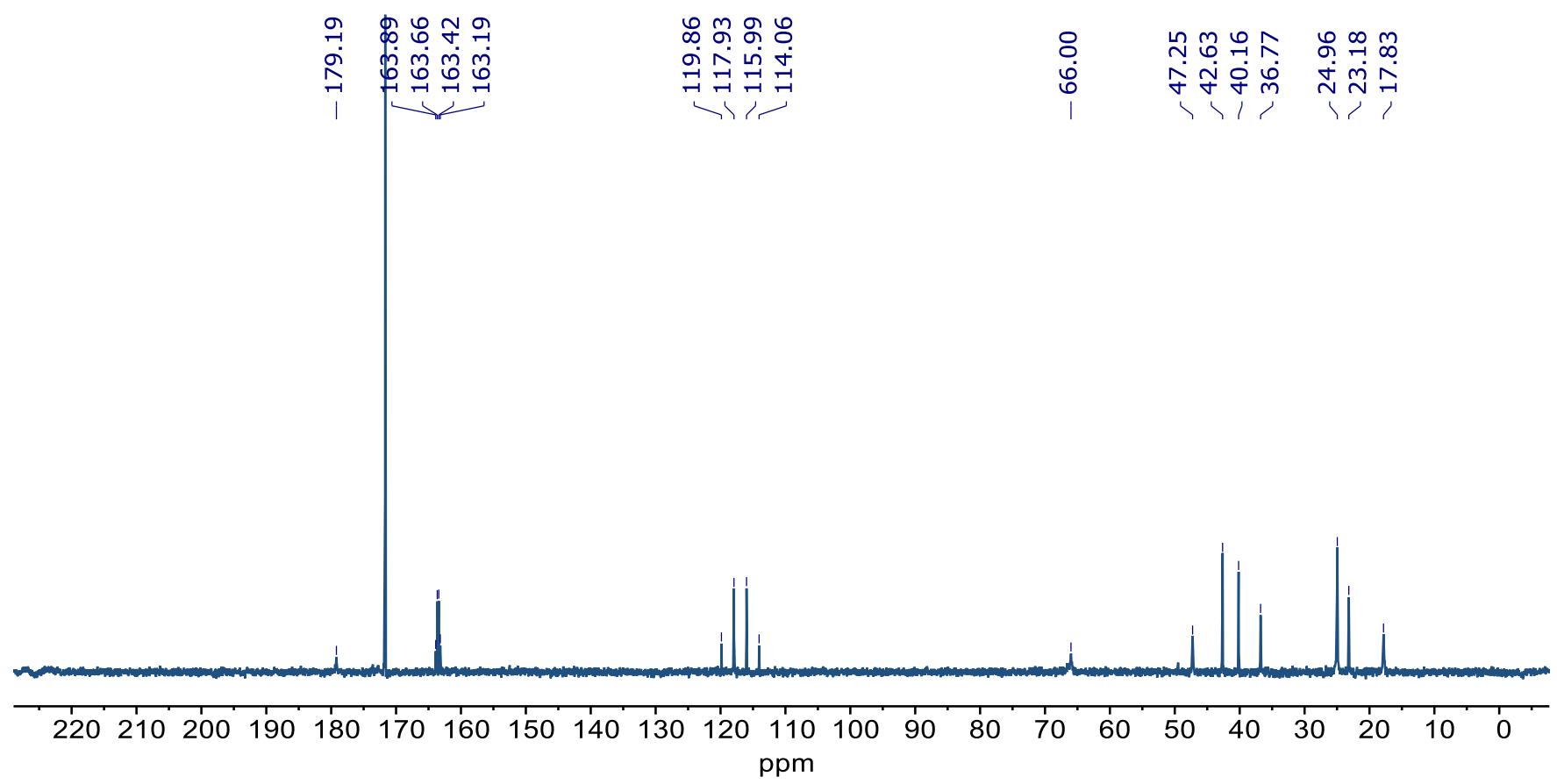

Figure S66. ${ }^{13} \mathrm{C}$ NMR of BnO-G5-(Neo-NH$\left.{ }_{3}{ }^{+} \mathrm{TFA}^{-}\right)_{32}$ in $\mathrm{D}_{2} \mathrm{O}$ with $\mathrm{NaHCOO}^{-}(\delta=171.67 \mathrm{ppm})$ as reference. 


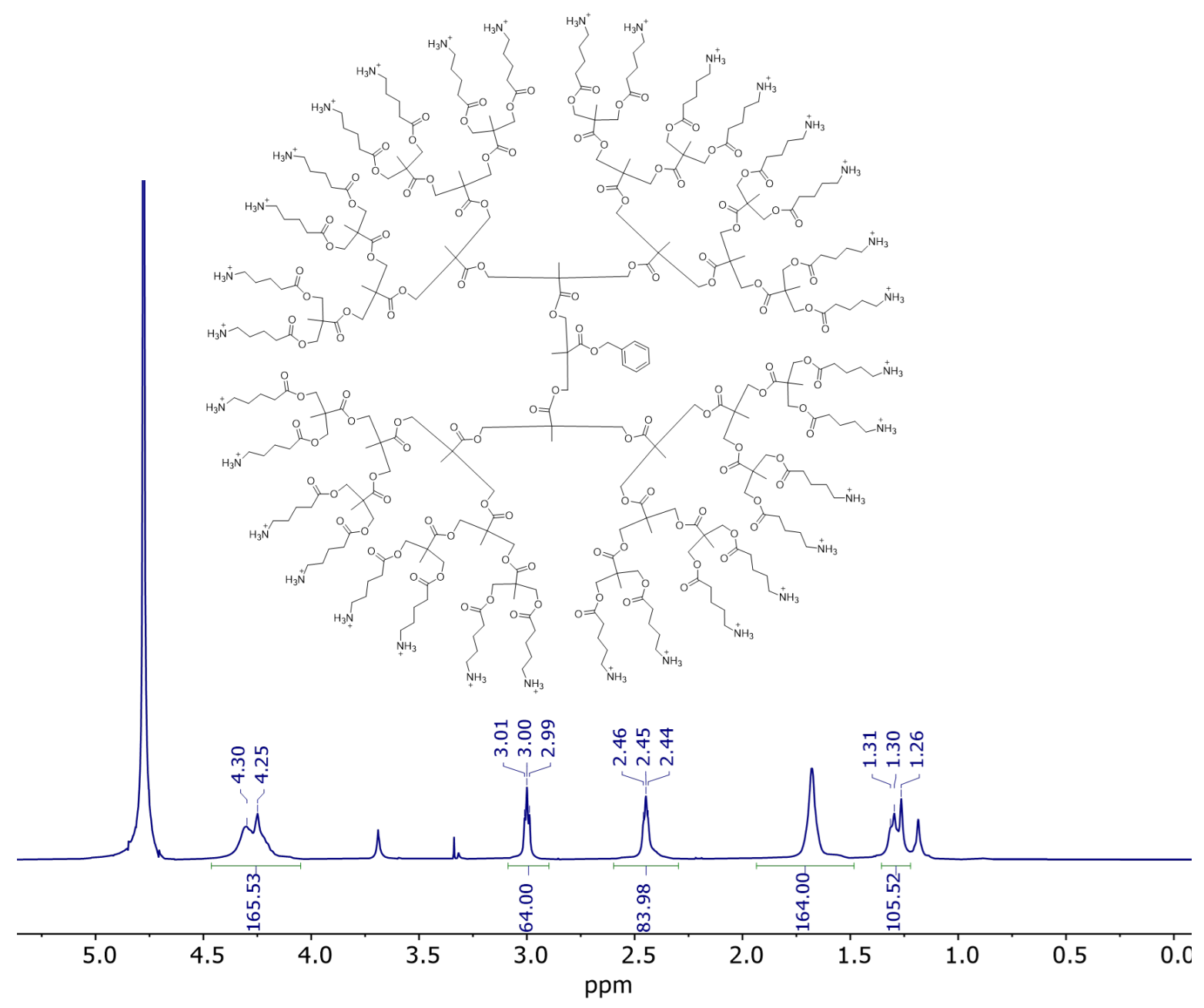

Figure S67. ${ }^{1} \mathrm{H}$ NMR of BnO-G5-(Lin- $\left.\mathrm{NH}_{3}{ }^{+} \mathrm{TFA}^{-}\right)_{32}$ in $\mathrm{D}_{2} \mathrm{O}$. TFA anions have been omitted from the structure.

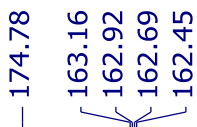

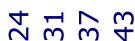

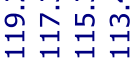

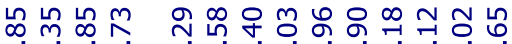
นิ่ மூ่
,

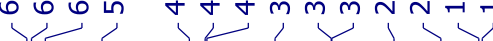

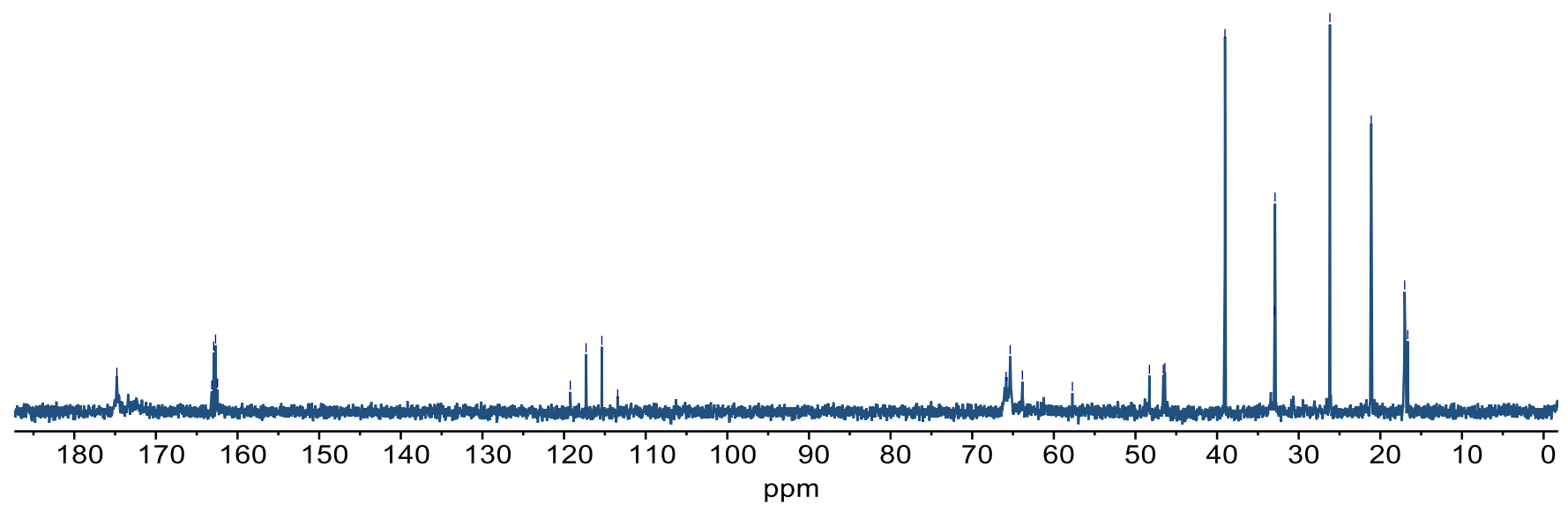

Figure S68. ${ }^{13} \mathrm{C}$ NMR of BnO-G5-(Lin- $\left.\mathrm{NH}_{3}{ }^{+} \mathrm{TFA}^{-}\right)_{32}$ in $\mathrm{D}_{2} \mathrm{O}$. 


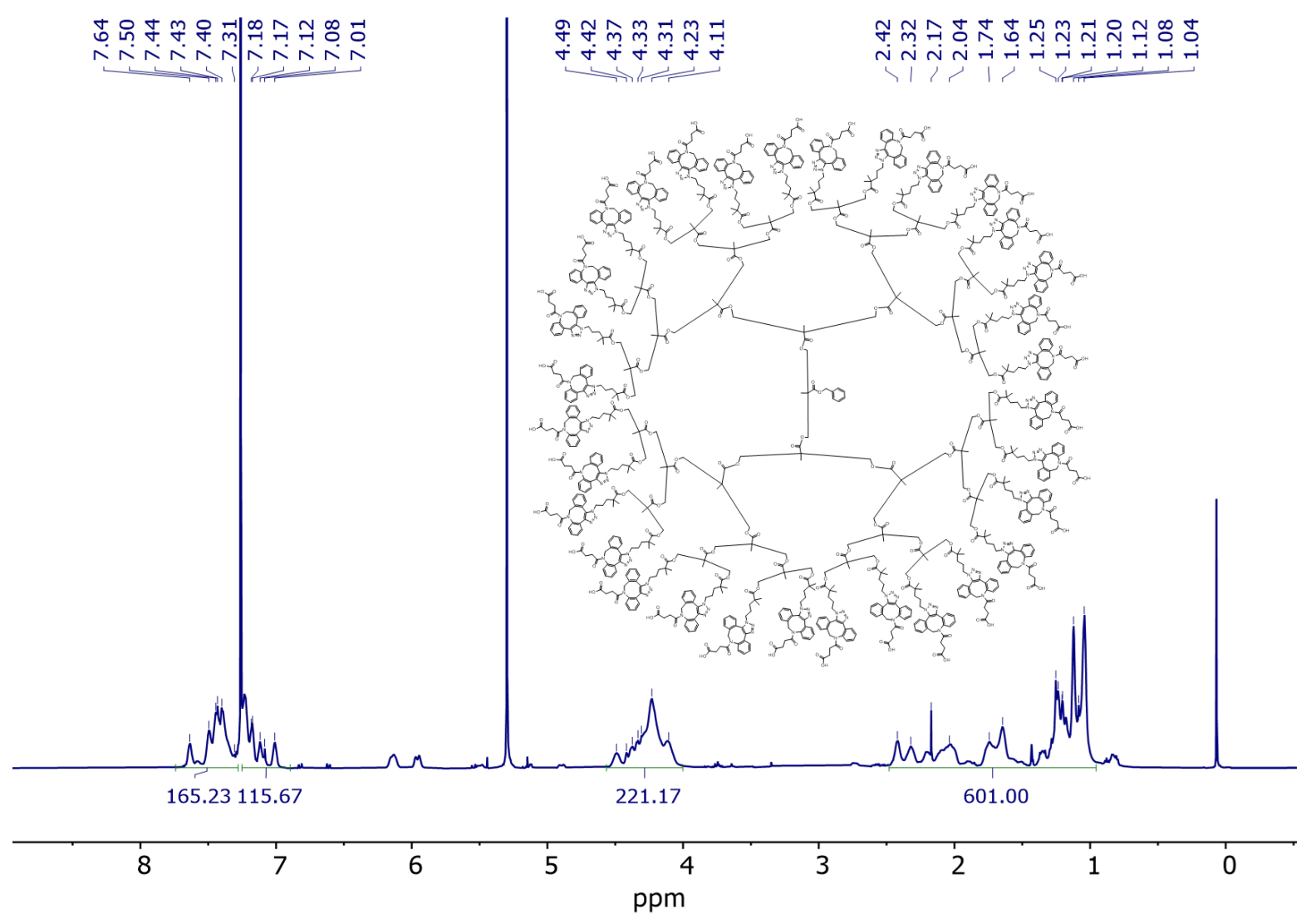

Figure S69. ${ }^{1} \mathrm{H}$ NMR of BnO-G5-(DBCO) $)_{32}$ in $\mathrm{CDCl}_{3}$.

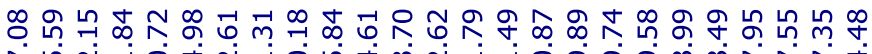

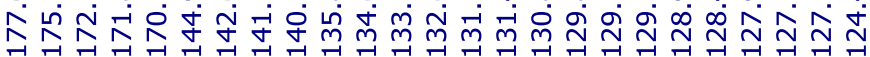

Figure S70. ${ }^{13} \mathrm{C}$ NMR of BnO-G5-(DBCO $)_{32}$ in $\mathrm{CDCl}_{3}$. 


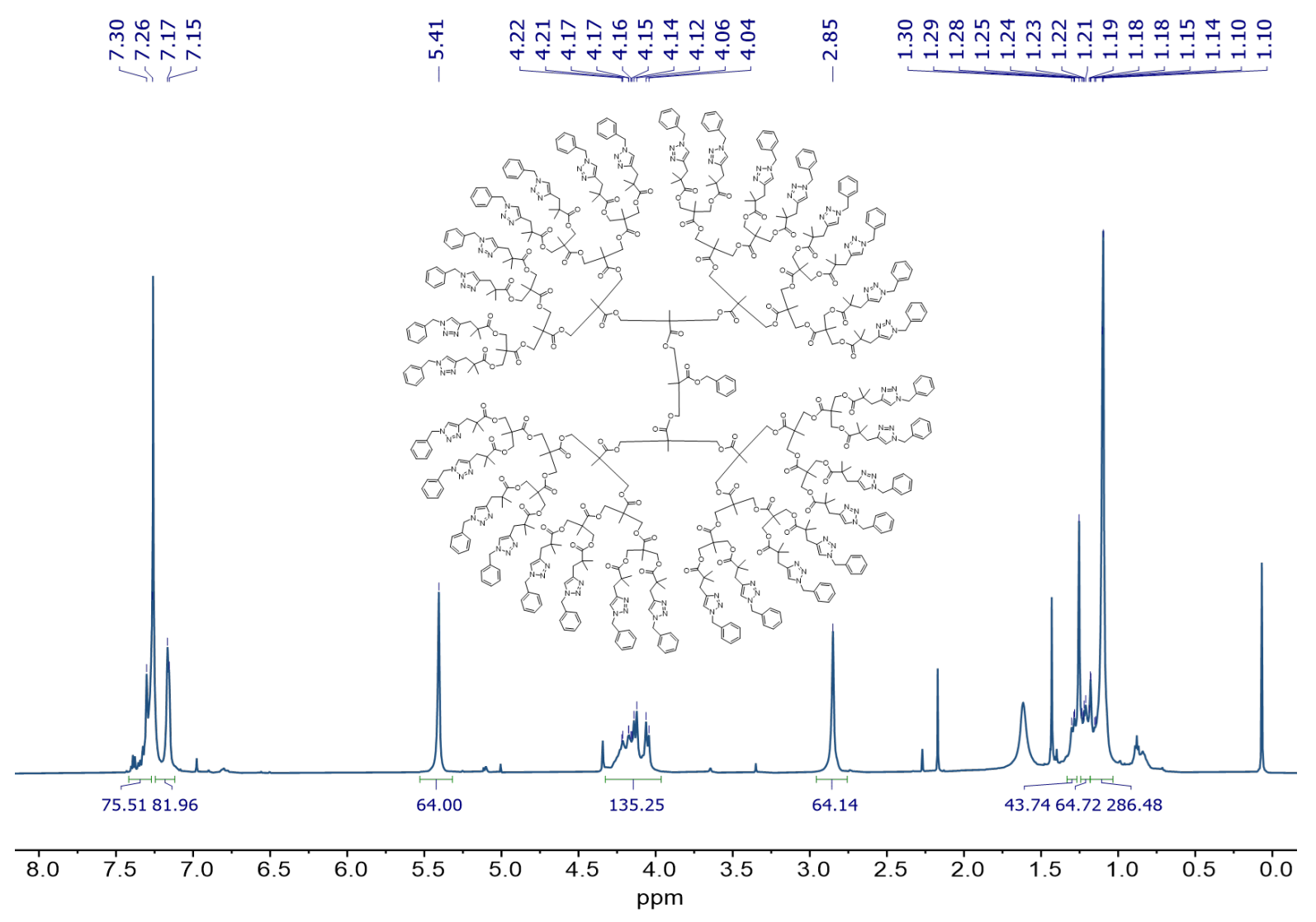

Figure S71. ${ }^{1} \mathrm{H}$ NMR of BnO-G5-(BzTr) $)_{32}$ in $\mathrm{CDCl}_{3}$.

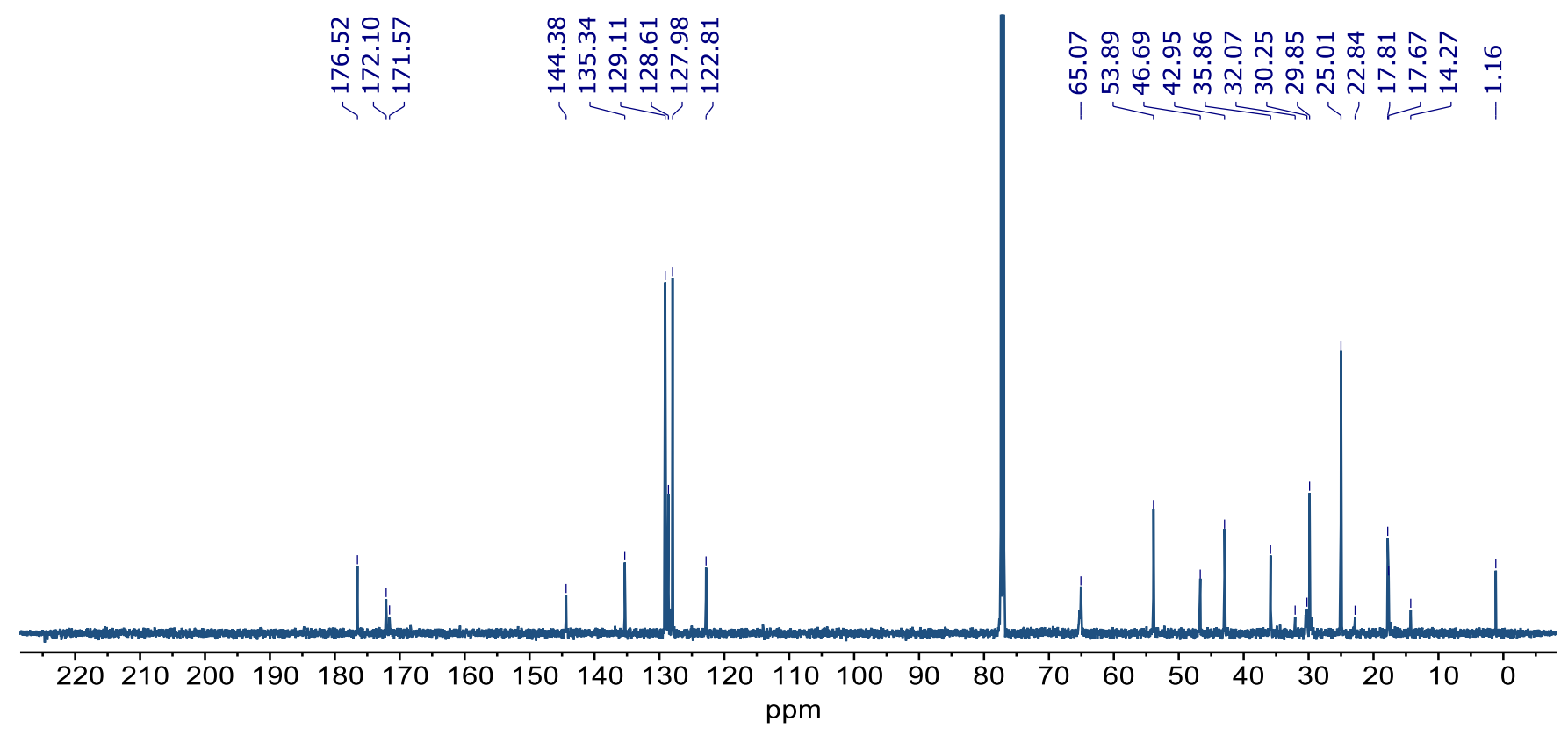

Figure S72. ${ }^{13} \mathrm{C}$ NMR of BnO-G5-(BzTr) $)_{32}$ in $\mathrm{CDCl}_{3}$. 


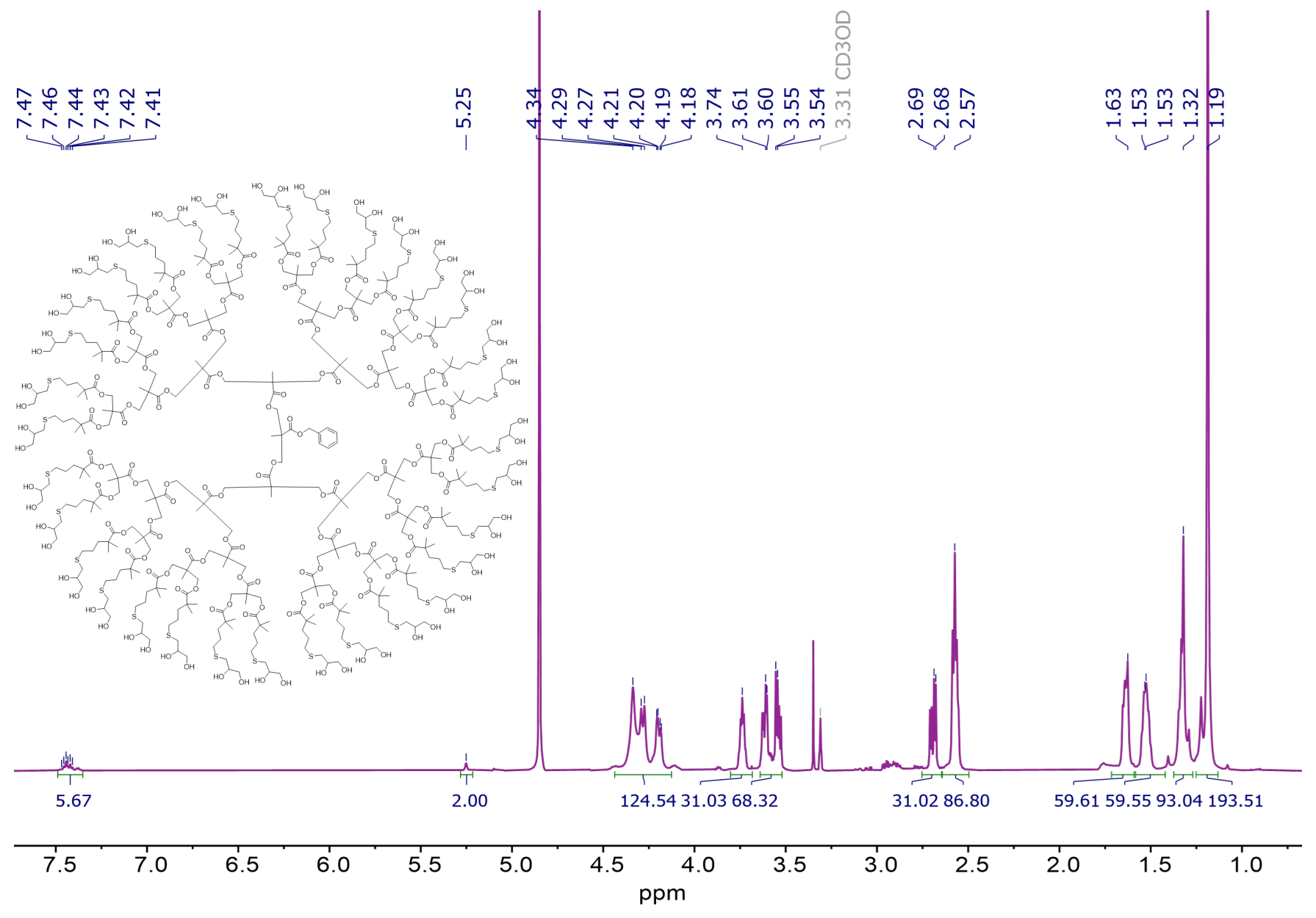

Figure S73. ${ }^{1} \mathrm{H}$ NMR of BnO-G5-(SR) 32 in MeOD.

in ํำ

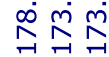

क्षें

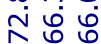

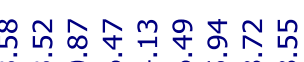

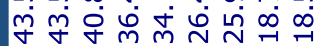

रण

$i \sqrt{1}$

年
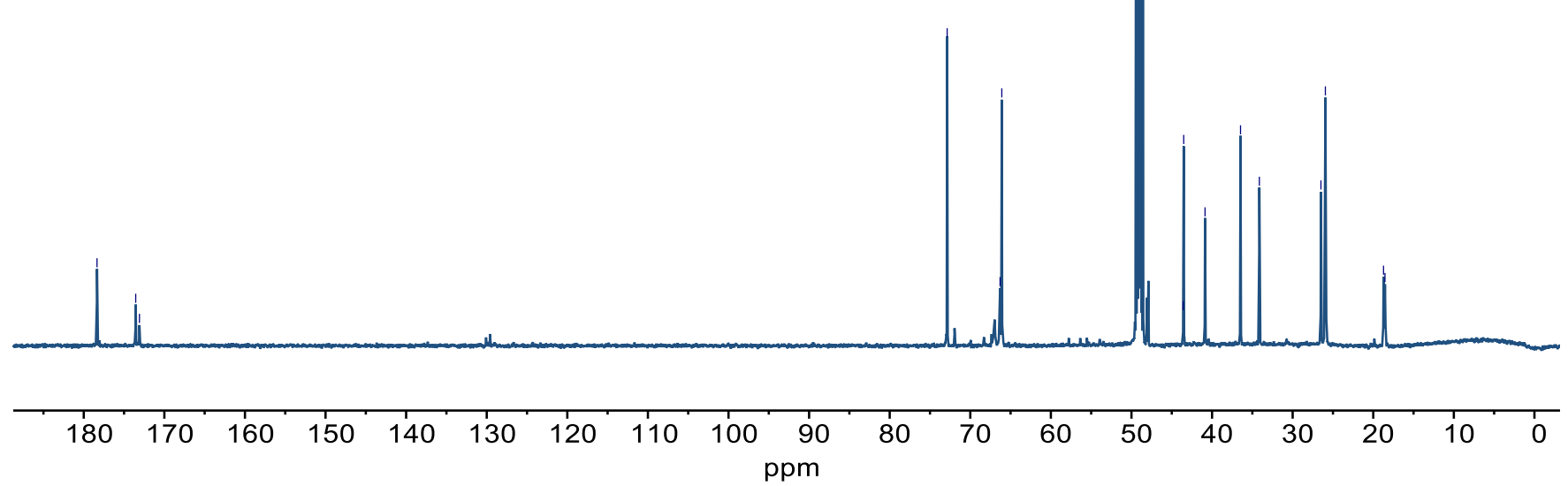

Figure S74. ${ }^{13} \mathrm{C}$ NMR of BnO-G5-(SR) 32 in MeOD. 


\section{Dendron MALDI Mass Spectra}

Alkene Dendrons

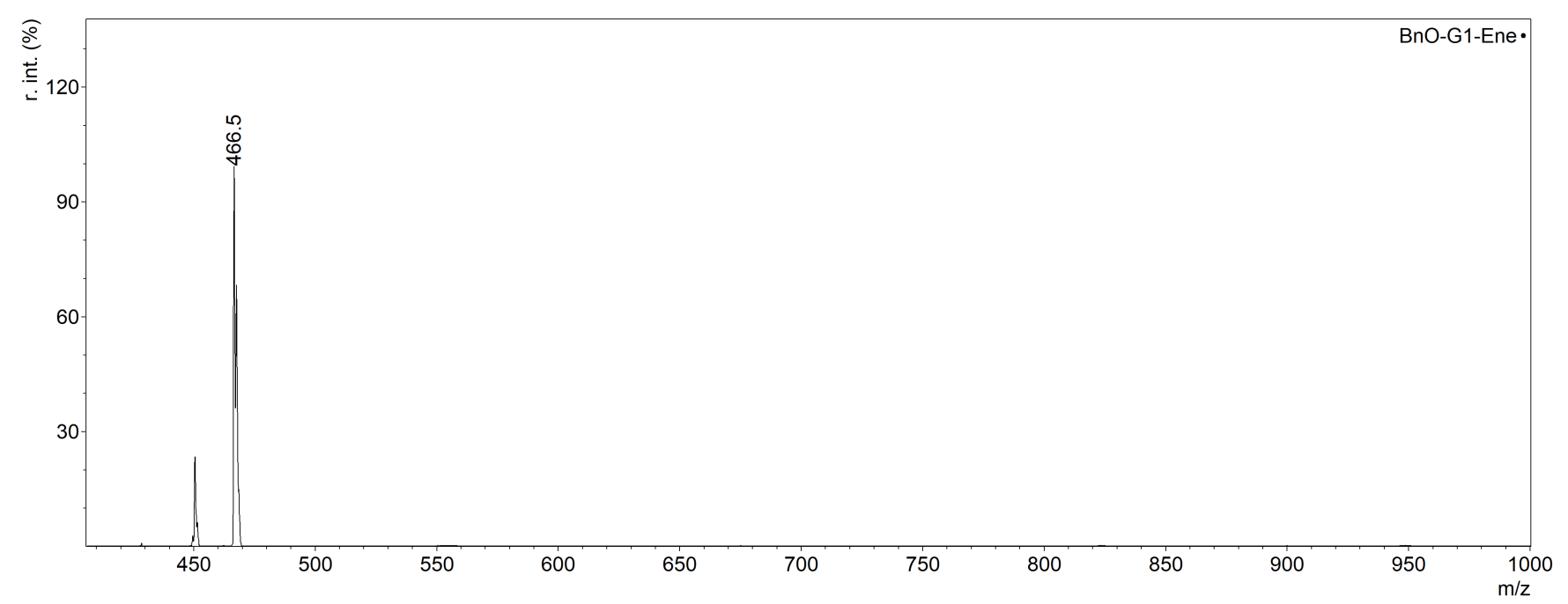

Figure S75. MALDI mass spectrum of BnO-G1-(ene) 2 .

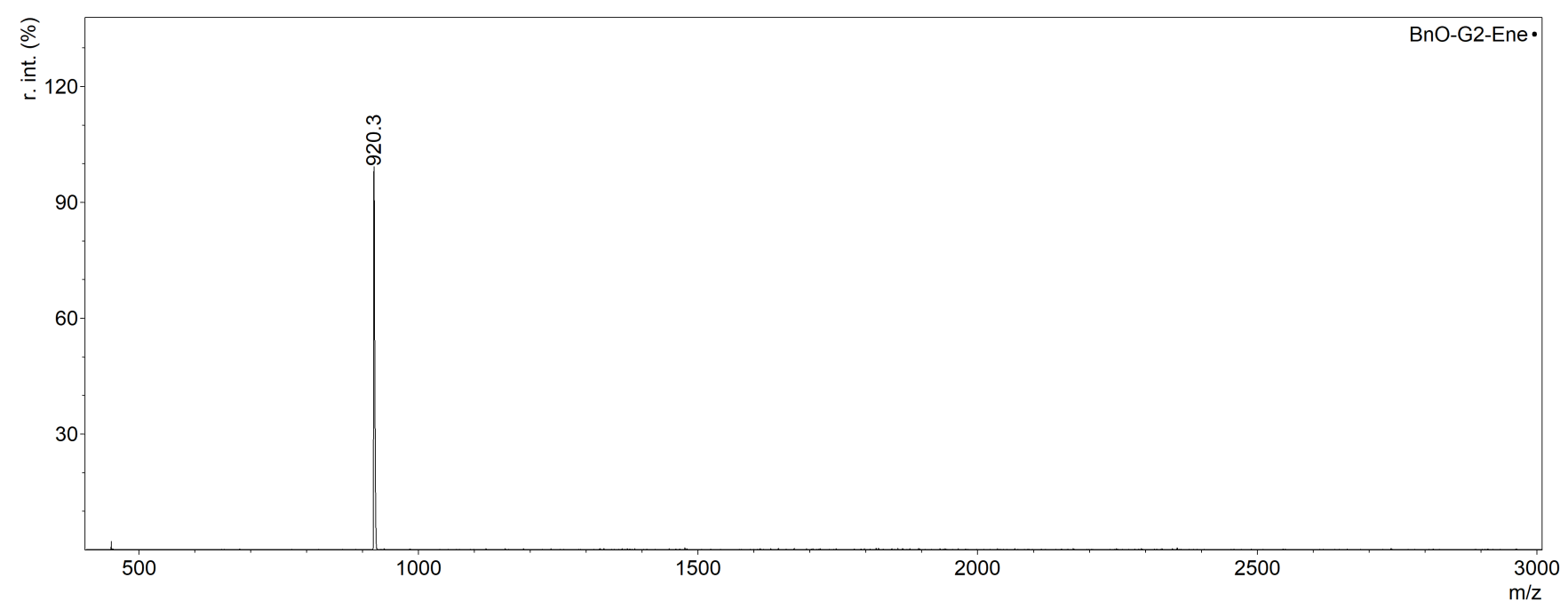

Figure S76. MALDI mass spectrum of BnO-G2-(ene) ${ }_{4}$. 


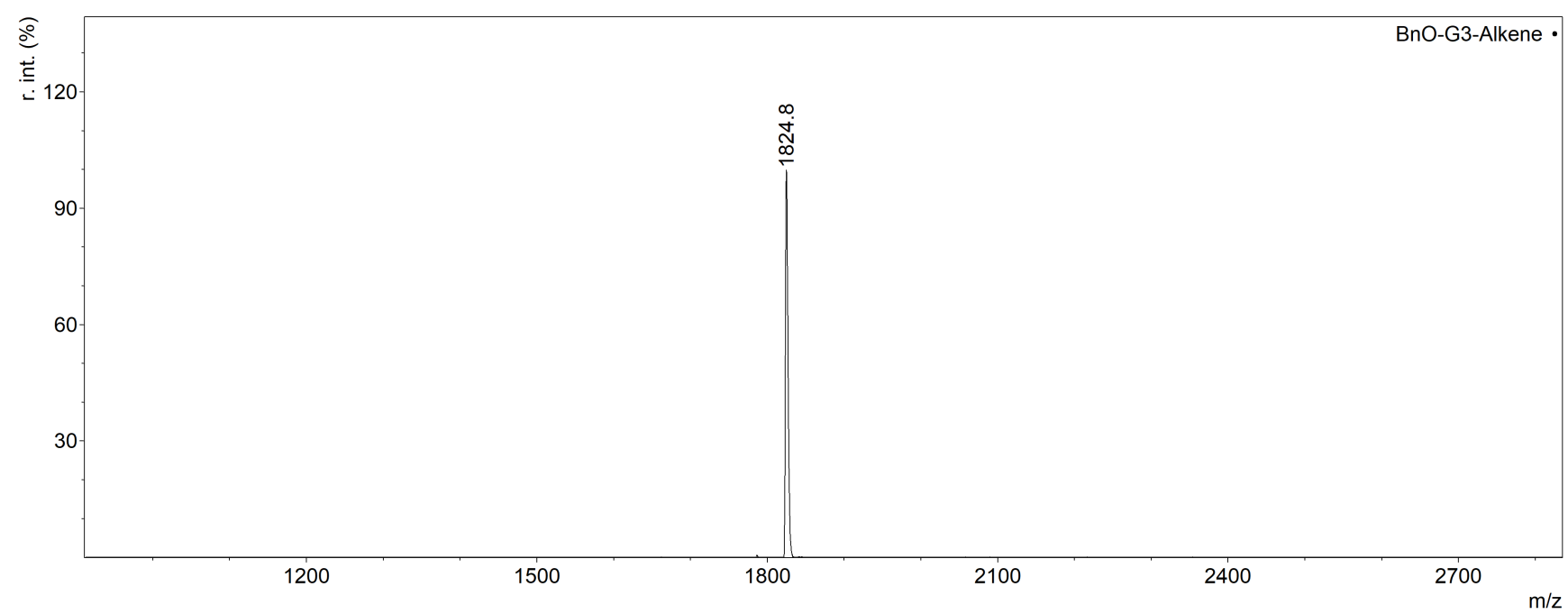

Figure S77. MALDI mass spectrum of BnO-G3-(ene) . $_{8}$

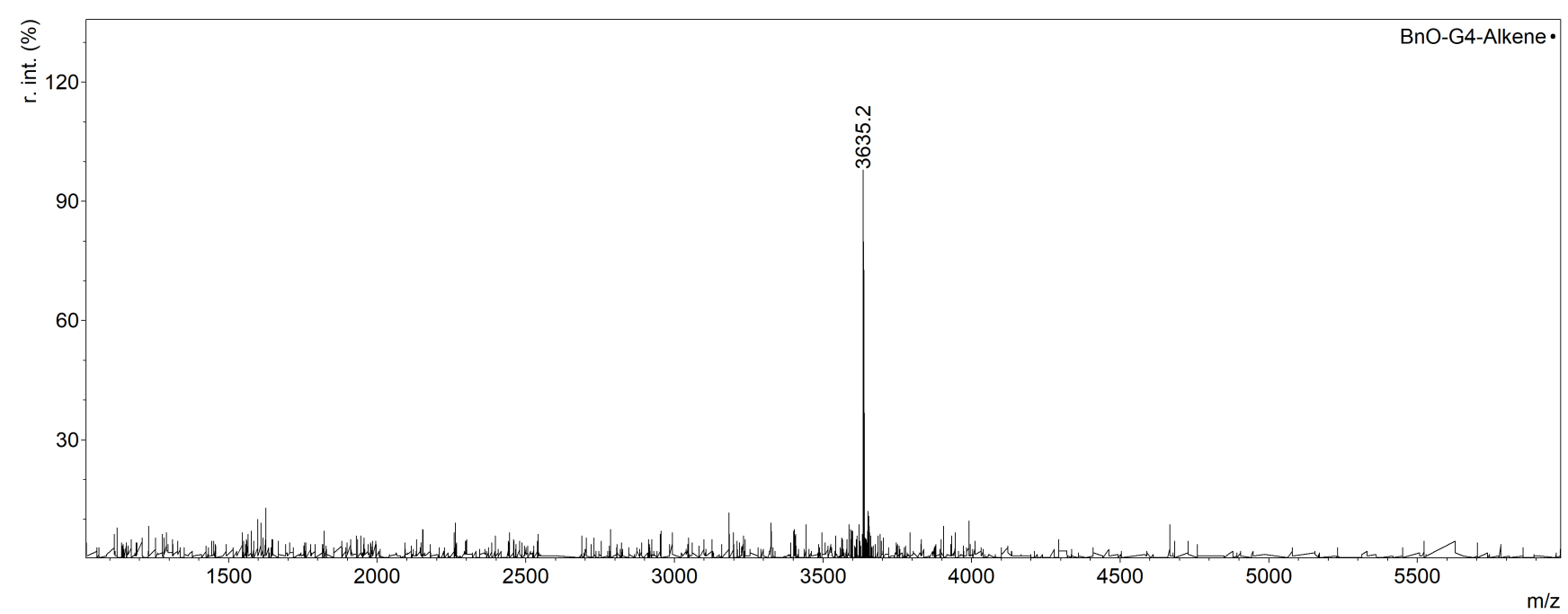

Figure S78. MALDI mass spectrum of BnO-G4-(ene) ${ }_{16}$.

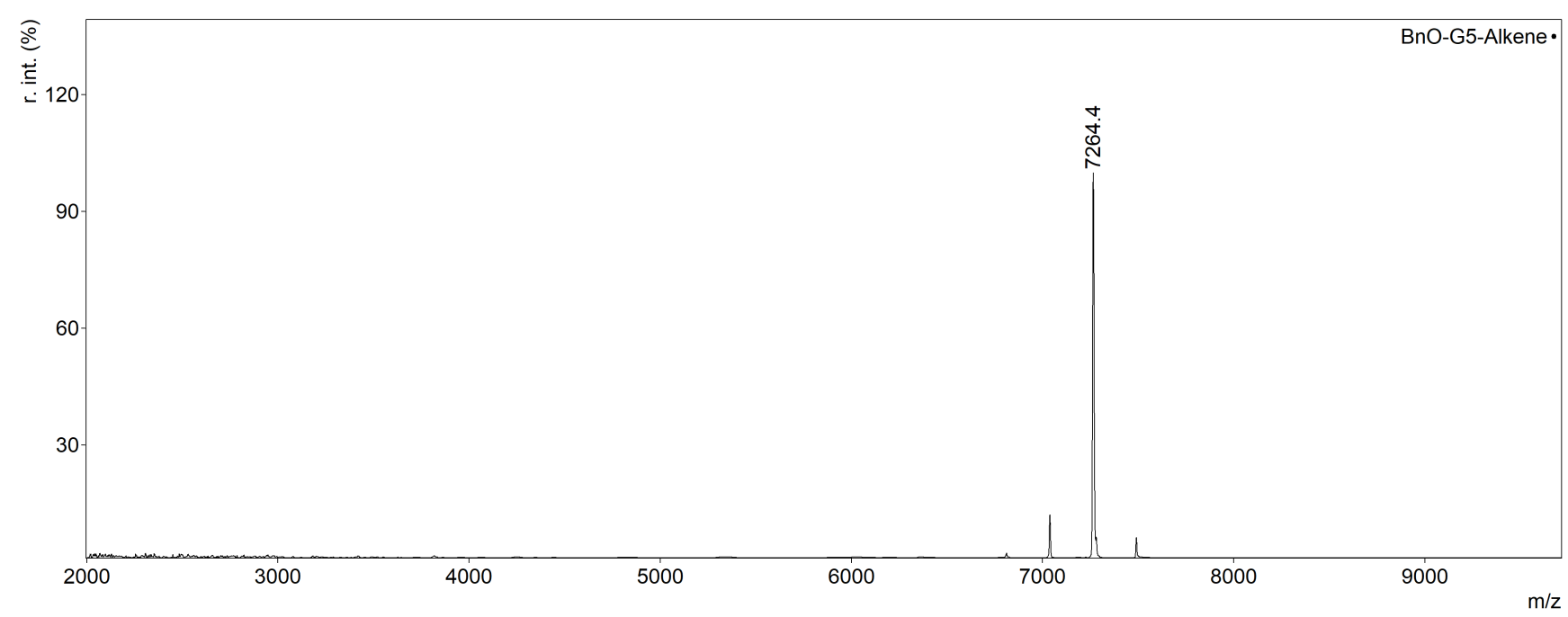

Figure S79. MALDI mass spectrum of BnO-G5-(ene) 32. $^{2}$ 


\section{Alkyne Dendrons}

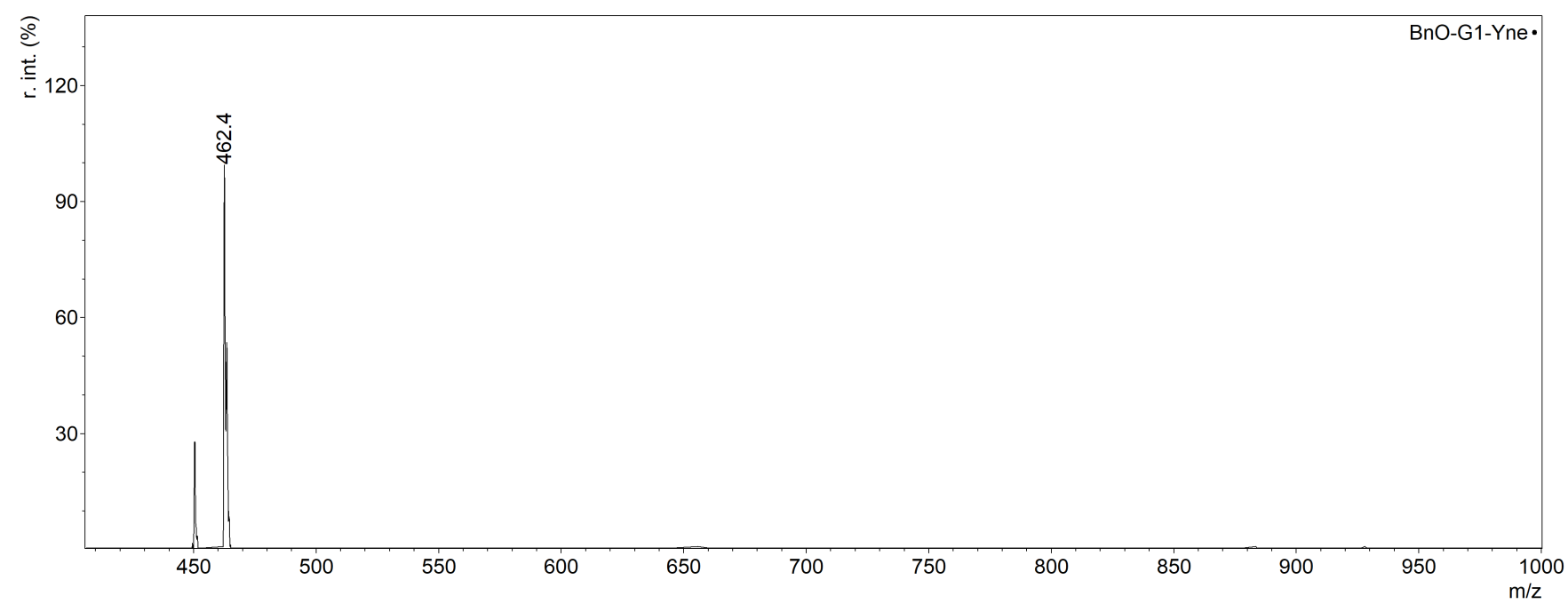

Figure S80. MALDI mass spectrum of BnO-G1-(yne)2.

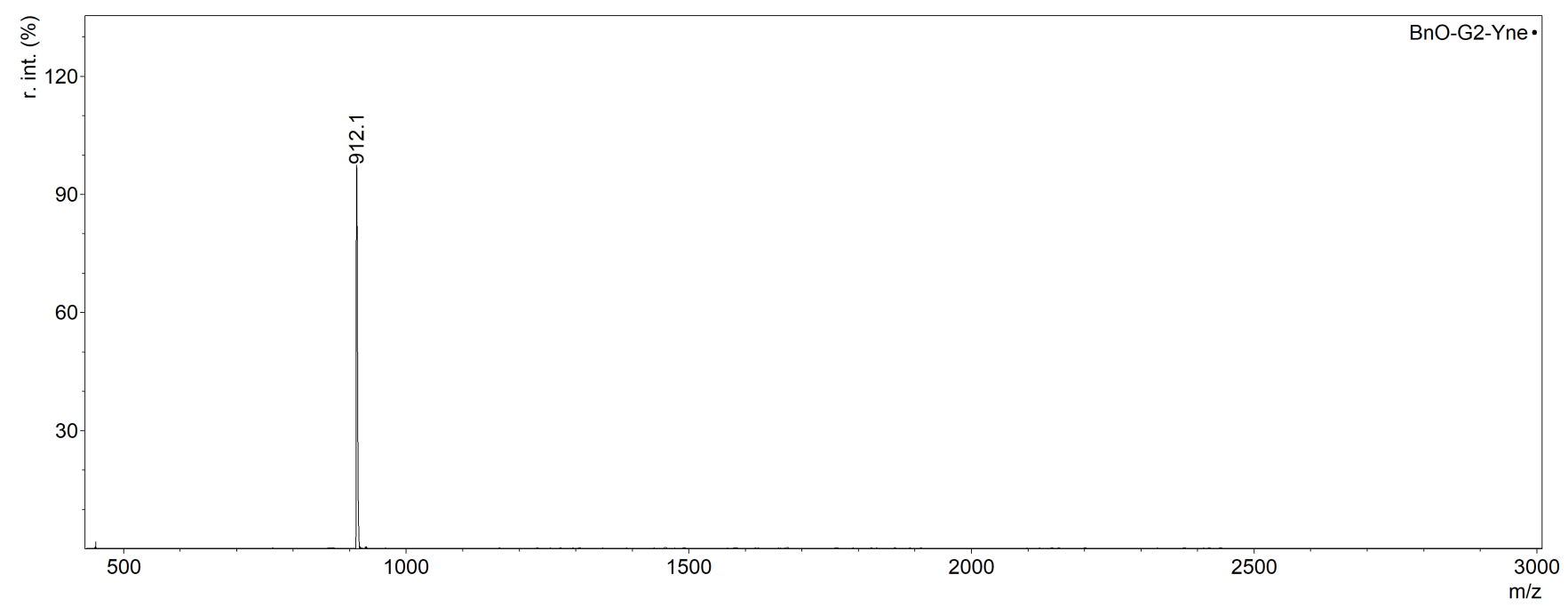

Figure S81. MALDI mass spectrum of BnO-G2-(yne) $)_{4}$.

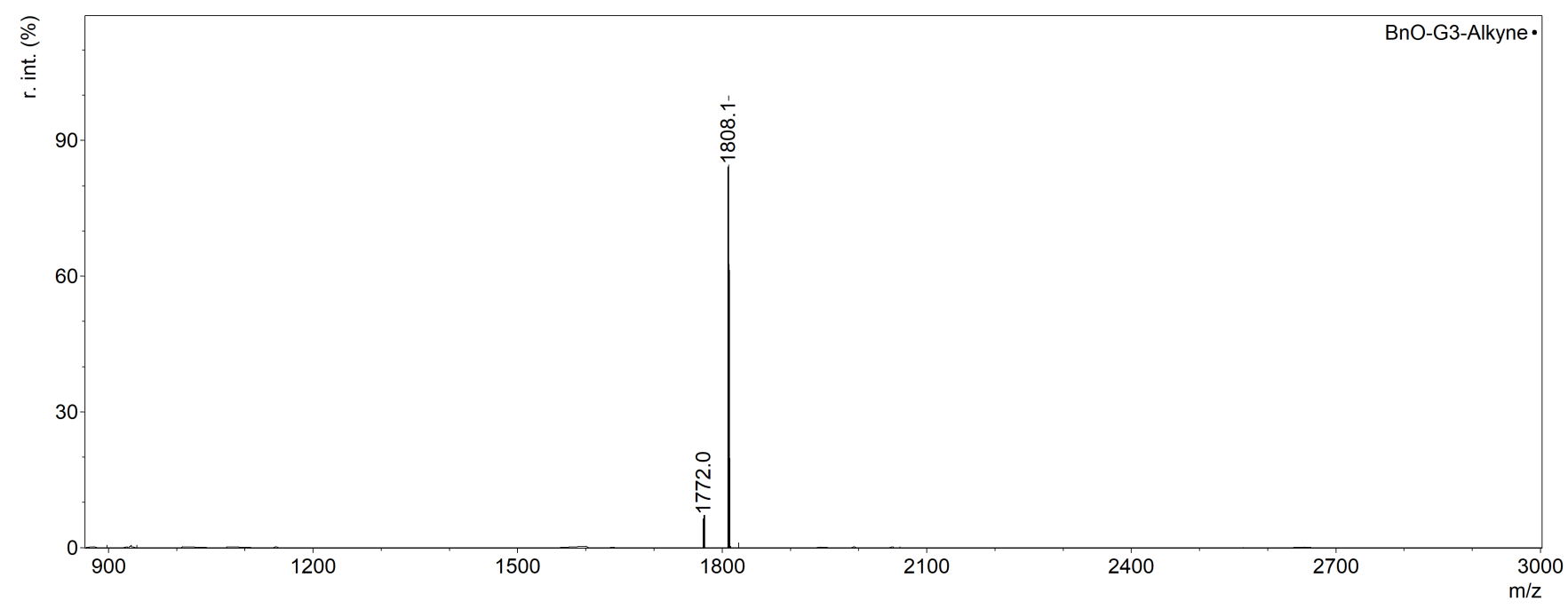

Figure S82. MALDI mass spectrum of BnO-G3-(yne)8. 


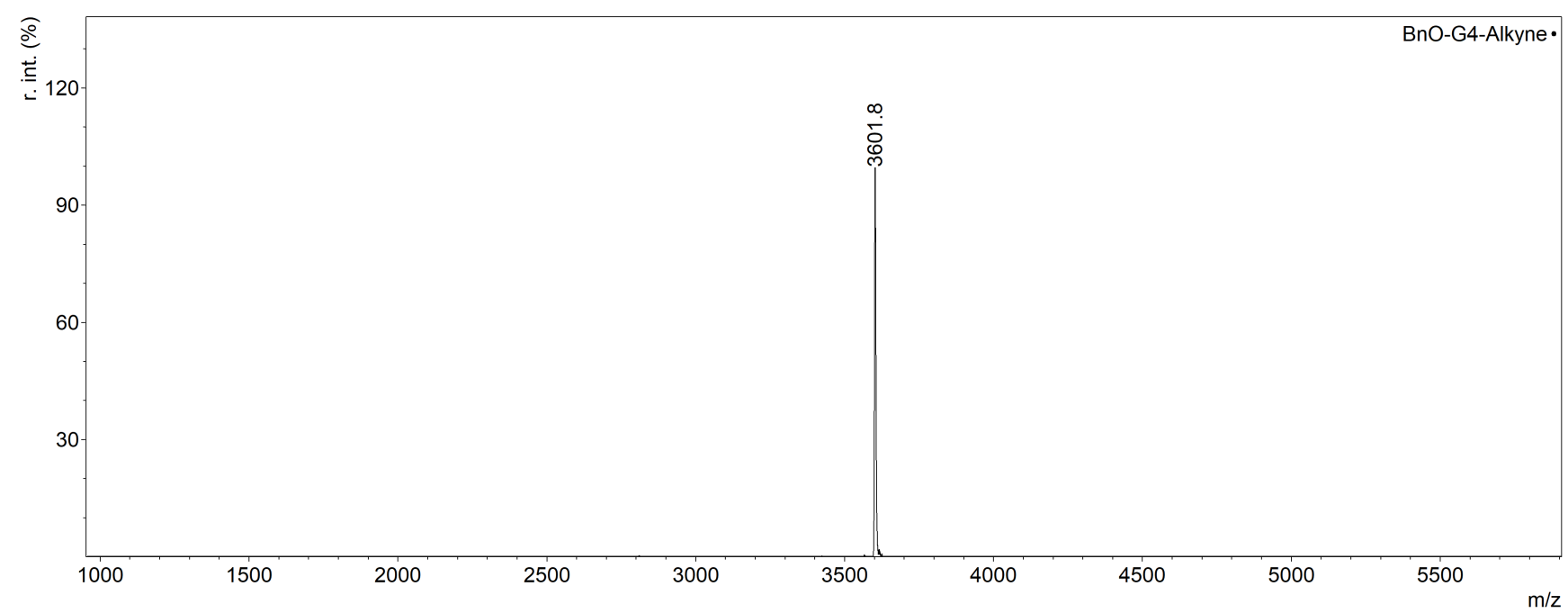

Figure S83. MALDI mass spectrum of BnO-G4-(yne) ${ }_{16}$

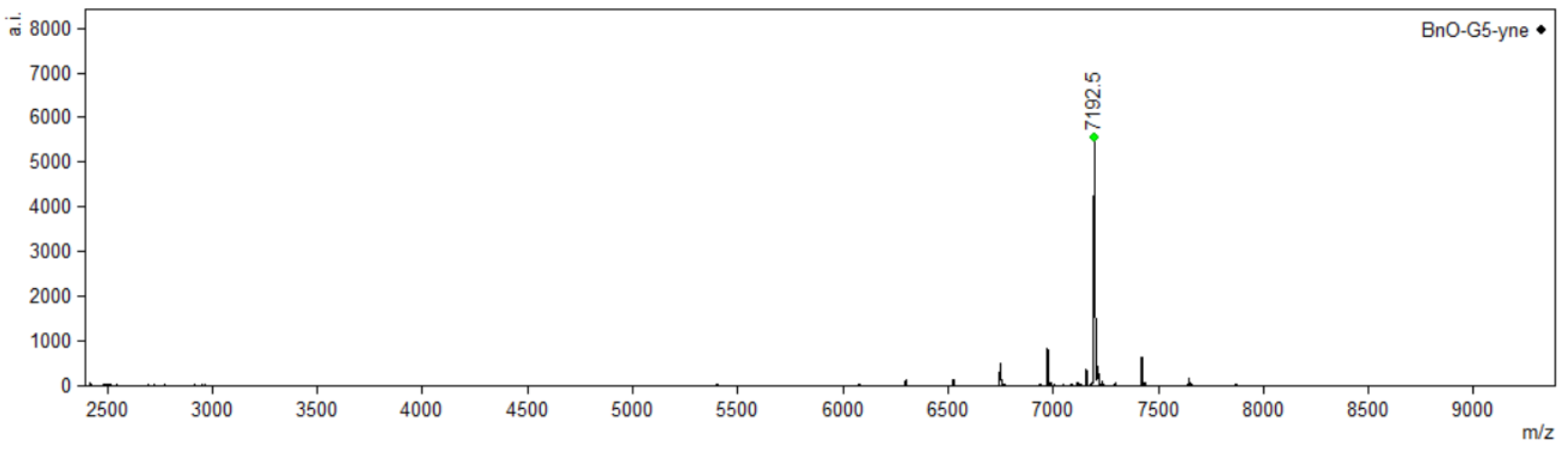

Figure S84. MALDI mass spectrum of BnO-G5-(yne) $)_{32}$

\section{Azide Dendrons}

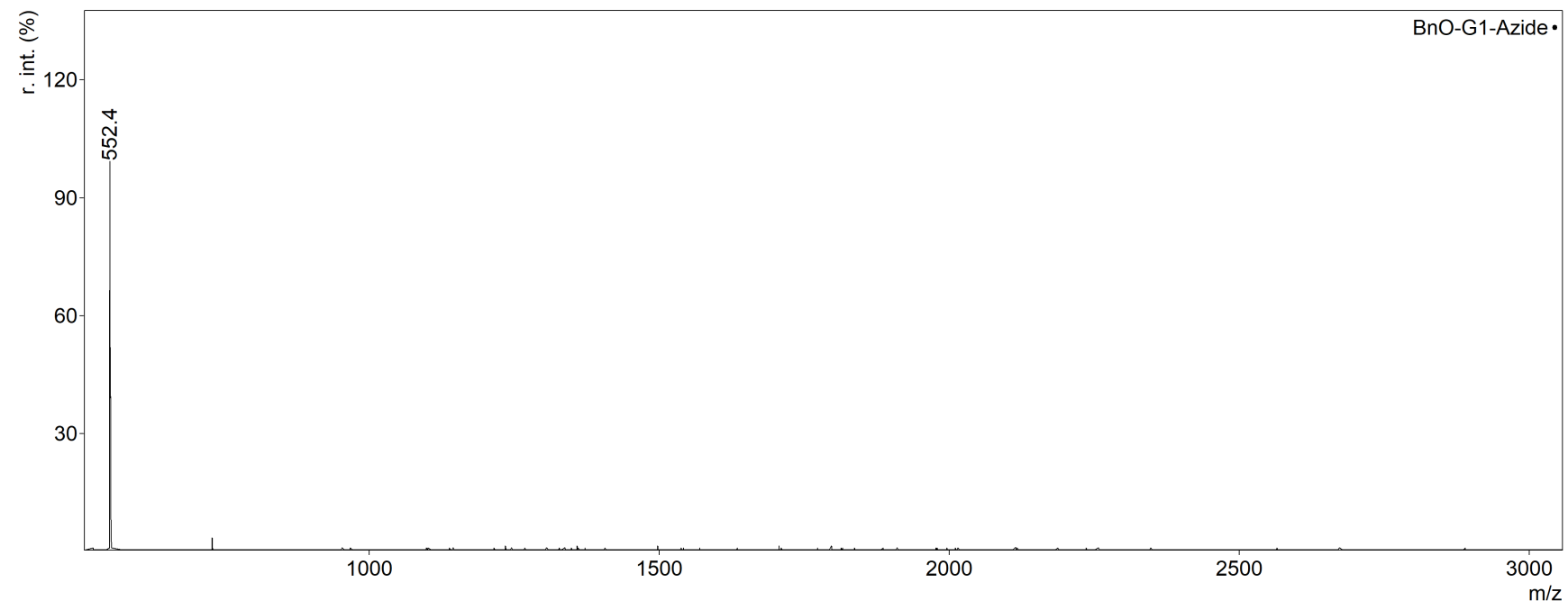

Figure S85. MALDI mass spectrum of BnO-G1-( $\left.\mathrm{N}_{3}\right)_{2}$. 


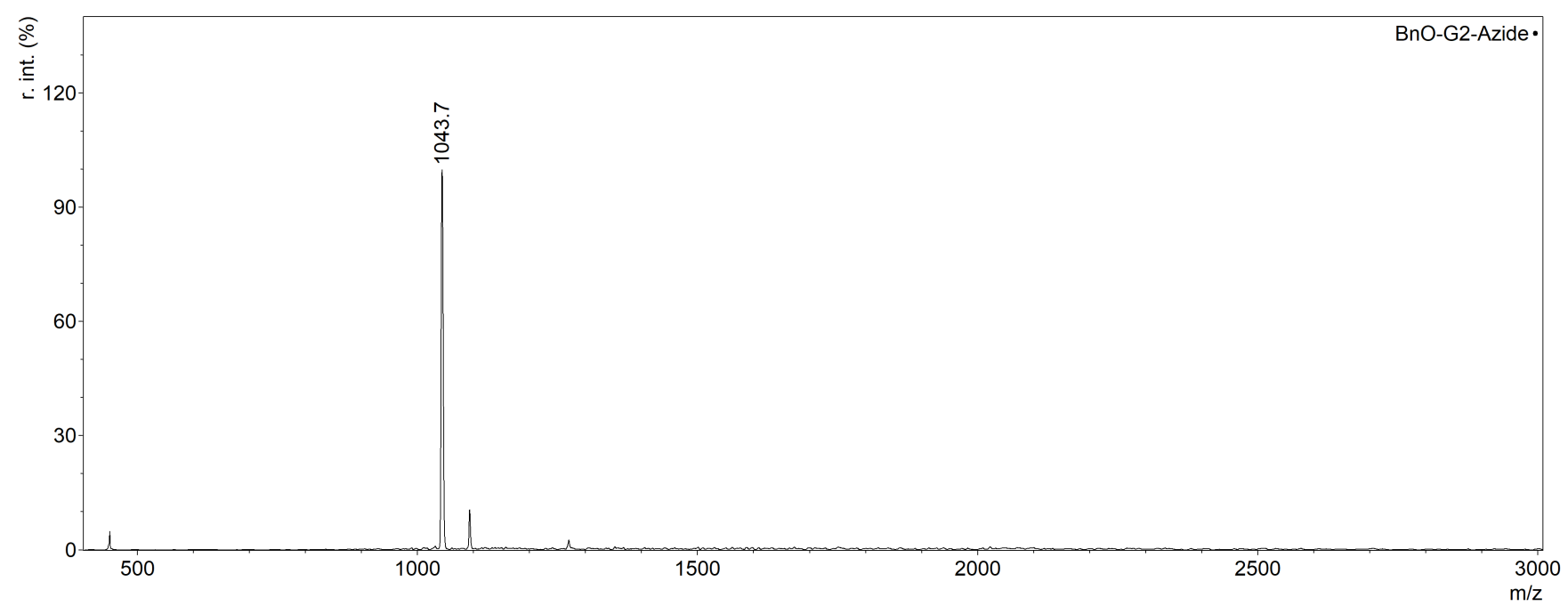

Figure S86. MALDI mass spectrum of BnO-G2-( $\left.\mathrm{N}_{3}\right)_{4}$.

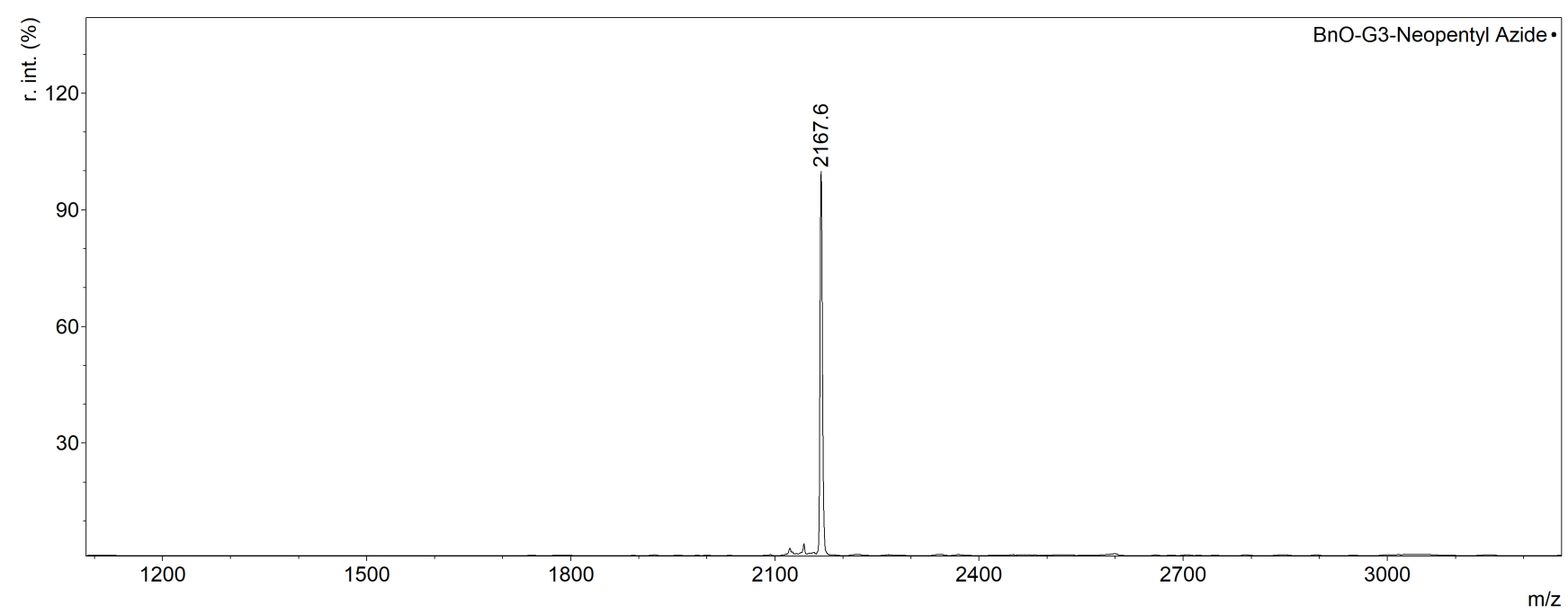

Figure S87. MALDI mass spectrum of BnO-G3-( $\left.\mathrm{N}_{3}\right)_{8}$.

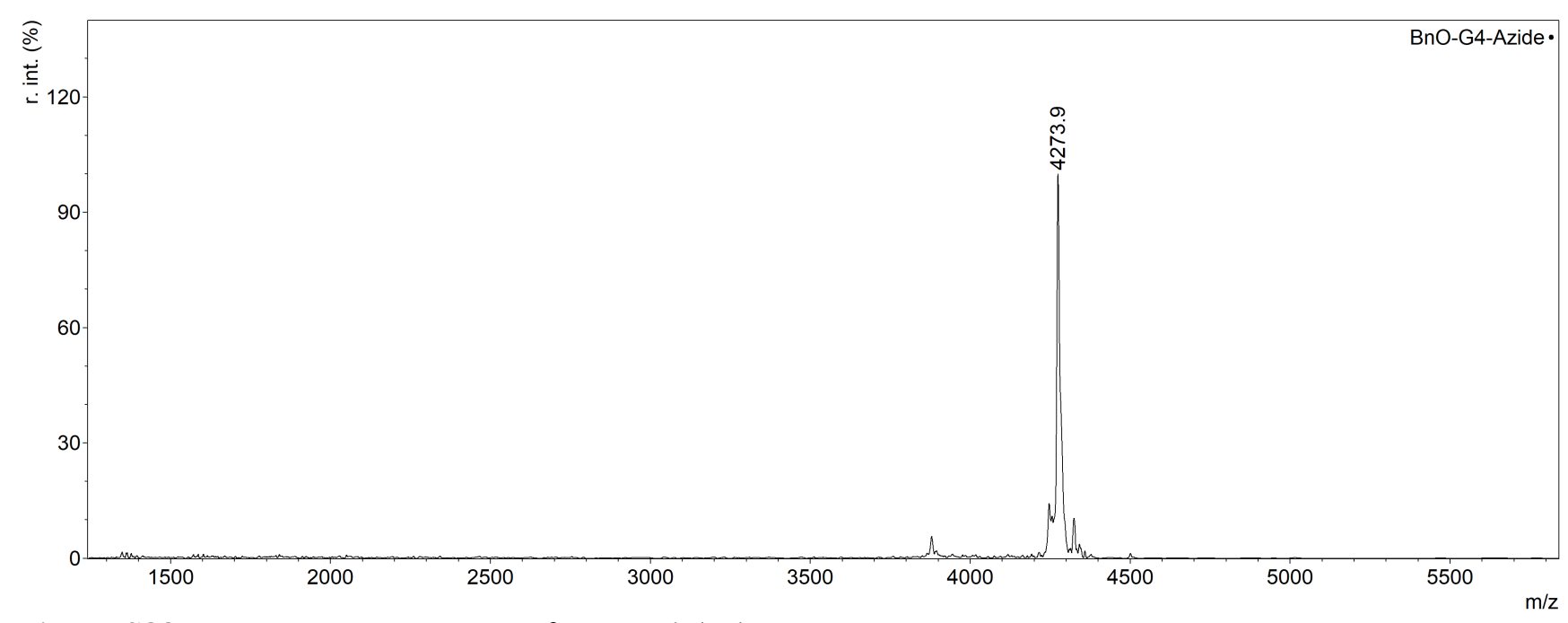

Figure S88. MALDI mass spectrum of BnO-G4-( $\left.\mathrm{N}_{3}\right)_{16}$. 


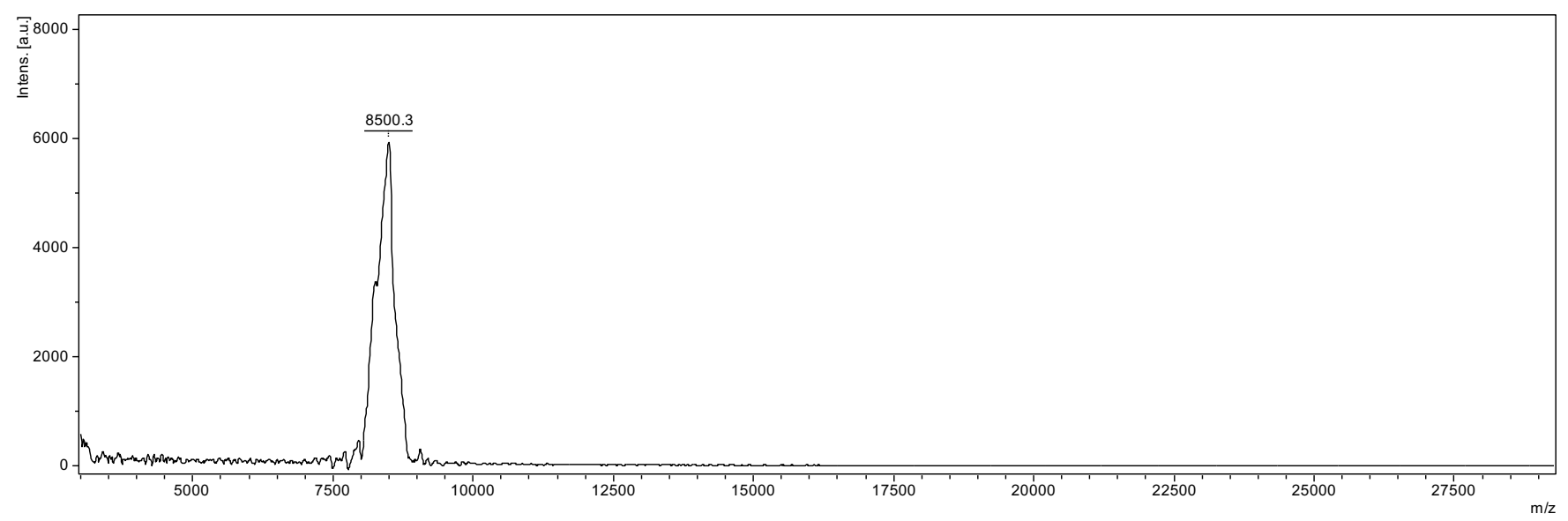

Figure S89. MALDI mass spectrum of BnO-G5-( $\left.\mathrm{N}_{3}\right)_{32}$.

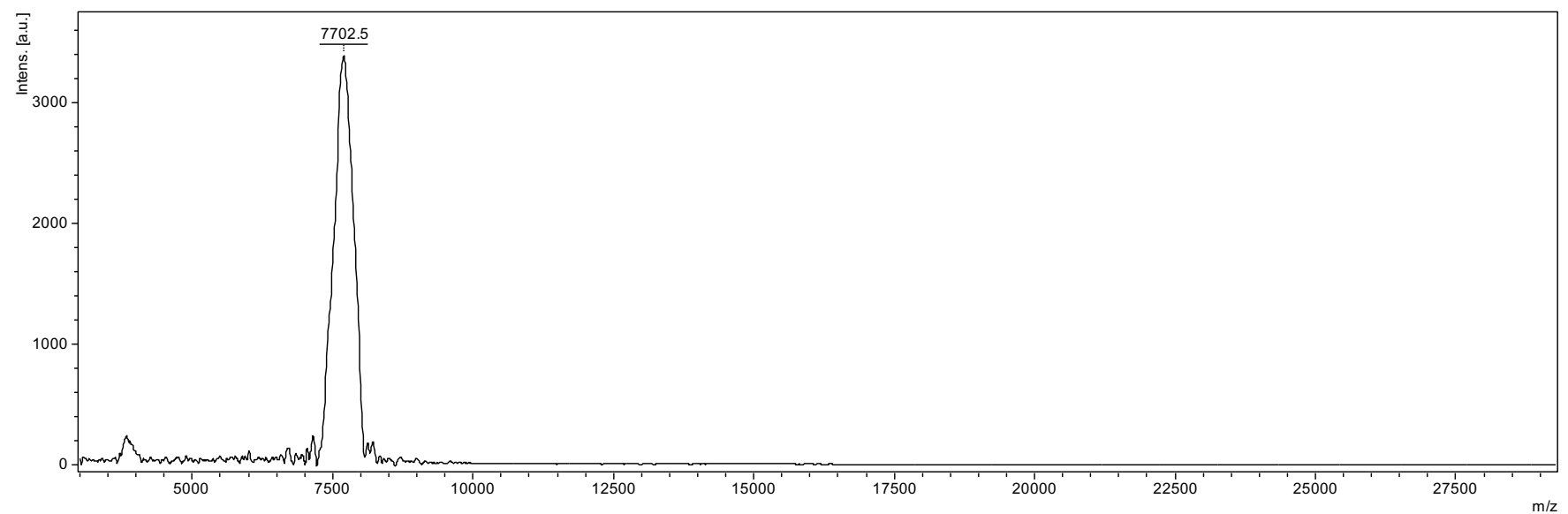

Figure S90. MALDI mass spectrum of BnO-G5-(Neo- $\left.\mathrm{NH}_{2}\right)_{32}$.

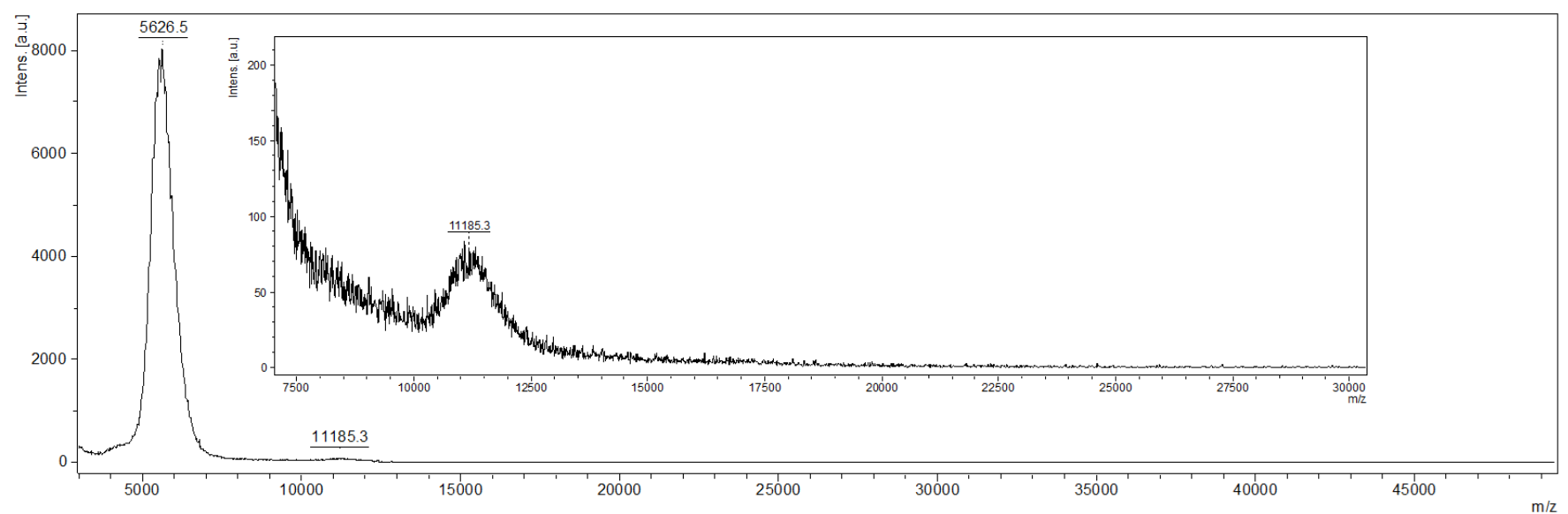

Figure S91. MALDI mass spectrum of BnO-G5-(Lin- $\left.\mathrm{NH}_{3}{ }^{+} \mathrm{TFA}^{-}\right)_{32}$ showing $[\mathrm{m}+\mathrm{H}]^{+}$and $[\mathrm{m}+2 \mathrm{H}]^{2+}$. Inset: magnification showing the $[\mathrm{m}+\mathrm{H}]^{+}$species. 


\section{Click-reacted Dendrons}

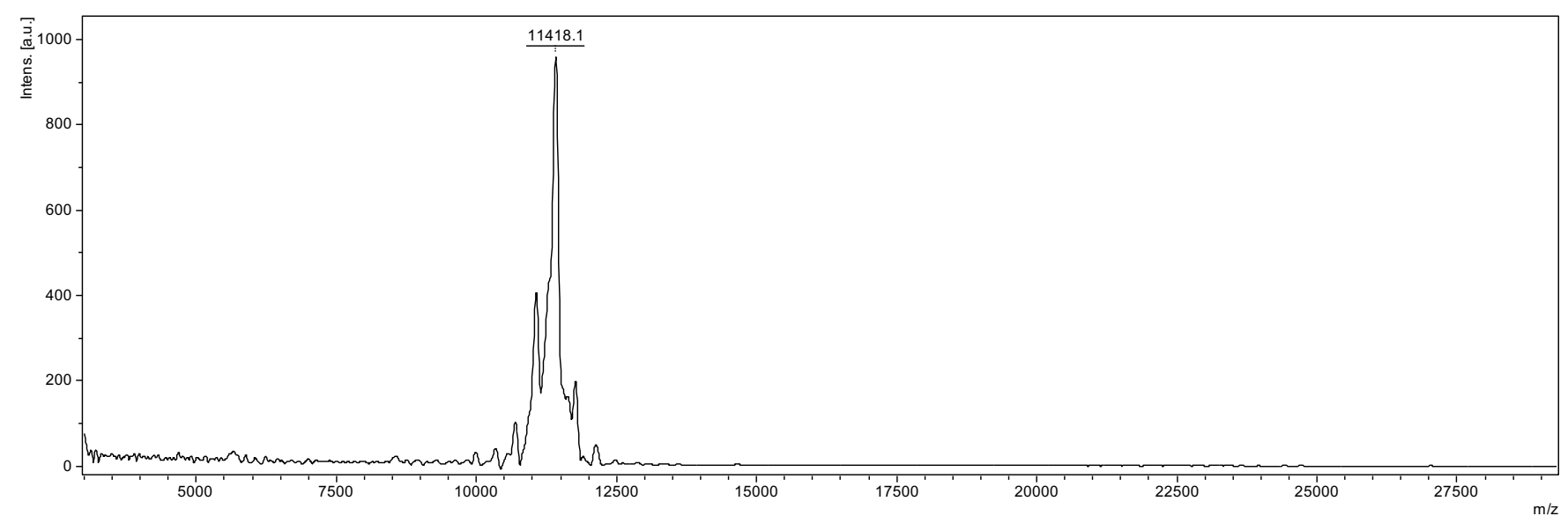

Figure S92. MALDI mass spectrum of BnO-G5-(BzTr) ${ }_{32}$, the CuAAC product of BnO-G5-(yne) 32 .

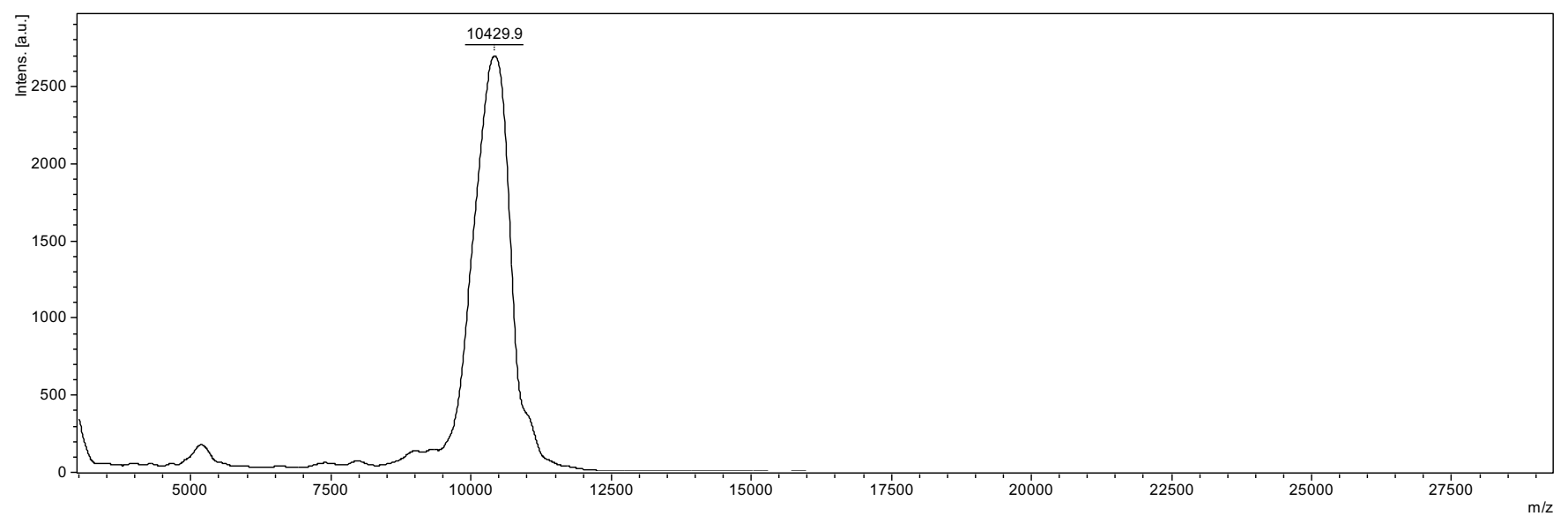

Figure S93. MALDI mass spectrum of BnO-G5-(SR) ${ }_{32}$, the thiol-ene click product of BnO-G5-(ene) $)_{32}$.

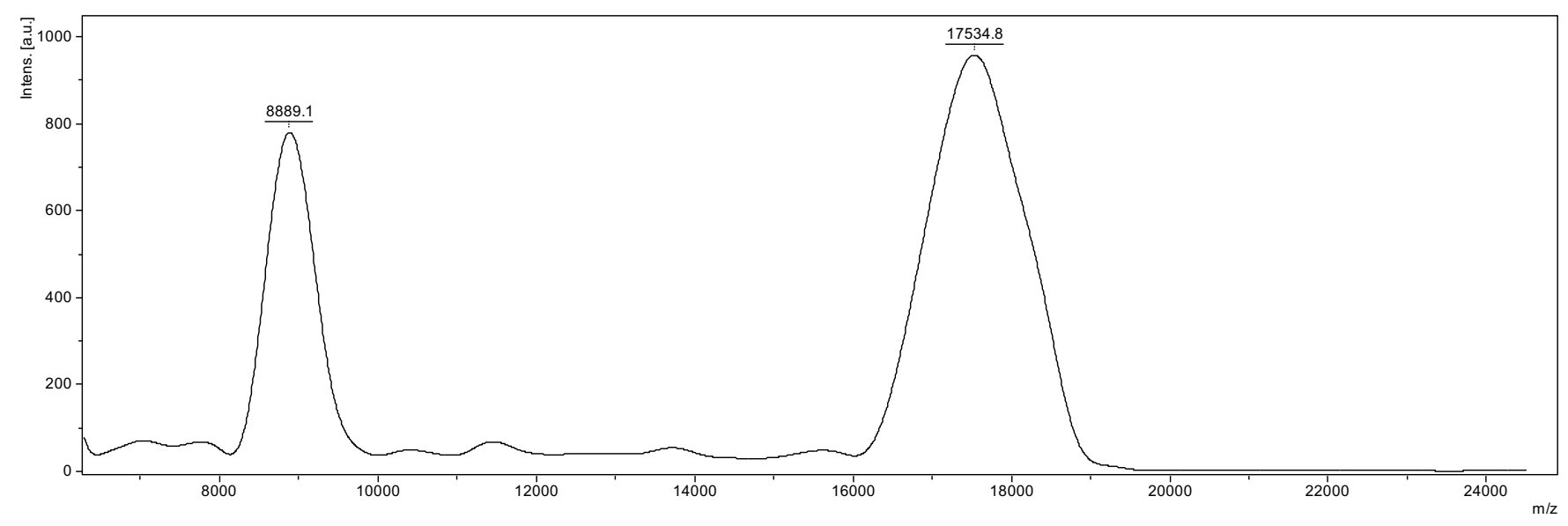

Figure S94. MALDI mass spectrum of BnO-G5-(DBCO) ${ }_{32}$, the SPAAC click product of BnO-G5-(N $)_{32}$. 


\section{Works Cited}

(1) Kayahara, E.; Yamada, H.; Yamago, S. Generation of Carbanions through Stibine-Metal and BismuthineMetal Exchange Reactions and Its Applications to Precision Synthesis of $\omega$-End-Functionalized Polymers. Chem. - A Eur. J. 2011, 17 (19), 5272-5280. https://doi.org/10.1002/chem.201100265.

(2) Cottrell, I. F.; Cowley, A. R.; Croft, L. J.; Hymns, L.; Moloney, M. G.; Nettleton, E. J.; Kirsty Smithies, H.; Thompson, A. L. Acyloxylactonisations Mediated by Lead Tetracarboxylates. Tetrahedron 2009, 65 (12), 2537-2550. https://doi.org/10.1016/j.tet.2009.01.042.

(3) Ramsay, W. J.; Bell, N. A. W.; Qing, Y.; Bayley, H. Single-Molecule Observation of the Intermediates in a Catalytic Cycle. J. Am. Chem. Soc. 2018, 140 (50), 17538-17546. https://doi.org/10.1021/jacs.8b09282.

(4) Mueller, R.; Yang, J.; Duan, C.; Pop, E.; Zhang, L. H.; Huang, T.-B.; Denisenko, A.; Denisko, O. V.; Oniciu, D. C.; Bisgaier, C. L.; Pape, M. E.; Freiman, C. D.; Goetz, B.; Cramer, C. T.; Hopson, K. L.; Dasseux, J.-L. H. Long Hydrocarbon Chain Ether Diols and Ether Diacids That Favorably Alter Lipid Disorders in Vivo. J. Med. Chem. 2004, 47 (21), 5183-5197. https://doi.org/10.1021/jm0400395.

(5) García-Gallego, S.; Hult, D.; Olsson, J. V.; Malkoch, M. Fluoride-Promoted Esterification with ImidazolideActivated Compounds: A Modular and Sustainable Approach to Dendrimers. Angew. Chemie - Int. Ed. 2015, 54 (8), 2416-2419. https://doi.org/10.1002/anie.201411370.

(6) Ihre, H.; Hult, A.; Fréchet, J. M. J.; Gitsov, I. Double-Stage Convergent Approach for the Synthesis of Functionalized Dendritic Aliphatic Polyesters Based on 2,2-Bis(Hydroxymethyl)Propionic Acid. Macromolecules 1998, 31 (13), 4061-4068. https://doi.org/10.1021/ma9718762. 